Selected Annotated

Bibliography of

Minor-Element Content of

Marine Black Shales and

Related Sedimentary Rocks,

$1930-65$

GEOLOGICAL SURVEY BULLETIN 1293

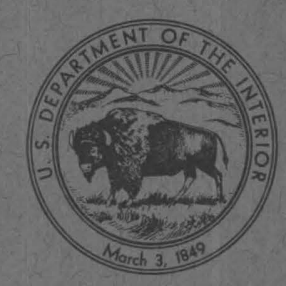


1.

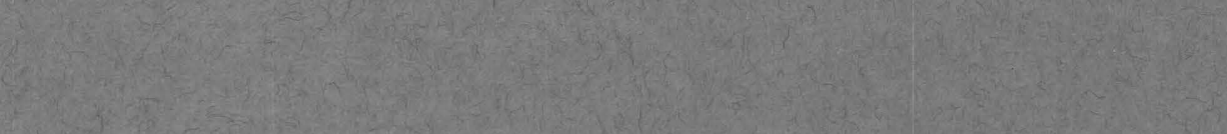
1. 30 .

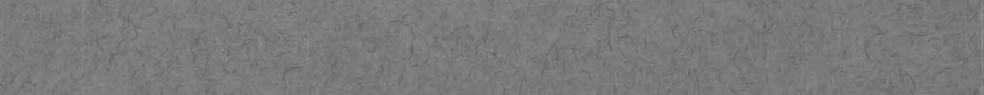

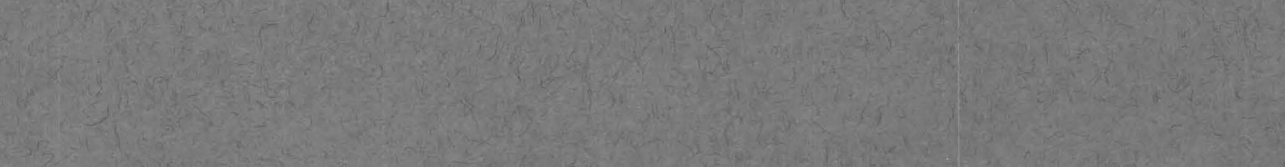
-

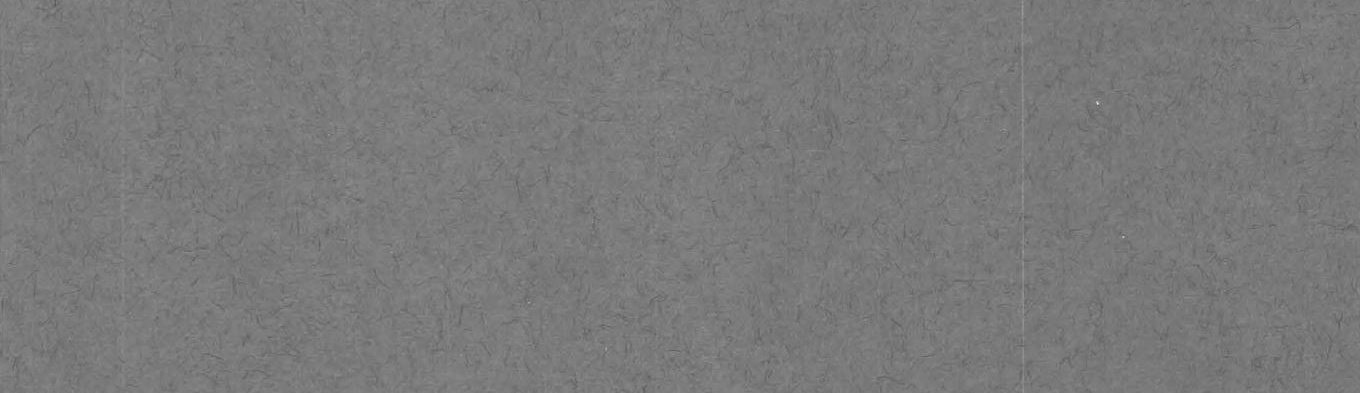
15.

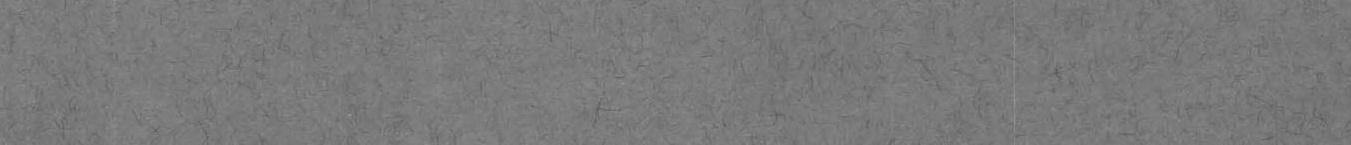

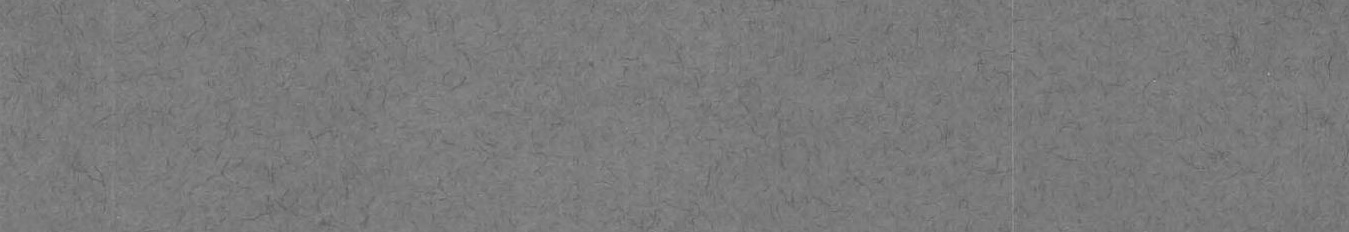

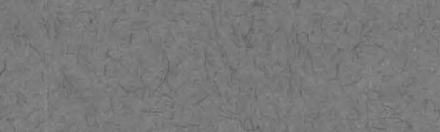

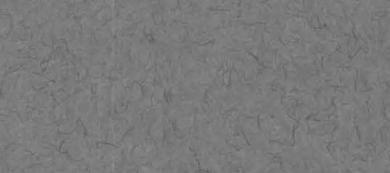
2.

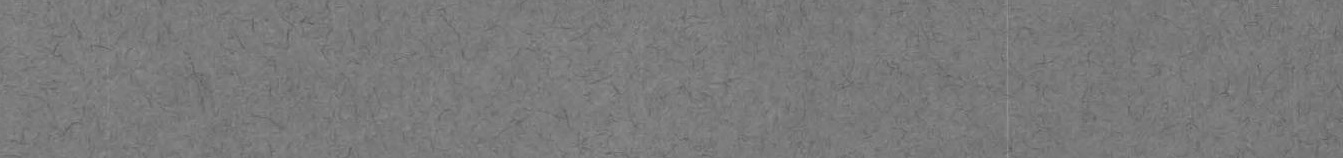

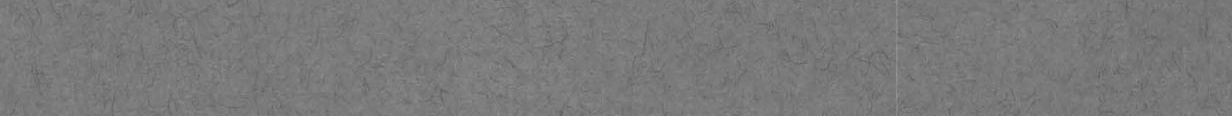
4. 4. 20.0

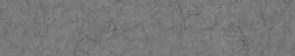

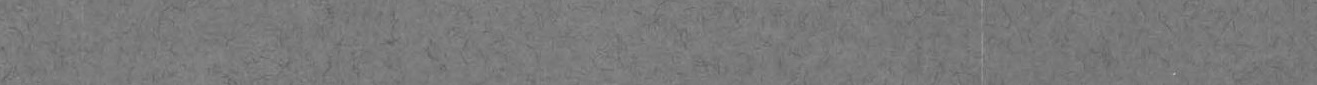

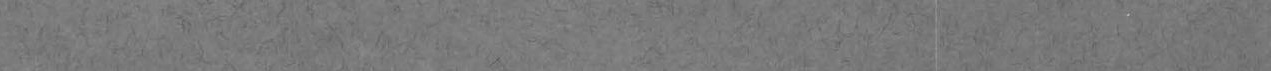
S

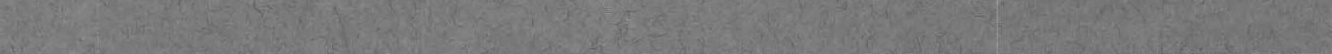




\section{Selected Annotated}

\section{Bibliography of}

Minor-Element Content of

\section{Marine Black Shales and}

\section{Related Sedimentary Rocks,}

$1930-65$

By ELIZABETH B. TOURTELOT

G E O L O G I C A L U R V E Y B U L L E T I N 1293

Includes abstracts of about 375 selected articles published during 1930-65 pertaining to worldwide occurrences of black shale.

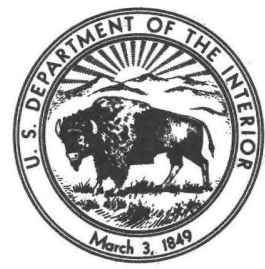




\section{UNITED STATES DEPARTMENT OF THE INTERIOR WALTER J. HICKEL, Secretary}

\section{GEOLOGICAL SURVEY}

William T. Pecora, Director

Library of Congress catalog-card No. 75-604512 


\section{CONTENTS}

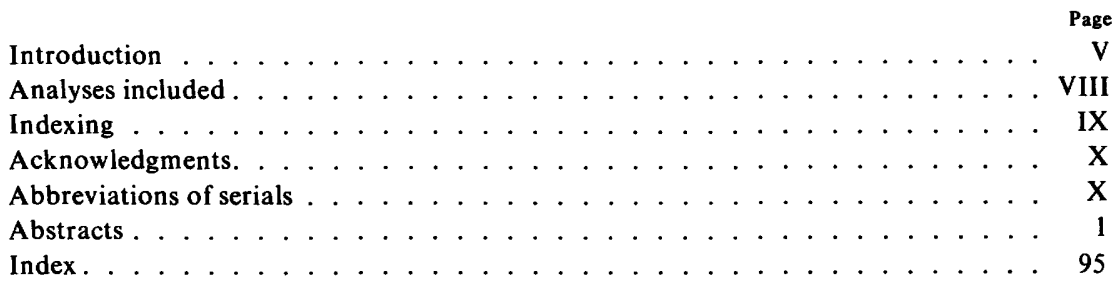





\title{
SELECTED ANNOTATED BIBLIOGRAPHY OF MINOR-ELEMENT CONTENT OF MARINE BLACK SHALES AND RELATED SEDIMENTARY ROCKS, 1930-65
}

\author{
By Elizabeth B. Tourtelot
}

\section{INTRODUCTION}

This bibliography presents minor-element data from analyses of black shales and related organic-rich sedimentary rocks plus selected discussions on the source of the minor elements. Shales generally contain greater quantities of minor elements than do sandstones or limestones (Turekian and Wedepoh1, 1961, table 2). However, many fine-grained sedimentary rocks and unconsolidated sediments that are rich in carbonaceous matter, such as black shales and euxinic muds of modern seas, contain unusually high concentrations of minor elements (Krauskopf, 1955). In the Mansfeld district of Germany, the Kupferschiefer, a bed of black shale about 1 meter thick, has been mined for copper for centuries. Locally, the same bed or its equivalent contains economic concentrations of lead, zinc, silver, and other metals. Copper is also produced from a black shale of Precambrian age in northern Michigan. Black shales have been studied as possible low-grade resources of other metals, including uranium and vanadium, especially in the lower Paleozoic rocks of northern Europe. In some parts of the world, black shales are parent materials of soils associated with selenium poisoning of livestock. Thus, minor-element concentrations in black shales can have many economic implications.

How common are metal-rich black shales? Are they limited to metallogenic provinces, to certain time periods, or to specific environments of deposition? If not otherwise of economic value, do they represent a potential source of metals that may be redistributed and enriched by granitization, metamorphism, or hydrothermal activity? What is the origin of the metals in black shales? Are they concentrated by means of biological activity, by sorption from sea water by decaying organisms, by sulfide precipitation in a reducing environment, or by epigenetic mineralization? Can analogues be identified in modern sediments from inland seas, restricted shallow marine basins, or deep-sea troughs? In the search for answers to these and similar questions, perhaps another Kupferschiefer or other deposit of economic value may be discovered. 
This bibliography is intended as an aid in this search. It may also serve as a guide to suggest what quantities of minor elements in black shales are anomalous. By indicating the types and amounts of published data available, the limits of our knowledge of black shales are roughly outlined and perhaps new directions for investigation are suggested.

Interest in the geochemistry of rocks rich in organic matter arose with the development of the emission spectrographic technique in the 1920's. By use of this technique, a large number of minor elements in very small amounts can be identified in many different materials. During the 1930's, V.M. Goldschmidt and his students in Göttingen reported many examples of unusual concentrations of minor elements in organic-rich rocks and their ashes, including black shales, coals, bitumen, and kolm (a jet-black organic substance that occurs in some lower Paleozoic shales). In an effort to determine the distribution and crustal abundance of various elements, Goldschmidt and his students made many different analyses of a composite sample of 36 European Paleozoic shales. The reported results of these analyses are of interest not only because some black shales are included in the composite, but also because these analyses provided the first indications of the amount of each element that could be reasonably expected in a fine-grained sedimentary rock.

Many later papers, such as that by Vinogradov and Ronov (1956) on the abundance of elements in rocks of the Russian platform (summarized by Green, 1959), serve also to suggest the normal range in abundance of various elements. Many of the articles from the Russian literature compare average abundance data for different lithologies and for rocks of different ages in an attempt to define possible changes in element content with grain size and possible trends through geologic time.

Goldschmidt and Peters (1932c) suggested that boron content in sedimentary rocks appeared to vary with the salinity of the depositional environment. In many subsequent articles, attempts have been made to distinguish different environments of deposition by the amounts or ratios of minor elements. Special emphasis has been placed on methods of distinguishing marineand nonmarine rocks by the use of indicator elements. (See, for example, Degens, Williams, and Keith, 1957.) Many of these articles contain data on the abundance of other elements in addition to boron in a variety of sedimentary rocks, including black shales and related sediments.

Many geochemists accept the theory that unusually high concentrations of minor elements in some black shales are of syngenetic origin - that is, the elements were emplaced at the same time that the mud was deposited without significant later additions. Mechanisms of emplacement, whether by fixation by living organisms, adsorption by decaying organic matter 
from sea water, or reduction and precipitation in an environment of negative Eh and low $\mathrm{pH}$, are still subject to discussion. In these shales, no recognizable evidence exists for appreciable later additions of minor elements. The metals are usually found combined with the organic materials or clay minerals or are carried in pyrite. Black shales of this type include many rich in uranium and vanadium such as the Alum shales of Sweden and the Chattanooga Shale of Tennessee.

In contrast to these, some black shales, such as the Kupferschiefer of Germany, the Mount Isa shale of Australia, and the Nonesuch Shale of Michigan, contain identifiable sulfides of copper, lead, zinc, or other metals. Whether such deposits are syngenetic or epigenetic is subject to controversy. Many references to these shales are included in this bibliography (for example, Wedepohl, 1964b; Love and Zimmerman, 1961) because they have direct bearing on the origin and distribution of minor elements in black shales. However, this bibliography is not intended to be comprehensive on the subject of strata-bound ore deposits. Thus, no references are included on the Northern Rhodesian Copperbelt, for example, because the ores occur in a variety of rock types in addition to black shale.

The study of minor-element distribution in black shale may provide additional evidence on the origin of some of these controversial deposits. Perhaps syngenetic deposits are characterized by a suite of elements significantly different from that of epigenetic deposits. More needs to be known about the effects of diagenesis on element suites also. Metasomatism at the trace-element level has been noted (Shaw, 1954a).

Metal-rich black shale deposits with possible economic potential, equivalent to that of deposits that have been repeatedly described, may be readily overlooked. Several stratigraphic units in the western United States reported by Davidson and Lakin $(1961,1962 \mathrm{~b})$ may be worthy of more attention than they have received. More recently, beds of metalrich black shale on the north slope of the Brooks Range in Alaska have been reported (H. A. Tourtelot, written commun., 1965). Other metalrich black shale deposits have probably been overlooked because those who described the rocks had no reason to suspect they might contain unusual amounts of metals. Gold, for example, might be easily overlooked if its grain size is too small to be visible, because routine spectrographic analyses are not sufficiently sensitive to identify it in small amounts. Nevertheless, gold is reported in several black shale units in quantities that should encourage more thorough study of its distribution (Crouse, 1925; DeGrazia and Haskin, 1964; Leutwein, 1951a, 1951b, 1952; Tischendorf, 1959). 


\section{ANALYSES INCLUDED}

Elementsconsidered "minor elements" include all but silicon, aluminum, iron, calcium, sodium, potassium, oxygen, hydrogen, nitrogen, magnesium, sulfur, phosphorus, and the inert gases. Some complete rock analyses have been quoted, but generally, for the sake of brevity, only minorelement data are included in the abstracts.

In general, the limits of the term "black shale" as discussed by Swanson (1961) have been followed. Black shale, as the term is used here, is a finegrained sedimentary rock containing sufficient organic matter to color the rock dark gray to black; rocks composed largely of carbonate minerals are normally excluded, although some black shales are transitional with carbonate rocks. Terms such as "alum shale," "gyttja shale," "sapropel," "oil shale," "bituminous shale," "carbonaceous shale," and "organic-rich shale" are also used to describe particular black shales.

Although the analyses quoted in this bibliography pertain chiefly to marine black shales and black organic-rich muds being deposited at the present time in reducing environments such as in the Black Sea, fjords, lagoons, and closed ocean deeps, compilations of general abundance data for minor elements in fine-grained sedimentary rocks and modern ocean sediments are also included. Similarly, abundance data for composite samples are quoted, especially where it is believed that the composite included some black shale samples. The most often analyzed composite samples are: (1) 36 European Paleozoic shales, (2) 14 Japanese Paleozoic shales, and (3) 10 Japanese Mesozoic shales. The samples included in the composite of 36 European Paleozoic shales are described by Noll (1934, p. 537-538). Only the localities of the Japanese shale samples which were prepared by Minami (1935a, 1935b) have been published. However, Wedepohl $(1956$, p. 121) believed that some bituminous shale samples are included in the Japanese composites because of their relatively high lead contents.

Most of the papers included describe unmetamorphosed sedimentary rocks, but some describe the minor-element content of black graphitic schists. Papers about shales for which a syngenetic origin for the minorelement content is described or inferred are cited, as are those papers about shales in which epigenetic enrichment is considered minor in comparison to syngenetic concentrations of elements. Discussions of the sources and types of mineralization of black shales are also included.

Articles and books published from 1930 through 1965 which could be obtained by U.S. Geological Survey Library in Denver, Colo., were reviewed, and a few classical older papers as well. Literature abstracted includes that published in the major European languages and Russian. The U.S. Board on Geographic Names style of transliteration has been used for Russian titles. Wherever possible, for the purposes of this bibliography, the author's abstract has been used. The word "condensed" 
after an abstract means that the author's abstract has been condensed. The word "modified" after an abstract means that data or information from the rest of the article has been added to the author's abstract. If the article is not primarily about black shale, data pertinent to black shale have been abstracted from the text, and these abstracts are marked by the initials of the abstractor: EBT, Elizabeth B. Tourtelot, JDV, James D. Vine.

The reader interested specifically in the distribution of uranium in black shales of the United States is referred, for a thorough coverage of this subject, to the annotated bibliography compiled by Fix (1958). A few references in Fix (1958) that include data on other minor elements in addition to uranium have been included here, as well as those papers published after the cutoff date for that compilation (June 30,1956), but most of the uranium references have been excluded to avoid duplication.

Data are presented in percent or in parts per million (ppm) and in some cases have been converted to parts per million from percent or from grams per ton or from ounces per ton for ease of comparison. Conversion factors used are:

\begin{tabular}{lcccr}
\multicolumn{4}{c}{ [Grams per ton = micrograms per $\mathrm{gram}=\mathrm{ppm}$; 1 troy ounce per ton $\mathrm{Au}$ or $\mathrm{Ag}=34 \mathrm{ppm}]$} \\
\hline Fractional notation & Decimal notation & Exponential notation & Percent & Parts per million \\
\hline $1 / 10$ & 0.1 & $1 \times 10^{-1}$ & 10 & 100,000 \\
$1 / 100$ & .01 & $1 \times 10^{-2}$ & 1 & 10,000 \\
$1 / 1,000$ & .001 & $1 \times 10^{-3}$ & .1 & 1,000 \\
$1 / 10,000$ & .0001 & $1 \times 10^{-4}$ & .01 & 100 \\
$1 / 100,000$ & .00001 & $1 \times 10^{-5}$ & .001 & 10 \\
$1 / 1,000,000$ & .000001 & $1 \times 10^{-6}$ & .0001 & 1 \\
\hline
\end{tabular}

If much detailed data are in the article, these are reduced to ranges, or the author's means or averages are quoted. Chemical, quantitative spectrographic, and semiquantitative spectrographic analyses are included. Critical evaluation of the data is left to the reader.

\section{N D E X IN G}

Articles cited are indexed under a geographic or area name if they are concerned with a specific area, and, under element or element group (for example, gold, alkali metals, rare-earth elements) if appropriate. If 10 or more unrelated elements are concerned, as in many of the articles reporting spectrographic analyses, the article is indexed under "Minor elements." In many cases data on the following elements are included: barium, beryllium, boron, chromium, cobalt, copper, gallium, germanium, lanthanum, lead, manganese, molybdenum, nickel, scandium, silver, strontium, tin, titanium, vanadium, yttrium, ytterbium, zinc, and zirconium. Articles containing data on elemental abundance in specific rock types, or discussion on the distribution of the elements, their source, 
geochemical relations, geochemical ratios, or their use as geochemical indicators of the environment of deposition are also indexed under the primary heading "Geochemistry." Specific topics are also indexed, such as sulfide ore, Kupferschiefer, alum shale, and ocean sediment. The heading "Ocean sediment" is broadly used to include sediments of inland seas like the Black Sea as well as deep-sea sediments. The age of the rocks discussed is never used as a primary heading in the index, but is commonly used as a secondary heading. Third order headings include most of the same categories as first order headings, but the same category is not repeated in a single index set. All indexing was designed for existing computer programs.

\section{ACKNOWLEDGMENTS}

This compilation was initiated in connection with an investigation of the distribution of minor elements in black shale by James D. Vine, who provided guidance with respect to the scope of the abstracts included and assistance and encouragement throughout its preparation. Many others provided generous help and access to their files of references and reprints. Among these, I especially thank Harry A.Tourtelot, Vernon E. Swanson, and Michael Fleischer. I also thank Irvil P. Shultz, Eunice G. Speiser, and other members of the staff of the Denver U.S. Geological Survey Library without whose help many publications would have been lost to the writer. I deeply appreciate the help given by Ivan J. Mittin with the Russian translations and by Theodore G. Botinelly, whose knowledge of German, French, and Italian aided in the reading of much of the European literature. James W. Clarke provided computer programing for photocomposing of the abstracts and index.

\section{ABBREVIATIONS OF SERIALS}

Acad. Polonaise Sci. Bull., sér. sci. géol. et géog.-Bulletin de l'Academie Polonaise des Sciences, série des sciences géologiques et géographiques. Warsaw, Poland.

Acad. Rep. Pop. Romîne, Filiala Iaşi, Studii Cercetări Ştiinţ. Chimie-Academia Republicii Populare Romîne, Filiala Iaşi, Studii şi Cercetări Ştiinţifice Chimie. Bucharest, Romania.

Acad. Rep. Pop. Romîne, Secţ. Ştiinţe Geol., Geog., Biol., Analele--Analele Academiei Republicii Populare Romîne, Şectiunea de Ştiinţe Geologice, Geografice şi Biologice. Bucharest, Romania.

Acad. Sci.USSR Doklady-Academy of Sciences of the USSR, Doklady (English translation). Consultants Bureau, Incorporated. New York, N.Y.

Acad. Sci. USSR Doklady, Earth Sci. Sec.-Academy of Sciences of the USSR, Doklady, Earth Sciences Sections (English translation). American Geological Institute. Washington, D.C.

Acta Geol.-Acta Geologica, Magyar Tudományos Akademia. Budapest, Hungary.

Adv. Sci.-Advancement of Science; the report of the British Association for the Advancement of Science. London, England.

Akad. Nauk SSSR Comptes rendus (Doklady)-Akademiya Nauk SSSR Comptes rendus (Doklady). Moscow, USSR. 
Akad. Nauk SSSR Doklady-Doklady Akademii Nauk SSSR. Moscow, USSR.

Akad. Nauk SSSR, Inst. Geol. Nauk, Trudy, Geol. ser.-Trudy Instituta Geologicheskikh Nauk, Akademiya Nauk SSSR, Geologicheskiy Serii. Moscow, USSR.

Akad. Nauk SSSR, Inst. Geol. Nauk, Trudy, Mineralog. i Geokhim. ser.-Trudy Instituta Geologicheskikh Nauk, Akademiya Nauk SSSR, Mineralogicheskiy i Geokhimicheskaya Seriya. Moscow, USSR.

Akad. Nauk SSSR, Inst. geologii rudnykh mestorozhdrniy, petrografii, mineralogii, i geokhimii, Trudy-Trudy Instituta geologii rudnykh mestorozhdeniy, petrografii, mineralogii,i geokhimii. Mosow, USSR.

Akad. Nauk SSSR, Inst. Mineralogii, Geokhimii i Kristallokhimii Redkikh Elementov, Trudy-Institut Mineralogii, Geokhimii i Kristallokhimii Redkikh Elementov, Akademiya Nauk SSSR, Trudy. Moscow, USSR.

Akad. Nauk SSSR, Inst. Nefti, Trudy-Trudy Instituta Nefti, Akademiya Nauk SSSR. Moscow, USSR.

A kad.Nauk SSSR Izv.,Ser.Geol.--Izvestiya Akademii Nauk SSSR, Seriya Geologicheskaya. Moscow, USSR.

Akad. Nauk Uzbek. SSR Doklady-Doklady Akademii Nauk Uzbekskoy SSR. Tashkent. Uzbekistan SSR.

Akad. Nauk Uzbek. SSR, Uzbek. Geol. Zhur.-Uzbekskiy Geologicheskiy Zhurnal, Akademiya Nauk Uzbekskoy SSR. Tashkent, Uzbekistan SSR.

Akad. Nauk Uzbek. SSR, Voprosy geologii Uzbek.-Voprosy geologii Uzbekistana, A kademiya Nauk Uzbekskoy SSR. Tashkent, Uzbekistan SSR.

Akad. Wiss. [Göttingen], math.-phys.-chem. Abt., Nachr.-Nachrichten der Akademie der 'Wissenschaften, in Göttingen, mathematisch-physikalische Abteilung. Göttingen, Germany.

Alsace-Lorraine, Service Carte Géol. Bull.--Bulletin des Services de la Carte Géologigue d'Alsace et de Lorraine. Strasbourg University, France.

Am. Assoc. Petroleum Geologists Bull.-Bulletin of the American Association of Petroleum Geologists. Tulsa, Okla.

Am. Jour. Botany-American Journal of Botany. Botanical Society of America. Baltimore, Md.

Am. Jour. Sci.-American Journal of Science. New Haven, Conn.

Am. Mineralogist-American Mineralogist. Mineralogical Society of America. Washington, D.C.

Angew. Chemie-Angewandte Chemie. Gesellschaft Deutscher Chemiker. Verlag Chemie. Weinheim/Bergatrasse, Germany.

Arkansas Geology Conserv. Comm. Inf. Circ--Arkansas Geology and Conservation Commission Information Circular. Little Rock, Ark.

Archiv Lagerstättenf.-Prussia geologische Landesanstalt, Archiv für Lagerstättenforschung. Berlin, Germany.

Arkiv Kemi, Mineralogi, Geologi-Arkiv för Kemi, Mineralogi och Geologi. Utgivet av Kungliga Svenska Vetenskapsakademien. Stockholm, Sweden.

Australasian Inst. Mining and Metallurgy Proc.-Proceedings of the Australasian Institute of Mining and Metallurgy. Melbourne, Australia.

Azerbaidzhan. Gos. Univ., Uchenye Zapiski, Ser. Geol.-Geograf. Nauk-Uchenye Zapiski, Azerbaidzhanskii Gosudarstvennyi Universitet imeni S. M. Kirova, Seriya Geologo-Geograficheskikh Nauk. Baku, Azerbaidzhan SSR.

Azerbaidzhan. Khim. Zhur.-Azerbaidzhanskii Khimicheskii Zhurnal. Akademiya Nauk Azerbaidzhanskoi SSR. Baku, Azerbaidzhan SSR.

Bergbauwissenschaften-Bergbauwissenschaften. Organ für den Gesamten Bergbau und seine Grenzgebiete. Wilhelmshaven, Germany.

Brigham Young Univ. Geology Studies-Brigham Young University Geology Studies. Provo, Utah. 
Bull. Ver. Schweizer. Petroleum-Geologen u. Ingenieure-Bulletin der Vereinigung der

Schweizerischen Petroleum-Geologen und Ingenieure. Zurich, Switzerland.

Canadian Jour. Research-Canadian Journal of Research. Ottawa, Ontario, Canada.

Chem. Soc. Japan Bull.-Bulletin of the Chemical Society of Japan. Tokyo, Japan.

Chemie der Erde-Chemie der Erde. Zeitschrift für chemische Mineralogie, Petrographie,

Bodenkunde, Geochemie und Meteoritenkunde. Jena, Germany.

Chicago Nat. History Mus., Fieldiana, Geology Mem.-Chicago Natural History Museum, Fieldiana, Geology Memoirs. Chicago, Ill.

Czechoslovakia Státního Geol. Ustavu Věstník-Věstník, Státního Geologického Ustavu Ceskoslovenské Republiky. Nakladatelstvi Ceskoslovenské Akademie ved. Prague, Czechoslovakia.

Dansk Geol. Foren., Medd.-Meddelelser fra Dansk Geologisk Forening, Dansk Geologisk Forening. Copenhagen, Denmark.

Deutschen Akad. Wiss. Berlin Abh., math.-phys. Kl.-Abhandlungen der Deutschen Akademieder Wissenschaften zu Berlin, Klasse für Mathematik und Physik. AkademieVerlag. Berlin, Germany.

Eclogae Geol. Helvetiae-Eclogae Geologicae Helvetiae. Schweizerische Geologische Gesellschaft. Lucerne, Switzerland.

Econ. Geology-Economic Geology and the Bulletin of the Society of Economic Geologists. Urbana, Ill.

Egyptian Acad. Sci. Proc.-Proceedings of the Egyptian Academy of Sciences. Cairo, Egypt.

Erdöl u. Kohle-Erdöl und Kohle. Organ der Deutschen Gesellschaft für Mineralölwissenschaft und Kohlechemie. Hamburg, Germany.

Finlande Comm. Géol. Bull--Bulletin de la Commission Géologique de Finlande (Geologinen Tutkimuslaitos). Helsinki, Finland.

Fortschr. Mineralogie, Stuttgart-Fortschritte der Mineralogie. E. Schweizerbart'sche Verlagsbuchhandlung. Stuttgart, Germany.

Fortschr. Geologie Rheinland u. Westfalen-Fortschritte in der Geologie von Rheinland und Westfalen. Geologische Landesamt Nordrhein-Westfalen. Krefeld, Germany.

Freiberger Forschungshefte--Freiberger Forschungshefte. Akademie-Verlag. Berlin, Germany.

Geochemistry-Geochemistry (English translation). Geochemical Society. Washington, D.C.

Geochemistry Internat.-Geochemistry International (English translation). Geochemical Society. Washington, D.C.

Geochim. et Cosmochim. Acta-Geochimica et Cosmochimica Acta. Pergamon Press. London, England.

Geokhimiya-Geokhimiya. Akademiya Nauk SSSR. Moscow, USSR.

Geol. Fören. Stockholm Förh-Geologiska Föreningens i Stockholm Förhandlingar. Stockholm, Sweden.

Geol. Gesell. Berlin-Berichte der Geologischen Gesellschaft in der Deutschen Demkratischen Republik für das Gesamtgebiet der Geologischen Wissenschaften. Berlin, Germany.

Geologiya i Geokhimiya--Geologiya i Geokhimiya, Veseoyuznyi Neftyanoi NauchnoIssledovatel'skii Geologorazvedochnyi Institut, Nauchno-Tekhnicheskoe Obshchestvo Neftyanoi i Guzovoi Promyshlennosti, Doklady i Stat'i. Gostoptekhizdat. Leningrad, USSR.

Geol. Jahrb.-Geologisches Jahrbuch. Bundesanstalt und Niedersächsisches, Landesamt für Bodenforschung. Hannover, Germany.

Geol. Rundschau-Geologisches Rundschau. Ferdinand Enke Verlag. Stuttgart, Germany. Geol. Soc. America Bull.--Geological Society of America Bulletin. New York, N.Y. 
Geol. Soc. America Spec. Paper-Geological Society of America Special Paper. New York, N.Y.

Geologie-Geologie; Zeitschrift für das Gasamtgebiet der Geologie und Mineralogie Sowie der Angewandten Geophysik. Berlin, Germany.

Gesell. Wiss Göttingen Nachr., math.-phys. K1.-Nachrichten von der Gesellschaft der Wissenschaften zu Göttingen, mathematische-physikalische Klasse. Göttingen, Germany.

Gesell. Wiss. Göttingen Nachr., math.-phys. Kl., Geologie u. Mineralogie-Nachrichten von der Gesellschaft der Wissenschaften zu Göttingen, mathematische-physikalische Klasse, Geologie und Mineralogie. Göttingen, Germany.

Glückauf-Glückauf. Bergmännische Zeitschrift. Verlag Glückauf. Essen, Germany.

Great Britain Geol. Survey Bull.-Bulletin of the Geological Survey of Great Britain. London, England.

Hallesches Jahrb. Mitteldeutsche Erdgeschichte-Hallesches Jahrbuch für Mitteldeutsche Erdgeschichte. VEB Wilhelm Knapp Verkag. Halle, Germany.

Helvetica Chim. Acta-Helvetica Chimica Acta. Endenda Curat Societas Chimica Helvetica. Basel, Switzerland.

Illinois Geol.Survey Circ.-Illinois State Geological Survey Circular. Urbana, Ill.

Ingeniörs Vetenskaps Akad. Handl.-Ingeniörs Vetenskaps Akademiens Handlingar. Stockholm, Sweden.

Inst. Marine Sci. Pub.-Publications of the Institute of Marine Science. University of Texas. Port Arkansas, Tex.

Inst. Petroleum Jour. [London]-The Institute of Petroleum Journal. London, England.

Inst. Petroleum, Oil Shale and Cannel Coal-The Institute of Petroleum, Oil Shale and Cannel Coal. London, England.

Internat. Geol. Cong., 18th, London, 1948, Rept.-International Geological Congress, Report of the 18th Session, Great Britain. London, England.

Internat. Geol. Cong., 21st, Copenhagen, 1960, Doklady Sovetskikh Geologov-International Geological Congress, 21 st Session, Doklady Sovetskikh Geologov. Akademiya Nauk SSSR. Moscow, USSR.

Internat. Geol. Cong., 21st, Copenhagen, 1960, Rept.-International Geological Congress, Report of the 21 st Session Norden. Copenhagen, Denmark.

Internat. Geology Rev.-International Geology Review. American Geological Institute. Washington, D.C.

Internat. Ser. Mon. Earth Sci.-International Series of Monographs on Earth Sciences. Pergamon Press. London, England.

Internat. Soc. Soil Sci., Comm. 2 and 4, Trans.-International Society of Soil Science, Transactions of the II (Soil Chemistry) and IV (Soil Fertility and Plant Nutrition) Commissions. Hamburg, Germany.

Israel Research Council Bull.-Bulletin of the Research Council of Isreal. Israel ha-Mo'asah ha-le'umit le-mehkar ule-fituah. Jerusalem, Israel.

Jour. Chem. Eng. Data-Journal of Chemical and Engineering Data. American Chemical Society. Washington, D.C.

Jour. Geophys. Research-Journal of Geophysical Research. American Geophysical Union. Washington, D.C.

Jour. Marine Research-Journal of Marine Research. Sears Foundation for Marine Research, Bingham Oceanographic Laboratory, Yale University. New Haven, Conn.

Jour. Sed. Petrology-Journal of Sedimentary Petrology. Society of Economic Paleontologists and Mineralogists, a division of The American Association of Petroleum Geologists. Tulsa, Okla.

Kansas Geol. Survey Bull.--State Geological Survey of Kansas Bulletin. Lawrence, Kans. 
Kentucky Geol. Survey, ser. 6-Kentucky Geological Survey, series 6. Lexington, Ky.

Koninkl. Nederlandse Akad. Wetensch. Proc.-Koninklijke Nederlandse Akademie van

Wetenschappen Proceedings. North-Holland Publishing Company. Amsterdam, Netherlands.

Kungl. Lantbrukshögskolans Ann.--Kungliga Lantbrukshögskolans Annaler. Uppsala University. Uppsala, Sweden.

Mikrochemie-Mikrochemie vereingt mit Mikrochimica Acta. Springer-Verlag. Vienna, Austria.

Mining Mag. [London]-The Mining Magazine. London, England.

Natl. Acad. Sci., Natl. Research Council Pub.-National Academy of Sciences, National Research Council Publication. Washington, D.C.

Nature-Nature. A Weekly Journal of Science. Macmillan (Journals) Limited. London, England.

Naturwissenschaften-Die Naturwissenschaften. Gesellschaft Deutsches Naturforscher und Ärzte, und die Max-Planck-Gesellschaft zur Forderung der Wissenschaften. Berlin, Germany.

Neues Jahrb. Geologie u. Paläontologie Abh.-Neues Jahrbuch für Geologie und Paläontologie Abhandlungen. E. Schweizerbart'sche Verlagsbuchhandlung. Stuttgart, Germany.

Neues Jahrb. Mineralogie Abh.-Neues Jahrbuch für Mineralogie Abhandlungen. E. Schweizerbart'sche Verlagsbuchhandlungen. Stuttgart, Germany.

Neues Jahrb. Mineralogie, Geologie u. Paläontologie, Monatsh., Abh. A-Neues Jahrbuch für Mineralogie, Geologie und Paläontologie Monatshefte, Abhandlungen

A. E. Schweizerbart'sche Verlagsbuchhandlung. Stuttgart, Germany.

New York Acad. Sci. Trans.-Transactions of the New York Academy of Sciences. New York, N.Y.

Norges Geol. Undersökelse-Norges Geologiske Undersökelse. Oslo, Norway.

Okeanologiya-Okeanologiya. Akademiya Nauk SSSR. Leningrad, USSR.

Osterreich. Chemiker-Zeitung-Österreichische Chemiker-Zeitung. Springer-Verlag. Vienna, Austria.

Petroleum [London]-Petroleum. London, England.

Philos. Mag.- The Philosophical Magazine. A Journal of Theoretical, Experimental, and Applied Physics. London, England.

Prog. in Oceanography-Progress in Oceanography. Pergamon Press. London, England.

Referativnyy Zhur.-Referativnyy Zhurnal. Geologiya Institut Nauchnoy Informatzii, Akademiya Nauk SSSR. Moscow, USSR.

Repts. Swedish Deep-Sea Expedition 1947-1948, Spec. Inv.-Reports of the Swedish Deep-Sea Expedition 1947-1948, Special Investigations. Göteborgs Kungliga Vetenskaps- och Vitterhets-Samhälle. Swedish Natural Science Research Council. Stockholm, Sweden.

Rocznik Polsk. Towarzystwa Geol.-Rocznik Polskiego Towarzystwa Geologicznego. Annales de la Société Géologique de Pologne. Krakow, Poland.

Royal Irish Acad. Proc.-Proceedings of the Royal Irish Academy. Dublin, Ireland.

Royal Soc. London Proc.-Proceedings of the Royal Society of London. London, England. Sbornik Vysoke Skoly, Chem.-Technol. v Praze, Oddil Fak. Anorg. a Org. Techn.-Sbornik

Vysoke Skoly Chemicko-Technologicke v Praze, Oddil Fakulty Anorganicke a

Organicke Technologie. Statni Pedagogicke Nakladatelstvi. Prague, Czechoslovakia.

Science-Science.American Association for the Advancement of Science. Washington, D.C.

Soc. française minéralogie et crystallographie Bull.-Bulletin de la société française de minéralogie et de crystallographie. Paris, France.

Soc. géol. France Bull.-Bulletin de la Société geólogique de France. Paris, France.

Soil Science-Soil Science. Williams and Wilkins Company. Baltimore, Md. 
South Dakota Acad. Sci. Proc.-Proceedings of the South Dakota Academy of Science. University of South Dakota. Vermillion, S. Dak.

South Dakota Agr. Expt. Sta. Tech. Bull.-South Dakota State College of Agriculture and Mechanical Arts, Agriculture Experiment Station, Bulletin; Technical Bulletin. Brookings, S. Dak.

Sovrem. Methody Mineralog. Issledov. Gornykh Porod, Rud i Mineralov-Sovremennye Methody Mineralogicheskogo Issledovaniya Gornykh Porod, Rud i Mineralov, Vsesoyuznyi Nauchno-Issledovatel'skii Institut Mineral'nogo Syr'ya. Gosgeoltekhizdat. Leningrad, USSR.

Svensk Kem. Tidskr.-Svensk Kemisk Tidskrift. Svenska Kemistsamfundet. Stockholm, Sweden.

Sveriges Geol. Undersökn., ser. C, Årsb.-Sveriges Geologiska Undersökning, series C, Årsbok. Stockholm, Sweden.

Tohoku Univ. Sci. Repts.-Science Reports of the Tohoku University. Faculty of Science. Sendai, Japan.

Tschermaks Mineralog. u. Petrog. Mitt.-Mineralogische und petrographische Mitteilungen, Tschermaks. Springer-Verlag. Vienna, Austria.

United Nations Internat. Conf. Peaceful Uses Atomic Energy, 2d, Geneva, 1958, Proc.Proceedings of the United Nations International Conference on Peaceful Uses of Atơmic Energy, Second, Geneva, 1958. New York, N.Y.

U.S. Bur. Mines Inf. Circ.-United States Bureau of Mines Information Circular. Washington, D.C.

U.S. Bur. Mines Rept. Inv.-United States Bureau of Mines Report of Investigations. Washington, D.C.

U.S. Dept. Agriculture, Agr. Handb.-United States Department of Agriculture, Agricultural Handbook. Washington, D.C.

U.S. Dept. Agriculture Tech. Bull-—United States Department of Agriculture Technical Bulletin. Washington, D.C.

U.S. Geol. Survey Bull.--United States Geological Survey Bulletin. Washington, D.C.

U.S. Geol. Survey Circ.--United States Geological Survey Circular. Washington, D.C.

U.S. Geol. Survey Mineral Inv. Field Studies Map-United States Geological Survey Mineral Investigations Field Studies Map. Washington, D.C.

U.S. Geol. Survey Prof. Paper-United States Geological Survey Professional Paper. Washington, D.C.

Vses. Neft. nauchno-issledov. Geol.-razved. Inst., Trudy-Trudy Vsesoyuznogo Neftyanogo nauchno-issledovatel'skogo Geologorazvedochnyigo Instituta Trudy (Vnigri) (Geokhimicheskii Sbornik). Leningrad, USSR.

Warsaw Inst. Geologiczny Biul.-Biuletyn, Instytut Geologiczny. Państowowy Instytut. Wydawnictwa Geologiczny. Warsaw, Poland.

Washington Acad. Sci. Jour.-Journal of the Washington Academy of Sciences. W ashington, D.C.

Western Miner-Western Miner [formerly Western Miner and Oil Review]. J. E. Mills. Vancouver, British Columbia, Canada.

Wyoming Geol. Survey Bull.-Geological Survey of Wyoming Bulletin. University of Wyoming. Laramie, Wyo.

Yorkshire Geol. Soc. Proc.-Proceedings of the Yorkshire Geological Society. Leeds, England.

Zeitschr. angew. Geologie-Zeitschrift für angewandt Geologie. Staatliche Geologische Kommission. Berlin, Germany.

Zeitschr. angew. Mineralogie-Zeitschrift für angewandte Mineralogie. Verlag von Gebruder Bornträger. Berlin, Germany. 



\title{
ABSTRACTS
}

\author{
Abe, Masahiro. See Kato, Iwao. 00216
}

00001 Adams, J. A. S.; Weaver, C. E. Thorium-to-uranium ratios as indicators of sedimentary processes-example of concept of geochemical facies: Am. Assoc. Petroleum Geologists Bull., v. 42, no. 2, p. 387-430, 1958.

More than $200 \mathrm{Th}$ and $U$ determinations were made by a gamma-ray spectral technique and by an alpha activity-fluorometric uranium technique. Together these two independent methods can be used as a test of secular radioactive equilibrium. $\mathrm{Th}: \mathrm{U}$ ratios in sedimentary rocks range from $<0.02$ to $>21$. Ratios in many oxidized continental deposits are above 7; in most marine depoits they are much below 7 . Th content in shales varies much less than $U$ content. Contents of $U$ and $T h$ found in black marine shales are (age, name of unit, and location, respectively; data in ppm): Jurassic Fernie, Alberta, U 1.4, Th 12, Th:U 8.5; Cretaceous Dakota, Colo., U 3.6, 4.8, Th 19, 21, Th:U 5.2, 4.3; Devonian, west Texas, U 6.9, Th 28, Th:U 4.1; Cretaceous, Calif., U 4.2, Th 9.5, Th:U 2.2; Cretaceous Cantuar, Alberta, U 14, Th 28, Th:U 2.0; Mississippian Barnett, Texas, U 9.9, 8.8, Th 13, 5.2, Th:U 1.3, 0.6; Miocene, Calif., U 22, 14.4, Th 16, 3.6, Th:U 0.75, 0.25; Pennsylvanian Heebner, Kans., U 32, Th 9.8, Th:U 0.3; Devonian Antrim, Mich., U 17.5, Th 2.8, Th:U 0.16; Mississippian Woodford, Texas, U 65, Th 7.4, Th:U 0.11; Mississippian Chattanooga, Tenn., U 80, Th 6, Th:U 0.07.--Authors' abs., modified.

Adams, J. A.S. See Pliler, R. 00266

00002 Adyshev, M. M.; Shabalin, V. V.; Kalmurzaev, K. E. Rasseyannye elementy v kembriyskikh otlozheniyakh khrebta Dzhetym-Too (Tsentral'nyy Tyan'-Shan) [Trace elements in Cambrian rocks of the Dzhetym-Too Range (Central Tien Shan)]: Akad. Nauk SSSR Doklady, v. 151, no. 2, p. 422-425; English translation: Acad. Sci. USSR Doklady, Earth Sci. Sec: Am. Geol. Inst., v. 151, no. 1/6, p. $170-172,1963$.

In Cambrian rocks of the Dzhetym-Too Range 23 elements were detected. These rocks are typical transgressive marine sediments. The middle part of the sequence is composed of dark- to light-gray siliceous rocks and dark-grey to black carbonaceous siliceous rocks which grade upwards into dark-gray calareous siliceous shales interbedded with limestone. The black carbonaceous siliceous shales contain sulfides, mostly pyrite, formed in a reducing environment, and 5-10 percent organic matter. The carbonaceous shales have accumulated $\mathrm{Ag}, \mathrm{P}, \mathrm{V}, \mathrm{Mo}, \mathrm{Cu}$, and, to a lesser degree, $\mathrm{Sr}, \mathrm{Zr}, \mathrm{Ba}, \mathrm{Ga}$, and $\mathrm{Mn}$; they also contain $\mathrm{As}, \mathrm{Sb}, \mathrm{Bi}, \mathrm{Sn}, \mathrm{Zn}$, $\mathrm{Hg}$, and, in some samples, $\mathrm{W}$. Most of the elements came into the Cambrian basin as colloids or very fine suspensions. $\mathrm{Ti}, \mathrm{Zr}$, and, in part, $\mathrm{Cr}, \mathrm{Ba}$, and $\mathrm{Ga}$ were in coarser clastics; $\mathrm{Mn}$ and $\mathrm{Sr}$ were in solution. Data are presented in "arbitrary" units.-EBT

00019 Aleksandrov, A. P.; Reznikov, A. P. Malye elementy v osadkakh Azovskogo morya [Minor elements in sediments of the Sea of Azov (in Russian)]: Okeanologiya, v. 4, no. 4, p. 651-653, 1964.

Dried samples of surface deposits from the Sea of Azov were spectrographically analyzed for 25 elements. Ranges of concentrations in 150 samples are (in ppm): Zr 10-1,000; Sr, Ba, Zn 100-3,000; Cr, V 10-300; Pb, Co, Cu, Ga, Y, Yb, Sc, Be, 
Sn 10-30; Ni 10-65; and Mo 10 . $\mathrm{Cr}, \mathrm{V}, \mathrm{Ga}$, and $\mathrm{Cu}$ regularly increase with decreasing grain size, $\mathrm{Zr}$ increases with increasing amounts of heavy minerals, and $\mathrm{Sr}$ increases with increasing carbonate content. Contents of minor elements and their distribution in modern sediments is closely related to the original composition of the material brought into the sedimentary basin. Contents in argillaceous mud

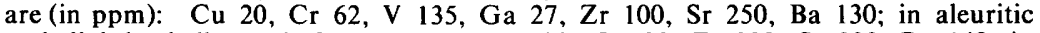
and slightly shelly mud, $\mathrm{Cu} \mathrm{17,} \mathrm{Cr} 70, \mathrm{~V} \mathrm{122,} \mathrm{Ga} \mathrm{20,} \mathrm{Zr} \mathrm{330,} \mathrm{Sr} \mathrm{200,} \mathrm{Ba} \mathrm{140}$; in shelly mud, Cu 20, Cr 30, V 20, Ga 20, Zr 30, Sr 650, Ba 100.-EBT

00020 Allsman, P. T.; Majors, F. H.; Mahoney, S. R.; Young, W. A. Investigation of Sublette Ridge vanadium deposit, Lincoln County, Wyoming: U.S. Bur. Mines Rept. Inv. 4476, 8 p., 1949a.

The vanadiferous deposits of Sublette Ridge and Salt River Range are 2 miles east of Raymond, Idaho, in western Lincoln County, Wyo. They occur in a black carbonaceous shale ranging from 2.5 to $4.3 \mathrm{ft}$ in thickness which is approximately $50 \mathrm{ft}$ below the base of the Rex Chert Member of the Phosphoria Formation of Permian age. Shale beds containing as much as 1.2 percent $\mathrm{V}_{2} \mathrm{O}_{5}$ have been reported. An assay of a typical section of the vanadiferous bed shows (in percent): insoluble 57.8, $\mathrm{SiO}_{2}$ 43.6, $\mathrm{Fe} 3.10, \mathrm{CaO} 9.30, \mathrm{~S} \mathrm{3.85,} \mathrm{CO}_{2} 6.80, \mathrm{Al}_{2} \mathrm{O}_{3}$ 12.55, C 9.90, $\mathrm{P} \mathrm{0.83,}$

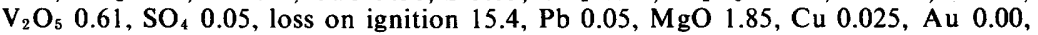

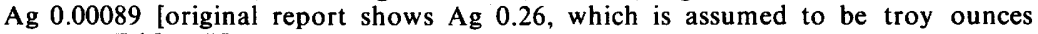
per ton. Ed.].-EBT

00021 Allsman, P. T.; Majors, F. H.; Mahoney, S. R.; Young, W. A. Investigation of Salt River Range vanadium deposits, Lincoln County, Wyoming: U.S. Bur. Mines Rept. Inv. 4503, 18 p., 1949 b.

The Salt River Range vanadium deposits occur 3-6 miles east and southeast of Afton, Wyo. The vanadium occurs in six or more thin beds of carbonaceous black shale in the lower part of the Phosphoria Formation of Permian age. Exploration work by the U.S. Bureau of Mines consisted of surface trenching and underground work over 18 miles of outcrop of vanadiferous shale with an average assay value of 0.866 percent $\mathrm{V}_{2} \mathrm{O}_{5}$ and small quantities of phosphates, fluorides, and Mo. Detailed assays and a geologic map of the area are included in the paper.-EBT

00022 Amirkhanov, Sh. Kh.; Egamberdyev, M. V. Raspredeleniye nekotorykh khimicheskikh elementov $v$ melovykh otlozheniyakh yugozapadnykh otrogov Gissara i ikh korrelyatsionnye znacheniya [Distribution of some chemical elements in Cretaceous deposits of the southwestern spur of Gissar and their correlation significance (in Russian, summ. in Uzbekian)]: Akad. Nauk Uzbek., Voprosy geologii Uzbek., v. 3, p. 83-96, 1962.

Amounts of $\mathrm{Na}, \mathrm{Mg}, \mathrm{Ca}, \mathrm{Sr}, \mathrm{Ba}, \mathrm{V}, \mathrm{Ni}, \mathrm{Cr}, \mathrm{Cu}$ and $\mathrm{Mn}$ were determined in sandstones, siltstones, clays, and limestones (650 samples) of Cretaceous age by a quantitative spectrographic method. Maximum concentrations of $\mathrm{V}(100-2,000$ ppm), $\mathrm{Ni}(30-100 \mathrm{ppm}), \mathrm{Cu}(20-70 \mathrm{ppm})$, and $\mathrm{Cr}(40-80 \mathrm{ppm})$ occurred in clays. Sr content in Albian clays [Lower Cretaceous] was 2,600 ppm. Referativnyy Zhur., 1963, abs. 7V19, condensed.

00023 Amirkhanov, Sh. Kh.; Ismatullaev, Kh. K. O svyazi vanadiya, nikelya i khroma s organicheskim uglerodom $v$ nizhemelovykh otlozheniyakh Zapadnogo Uzbekistana [On the relation of vanadium, nickel and chromium with organic carbon in Lower Cretaceous sediments of western Uzbekistan (in Russian; Uzbekian abs.)]: Akad. Nauk Uzbek. SSR Doklady, v. 19, no. 5, p. 36-38, 1962.

Contents of $\mathrm{V}, \mathrm{Ni}$, and $\mathrm{Cr}$ in the oil matrix formations of western Uzbekistan increased with increased amounts of organic C. Sandstone, siltstone, and clays of Early Cretaceous age were studied from well-core samples from locations on the Kagan and Mubareks uplifts. Contents of $\mathrm{V}, \mathrm{Ni}$, and $\mathrm{Cr}$ in the studied rocks ranged from 0 to $300 \mathrm{ppm}$ and the organic $\mathrm{C}$, from 0.1 to 1.62 percent. In rocks from the lower Albian deposits, amounts of organic $C$ ranged from 0.1 to 1.17 percent, and the contents of the elements (range in ppm) were: in sandstone, $\mathrm{V} 30-140$, $\mathrm{Ni} 50-110, \mathrm{Cr} 40-120$; in siltstone, $\mathrm{V} \mathrm{90-210,} \mathrm{Ni} 70-120, \mathrm{Cr} \mathrm{80-110}$; in clays, V 60-260, Ni 50-150, Cr 30-170. Referativnyy Zhur., 1963, abs. 3V48, condensed. 
00003 Ancizar-Sordo, Jorge. Occurrence of selenium in soils and plants of Columbia, South America: Soil Sci., v. 63, p. 437-438, 1947.

Selenium poisoning occured in cattle, poultry, and humans in the Leiva District, State of Boyaca, Columbia. Soils sampled contained 3.5-7.0 ppm Se, and exposed gray shale, $14 \mathrm{ppm} \mathrm{Se.-EBT}$

Antal, P.S. See Koczy, F. F. 00211

Arnold, J. R. See Merrill, J. R. 00148

00004 Arrhenius, G. O. S. Sedimentation on the ocean floor, in Abelson, P. H., ed., Researches in geochemistry: New York, John Wiley and Sons, Inc., p. 1-24, 1959.

The source of sedimentary minerals can often be determined from their isotopic or elemental composition, crystal structure, or other characteristic properties. Due to its peculiar structure, biogenic apatite dissolving on the deep sea floor offers a suitable surface for adsorption and fixation as phosphates of rare-earth elements and of Th isotopes. Apatite-bearing skeletal debris also contains an organic component consisting mainly of collagen. Heavy-metal ions, mainly $\mathrm{Zn}, \mathrm{Cu}, \mathrm{Pb}$, $\mathrm{Sn}$ and $\mathrm{Ag}$, are transferred from sea water to these organic phases. The $\mathrm{Zn}$ concentration may be 5 percent or more of the organic phase; $\mathrm{Zn}$ appears to occur as salts of higher fatty acids. Marine hydrogenous barite is not common in most parts of the ocean, but below areas of high organic productivity it is present in amounts of several percent, more than 20 times the amounts in adjacent areas.EBT

Arrhenius, G. O.S. See Goldberg, E. D. 00114

00006 Assarsson, G.; Grundulis, V. Chemical investigations of Upper Cambrian shales at Hynneberg, Närke [in English]: Fören. Stockholm Förh., v. 83, p. 269-277; correction p. $433,1961$.

A section through the Upper Cambrian alum shales at Hynneberg, Närke, central Sweden, has been investigated chemically and mineralogically. $X$-ray study shows that quartz, muscovite, and pyrite are the principal minerals; kaolinite, calcite apatite, rutile, and perhaps chlorite are less common. Chemical analyses of 9 shale samples show that the untreated shale contains 15.2 to 17.9 percent organic $\mathrm{C}$; the shale ash $\left(500^{\circ} \mathrm{C}\right)$ contains 0.11 to 0.20 percent $\mathrm{V}_{2} \mathrm{O}_{5}$. The composition of the organic fraction was almost constant, approximately $\mathrm{C}_{10} \mathrm{H}_{11} \mathrm{O}$, plus a little $\mathrm{S}$ and N.-EBT

00005 Assarsson, G. O. Vanadinhalten i svenska oljeskiffrar och vanadinets förekomstsätt [Vanadium content of Swedish oil shale and the nature of the occurrence of vanadium (in Swedish)]: Geol. Fören. Stockholm Förh., v. 63, no. 2, p. 182,1941 .

Alum shale from Närke, Kinnekulle, Ö̈tergötland, of Cambrian and Ordovician age, contains $0.02-0.2$ percent $\mathrm{V}, 0.008-0.03$ percent $\mathrm{Mo}$, and from a trace to some hundredths percent W. V, Mo, and W are combined with sulfides in the shales.EBT

Aswathanarayana, U. See Murty, P. S. N. 00271.

Baas Becking, L. G. M. See Stanton, R. L. 00296

Badak, J. See Kita-Badak, M. 00214

00007 Baedecker, P. A.; Ehmann, W. D. The distribution of some noble metals in meteorites and natural materials: Geochim. et Cosmochim. Acta, v. 29, p. 329$342,1965$.

Abundances of Au and Ir were determined in a wide range of meteoritic and terrestrial materials. Two cores of deep-sea sediments, the Argentine Basin core $\mathrm{V}-18-35$ and the Mid-Pacific Ocean core MP-38, contained the following amounts 
of $\mathrm{Au}$ and Ir (in ppm): Argentine Basin core, $100 \mathrm{~cm}$ depth, Au 0.0026, Ir $140 \times 10^{-5}$; $355 \mathrm{~cm}, \mathrm{Au}--$, Ir $1.2 \times 10^{-5} ; 675 \mathrm{~cm}$, Au 0.0021, Ir $3.3 \times 10^{-5} ; 1,045 \mathrm{~cm}$, Au 0.0030, Ir $14 \times 10^{-5}$; Mid Pacific Ocean core, $12-16 \mathrm{~cm}$, Au --, Ir $30 \times 10^{-5} ; 56-60 \mathrm{~cm}$, Au 0.0090 , Ir $73 \times 10^{-5} ; 214-218,369-373 \mathrm{~cm}, \mathrm{Au}---$, Ir nd. - EBT

00008 Bain, G. W. Patterns to ores in layered rocks: Econ. Geology, v. 55, no. 4, p. $695-731,1960$.

Distribution patterns of syngenetic ore bodies in layered rocks correspond in area, symmetry, and metal variation with rock facies structures. Many deposits have metallization, initially syngenetic, redistributed slightly by ground water of varied origin and thus acquire a tectonic asymmetry while retaining their syngenetic facies limitation. Selected examples of intensively studied deposits, such as the alum shales of Sweden, the German Kupferschiefer, the Congo-Rhodesian copper belt, the Witwatersrand, the Orange Free State gold field, the Blind River uranium area, and the Colorado Plateau uranium deposits, are cited and examined critically, and criteria are presented to indicate the syngenesis or epigenesis of metallization as distinct from mineralization. The metal distribution in the Peltura zone of the Scandinavian Cambrian alum shales is (ppm): V 300-1,500, U 80-250, Mo 120 250, Ni 50-250, Cu 100, Co 10-40, Cr 10, Zn 20, Pb 40, W tr.-Author's abs., modified.

00024 Balashov, Yu. A.; Ronov, A. B.; Migdisov, A. A.; Turanskaya, N. V. Vliyaniye klimaticheskikh $\mathrm{i}$ fatsial'nykh usloviy na razdeleniye redkozemel'nykh elementov $v$ osadochnom protsesse [Influence of climatic and facies conditions on the separation of rare-earth elements in the sedimentation process (in Russian; English abs.)]: Geokhimiya, no. 10, p. 995-1014, 1964.

Middle Paleozoic sediments formed in humid climates have different rare-earth element contents in shales, sands, and carbonates; sediments formed in arid climates have uniform contents. The continental facies near the source area and the marine facies have higher total rare earth contents than the intermediate coal-bearing facies. A systematic change in rare-earth composition occurs from the source area to the marine facies; a similar tendency is outlined in modern sediments. The rare-earth content in Lower Devonian lagoonal clays is (in ppm): La 41, Ce 81, Pr 11, Nd 38, $\mathrm{Sm} \mathrm{8,} \mathrm{Gd} \mathrm{6.6,} \mathrm{Tb---,} \mathrm{Dy} \mathrm{6.4,} \mathrm{Ho}---$, Er 4.4, $\mathrm{Yb} 4.3, \mathrm{Y} \mathrm{45}$, total $\mathrm{R}_{2} \mathrm{O}_{3} 300$; in Lower Carboniferous carbonaceous clay from a humid climate: La 58, Ce 113, Pr 14, Nd 50, Sm 10, Gd 7.6, Tb 2, Dy 5.6, Ho 1.5, Er 35, Yb 3.1, Y 40, total $\mathrm{R}_{2} \mathrm{O}_{3} 350$; in Lower Carboniferous lagoonal clays: La 58, Ce 118, $\mathrm{Pr} 15, \mathrm{Nd} 60$, Sm 14, Gd 12, Tb---, Dy 9, Ho ---, Er 6, Yb 6, Y 65, total $\mathrm{R}_{2} \mathrm{O}_{3} 420$. Samples were taken from the Russian platform.-EBT

Ball, J. S. See Thorne, H. M. 00287

00009 Baranov,V. I.; Ronov, A.B.; Kunashova, K. G. K geokhimii rasseyannogo toriya i urana $\mathrm{v}$ glinakh i karbonatnykh porodakh russkoy platformy [in Russian; English abs.]: Geokhimiya, no. 3, p. 3-8, 1956; English translation, Geochemistry of dispersed thorium and uranium in clays and carbonate rocks of the Russian platform: Geochemistry 1956, no. 3, p. 227-235, 1960.

Determinations of $T h$ and $U$ were made in the standard representative composite samples of carbonate rock and clays ranging in age from late Proterozoic (Sinian) to Quaternary, including 178 composites of clay representative of 4,795 samples. The average Th content in clays of the Russian platform is $11 \mathrm{ppm}$, and the average $U$ content is $4.1 \mathrm{ppm}$. In the earth's crust, Th and $U$ average 8 and $3 \mathrm{ppm}$ respectively. Under especially favorable conditions, $U$ is accumulated in marine silts rich in organic matter and bitumens. In the course of time these sediments are converted into black shale. It appears that $U$ is extracted from the sea water and is adsorbed by the organic substance.-EBT

00025 Baranov, V. I.; Kuz'mina, L. A. Soderzhaniye radioaktivnykh elementov v donnykh otlozheniyakh Tikhogo okena $v$ rayone Yaponskikh ostrovov [Content of radioactive elements in bottom sediments of the Pacific Ocean in the area of the Japanese Islands]: Geokhimiya, no. 1, p. 23-32, 1957; English translation: Geochemistry 1957, no. 1, p. 25-36, 1960. 
The content of radioactive elements has been determined in 5 cores and 7 samples obtained by bottom dredging. In the upper layers of the samples the content of $T h$ is $6 \mathrm{ppm}$, of $U 2-3 \mathrm{ppm}$, and of ionium about $30 \mathrm{ppm}$ (in $U$ units). Ionium decreases regularly with depth. The sedimentation rate as calculated from ionium ranges from $1 \mathrm{~cm}$ in 350 years to $1 \mathrm{~cm}$ in 1,000 years. Comparison of ionium content with contents of $\mathrm{Si}, \mathrm{Fe}$, and $\mathrm{Mn}$ shows that ionium precipitation on the sea floor is a more complex process than simple adsorption by iron or manganese oxide. Clastic layers contain less ionium, clayey layers more; this indicates absorption of ionium by clayey muds. In the core sample taken nearest to shore $\left(37^{\circ} 12^{\prime} \mathrm{N}, 146^{\circ} 52^{\prime} \mathrm{E}\right)$, contents at the top were Th $2.2 \mathrm{ppm}, \mathrm{U} 1.2$, and ionium, as $\mathrm{U}, 10 \mathrm{ppm}$; at $260 \mathrm{~cm}$, Th 2.4, U 2.0, and ionium, as U, $4.4 \mathrm{ppm}$. The core taken at $26^{\circ} 16^{\prime} \mathrm{N}, 145^{\circ} 47^{\prime} \mathrm{E}$ is characterized by soft clayey blackish-brown muds. In it, Th content was 5.3-5.8 ppm; U, 1.0-4.0; and ionium, as U, 4-20 ppm.-Authors' abs., modified.

00010 Barghoorn, E. S.; Meinschein, W. G.; Schopf, J. W. Paleobiology of a Precambrian shale: Science, v. 148, no. 3669, p. 461-472, 1965.

Crude oil, pristane, phytane, sterane-type and optically negative alkanes, porphyrins, microfossils, and the stable isotopes of $C$ and $S$ found in the Nonesuch Shale of Precambrian age from northern Michigan were investigated. The Nonesuch Shale was deposited in a near-shore deltaic environment approximately 1 billion years ago. The thermal stability of the formation supports the concept of low-temperature emplacement of the economically important $\mathrm{Cu}$ in the lowest member, the parting shale, prior to lithification. The direct association of the $\mathrm{Cu}$ minerals with finely disseminated carbonaceous matter, anthraxolithic organic material and partially or wholly devolatized asphaltic organic residues suggests that the presence of organic materials facilitated the precipitation of $\mathrm{Cu}$. Vanadyl porphyrins constitute the major part of $45 \mathrm{ppm}$ (on original rock) of porphyrin aggregate isolated from the benzene-ether extract of the parting shale.-EBT

00026 Barnes, $\mathbf{H}$. L. The effect of metamorphism on metal distribution near base metal deposits: Econ. Geology, v. 54, no. 5, p. 919-943, 1959; abs., Geol. Soc. America Bull., v. 68 , no. 12 , pt. 2 , p. $1699,1957$.

Shales near three base metal deposits were analyzed to determine possible changes in $\mathrm{Zn}, \mathrm{Cu}$, and $\mathrm{Fe}$ distribution. About 140 samples were analyzed colorimetrically from deposits of a contact metasomatic type (Hanover, N. Mex.), a vein type (San Francisco del Oro, Chihuahua, Mexico), and a Mississippi Valley replacement type (Shullsburg, Wis.). Lateral secretion from Paleozoic or later sediments is not a significant process in the formation of ore deposits. The Percha Shale of Late Devonian age, Hanover, contains $70 \mathrm{ppm} \mathrm{Zn}, 48 \mathrm{ppm} \mathrm{Cu}$, and 4 percent $\mathrm{Fe}$; the metal content is the same in the recrystallized and silicified contact zone (excluding skarn). The Maquoketa Shale of Late Ordovician age, Shullsburg, contains $35 \mathrm{ppm}$ $\mathrm{Zn}, 65 \mathrm{ppm} \mathrm{Cu}$, and 3 percent $\mathrm{Fe}$; the oil rock of Middle Ordovician age contains $20 \mathrm{ppm} \mathrm{Zn}, 60 \mathrm{ppm} \mathrm{Cu}$, and 7 percent $\mathrm{Fe}$. Unaltered calcareous black shale from the San Francisco del Oro contains $123 \mathrm{ppm} \mathrm{Zn,} 75 \mathrm{ppm} \mathrm{Cu}$, and 5 percent $\mathrm{Fe}$.EBT

00011 Barnett, P. R. Spectrographic analysis for selected minor elements in Pierre Shale: U.S. Geol. Survey Prof. Paper 391-B, 10 p., 1961.

The accuracy and precision of spectrographic determinations for minor elements is discussed. Spectrographic determinations for 10 elements were made on 80 samples of Pierre Shale of Late Cretaceous age. The range of contents found was (in ppm): B $20-240, \mathrm{Co} 10-34, \mathrm{Cr} \mathrm{3-160,} \mathrm{Ga} \mathrm{6-24,} \mathrm{Ni} \mathrm{36-170,} \mathrm{Sc} \mathrm{5-28,} \mathrm{Sr} \mathrm{73-}$ 2,300 , Ti $1,200-4,600$, and $\mathrm{Zr} 90-230$. The precision of the measurements is discussed in terms of coefficient of variation for single determinations, determinations from different laboratories, and chemical determinations against spectrographic measurements.-EBT

00012 Bates, T. F.; Strahl, E. O. Mineralogy, petrography, and radioactivity of representative samples of Chattanooga Shale: Geol. Soc. America Bull., v. 68, no. 10, p. 1305-1314, 1957. 
Quantitative studies by a combination of chemical and mineralogical methods have shown the composition of a batch sample of the Chattanooga Shale of Devonian and Mississippian age to be approximately (in percent): quartz 22, feldspar 9, illite and kaolinite 31 , organic matter 22 , pyrite and marcasite 11 , chlorite 2 , iron oxides 2 , and tourmaline, zircon, and apatite 1 . No $U$ mineral is present. Mean $U$ content is $45 \mathrm{ppm}$. Data indicate that the $U$ was precipitated from sea water under reducing conditions and has not been redistributed following compaction of the sediment.Authors' abs., condensed.

00027 Bates, T. F.; Strahl, E. O. Mineralogy and chemistry of uranium-bearing black shales: United Nations Internat. Conf. Peaceful Uses Atomic Energy, 2d Geneva, 1958, Proc., v. 2, p. 407-411, 1958; also in University Park, Pa., Pennsylvania State Univ. Dept. Mineralogy and Petrology, 7 p. (Tech. Rept. NYO-7909, prepared for U.S. Atomic Energy Comm.).

Silicate, normative-mineral, and uranium analyses by mineralogical, chemical, and radiometric methods of 1,185 samples from 11 black shales are reported. The samples from France contain abundant meta-autunite, but most of the $U$ in these samples and all of the $U$ in the other shales is loosely held in the fine-grained organic-inorganic matrix of the rock. The average $U$ contents found are (standard deviation in parentheses; in ppm): Cambrian alum shale, Sweden, 168 (254); Ordovician Reedsville Shale, Pennsylvania, 4 (2); Devonian Chattanooga Shale, Tennessee, 62 (24); Devonian Ohio Shale, Ohio, 10 (8); Devonian Woodford Shale, New Mexico, 9 (10); Devonian Hamilton Shale, Pennsylvania, 6 (2); Devonian Chemung Shale, Pennsylvania, 3 (2); Carboniferous St. Hippolyte shale, France, 1,244 (6,054); Pennsylvanian Allegheny shale, Pennsylvania, 4 (2); Pennsylvanian Kansas shale, Kansas, 16 (10); and Permian Kupferschiefer, Germany, 39 (38).EBT

Baturin, G. N. See Kochenov, A. V. 00405

00013 Beath, O. A.; Hagner, A. F.; Gilbert, C. S. Some rocks and soils of high selenium content: Wyoming Geol. Survey Bull. 36, 23 p., 1946.

Critical seleniferous areas in the western United States are correlative with watersoluble Se. Selenate $\mathrm{Se}$ is the dominant form in the rocks and soils considered here. Materials studied include tuffs, sandstone, vanadiferous siltstone, phosphate rock, shales, and vanadium-uranium ores. A black, vanadiferous siltstone in the phosphatic shale member of the Permian Phosphoria Formation in Wyoming is seleniferous. The Se concentration $(287-680 \mathrm{ppm})$ is highest where the $\mathrm{V}$ content $(0.12-2.12$ percent) reaches its maximum. A sample of carbonaceous shale [probably the Manning Canyon Shale] of Late Mississippian and Early Pennsylvanian age from Provo Canyon, Utah, contains $96.3 \mathrm{ppm}$ Se. Some samples of a carbonaceous shale in the Upper Cretaceous Medicine Bow Formation in Albany County, Wyo., assayed more than $150 \mathrm{ppm} \mathrm{Se}$.-EBT

00028 Behne, Walter. Untersuchungen zur Geochemie des Chlor und Brom [Investigation of the geochemistry of chlorine and bromine (in German; English abs.): Geochim. et Cosmochim. Acta, v. 3, p. 186-214, 1953.

A method of chemical analysis of $\mathrm{Cl}$ and $\mathrm{Br}$ in rocks is described. As little as $20 \mathrm{ppm} \mathrm{Cl}$ and $1 \mathrm{ppm} \mathrm{Br}$ can be detected. Sedimentary rocks contain about as much $\mathrm{Cl}$ and more $\mathrm{Br}$ than eruptive rocks. Some $\mathrm{Br}$ is probably accumulated and fixed by terrestrial organisms as it is by marine organisms. In shales the following contents were found (in $\mathrm{ppm}$ ): Lias shale, $\mathrm{Cl} 100,210, \mathrm{Br} \leq 1,5.2$; Keuper shale, $\mathrm{Cl} 370, \mathrm{Br} \leq 1$; Septarien shale, $\mathrm{Cl} 15,20,450, \mathrm{Br} 14.6, \leq 1,58$; Kupferschiefer, $\mathrm{Cl} 270$, nd, $\mathrm{Br} 7,8.7$; Kulm shale, $\mathrm{Cl} 60, \mathrm{Br} 3$; Wissenbacher shale $\mathrm{Cl} 50, \mathrm{Br} 4.2$; black, coaly shale (bituminous) Upper $\mathrm{Daz}, \mathrm{Cl}$ nd, $\mathrm{Br} 29.1$; coaly oil shale (contains about 8 percent bitumen), $\mathrm{Cl}$ nd, $\mathrm{Br} 9.6$; black oil shale (porphyrin shale) Lower Triassic, $\mathrm{Cl}$ nd, $\mathrm{Br} 2.6$.- EBT

00029 Bell, C. K. Some aspects of the geochemistry of gallium [abs.]: Geol. Soc. America Bull., v. 66, no. 12, pt. 2, p. 1529-1530, 1955. 
Quantitative spectrochemical investigations, involving a grating spectrograph, indium as internal standard, and $\mathrm{Ga} 4172:$ In 4101 as analyses pair, contribute new abundance data and indicate gallium's ubiquity, narrow scatter, and close association with $\mathrm{Al}$ in silicate minerals and rocks. Analytical detection limit is $1 \mathrm{ppm}$. Reproducibility expressed as standard deviation is 11 percent. Ga content in shales averages $19 \mathrm{ppm}$, in the lithosphere, $15 \mathrm{ppm}$.--EBT

Berman, H. See Goldschmidt, V. M. 00117

00014 Bidzhiyev, R. A. O raspredelenii "malykh" khimicheskikh elementov v yurskikh i nizhnemelovykh otlozheniyakh Priverkhoyanskogo progiba [Distribution of "minor" chemical elements in the Jurassic and Lower Cretaceous deposits of the Verkhoyansk trough]: Akad. Nauk SSSR Doklady, v. 157, no. 1, p. 112-115, 1964; English translation: Acad. Sci. USSR Doklady, Earth Sci. Sec.: Am. Geol. Inst., v. 157 , no. $1 / 6$, p. $128-131$.

The Jurassic deposits of the Verkhoyansk trough of northern Siberia are mostly shallow-water marine, except for the continental carbonaceous Dzhaskoy Formation. Thick Lower Cretaceous deposits are continental, alluvial-deltaic. All these rocks are saturated with finely dispersed plant detritus. Jurassic argillaceous rocks also contain much nodular, dispersed, or pseudomorphic pyrite. Semiquantitative spectrographic analyses were made of 346 samples; average magnitudes for each rock type were used to prepare distribution curves of $M n, V$, $\mathrm{Cr}, \mathrm{Ni}, \mathrm{Cu}, \mathrm{Co}, \mathrm{Ti}, \mathrm{Ba}, \mathrm{Sr}$, and $\mathrm{Ga}$, elements present in every rock type. The distribution curves suggest that most of the elements were carried into the basin in suspension, and distribution and mineralogical studies show slight chemical weathering of the source rocks, a dry climate, and rugged relief in Jurassic time.EBT

00030 Bitterli, P. Bituminous Posidonienschiefer (Lias Epsilon) of Mont Terri, Jura Mountains [in English]: Bull. Ver. Schweizer. Petroleum-Geologen u. Ingenieure, v. 26 , no. 71 , p. $41-48,1960$.

At Mont Terri, in northwestern Switzerland, the Posidonienschiefer is developed as a bituminous shale $17 \mathrm{~m}$ thick. The rocks range from almost carbonate free to very calcareous shale or marl. The presence of substantial amounts of porphyrins with wavelength [ultraviolet absorption peak] $\pm 570 \mathrm{~m} \mu$ (V complexes) has been observed in all 8 samples, but the $550 \mathrm{~m} \mu$ maxima ( $\mathrm{Ni}$ complexes) are less pronounced and probably absent in 3 samples. The samples contained organic C 2.2-12.2 percent, Si (estimated) 8-10 percent, Al (estimated) 5-10 percent, Fe 1.2-4.9 percent, $\mathrm{Mg} 0.4-0.9$ percent, Ca 9-29 percent, $\mathrm{Mn} 0.3-0.5$ percent, $\mathrm{V} 85$ $230 \mathrm{ppm}$, Ni 70-290 ppm, Mo $<20-100 \mathrm{ppm}$, and $\mathrm{Cu}<20-93 \mathrm{ppm}$.-EBT

00015 Bloxam, T. W. Uranium, thorium, potassium and carbon in some black shales from the South Wales coalfield: Geochim. et Cosmochim. Acta, v. 28, p. 1177 $1185,1964$.

Carboniferous black shales from the Lower and Middle Coal Measures of the South Wales coalfield have been analyzed for $U$, Th, K, and $C$. In the 32 samples investigated, the average values for $U$ and $T h$ are 4.0 and $12.3 \mathrm{ppm}$, respectively, and the $\mathrm{Th} / \mathrm{U}$ ratio 3.2 . $\mathrm{K}$ averages 3.2 percent and organic $\mathrm{C} ! .2$ percent. The amount of $U$ in the samples increases with organic $C$ content, but in general shows an inverse relationship toward Th and K.-Author's abs.

00016 Blumer, Max. Chemische Untersuchungen an bituminösen Gesteinen [Chemical studies of bituminous rocks (in German; English abs.)]: Bull. Ver. Schweizer. Petroleum-Geologen u. Ingenieure, v. 19, no. 56, p. 17-26, 1952.

Problems of the origin of some trace elements in sediments containing much organic material (bituminous shales, asphalt, and oil) and the behavior of organic compounds during sedimentation and diagenesis are reviewed and discussed. Coal has high concentrations of $\mathrm{B}, \mathrm{Ge}, \mathrm{As}$, and $\mathrm{Bi}$; bitumen is enriched in $\mathrm{V}, \mathrm{Ni}, \mathrm{Mo}$, $\mathrm{Cu}$, and $\mathrm{U}$. Trace elements can be collected by the living substance or by the organic compounds released after death. B, Ge, As, and Bi are taken up from ground water by plants and concentrated in the process; during the formation of coal from 
the plant remains they are further concentrated. Decay products of organisms react with ions in sea water to form almost insoluble compounds with effective concentrations of trace elements.-EBT

00017 Blumer, Max; Erlenmeyer, H. Analyses schweizerischer Sediment-Gesteine. Geochemische Untersuchungen 2 [Analyses of Swiss sedimentary rocks. Geochemical study 2 (in German)]: Helvetica Chim. Acta. v. 33, Fasciculus 1, no. 11 , p. $45-56,1950$.

Chemical analytical methods for determining amounts of $\mathrm{Si}, \mathrm{Fe}$, and $\mathrm{Ca}$, and the trace elements $\mathrm{Mn}, \mathrm{Ni}, \mathrm{Mo}, \mathrm{P}, \mathrm{V}$, and $\mathrm{Ti}$ in sedimentary rocks are described. Analyses of some Swiss sedimentary rocks are shown including 18 samples from a profile of bituminous strata [of Anisian (Triassic) age] from Mount St. Giorgio. The range of values is (in percent): $\mathrm{SiO}_{2} 13.6-41.8 ; \mathrm{Fe}, 1.95-10.4 ; \mathrm{Ca}, 0.1-11.4$; P, 0.057-0.53; Ti, 0.06-0.44; V, 0.20-0.35; Mn, 0.0065-0.024; Ni, 0.0014-0.035; Mo, $0.011-0.045$; and loss on ignition, 21.6-53.9.-JDV

00018 Bogvad, Richard; Nielsen, A. H. Vanadinindholdet i en Raekke danske Bjergarter [The quantitative occurrences of vanadium in rocks of Denmark (in Danish: English summ.)]: Dansk Geol. Foren., Medd., v. 10, no. 5, p. 532-540, 1945.

$V$ content has been quantitatively determined in Danish rocks ranging in age from Cambrian to Quaternary. Five groupings occurred: (1) limestone and glauconitic rocks nearly free of $\mathrm{V}$; (2) lignites, $<10 \mathrm{ppm} \mathrm{V}_{;}$(3) clays and sands of Quaternary and Tertiary age, granite and kaolin, 10-90 ppm V; (4) uppermost and lowermost Paleozoic shales, more Tertiary and fewer Quaternary rocks than group 3, $100_{-}$ $900 \mathrm{ppm} \mathrm{V}$; and (5) Dictyonema and most of the Olenidian shales, >1,000 ppm V. Black Paleozoic shales showed the following $\mathrm{V}$ contents (in ppm): Cambrian: Lower alum shale, Paradoxides, 240; Olenus, Agnostus pisiformis zone, 500; Olenus, Orusia zone, 1,100; Olenus, Eurycare latum zone, 1,000, 1,100; Olenus, Peltura zone, 800; Olenus, Acerocare zone, 1.600; Ordovician: Dictyonema shale 1,000-2,100; middle Dicellograptus shale 130; Trinucleus shale 120; Silurian; Rastrites shale 250270 ...EBT

00031 Borchert, Herman; Krejci-Graf, Karl. Spurenmetalle in Sedimenten und ihren Derivaten [Trace metals in sediments and their derivatives (in German; English abs.)]: Bergbauwissenschaften, v. 6, p. 205-215, 1959.

The contents of $\mathrm{Ti}, \mathrm{V}, \mathrm{Cr}, \mathrm{Mo}, \mathrm{Mn}, \mathrm{Co}, \mathrm{Ni}$, and $\mathrm{U}$ in many samples of sedimentary rocks, coals, graphites, metamorphic rocks, bituminous rocks, and petroleum were determined. Factors controlling the enrichment of trace elements in sedimentary rocks and petroleum are discussed. Semiquantitative spectrographic analyses show (in ppm): Gyttja shales: Ordovician, Ti nd-10,000, V 10-500, Cr .50-500, Mo nd $-50, \mathrm{Mn} \operatorname{tr}-500$, Co tr-50, Ni 10-100; Silurian, Ti 100-500, V 100-500, Cr tr, Mo, nd, Mn 50-500, Co nd, Ni tr-50; middle Zechstein, V 100-500, Cr 100-500, Mo tr, Mn 10-50, Cotr, Ni 100-500; Lias $\epsilon$, Ti 1,000-5,000, V 100-500, Cr 100 500 , Mo tr, Mn 1,000-5,000, Co 50-100, Ni 50-100; Lutetian, Ti 5,000-10,000, V 500-1,000, Cr 500-1,000, Motr, Mn 1,000-5,000, Co 50-100, Ni 500-1,000; Tertiary, Ti 1,000-5,000, V 5-10, Cr 50-100, Mo 5-10, Mn 10-50, Co nd, Ni 5-10; in sapropel shales: Ordovician Dictyonema shales, Ti $5,000-10,000, \mathrm{~V} 1,000-5,000, \mathrm{Cr} 10-100$, Mo $10-500, \mathrm{Mn} 50-1,000$, Co $50-100$, Ni 100-500; Silurian graptolitic shales, Ti 100-10,000, V 500-5,000, Cr tr-500, Mo nd-50, Mn 5-500, Co nd-500, Ni tr-1,000; Zechstein, Ti 5,000-10,000, V 100-1,000, Cr 50-500, Mo 10-100, Mn 50-10,000, Co 10-500, Ni 50-500; upper Lias, Ti 5,000-10,000, V 100-500, Cr 100-500, Mo tr, Mn 100-500, Co 100-500, Ni 100-500.-EBT

00033 Borisenko, L. A.; Saukov, A. A. Geochemical cycle of gallium: Internat. Geol. Cong., 21 st, Copenhagen, Rept., Pt. 1, Geochemical cycles, p. 96-105, 1960.

Study of Ga distribution in shales has shown that $\mathrm{Ga}$ is more concentrated in freshwater shales $(20-35 \mathrm{ppm})$ than in marine shales $(7-10 \mathrm{ppm})$. This is explained by the higher $\mathrm{Al}, \mathrm{Si}$, and $\mathrm{Ga}$ contents in fresh water than in sea water. The very low contents of $\mathrm{Al}, \mathrm{Si}$, and $\mathrm{Ga}$ in sea waters must mean that these elements are precipitated when fresh waters enter the sea. Consequently, low Ga concentrations 
in shales may serve as a geochemical indicator of marine facies.-Authors' abs. condensed.

00032 Borisenko, L. F. Skandiy. Osnovye cherty geokhimii, mineralogii, i geneticheskiye tipy mestorozhdeniy [Scandium. Main features of the geochemistry, mineralogy and genetic types of deposits]: Akad. Nauk SSSR, Inst. Mineralogii, Geokhimii i Kristallokhimii Redkikh Elementov, Trudy, 1961; English translation: Scandium, its geochemistry and mineralogy: New York, Consultants Bur. Enterprises, Inc., 78 p., 1963.

$\mathrm{Sc}$ is present in appreciable amounts in some pelagic clays and bauxites, but has not been detected in limestones, dolomites and manganese oxides. Clays, black coaly shales, coal ashes, petroleum ashes and bitumens are enriched in $\mathrm{Sc}$ as much as 10 or more times the crustal abundance $(5$ to $6 \mathrm{ppm})$. Sc is evidently almost completely removed from sea water in benthic sediments. During sedimentation, organic material is not only important as a reducing agent, but also in the sorption of rare elements such as Sc and the rare earths.-EBT

00034 Borneman-Starynkevich, I. D.; Borovik, S. A.; Borovskiy, I. B. Redkiye zemliv rasteniyakh i pochvakh [Rare earths in plants and soils (in Russian)]: Akad. Nauk SSSR Doklady, v. 30, no. 3, p. 227-231, 1941.

Analyses of plants and soils for rare earth elements are presented. Sequanian clays [of Late Jurassic age] were also analyzed and were found to contain $110 \mathrm{ppm}$ rare earths ( $\mathrm{La} 19.7$ percent, $\mathrm{Ce} 42.7, \operatorname{Pr} 8.3, \mathrm{Nd} 20.7, \mathrm{Sm} \mathrm{1.7,} \mathrm{Gd} \mathrm{2.2,} \mathrm{Dy} \mathrm{1.1,} \mathrm{Er} \mathrm{0.2,}$ and $Y 3.4$ percent of the total rare earths).--EBT

Borovik, S. A. See Borneman-Starynkevich, I. D. 00034

Borovskiy, I. B. See Borneman-Starynkevich, I. D. 00034

Botez-Postelnicu, Cornelia. See Savul, Mircea. 00232

Botez-Postelnicu, Cornelia. See Savul, Mircea. 00233

00038 Brandenstein, M.; Janda, I.; Schroll, E. Seltene Elemente in österreichischen Kohlen- und Bitumengesteinen [Rare elements in Austrian coals and bituminous rocks (in German)]: Tschermaks Mineralog. u. Petrog. Mitt., v. 7, no. 3, p. 260285,1960 .

A double-arc emission spectrograph was used to analyze 119 samples of carbonaceous rocks, peat, oil shale, and other organic sediments from Austria for the following elements (ranges of element contents found in carbonaceous shales, carbonaceous marls, combustible shales, an underclay, Triassic Cardita Shale, and black oil shale are given in ppm): Ge nd-13, Be nd-11, Cr 6-224, As nd-345, Sb nd-6, Bi nd-4.1, Ag nd -0.5, Cu 0.5-50, $\mathrm{Pb}$ nd $-100, \mathrm{Zn}$ nd-110, $\mathrm{Hg}$ nd-tr, Co nd-43, Ni nd-220, Mo nd -85 , V nd-1,100, Ga nd-50, Tl nd-4, Sn nd -22, Ti nd$8,000, \mathrm{Mn} \mathrm{21-700}$ and ash 10.3-82.3 percent (no ash content given for Cardita Shale).-EBT

00035 Breger, I. A. Radioactive equilibrium in ancient marine sediments: Geochim. et Cosmochim. Acta, v. 8, p. 63-73, 1955.

Radioactive equilibrium in 8 marine sedimentary formations was studied by direct determinations of $U, R a$, and Th. Alpha-particle counting was also done to crosscalibrate thick-source counting techniques. Maximum deviation from radioactive equilibrium noted is 11 percent - indicating probable equilibrium in all formations analyzed. Th contents correspond well to the average values reported in the literature, but $U$ content of marine sediments may be higher than previously reported. As much as 14 times more $U$ than Th occurs in the formations studied, but the Th content never exceeds the $U$ content. Proximity of depositional environment to landmass may influence the concentration of $U$ in a marine sediment, but it does not affect Th. Contents in the Upper Cretaceous Tuscaloosa Formation are (standard deviation in parentheses), organic matter 1.25 percent, U $2.81(0.16)$ ppm, Th $0.2 \mathrm{ppm}$, Ra $0.83 \times 10^{-6}\left(0.00 \times 10^{-6}\right) \mathrm{ppm}$; in the Upper Cretaceous Eagle 


\section{BIBLIOGRAPHY OF MINOR ELEMENTS IN BLACK SHALES}

Ford Shale, organic matter 1.25 percent, U $2.25(0.01) \mathrm{ppm}$, Th --, Ra $0.65 \times 10^{-6}$ $\left(0.01 \times 10^{-6}\right) \mathrm{ppm}$; in the Upper Cretaceous Eutaw Formation, lower part, organic matter 1.25 percent, $U 2.53(0.05) \mathrm{ppm}$, Th -- , Ra $0.77 \times 10^{-6}\left(0.04 \times 10^{-6}\right) \mathrm{ppm}$; in Miocene nodular shale from California, organic matter 7.25 percent, $U 14.4(0.30)$ $\mathrm{ppm}$, Th $3.6 \mathrm{ppm}$, Ra $3.96 \times 10^{-6}\left(0.10 \times 10^{-6}\right) \mathrm{ppm}$; in Upper Devonian Antrim Shale, organic matter 7.25 percent, $U 17.5(0.40) \mathrm{ppm}$, Th $2.8 \mathrm{ppm}, \mathrm{Ra} 5.15 \times 10^{-6}$ $\left(0.27 \times 10^{-6}\right) \mathrm{ppm}$.- Author's abs., modified.

00036 Breger, I. A.; Brown, Andrew. Kerogen in the Chattanooga Shale: Science, v. 137, no. 3525 , p. $221-224,1962$.

The Chattanooga Shale [of Devonian and Mississippian age] contains insoluble organic matter (kerogen) derived from terrestrial (humic) and from marine (sapropelic) sources. Kerogen from sapropelic sources contains more hydrogen than kerogen from humic sources. Thus the $\mathrm{H}$ content of the sapropelic contribution, and of the kerogen, increases toward that part of a shale most likely to be a source bed for petroleum. U content in the shale is derived from the adjoining landmass. $\mathrm{U}$ Content ranges from 9 to $92 \mathrm{ppm}$ in samples from Tennessee and adjoining States. Most of the organic matter in the Chattanooga Shale is of terrestrial origin. Authors' abs., modified.

00037 Breger, I. A.; Schopf, J. M. Germanium and uranium in coalified wood from upper Devonian black shale: Geochim. et Cosmochim. Acta, v. 7, p. 287-293, 1955.

Microscopic study of black, vitreous, carbonaceous material from the Chattanooga Shale in Tennessee and the Cleveland Member of the Ohio Shale in Ohio has revealed coalified woody plant tissue, some of which has been identified with the genus Callixylon. Similar material has been reported as "bituminous" or "asphaltic" stringers. Spectrographic analysis of ash of the wood has shown unusually high contents of $\mathrm{Ge}, \mathrm{U}, \mathrm{V}$, and $\mathrm{Ni}$. The inverse relationship between $\mathrm{U}$ and $\mathrm{Ge}$ in the ash and ash contents of various samples shows an association of these elements with organic constituents of coal. From geochemical evidence it seems most probable that the wood was Ge-bearing at the time it was floated into the basins of deposition. Once within the marine environment, the material probably absorbed $\mathrm{U}$ with the formation of organo-uranium compounds such as exist in coals. Semiquantitative spectrographic analyses showed (range in ppm): ash (77.32 percent) of Chattanooga Shale, 1-5, Yb, Be, Ag; 10-50, Y, Pb, Sc, Ge: 50-100, $\mathrm{V}, \mathrm{Ga}, \mathrm{La}, \mathrm{Zr} ; 100-500$, Co, B, Cu, Sr, Cr, Mo; 1,000-5,000, Ca, Na, Ti, Ba. Ash (1.27 percent) of coal from Chattanooga Shale, 10-50, Ga, Sc, Be; 50-100, $\mathrm{Yb} ; 100-500, \mathrm{Co}, \mathrm{Sn}, \mathrm{Zr}, \mathrm{Mn}, \mathrm{Zn} ; 500-1000, \mathrm{Y}, \mathrm{Pb}, \mathrm{Ba} ; 1,000-5,000, \mathrm{Na}, \mathrm{B}, \mathrm{Cu}$, $\mathrm{Ti}, \mathrm{Cr}, \mathrm{Mo}, \mathrm{Sr} ; 5,000-10,000, \mathrm{Ni}, \mathrm{U}, \mathrm{Mg} ; 10,000-50,000, \mathrm{Ge}, \mathrm{Al}, \mathrm{Ca}, \mathrm{V}$. Ash $(1.7$ percent) of coal from Cleveland Member, 5-10, Be; 10-50, La, Ga, Sc; 50-100, Yb; 100-500, Mo, Sn, Pb, Zr; 500-1,000, Ba, B, Na, Mn, Sr, Y; 1,000-5,000, Cu, Cr, $\mathrm{Ni}, \mathrm{Ti}, \mathrm{U} ; 5,000-10,000$, Co, Mg, Zn; 10,000-50,000, V, Ge.-Authors' abs., modified.

00039 Breger, I. A.; Brown, Andrew. Distribution and types of organic matter in a barred marine basin: New York Acad. Sci. Trans., ser. 2, v. 25, no. 7, p. 741$755,1963$.

Samples of the Devonian Chattanooga Shale from Tennessee and adjoining States range in $U$ content from 8 to $86 \mathrm{ppm}$ and in organic isolate (moisture and ash free) from 5.9 to 29.3 percent. The $U$ and organic matter in the Chattanooga Shale is of terrestrial origin.-EBT

00069 Brimhall, W. H. Progress report on selenium in the Manning Canyon Shale, central Utah: Brigham Young Univ. Geology Studies, v. 10, p. 104-120, 1963.

Se is present in unusual concentrations in shaly strata throughout the 1,600 -foot thickness of the Manning Canyon Shale of Carboniferous age in the Oquirrh Range, Utah. High concentrations of Se are most common in dark-colored, carbonaceous, calcareous, soft, usually gypsiferous, and often iron-oxide stained or pyritic shale. Such rocks, interbedded with shaly limestone or nearly pure limestone, have a mean content of $18 \mathrm{ppm} \mathrm{Se}$ with a standard deviation of $8 \mathrm{ppm}$. Possibly the Se is derived from organic matter, reconstituted in part as a sulfide, and subsequently oxidized 
to selenite or selenate. The concentration of $\mathrm{Se}$ is more allied with marine or brackish water processes than with terrestrial processes. - Author's abs., condensed.

Brown, Andrew. See Breger, I. A. 00036

Brown, Andrew. See Breger, I. A. 00039

00070 Burton, J.D.; Culkin, F.; Riley, J. P. The abundances of gallium and germanium in terrestrial materials: Geochim. et Cosmochim. Acta, v. 16, p. 151-180, 1959.

Ge was determined by a spectrographic method using phenylfluorone and $\mathrm{Ga}$ by a specific spectrophotometric method in more than 200 minerals, rocks and sediments, and in sea water. The crustal abundance of $\mathrm{Ge}$ is about $1.7 \mathrm{ppm}$; of $\mathrm{Ga}, 16.9 \mathrm{ppm}$. Average amounts of $\mathrm{Ge}$ in metamorphic rocks, shales, and red clays are close to the crustal abundance; the $\mathrm{Ge}$ in pelagic sediments is contained entirely in the clay fraction. Residual sandstones and other silica-rich sedimentary rocks are also generally poor in Ga. Pelagic clays from the Pacific, Atlantic and Indian Oceans contained an average $22.4 \mathrm{ppm} \mathrm{Ga}$. Black shales analyzed include (in ppm): Cambrian Tremadoc, Merionethshire; Ge 3.2, Ga 21.3; Carboniferous Rhydymwyn, Flintshire, Ge 0.9, Ga 2.8; and the Rhaetic Jurassic, Gloucestershire, Ge 1.5, Ga 4.3-Authors' abs., modified.

\section{Byers, H. G. See Edgington, Glen. 00047}

00061 Byers, H. G. Selenium occurrence in certain soils in the United States, with a discussion of related topics: U.S. Dept. Agriculture Tech. Bull. 482, 47 p., 1935.

All analyzed samples of the Pierre Shale of Late Cretaceous age from South Dakota contained Se; the amounts ranged from a trace to $100 \mathrm{ppm}$. Generally Se content was less than $10 \mathrm{ppm}$ in the upper part of the Pierre and more than $10 \mathrm{ppm}$ in the lower part. Samples of shales, soils, and plants from Nebraska, Wyoming, Colorado, Kansas, Oklahoma, New Mexico, Arizona, and Utah were also analyzed. Se contents ranged from a trace to $31 \mathrm{ppm}$.-EBT

00062 Byers, H. G.; Lakin, H. W. Selenium in Canada: Canadian Jour. Research, v. 17 , sec. B, p. $364-369,1939$.

The existence of an enormous area of seleniferous soil is shown by the results of a reconnaissance examination of parts of Alherta, Saskatchewan, and Manitoba Provinces of Canada. Shales exposed include St. Mary River, Fox Hills, Bearpaw, Belly River, Pakowki, and Milk River Formations which correspond in a general way with the various subdivisions of the Pierre Shale of Late Cretaceous age in South Dakota. The Se content of the shales sampled ranged from 0.3 to $3 \mathrm{ppm}$.EBT

00063 Byers, H. G.; Miller, J. T.; Williams, K. T.; Lakin, H. W. Selenium occurrence in certain soils in the United States with a discussion of related topics. Third report: U.S. Dept. Agriculture Tech. Bull. 601, 74 p., 1938.

Additional data on Se in water, vegetation, soils, and rocks and on the chemistry of Se are presented. Probably the concentration of Se in sedimentary rocks, especially shales, is due to absorption of volcanic Se and deposition along with other shale materials. Samples from a section of the Greenhorn Formation near Pueblo, Colo., contained 0.1-8 ppm; dark-gray to black shales from that section contained $0.1-2.5 \mathrm{ppm}$ Se. Samples of the Smoky Hill Member of the Niobrara Formation from Kansas contained 6-14 ppm Se. In eastern Colorado samples of the Niobrara contained 3.5-156 ppm. Samples of the Pierre Shale from New Mexico contained $0.8-2.5 \mathrm{ppm}$. A sample of carbonaceous shale from the Mancos Shale in Utah contained $12 \mathrm{ppm} \mathrm{Se}$. All of these formations are Late Cretaceous in age.-EBT

00071 Byers, H. G. Selenium occurrence in certain soils in the United States with a discussion of related topics. Second report: U.S. Dept. Agriculture Tech. Bull. 530,78 p., 1936. 


\section{BIBLIOGRAPHY OF MINOR ELEMENTS IN BLACK SHALES}

The existence of large areas of land containing sufficient Se to produce toxic vegetation has been demonstrated in the area surrounding the Black Hills, S. Dak., in western Colorado in parts of the valleys of the Uncompahgre, Gunnison, and Colorado Rivers, in part of western Kansas, and in certain parts of Montana. Data are presented that indicate a close relationship between the Se content of soil and of the soil parent material. The parent material so far demonstrated as producing toxic soils appears to be limited to the lower part of the Pierre Shale and the upper part of the Niobrara Formation and other correlative Cretaceous formations. Se contents in shale samples range from 0.2 to $22 \mathrm{ppm}$; the range in soil samples and in concretions is much greater.-EBT

Byers, H. G. See Lakin, H. W. 00179

Byers, H. G. See Lakin, H. W. 00202

Byers, H. G. See Williams, K. T. 00315

00072 Cadman, W. H. The oil shale deposits of the world and recent developments in their exploitation and utilization, reviewed to May 1947: Inst. Petroleum Jour. [London], v. 34, no. 290, p. 109-132, 1948.

A brief survey is given of the oil-shale deposits in various countries, including some of the wartime and more recent developments in Great Britain, France, Estonia, Sweden, Spain and Portugal, Italy, Czechoslovakia, USSR, Turkey, Bulgaria, Germany, Japan. Australia, New Zealand, Canada, South Africa, India and Burma, Brazil, and the United States of America. A general description is given of the nature and chemical composition of the oil shales and some oil-shale products. Traces of As have been found in Scottish oil shale equal to $5.6 \mathrm{ppm}$ by weight calculated as $\mathrm{As}_{2} \mathrm{O}_{3}$. Some of the oil shales of Sweden contain as much as 0.4 percent by weight $\mathrm{V}$. The content of $U$ in a Swedish oil-shale deposit (Norrtorp) ranges from 30 to $270 \mathrm{ppm}$.--Author's abs., modified.

Cameron, E. N. See Warner, L. A. 00339

00060 Campbell, F. A.; Williams, G. D. Chemical composition of shales of Mannville Group (Lower Cretaceous) of Central Alberta, Canada: Am. Assoc. Petroleum Geologists Bull., v. 49, no. 1, p. 8I-87, 1965.

The $\mathrm{X}$-ray fluorescence method was used to analyze 113 shales; 7 from the Upper Devonian Calmar Formation, 98 from the Lower Cretaceous Mannville Group, and 8 from the Lower Cretaceous Joli Fou Formation. The average composition of the shales studied is 64.83 percent $\mathrm{SiO}_{2}, 2.66$ percent $\mathrm{MgO}, 15.72$ percent $\mathrm{Al}_{2} \mathrm{O}_{3}$, 2.50 percent $\mathrm{K}_{2} \mathrm{O}, 2.42$ percent $\mathrm{CaO}, 5.08$ percent $\mathrm{Fe}_{2} \mathrm{O}_{3}, 97 \mathrm{ppm} \mathrm{Rb}$, and $210 \mathrm{ppm}$ $\mathrm{Sr}$. The $\mathrm{Rb} / \mathrm{Sr}$ ratio of 0.46 is in good agreement with that suggested for shales by other workers. The $\mathrm{Rb} / \mathrm{K}$ varies from about 0.004 for shales formed in a brackish environment, to 0.006 for normal marine shales.-Authors' abstract

00064 Canney, F. C. Some aspects of the geochemistry of potassium, rubidium, cesium, and thallium in sediments [abs.]: Geol. Soc. America Bull., v. 63, no. 12, pt. 2, p. $1238,1952$.

Determinations of the $\mathrm{Rb}, \mathrm{Cs}$, and $\mathrm{Tl}$ contents of 323 samples from 10 sedimentary formations were made by spectrochemical methods. The precision of the spectrochemical methods employed, expressed as standard deviations, was \pm 4.5 percent for $\mathrm{Rb}, \pm 8.2$ percent for $\mathrm{Cs}$, and \pm 8.8 percent for $\mathrm{Tl}$. Average abundances of these elements in argillaceous sediments are (in ppm): $\mathrm{Rb}_{2} \mathrm{O}, 310 ; \mathrm{Cs}_{2} \mathrm{O}, 8.1$; and $\mathrm{Tl}_{2} \mathrm{O}, 0.38$. $\mathrm{Tl}$ is usually enriched in highly organic sediments. The order of relative enrichment of these elements in sediments is normally: Cs $>\mathrm{Rb}>\mathrm{K}>\mathrm{Tl}$. The order of relative enrichment found is in excellent agreement with the theory that the adsorption affinity of a cation from aqueous solutions is proportional to the value of the positive electrostatic potential existing at the surface of the hydrated ion. [Note: The Rb values are high (F. C. Canney, 1965, oral commun.].-Author's abs., condensed. 
Carlier, A. See Grimbert, Arnold. 00107

Carlisle, Donald. See Gunning, H. C. 00095

00065 Carr, M. H.; Turekian, K. K. The geochemistry of cobalt: Geochim. et Cosmochim. Acta, v. 23, p. 9-60, 1961.

Co was determined in many geologically interesting materials using the combined techniques of emission spectrography and neutron activation analysis. Neutron activation was used to analyze standards for the emission spectrograph and materials low in Co. In sediments most of the $C_{o}$ is in the argillaceous fraction and seems to follow $\mathrm{Fe}$ and $\mathrm{Mn}$. Co accumulations in deep-sea sediments are supplied by detritally associated Co and dissolved Co from surface runoff rather than by volcanic exhalations. The crustal abundance of $C_{0}$ is calculated as $27 \mathrm{ppm}$; shales average 19. Analyses of samples of 70 shales, including black shales, ranging in age from Cambrian through Cretaceous, show the range of Co contents to be 4 to $115 \mathrm{ppm}$.Authors' abs., modified.

Chase, J. W. See Coryell, C. D. 00067

00073 Chentsov, 1. G. Selen $v$ otlozheniyakh paleogena Sredney Azii [Selenium in Paleogene sediments of Central Asia (in Russian)]: Akad. Nauk SSSR, Inst. Geologii rudnykh mestorozhdeniy, petrografii, mineralogii i geokhimii, Trudy, v. 28, p. 83-89 [English translation by Michael Fleischer, 1960, written commun.], 1959.

Widespread Se content was discovered in sediments of Paleogene age in northeastern Fergana in central Asia, especially in rocks enriched in sulfides and organic matter. Analyses of soils on outcrops of Paleogene rocks show Se contents ranging from 1 to $10 \mathrm{ppm}$. Samples from the bituminous limestone horizons contained as much as $100 \mathrm{ppm} \mathrm{Se.} \mathrm{In} \mathrm{the} \mathrm{bituminous} \mathrm{limestone} \mathrm{horizon} \mathrm{"} \mathrm{m}$ " of the Turkestan stage, Se is closely associated with organic matter, iron sulfides, various compounds of tri-, quadri-, and quinquevalent $\mathrm{V}$, and with other minerals.-EBT

00059 Chilean Iodine Educational Bureau. Geochemistry of iodine; annotated bibliography 1825-1954: London, Stone House, 150 p., 1956.

This book consists of three principal sections: an annotated bibliography of 400 scientific papers known to contain quantitative or qualitative facts about the presence of $I$ in the inorganic world: a succession of 20 tables in which these data have been systematically classified; and a review which attempts to summarize and interpret the analytical finds thus assembled. The average of all available data shows the I content of shales and argillites to be $2.180 \mathrm{ppm}$.--EBT

00066 Chow, T. J.; Patterson, C. C. The occurrence and significance of lead isotopes in pelagic sediments: Geochim. et Cosmochim. Acta, v. 26, p. 263-308, 1962.

About two-thirds of the $\mathrm{Pb}$ in all Pleistocene pelagic sediments was chemically precipitated from sea water. The remaining one-third was transported as a constituent of solid particles. The rate of chemical deposition of $\mathrm{Pb}$ tends to be uniform everywhere: the rate of mechanical deposition varies considerably. Dark clays, deposited at a rate of $0.03 \mathrm{~g}$ per $\mathrm{cm}^{2}$ per 1,000 years, contain $88 \mathrm{ppm} \mathrm{Pb}$, of which $74 \mathrm{ppm}$ is contained in authigenic minerals and is derived from $\mathrm{Pb}$ dissolved in sea water, $13 \mathrm{ppm}$ is contained in clay minerals and carbonate, and $1 \mathrm{ppm}$ is in igneous minerals and opal. Light-colored sediments contain about $42 \mathrm{ppm} \mathrm{Pb}$ and oozes, $23 \mathrm{ppm}$. The $\mathrm{Pb}$ concentration in all pelagic sediments is about 24 $40 \mathrm{ppm}$. Isotopic data are discussed in detail.-EBT

00068 Cissarz, Arnold. Quantitativ-specktralanalytische Untersuchung eines Mansfelder Kupferschieferprofils [Quantitative spectroanalytical investigation of a Mansfeld Kupferschiefer profile (in German)]: Chemie der Erde, v. 5, p. 48-75, 1930.

A section of the Mansfeld Kupferschiefer was analyzed spectrographically and 42 different elements were found. The spectrographic method is described in detail. 


\section{BIBLIOGRAPHY OF MINOR ELEMENTS IN BLACK SHALES}

The metals were in two principal groups, one with $\mathrm{Cu}$, the other with $\mathrm{Zn}$. Those elements found with $\mathrm{Cu}$ were: $\mathrm{Co}, \mathrm{Ni}, \mathrm{V}, \mathrm{Ag}, \mathrm{Au}, \mathrm{Pt}, \mathrm{Pd}, \mathrm{Ir}$, and $\mathrm{Mo}$; those with $\mathrm{Zn}$ were: $\mathrm{Pb}, \mathrm{Cd}, \mathrm{Mn}, \mathrm{Sn}, \mathrm{W}, \mathrm{Cr}$, and subordinate $\mathrm{As}, \mathrm{Sb}$ and $\mathrm{Bi}$. $\mathrm{Cu}$ values were highest in the Feine Lette, Schwarzen Berge, and Grobe Lette beds, which are all rich in bitumens; the $\mathrm{Zn}$ values were highest in the Schieferkopf bed, which is bitumen poor. The following contents were found by spectrographic analysis (ranges in ppm estimated from fig. 2): $\mathrm{Cu} 100->10,000, \mathrm{Ni} 5-100$, Co $1-100, \mathrm{~V}$ 5-200, Mo <1-70, Au $<0.1-0.5$, Ag 1-15, Zn 30-7,000, Pb 3-700, Cd $<1-200$ EBT

00058 Clarke, F. W. The data of geochemistry, 5th ed.: U.S. Geol. Survey Bull. 770, 841 p., 1924.

Analyses of igneous, metamorphic, and sedimentary rocks, minerals, ores, volcanic gases, waters, and the atmosphere are presented with discussion of geochemistry and chemistry of the world. A composite analysis of 51 Paleozoic shales showed the following trace elements: $\mathrm{TiO}_{2} 0.76$ percent, $\mathrm{MnO}$ tr, $\mathrm{BaO} 0.04$ percent, $\mathrm{Li}_{2} \mathrm{O}$ tr. A black Devonian shale from Morenci district, Ariz., contained: $\mathrm{TiO}_{2} \mathbf{0 . 6 6}$ percent, $\mathrm{MnO} 0.07, \mathrm{ZnO} 0.03, \mathrm{BaO} \operatorname{tr}, \mathrm{Li}_{2} \mathrm{O}$ tr. Analyses of 2 black roofing-slate samples, one from Benson, Vt., the other from Slatington, Pa., showed these trace elements: $\mathrm{TiO}_{2} 0.79,0.78$ percent, $\mathrm{MnO} 0.16,0.09$ percent, $\mathrm{BaO} 0.08,0.08$ percent.EBT

00074 Clarke, F. W.; Washington, H. S. The composition of the earth's crust: U.S. Geol. Survey Prof. Paper 127, 117 p., 1924.

Included in this calculation of the composition of the earth's crust is an analysis of a composite sample of 78 shales. The organic C content was found to be 0.80 percent and the trace elements found were (in ppm): $\mathrm{TiO}_{2} 6,500, \mathrm{BaO} 500, \mathrm{MnO}$ tr., $\mathrm{LiO}_{2}$ tr.-EBT

00075 Cloud, P. E., Jr.; Gruner, J. W.; Hagen, Hannelore. Carbonaceous rocks of the Soudan Iron Formation (Early Precambrian): Science, v. 148, no. 3678, p. 1713$1716,1965$.

The Soudan Iron Formation occurs in northeastern Minnesota as large sedimentary lenses interstratifed with basalt flows and tuff layers, all more than 2.7 billion years old. Some thin layers and lenses of the Soudan rocks are so rich in carbon that they resemble impure graphitic coal, including pyrite balls 1 to $3.5 \mathrm{~cm}$ in diameter such as are common in younger coals. The pyrite balls contain microstructures of possible biologic origin. The $C^{13}: C^{12}$ and $S^{34}: S^{32}$ ratios and minor-element composition are consistent with this interpretation. Hydrocarbons of presumed vital origin are also present, although they may not be endemic to the rock. Minor element contents in rocks from the Soudan mine are (in ppm) in carbon-rich rock (organic matter 24.2 percent): $\mathrm{V}_{2} \mathrm{O}_{5} 73, \mathrm{~Pb} 150, \mathrm{U} 3.2$; in pyritic rock (organic matter 20.2 percent): $\mathrm{V}_{2} \mathrm{O}_{5} 68, \mathrm{~Pb} 210, \mathrm{U} 6.5$; and in siliceous rock (organic matter 2.4 percent): $\mathrm{V}_{2} \mathrm{O}_{5} 20, \mathrm{~Pb} 50$, and $\mathrm{U} 0.87$.- EBT

00054 Cobb, J. C.; Kulp, J. L. Isotopic geochemistry of uranium and lead in the Swedish kolm and its associated shale: Geochim. et Cosmochim. Acta, v. 24, p. 226-249, 1961.

The $\mathrm{U}$ and $\mathrm{Pb}$ concentrations and isotopic composition in samples of kolm and associated black shale from the Peltura beds (Franconian Stage) of the Upper Cambrian of Sweden have been determined by isotope dilution techniques. The middle Upper Cambrian Swedish alum shales contain the highest amounts of $U$ reported for any black shale. The $U$ concentration is as high as $6,500 \mathrm{ppm}$ in small organic-rich pods called "kolm" and is about $200 \mathrm{ppm}$ for the shale itself. The kolm contains as much as 80 percent organic matter compared to 30 percent for the shale. $\mathrm{Pb}$ content in the kolm ranges from 177 to $363 \mathrm{ppm}$; in the black shale, from 27.8 to $44.9 \mathrm{ppm}$.-EBT

00055 Conant, L. C.; Swanson, V. E. Chattanooga Shale and related rocks of central Tennessee and nearby areas: U.S. Geol. Survey Prof. Paper 357, 91 p., 1961. 
The age, stratigraphy, distribution, composition, paleogeography, paleontology, sedimentation, environment of deposition, and economic geology of the Chattanooga Shale of Late Devonian age are discussed. The average $\mathrm{P}_{2} \mathrm{O}_{5}$ content of the Chattanooga Shale is 0.12 percent. The U content averages $60 \mathrm{ppm}$ in the Gassaway Member, $10 \mathrm{ppm}$ in the upper unit of the Dowelltown Member, and $30 \mathrm{ppm}$ in the lower unit of the Dowelltown.--EBT

00056 Correns, C. W. The geochemistry of the halogens, Chap. 7 in Ahrens, L. H., Rankama, Kalervo, and Runkorn, S. K., eds., Physics and chemistry of the earth: New York; McGraw-Hill Book Co., Inc., v. 1, p. 181-233, 1956.

The geochemistry of $\mathrm{F}, \mathrm{Cl}, \mathrm{Br}$, and $\mathrm{I}$ is discussed and an extensive bibliography given. Coarse clastic sediments contain less than average amounts of $\mathrm{F}$ and $\mathrm{Cl}$, but about the same amounts of $\mathrm{Br}$ and $\mathrm{I}$ as in igneous rocks. Because of clay mineral content, pelites may contain more $\mathrm{F}$ and less $\mathrm{Cl}$ than the average abundances. $\mathrm{Br}$ and $\mathrm{I}$ contents increase in clay sediments rich in organic matter. The following contents are reported in pelites (in ppm): Diluvial clay, Mecklenburg, $\mathrm{F} 630, \mathrm{Cl} 220, \mathrm{Br} 1.7, \mathrm{P}_{2} \mathrm{O}_{5}$ 970; Septarian clay, middle Oligocene, Mecklenburg, $\mathrm{F} 990, \mathrm{Cl} 450, \mathrm{Br} 58, \mathrm{P}_{2} \mathrm{O}_{5} 870$; Lias clay, Mecklenburg, $\mathrm{F} 760, \mathrm{Cl} 210, \mathrm{Br} 5.2$, $\mathrm{P}_{2} \mathrm{O}_{5}$ 1,270; laminated marl, Upper Muschelkalk, Göttingen, $\mathrm{F} 1,780, \mathrm{Cl} 210, \mathrm{Br}$ $5.5, \mathrm{P}_{2} \mathrm{O}_{5}$ 1,370; clay bed in Middle Bunter sandstone, Lower Saxony, F 1,180, Cl $170, \mathrm{Br} 3, \mathrm{P}_{2} \mathrm{O}_{5} 820$; Wissenbach shale, Middle Devonian, Hartz, $\mathrm{F} 950, \mathrm{Cl} 50$, $\mathrm{Br}$ 4.2, $\mathrm{P}_{2} \mathrm{O}_{5}$ 1,230; green Keuper clay, south of Göttingen, $\mathrm{F} \mathrm{690,} \mathrm{Cl} 370, \mathrm{Br} 4.4$, $\mathrm{P}_{2} \mathrm{O}_{5} 780$.-

00057 Correns, C. W. Uber die Geochimie des Fluors und Chlors [On the geochemistry of fluorine and chlorine (in German)]: Neues Jahrb. Mineralogie Abh., v. 91, p. 239-256, 1957.

The Kulmkieselschiefer contained $\mathrm{F}$ in amounts ranging from 210 to $830 \mathrm{ppm}$ with a mean of $510 \mathrm{ppm}$; and $\mathrm{Cl}$ ranging from 90 to $210 \mathrm{ppm}$. F contents in Japanese clay ranged from 200 to $1,100 \mathrm{ppm}$ and in German clay from 550 to $1,780 \mathrm{ppm}$. The $\mathrm{Cl}$ contents in the German clay ranged from 50 to $450 \mathrm{ppm}$.--EBT

00067 Coryell, C. D.; Chase, J. W.; Winchester, J. W. A procedure for geochemical interpretation of terrestrial rare-earth abundance patterns: Jour. Geophys. Research, v. 68, no. 2, p. 559-566, 1963.

A procedure for geochemical interpretation of rare-earth abundances in rocks and minerals is presented. The ratio of each rare-earth abundance in the sample to the corresponding value in chondritic meteorites (on logarithmic scale) is plotted as a function of atomic number. Normalization to chondrites compensates for element-to-element irregularities and reveals small relative abundance variations among neighboring rare earths as a result of natural processes. It is shown that increased order occurs, permitting interpolations and extrapolations to be made with fair confidence, and systematic rare-earth abundance patterns are made apparent. The usefulness of the procedure is discussed using several examples from existing literature, including Minami's composite (1935b) shale samples.-Authors' abs., modified.

00076 Couderc, J. M. Les schistes bitumineux du Lias en Wurtemberg du Sud [The Liassic bituminous shales of south Wurtemberg (in French)]: Inst. Petroleum, Oil Shale and Cannel Coal, v. 2, p. 38-75, 1951.

Included in this discussion of the bituminous shales of Liassic age from Wurtemberg is a review of their trace-element contents, taken partly from the literature and partly from unpublished analyses. In the residue of shale from Schömberg 0.20.3 percent $\mathrm{B}_{2} \mathrm{O}_{3}$ was found. The shale from Holzmaden contained an average $500 \mathrm{ppm} \mathrm{V}$. The Posidonienschiefers in the German Lias contained $20 \mathrm{ppm} \mathrm{Ni}$, $20-50 \mathrm{ppm} \mathrm{Mo}$, and $50-70 \mathrm{ppm} \mathrm{V}$. Other analyses for major elements and of the bituminous material are given.-EBT

00053 Crouse, C. S. The precious metal content of the black Devonian shales of Kentucky, in Thiessen, Reinhardt, White, David, and Crouse, C. S., Oil shales of Kentucky: Kentucky Geol. Survey, ser. 6, v. 21, p. 49-58, 1925. 


\section{BIBLIOGRAPHY OF MINOR ELEMENTS IN BLACK SHALES}

Samples of black Devonian oil shale collected in Kentucky were roasted and then assayed for $\mathrm{Ag}$ and $\mathrm{Au}$. Results, by counties, are (converted to $\mathrm{ppm}$ ): $\mathrm{Bath}, \mathrm{Ag}$ 7.1, Au 0.34; Boyle, Ag 0.51, Au tr; Bullitt, Ag 7.5, Au 0.34; Casey, Ag 2.9, Au 0.51; Clark, Ag 1, Au 0.34; Cumberland, Ag 1.7, Au 0.68; Elliott, Ag 3.9, Au 0.51; Estill, Ag tr, Au tr; Fleming, Ag 1.1, Au tr; Garrard, Ag 14, Au 0.34; Jefferson, Ag 0.68, Au 0.34; Lee, Ag 0.34, Au 0.0; Lewis, Ag 0.51, Au 0.51; Lincoln, Ag 1.4, $\mathrm{Au}$ tr; Madison, $\mathrm{Ag} \mathrm{2.7,} \mathrm{Au} \mathrm{0.34;} \mathrm{Marion,} \mathrm{Ag} \mathrm{0.85,} \mathrm{Au} \mathrm{0.17;} \mathrm{Montgomery,}$ $\mathrm{Ag} \mathrm{0.85}$, Au 0.51; Nelson, Ag 7.7, Au 0.17; Powell, Ag 1.36, Au 0.34; Rockcastle, $\mathrm{Ag} \mathrm{0.51,} \mathrm{Au} \mathrm{tr;} \mathrm{Rowan,} \mathrm{Ag} \mathrm{1.87,} \mathrm{Au} \mathrm{0.51;} \mathrm{and} \mathrm{Taylor,} \mathrm{Ag} \mathrm{5.6,} \mathrm{Au} \mathrm{0.51.} \mathrm{The} \mathrm{precious}$ metal content is well disseminated throughout the district.-EBT

Cucuel, Friedrich. See Stock, Alfred. 00298

Culkin, F. See Burton, J. D. 00070

00077 Curtis, C. D. Studies in the use of boron as a paleoenvironment indicator: Geochim. et Cosmochim. Acta, v. 28, p. 1125-1137, 1964.

Profiles of B analytical data for the Mansfield and Ryhope marine bands in the British Coal Measures of Late Carboniferous age at three localities in Yorkshire and Durham show marked similarities. Higher B contents are found in the marine band than above or below it. Faunal evidence, however, shows that the $\mathrm{B} /$ paleosalinity relationship is complex. Differing interpretations based on paleontologic evidence and $B$ data are not made more compatible by considering $\mathrm{B} / \mathrm{K}$ ratios. If the salinity relationship is ignored, $\mathrm{B}$ content, organic $\mathrm{C}$ content, and clay mineral content are intimately related. From a survey of published analytical data, a new mechanism of $B$ concentration is postulated, which rationalizes many conflicts about $B$ and paleosalinity. In the cores $B$ content ranged from 23 to $125 \mathrm{ppm}$; K, from 0.82 to 4.45 percent.-Author's abs., modified.

Danilchik, Walter. See Hyden, H. J.00184

00078 Davidson, C. F. The Kolm deposits of Sweden: Mining Mag. [London], v. 105, no. 4, p. 201-207, 1961.

The nodular, uranium-rich carbonaceous material known as kolm, found in the Upper Cambrian alum shales of Sweden, most probably originated as a hydrocarbon gel during the diagenesis of the shales, probably in latest Cambrian but possibly in Ordovician times. There is a strong presumption that the $U$ in kolm has accreted by epigenetic introduction from the shales and that losses of $\mathrm{Ra}$ and radiogenic $\mathrm{Pb}$ have occurred at more than one period. The range of $\mathrm{U}_{3} \mathrm{O}_{8}$ content in the kolm is from 0.14 to 0.64 percent with an average value of 0.45 percent. The average recorded value for the mid-Upper Cambrian horizons of the alum shale is 0.02 percent $\mathrm{U}_{3} \mathrm{O}_{8}$ with a comparatively high tenor of $\mathrm{V}, \mathrm{W}, \mathrm{Mo}, \mathrm{Ni}, \mathrm{Zn}, \mathrm{Cu}$, and other heavy metals.-EBT

00052 Davidson, D. F.; Gulbrandsen, R. A. Selenium in the Phosphoria Formation in Idaho, Wyoming, Utah, and Montana [abs.]: Geol. Soc. America Bull., v. 68, no. 12 , pt. 2 , p. 1714,1957 .

The Meade Peak Phosphatic Shale Member of the Permian Phosphoria Formation in Idaho, Wyoming, Utah, and Montana contains some of the most seleniferous sedimentary rocks known; the most seleniferous of these are in southeastern Idaho and western Wyoming. The highest concentrations of $\mathrm{Se}$ are in carbonaceous mudstone and phosphate rock. Se content in phosphate rock ranges from a few to $300 \mathrm{ppm}$ and in mudstone, from a few to more than $1,500 \mathrm{ppm}$. Se content shows a crude positive correlation with the contents of $\mathrm{S}$ and carbonaceous materials. No consistent correlation was found between Se and $\mathrm{P}_{2} \mathrm{O}_{5}$. The positive correlation between Se and V suggested by earlier workers is not consistent, but the highest content of Se occurs in the carbonaceous mudstone zone that contains a few tenths to more than 1 percent $\mathrm{V}_{2} \mathrm{O}_{5}$.- Authors' abs., condensed.

00079 Davidson, D. F.; Lakin, H. W. Metal content of some black shales of the western United States, in Short papers in the geologic and hydrologic sciences: U.S. Geol. Survey Prof. Paper 424-C, p. C329-C331, 1961. 
Semiquantitative spectrographic analyses of 6 carbonaceous marine shales of Paleozoic age from (1) Minnelusa Formation, S. Dak., (2) Phosphoria Formation, Wyo., (3) Deseret Limestone, Utah, (4) Chainman Shale, Nev., (5) unnamed, Fish Creek Range, Nev., and (6) Comus Formation, Nev., are presented. Contents found are (in ppm) in (1): $\mathrm{Pb} \mathrm{X0}, \mathrm{Mn}, \mathrm{X0}, \mathrm{Cu} 70-1,500, \mathrm{Zn}<500$, Ni 70-1,500, V 1,5003,000 , Mo 70-3,000, Ag 0-X00, Cr 150-300, Se 130-150; in (2): $\mathrm{Pb} 10-50$, $\mathrm{Mn}$ $100-300, \mathrm{Cu} 100-300$, Zn 700-10,000, Ni 150-1,500, V 500-7,000, Mo 50-500, Ag 2-30, Cr 500-5,000, Se 100-675; in (3): $\mathrm{Pb} \mathrm{0,} \mathrm{Mn} \mathrm{X0-X00,} \mathrm{Cu} \mathrm{X0,} \mathrm{Zn} \mathrm{X00-X,000,}$ $\mathrm{Ni} \mathrm{X0}-\mathrm{X} 00$, V X,000, Mo X-X0, Ag X0, Cr X00, Se 24-110; in (4): $\mathrm{Pb} \mathrm{30,} \mathrm{Mn}$ 300, Cu 200, Zn 2,000, Ni 100, V 1,000, Mo 50, Ag 20, Cr 1,000, Se 20; in (5): $\mathrm{Pb}<10-20$, Mn 20-500, Cu 15-100, Zn $<150-5,000$, Ni 10-100, V 200-2,000, Mo 5-50, Ag <1-2, Cr 50-150, Se 7-290; in (6): $\mathrm{Pb} 30, \mathrm{Mn} \mathrm{100-150,} \mathrm{Cu} \mathrm{200-500,}$ Zn 2,000-3,000, Ni $150-700$, V 3,000, Mo $<2-10$, Ag 5-30, Cr 200-300, Se $<1$ 1. $[\mathrm{X}-1$ to 9$]$.-EBT

00080 Davidson, D. F.; Lakin, H. W. Metalliferous shales in the United States [abs.]: Geol. Soc. America Spec. Paper 68, p. 18, 1962a.

As of December 1960 four shale units are known in the western United States whose metal contents are comparable to those of shale units considered ores in other parts of the world. These include the so-called "vanadiferous shale" in the Permian Phosphoria Formation in western Wyoming and southeastern Idaho, the Ordovician Comus Formation near Golconda, Nev., an unnamed lower Paleozoic formation in the Fish Creek Range near Eureka, Nev., and shale in the Mississsippian Deseret Limestone at Mercur Dome near Tintic, Utah. The shales are black and rich in orgar ic matter. Samples collected from these rocks contain as much as 1.5 percent $\mathrm{Zn}, 5$ percent $\mathrm{V}, 1-2$ percent $\mathrm{Ni}, 0.7$ percent $\mathrm{Se}$, and lesser amounts of other metals.Authors' abs., condensed.

00081 Davidson, D. F.; Lakin, H. W. Metal content of some black shales of the western conterminous United States, in Short papers in geology and hydrology: U.S. Geol. Survey Prof. Paper 450-C, p. C74, 1962 b.

Semiquantitative spectrographic analyses (Se determined by chemical analysis) of samples of carbonaceous marine shale from beds in 9 Paleozoic formations, Milligen Formation, Custer County, Idaho; Heath Formation, Fergus County, Mont.; Madison Limestone, Gallatin County, Mont.; Three Forks Shale, Gallatin County, Mont.; unnamed, Toquima Range, Nye County, Nev.; Chainman Shale, White Pine County, Nev.; unnamed, Taylor Canyon, Elko County, Nev.; unnamed, Goose Creek Valley, Elko County, Nev.; and Manning Canyon Shale, Utah County, Utah, are presented. The range in contents is (in ppm): $\mathrm{Pb} \mathrm{10-70,} \mathrm{Mn} \mathrm{100-500,} \mathrm{Cu}$ $70-700, \mathrm{Zn}<200-3,000$, Ni 50-200, V 1,000-3,000, Mo $<2-300, \mathrm{Ag}<1-15$, Cr 70 $500, \mathrm{Fe} 5,000-30,000, \mathrm{Se}--75$.- EBT

00051 Deans, T. The Kupferschiefer and the associated lead-zinc mineralization in the Permian of Silesia, Germany, and England: Internat. Geol. Cong., 18th, London, 1948, Rept., pt. 7, p. 340-352, 1950.

Modern literature on the Kupferschiefer is reviewed. This formation contains much more $\mathrm{Pb}$ and $\mathrm{Zn}$ than $\mathrm{Cu}$; $\mathrm{Cu}$ is restricted to small areas. The mineralization is zoned; copper sulfides occur at the base, maximum galena next, and sphalerite above. In central Germany this sequence is $1 \mathrm{~m}$ thick, but in the equivalent Kupfermergel and Bleimergel of Lower Silesia $\mathrm{Pb}$ and $\mathrm{Zn}$ zones persist into Middle Zechstein deposits. Galena characterizes the Kupferschiefer in northwest Germany and the Marl Slate in northeast England; sphalerite in the Lower Magnesian Limestone of Durham, and perhaps that in the Osnabrück Zechstein limestones, may represent the end phase of this mineralization. $\mathrm{Cu}, \mathrm{Pb}$, and $\mathrm{Zn}$ may have entered the Zechstein sea largely in meteoric ground waters; the traces of $\mathrm{V}, \mathrm{Ni}$, and Mo may be mainly biogenetic concentrations. In general, unmineralized Marl Slate contains (in ppm): V 950, Pb 400-700, Cu 90-120, Mo 310, Ni 230, Co 30, Zn <20-20, Cr 13. General content of trace elements in the Kupferschiefer, compiled from several sources, are (in ppm): V 400-2,000, Cu 100-30,000, Mo 150-300, Ni 40-400, Co 30-180, Cr 10-100.-Author's abs., modified. 


\section{BIBLIOGRAPHY OF MINOR ELEMENTS IN BLACK SHALES}

00082 Degenhardt, Heinz. Untersuchungen zur geochemischen Verteilung des Zirkoniums in der Lithosphäre [Investigation of the geochemical distribution of zirconium in the lithosphere (in German; English abs.)]: Geochim. et Cosmochim. Acta, v. 11, p. 279-309, 1957.

Minerals and rocks ( 287 samples) were analyzed for $\mathrm{Zr}$ by a colorimetric method. Analyses indicate that almost all rock-forming minerals contain small quantities of $\mathrm{Zr}$. The average $\mathrm{Zr}$ content of the lithosphere, calculated from analyzed igneous rocks according to their relative abundances, is $156 \mathrm{ppm}$. Generally sedimentary rocks contain about the same amount of $\mathrm{Zr}$ as igneous rocks. The $\mathrm{Zr}$ content in clays and shales (average, $160 \mathrm{ppm}$ ) is fairly constant, but in sandstones, especially quartzites, it varies greatly. The Devonian Wissenbacher Schiefer, Hartz, contains $134 \mathrm{ppm} \mathrm{Zr}$; the Devonian Dachschiefer, Rothaargebirge, 110; the Kulmtonschiefer, Silesia, 164; the Permian Kupferschiefer, Mansfeld and Werra, 137 and 170; Lias $\alpha$, Ziegelei Parensen, 110; and the Lias $\epsilon$, Mecklenburg, 120 ppm Zr.-Author's abs., modified.

00048 Degens, E. T.; Williams, E. G.; Keith, M. L. Application of geochemical criteria, pt. 2 of Environmental studies of Carboniferous sediments: Am. Assoc. Petroleum Geologists Bull., v. 42, no. 5, p. 981-997, 1958.

Investigation shows that the fresh-water or marine character of sedimentary rocks can be determined by geochemical criteria. An environmental diagram with B, Ga, and $\mathrm{Rb}$ abundances as variables shows some overlap of data from fresh-water and marine rocks, but a zone of overlap can be defined by straight lines so that 80 percent of a group of Pennsylvanian shales and limestones are classified in accord with the evidence of diagnostic fossils. In marine shales the averages are (in ppm): B 115, Ga 8, and Rb 281; in fresh-water shales they are: $\mathrm{B} \mathrm{44,} \mathrm{Ga} \mathrm{17,} \mathrm{and} \mathrm{Rb}$ 139. It is likely that trace element studies will be generally useful in stratigraphy and paleogeography by facilitating environmental determination of nonfossiliferous rocks.-Authors' abs., modified.

00083 Degens, E. T.; Williams, E. G.; Keith, M. L. Geochemical criteria for differentiating marine from fresh-water shales, $p t .1$ of Environmental studies of Carboniferous sediments: Am. Assoc. Petroleum Geologist Bull., v. 41, no. 11, p. 2427-2455, 1957; abs., Geol. Soc. America Bull., v. 68, p. 1715, 1957.

Trace-element assemblages and clay-mineral ratios are in some respects characteristic of the depositional environment of shales. $\mathrm{B}$ and $\mathrm{Rb}$ are more abundant in samples of marine shales than in samples of fresh-water shales (both of Pennsylvanian age), whereas $\mathrm{Ga}$ is more abundant in the fresh-water group. $\mathrm{Ag}, \mathrm{Co}, \mathrm{Cu}, \mathrm{Ni}, \mathrm{Pb}, \mathrm{Sn}, \mathrm{V}, \mathrm{Zn}$ and $\mathrm{Mo}$ are selectively enriched in the ash of organic matter in shales. $\mathrm{Ni}$ and $\mathrm{V}$ are concentrated in the organic fraction of marine shales; $\mathrm{Pb}, \mathrm{Zn}, \mathrm{Cu}$ and $\mathrm{Sn}$ are more highly concentrated in the organic fraction of freshwater shales. In the Appalachian coal basin it appears possible to differentiate marine shales from fresh-water shales by quantitative spectrographic determination of $\mathrm{B}, \mathrm{Ga}$, and Rb. Ranges of trace-element contents in the shales studied are (in ppm; range of contents in ash of the organic fraction given in parentheses): marine, Ag nd (2-8), B 50-150 (70), Ba 300-600 (250-400), Be 6-15 (10), Co nd-40 (20$40), \mathrm{Cr} 40-100(60-80)$, Cu 50-120 (100-800), Ga nd-40, Mn 250-4,000 (200-2,500), Mo nd-4 (nd-6), Ni 20-100 (70-150), Pb 15-50 (40-150), Rb 70-500 (100), Sn 2$5(5-10)$, Sr 300-600 (200-300), V 20-70 (150-200), Zn nd-250 (300-1,000); brackishwater, Ag nd (1-4), B 45-130 (60-80), Ba 400-700 (400-600), Be 7-20 (15), Co nd$10(10-30)$, Cr 40-100 (50-70), Cu 35-100 (200-900), Ga 2-45 (--), Mn 250-2,000 (200-350), Mo nd-3 (nd-3), Ni 10-40 (30-40), Pb nd-70 (30-50), Rb 60-450 (150$200)$, Sn nd-30 (20-80), Sr 300-800 (400), V 20-60 (60-80), Zn nd (1,500); freshwater, Ag nd (2-5), B 15-70 (15-30), Ba 250-1,000 (300-400), Be 9-20 (10-20), Co nd-10 (10-40), Cr 40-200 (60-100), Cu 40-100 (500-1,500), Ga 7-40 (15), Mn 2003,000 (200-700), Mo nd-3 (3-4), Ni 15-40 (20-25), Pb 10-80 (100-400), Rb 20$300(80-100)$, Sn $2-10(20-40)$, Sr 200-600 (200-300), V 30-80 (80-100), Zn nd (400 1,500).-Authors' abs., modified.

Degens, E. T. See Keith, M. L. 00194 
00050 Degens, Egon. Geochemische Untersuchungen zur Faziesbestimmung im Ruhrkarbon und im Saarkarbon. [Geochemical investigations toward determining facies of the Ruhr- and Saar-Carboniferous (in German)]: Glückauf, v. 94, no. $15 / 16$, p. 513-520, 1958.

Sedimentary rocks of Carboniferous age were analyzed in order to correlate composition with marine, brackish, or fresh-water origin as previously determined by fossil content. The samples (226) were analyzed for $\mathrm{Mn}, \mathrm{Fe}, \mathrm{CO}_{2}$, and $\mathrm{P}$, and 24 samples were analyzed for trace elements. The average trace elements contents in marine facies are (in ppm): $\mathrm{Ba} 860, \mathrm{Sr} 300, \mathrm{Ni} \mathrm{16,} \mathrm{Mo} \mathrm{13,} \mathrm{Cu} \mathrm{360,} \mathrm{Ga} \mathrm{10,}$ Ti 3,800, Cr 85, V 85, B 30; in nonmarine facies: Ba 610 , Sr 100, Ni 10, Mo $10, \mathrm{Cu} 120, \mathrm{Ga} 20, \mathrm{Ti} 7,300, \mathrm{Cr} 165, \mathrm{~V} 165, \mathrm{~B} 12$. The ratio, $\mathrm{Mn}: \mathrm{Fe}$, is characteristic of a facies and it averages 0.014 for nonmarine and 0.025 for marine facies. Ba, $\mathrm{Sr}, \mathrm{Cu}, \mathrm{Ni}, \mathrm{Mo}$, and $\mathrm{B}$ follow the $\mathrm{Mn}$ trend; $\mathrm{Cr}, \mathrm{Ga}, \mathrm{Ti}$, and $\mathrm{V}$ are distributed inversely to $\mathrm{Mn}$. Subsequent coalification processes may cause some redistribution of the elements.-EBT

00049 DeGrazia, A. R.; Haskin, Larry. On the gold contents of rocks: Geochim. et Cosmochim. Acta, v. 28, p. 559-564, 1964.

A neutron activation technique was used to examine 41 materials for their gold contents. The spread in gold concentrations was found to be relatively narrow, between 0.6 and $44 \mathrm{ppb}$, for the fairly wide variety of samples. A crustal gold abundance of about $2.5 \mathrm{ppb}$ is indicated. The Muncie Creek Shale Member of Wyandotte County, Kansas, contains $7.2 \mathrm{ppb}$ gold. [Note: The Muncie Creek is a 1-to 3-ft black shale member of the Iola Limestone of Missouri (Pennsylvanian) age.]-EBT

00084 Deul, Maurice. Concentration of minor elements in carbonaceous fractions mechanically segregated from some sedimentary rocks [abs.]: Geol. Soc. America Bull., v. 67, no. 12, pt. 2, p. 1686-1687, 1956.

Certain elements are concentrated in organic fractions in sedimentary rock; their enrichment factors in the organic matter are compared with the mineral matter. Semiquantitative spectrographic analyses were made on the ash of organic and mineral separates and on original rock; the results were converted from ash basis to original basis for comparisons. Except for $\mathrm{U}$, La, and Ce, none of the elements concentrated in the organic material is dominantly lithophile. $\mathrm{V}, \mathrm{Fe}, \mathrm{Co}, \mathrm{Ni}, \mathrm{Cu}$, $\mathrm{Zn}, \mathrm{Mo}, \mathrm{Ag}, \mathrm{Pb}$, and $\mathrm{Sn}$ characteristically form complex compounds which might be fixed with organic material. The mineral fractions show the expected concentrations of $\mathrm{Si}, \mathrm{Al}, \mathrm{Ca}, \mathrm{Mg}, \mathrm{Na}, \mathrm{K}, \mathrm{Ba}, \mathrm{Sr}, \mathrm{Ti}$, and $\mathrm{Zr}$. Elements not significantly concentrated in either fraction are $\mathrm{Be}, \mathrm{Sc}, \mathrm{Cr}, \mathrm{Ga}, \mathrm{Mn}, \mathrm{Y}$, and $\mathrm{Yb}$. Neither Bi (limit of detection $50 \mathrm{ppm}$ ) nor Ge (limit of detection $10 \mathrm{ppm}$ ) was found in any fraction.-Author's abs., condensed.

00040 Dunham, K. C. Syngenetic and diagenetic mineralization in Yorkshire: Yorkshire Geol. Soc. Proc., v. 32, pt. 3, p. 229-284, 1960.

The bedded iron ores, sulfide-bearing black shales and evaporites of Yorkshire are described. Abundant decaying vegetable or animal matter was necessary to produce the low Eh, low $\mathrm{pH}$, and available $\mathrm{CO}_{2}$ to form both the clay-ironstones of the Coal Measures and the sideritic chamosite-oolites of the Jurassic. The alum shales and the ironstones in the Coal Measures and the Jurassic rocks contain significant $\mathrm{Zn}, \mathrm{Pb}$, and $\mathrm{Cu}$. The Margaritatus zone of the Lias contains siderite nodules with cracks filled with pyrite, sphalerite, and barite, probably concentrated from the surrounding shale. The Permian Marl Slate (Kupferschiefer), a thin dolomitic carbonaceous siltstone near the base of the Permian, contains from 100 to 1,000 times the base-metal content of average geochemical background.-EBT

Dunham, K. C. See Hirst, D. M. 00085

00041 Dunham, Kingsley. Black shale, oil and sulfide ore: Adv. Sci., v. 18, no. 73, p. $284-299,1961$. 


\section{BIBLIOGRAPHY OF MINOR ELEMENTS IN BLACK SHALES}

Black mud presently forms in swamps, estuaries, lagoons, silled marine basins, and in hollows where stagnation prevails on the sea floor. Widespread precipitation of iron sulfide and some $U$ is occurring, but precipitation of other metal sulfides is not known. Evidence from the past suggests that although other metals may have been concentrated in ancient black muds, such metals as $\mathrm{Cu}, \mathrm{Zn}$ and $\mathrm{Pb}$ are concentrated only under very special local conditions like the introduction of hydrothermal fluids into a stagnant environment by submarine springs. New analyses of the Jet Rock Shale and the alum shale of Jurassic age from Yorkshire show minor-element contents, except $\mathrm{Pb}$, within the average range for ordinary shale. Stagnation under euxinic or similar conditions or rapid deposition in organically productive waters leads to the preservation of $C$ and other biophile elements mostly as stable kerogen in black shale; sapropelic muds will yield kerogen that produces hydrocarbons upon distillation. The role of anaerobic bacteria in precipitation of sulfides is important. Minor element contents in the alum shale, Jet Rock Shale and Marl Slate, as estimated from a logarithmic plot of the data, are (in ppm): alum shale, $\mathrm{Cu} 50, \mathrm{~Pb} \mathrm{70,} \mathrm{Sr} 200, \mathrm{Zn} 70$; Jet Rock Shale, Ba 200, Co 20, Cu 40, Ni 100, Pb 80, Sr 230, V 200, Zn 80; Marl Slate, Ba 2,000, Co 25, Cu 90-200, Ni 200, Pb 400-500, V 300, Zn 120-200.-EBT

00046 Eckschlagerová, Marcela. Příspěvek k geochemii vanadu v silurských břidlichích [Vanadium geochemistry in Silurian slates (in Czech; English and Russian summ.)]: Sbornik Vysoke Skoly, Chem.-Technol. v Praze, Oddil Fak. Anorg. a Org. Techn., p. 297-302, 1958.

The content of $\mathrm{V}$ in relation to the content of bitumen in Silurian slates, taken from Prague "Vyskočilka" was traced. The slates are enriched in V not only above its clarke value, but above the average $\mathrm{V}$ content in sedimentary rocks. The greatest $\mathrm{V}$ content is in the marginal parts of the slate band. $\mathrm{V}$ content is directly proportional to bitumen content. The amount of $\mathrm{V}$ in Tertiary slates of the Líten layers is estimated at $765 \mathrm{ppm}$.- Author's English abs., modified.

00047 Edgington, Glen; Byers, H. G. Selenium content and chemical analyses, pt. 9 of Geology and biology of North Atlantic deep-sea cores between Newfoundland and Ireland: U.S. Geol. Survey Prof. Paper 196-F, p. 15I-155, 1942.

The content of organic matter, determined in 123 samples, ranges from 0.1 to 1.0 percent of the total weight and averages about 0.5 percent. The organic matter content tends to be greater in the warm zones than in the cold zones and generally it is slightly greater in sediments deposited where the surface water was relatively warm. The organic content is related to texture and increases with increasing fineness of the sediments. The core from the continental shelf off Ocean City, Md., contained the most $\mathrm{Se}-$ at the top $0.6 \mathrm{ppm}$; at $1 \mathrm{~m}, 1 \mathrm{ppm}$; and at $2 \mathrm{~m}, 2 \mathrm{ppm}$. In samples from the North Atlantic cores Se content ranged from 0.06 to $0.8 \mathrm{ppm}$. One sample from the Bartlett Deep contained $0.2 \mathrm{ppm} \mathrm{Se}$; all others contained less than $0.008 \mathrm{ppm}$.-EBT

Egamberdyev, M. V. See Amirkhanov, Sh. Kh. 00022

Ehmann, W. D. See Baedecker, P. A. 00007

00042 Eisentraut, Otto. Der niederschlesische Zechstein und seine Kupferlagerstätte [The Lower Silesian Zechstein and some copper ore deposits (in German)]: Arkiv Lagerstättenf., no. 71, 116 p., 1939.

The stratigraphy, correlations between depositional basins and between adjoining regions, paleontology, paleogeography, structure, and geochemistry of the Zechstein rocks in Silesia are discussed with special attention directed toward the Kupfermergel. Analyses of the Kupfermergel are compared with those of the Kupferschiefer at Mansfeld. The marly facies of the Kupfermergel in the Haaseler Basin showed the following range in composition (in percent): $\mathrm{CaO} 6-43, \mathrm{MgO}$ 1.8-3.6, $\mathrm{Al}_{2} \mathrm{O}_{3} 8-20, \mathrm{SiO}_{2} 9-52, \mathrm{Na}_{2} \mathrm{O}+\mathrm{K}_{2} \mathrm{O}$ 2.7-7.4, organic $\mathrm{C} 0.5-1, \mathrm{CO}_{2}$ from carbonate 5-18, $\mathrm{Cu} 0.6-2.1, \mathrm{Fe} \mathrm{0.9-3.3,} \mathrm{S} \mathrm{0.2-2,} \mathrm{Ag} \mathrm{21-57} \mathrm{ppm.} \mathrm{In} \mathrm{the} \mathrm{Gröditzer}$ Basin the mean values in the Kupfermergel were (in percent): $\mathrm{CaO} 22, \mathrm{MgO} 3.8$, $\mathrm{Al}_{2} \mathrm{O}_{3} 11, \mathrm{SiO}_{2} 29, \mathrm{Na}_{2} \mathrm{O}+\mathrm{K}_{2} \mathrm{O}$ 5.3, organic $\mathrm{C} \mathrm{1,} \mathrm{Cu} \mathrm{1.2,} \mathrm{Fe} \mathrm{2.4,} \mathrm{S} \mathrm{1,} \mathrm{and} \mathrm{Ag}$ 43 ppm.-EBT 
00043 Ekiert, Franciszek. Warunki geologiczne i objawy mineralizacji Cechsztynu w niecce Manfeldskie (Sprawozdanie z pobytu w NRD) [Geological conditions and the mineralogical character of the Zechstein in the Mansfeld basin (report from a stay in the German Democratic Republic) (in Polish; English and Russian summ.)]: Warsaw Inst. Geologiczny Biul. 126, p. 57-110, 1958.

The copper-bearing shale deposits contain the following syngenetic minerals: native silver, chalcocite, bornite, chalcopyrite, pyrite, argentite, galena, sphalerite, stromeyerite, and tetrahedrite. So far, 51 elements have been found in the shale. Of these, $\mathrm{V}, \mathrm{Ni}, \mathrm{Zn}, \mathrm{Mo}, \mathrm{Ag}, \mathrm{Cd}, \mathrm{Se}, \mathrm{Re}, \mathrm{Pb}$, and $\mathrm{Au}$ are present in commerically important amounts. The Mansfeld deposits are related to those in the Harz Mountains. During Lower Zechstein sedimentation, hydrothermal solutions carrying heavy-metal compounds reached the surface through fissures, both in the Harz and on its margin. Part of these solutions was transported directly into the Zechstein sea; another part mixed with meteoric water on land and was carried to the sea. Sulfides were precipitated from the sea water simultaneously with the deposition of the Mansfeld shales in the highly reducing environment caused by the lagoonal nature of the Zechstein sea.-EBT

Emel'yanov, E. M. See Kochenov, A. V. 00405

00044 Engelhardt, Wolf. Die Geochemie des Barium [The geochemistry of barium (in German)]: Chemie der Erde,v. 10, p. 187-246, 1936.

Two quantitative spectroanalytical methods to determine $\mathrm{Ba}$ in rocks are described. Using these methods, 225 individual rocks and minerals, composite samples of rocks and minerals, meteorites, and samples from the biosphere were analyzed for $\mathrm{Ba}$. The average $\mathrm{Ba}$ content in shales is $500 \mathrm{ppm}$; in the composite sample of 36 European Paleozoic shales, $550 \mathrm{ppm}$; in the composite sample of 14 Japanese Paleozoic shales, $580 \mathrm{ppm}$; in 10 Japanese Mesozoic shales, $300 \mathrm{ppm}$; in 9 southern Scandinavian Dictyograptus shales, 1,200 ppm; and in the Mansfeld Kupferschiefer, $75 \mathrm{ppm}$. During the formation of sedimentary rocks, Ba, carried by rivers to the sea, is almost entirely removed from the water by sorption on clay layers, forming barium-rich shales on the shelf areas of the continents.-EBT

00403 Engels, Bruno. Uber die Fazies des Hunsrückschiefers [Facies of the Hunsruck Shale (in German)]: Geol. Rundschau, v. 45, no. 1, p. 143-150, 1956.

A study of the Hunsruck Shales of Early Devonian age shows that they were deposited in shallow seas. Spectroscopic-chemical analyses of 7 samples show the following possible average contents (in percent): $\mathrm{Si} 10-100, \mathrm{Al} \mathrm{3-30,} \mathrm{Na} \mathrm{3-30,} \mathrm{Fe}$ 1-10, Mg 1-10, K 0.3-3, Ca 0.1-1, Ti $0.03-0.3, \mathrm{Mn} 0.01-0.1, \mathrm{~Pb} 0.001-0.01$, V $0.0003-0.003$, $\mathrm{Ni} 0.0003-0.003$, and $\mathrm{Cu} 0.00003-0.0003$. One sample deviated from these spectrographic ranges, showing $\mathrm{Ca} 0.3-3$, Ti $0.1-1, \mathrm{~Pb} 0.01-0.1$, and $\mathrm{Cu} 0.0001-$ 0.001 percent.-EBT

Erd, R. C. See Murata, K. J. 00153

00045 Erdman, J. G.; Ramsey, V. G. Rates of oxidation of petroleum asphaltenes and other bitumens by alkaline permanganate: Geochim. et Cosmochim. Acta, v. 25, p. $175-188,1961$.

A variety of organic materials including coal, oil shale, bitumens, and organic matter separated by $\mathrm{HCl}$ and $\mathrm{HF}$ from carbonaceous rocks were subjected to oxidation by alkaline permanganate for comparison. Elemental and ash analyses of selected samples show the following (in percent): nonmarine organic matter from clay of Pennsylvanian age below the Pittsburg coal seam, S 1.18, C 33.4, H 3.1, O 8.0, $\mathrm{N} \mathrm{1.00,} \mathrm{ash} \mathrm{48.82,} \mathrm{Fe} \mathrm{1.35,} \mathrm{V} \mathrm{--,} \mathrm{Ni} \mathrm{--;} \mathrm{oil} \mathrm{shale,} \mathrm{Green} \mathrm{River} \mathrm{Formation} \mathrm{of} \mathrm{Eocene}$ age, $\mathrm{S} 3.15, \mathrm{C} 65.7, \mathrm{H} 9.1, \mathrm{O} 8.9$, N 2.13, ash 8.63, Fe 1.57, V 0.006, Ni 0.009; La Luna Limestone, marine of Early Cretaceous age, Venezuela, S 6.87, C 78.0, H 6.1, O 7.6, N 1.13, ash 5.34, Fe 0.63, V 0.53, Ni 0.084-Authors' abs., modified.

Erickson, R. L. See Gott, G. B. 00111 
00044 Ericson, D. B.; Ewing, Maurice; Wollin, Goesta; Heezen, B. C. Atlantic deepsea sediment cores: Geol. Soc. America Bull., v. 72, no. 2, p. 193-286, 1961.

Lithologic, grain-size distribution, micropaleontologic and chemical analyses of 221 Atlantic and Caribbean deep-sea cores lead to new conceptions of processes of sedimentation, rates of accumulation, Pleistocene chronology, and pre-Pleistocene history of the Atlantic basin. Pre-Pleistocene sediments were found in 41 cores; the oldest was Late Cretaceous. The fairly common occurrence of plant debris in graded layers proves that organic matter can be transported by turbidity currents. Hydrotroilite, commonly present in the clayey parts of the graded layers, is indirect evidence of finely divided organic matter. Spectrochemical analyses of top samples of deep-sea cores have the following range in minor-element composition (in ppm): $\mathrm{SrO}<50-1,800, \mathrm{MnO} 160->1,800, \mathrm{CuO}<30-170, \mathrm{~V}_{2} \mathrm{O}_{5}<50-300, \mathrm{BaO}<40-560$, $\mathrm{Cr}_{2} \mathrm{O}_{3}<100-1,800, \mathrm{~B}_{2} \mathrm{O}_{3} 200-1,100$, and $\mathrm{PbO}<50-240 .-\mathrm{EBT}$

Erlenmeyer, H. See Blumer, Max. 00017

00128 Ernst, Werner. Diagnose der Salinitätsfazies mit Hilfe des Bors [Diagnosis of saline facies with the aid of boron (in German; English abs.)]: Fortschr. Geologie Rheinland u. Westfalen, v. 10, p. 239-252, 1963.

The B contents of the Upper Carboniferous strata depend principally on the original salinity of the area of sedimentation. The quartz content of the argillaceous sediments and the quantities of micaceous minerals have only a subordinate influence. In contrast to this, the climate appears to have an effect that manifests itself by increase in the $B$ contents from the Westphalian Carboniferous on. In the Upper Carboniferous rocks studied, $>350 \mathrm{ppm} \mathrm{B}$ indicated marine facies, 250 $350 \mathrm{ppm} B$ indicated brackish facies, and $<250 \mathrm{ppm}$ indicated fresh-water facies.Author's abs., modified.

00129 Ernst, Werner; Krejci-Graf, K.; Werner, H. Parallelisierung von Leithorizonten im Ruhrkarbon mit Hilfe des Bor-Gehaltes [Correlation of index horizons in the Ruhr Carboniferous by means of the boron content (in German; English abs.)]: Geochim. et Cosmochim. Acta, v. 14, p. 211-222, 1958.

Pelitic sediments of Carboniferous age in the Ruhr district have varying amounts of $B$ related to the degree of salinity of the water in which the sediments were deposited. $\mathrm{B}_{2} \mathrm{O}_{3}$ contents in fresh-water sediments range from 50 to $150 \mathrm{ppm}$; in typical marine sediments they range from 300 to $600 \mathrm{ppm}$. These contents seem to be stable during diagenesis and weathering; with incipient metamorphism they seem to decrease.-Authors' abs., modified.

00131 Ernst, Werner. Bestimmung der Salinitätsfazies tertiärer Tone der Niederrheinischen Bucht mit Hilfe des Bor-Gehaltes [Determination of the salinity facies of Tertiary clays of the lower Rhine Embayment by means of the boron content (in German)], in Ahrens, Wilhelm, ed., Die Niederrheinischen Braunkohlenformation: Fortschr. Geologie Rheinland u. Westfalen, v. 1, p. 9394, 1958.

The B content in clays of Tertiary age in the lower Rhine Embayment was studied. The average content in 7 marine marly clays of middle Oligocene age was 420 ppm $\mathrm{B}_{2} \mathrm{O}_{3}$ and the average content in 9 Miocene terrestrial clays in the Brown Coal formation was $240 \mathrm{ppm} \mathrm{B}_{2} \mathrm{O}_{3}$.- EBT

00130 Evans, W. D. The organic solubilization of minerals in sediments, in Colombo, Umberto, and Hobson, G. D., eds., Advances in organic geochemistry: Internat. Ser. Mon. Earth Sci., v. 15, p. 263-270, 1964.

Organic solubilization of minerals bears little relation to their inorganic solubility. The relatively insoluble sulfides of $\mathrm{Mn}, \mathrm{Co}, \mathrm{Ni}, \mathrm{Fe}, \mathrm{Cu}$, and most other metals are profoundly influenced by alanine and all $\alpha$-amino acids tested, as well as adenosine triphosphate. Oxides and hydroxides of $\mathrm{Fe}$ and $\mathrm{Al}$ are practically insoluble in organic solubilizers and are formed as precipitates from solutions during decomposition of $\mathrm{Na}-\mathrm{ATP}$. These reactions suggest an explanation for the origin of seat earths associated with coal seams in England.-JDV 
Ewing, Maurice. See Ericson, D. B. 00044

00132 Fahey, J. J. Saline minerals of the Green River Formation: U.S. Geol. Survey Prof. Paper 405, 50 p., 1962.

The drill core from the John Hay, Jr., well 1, in Sweetwater County, Wyo., was studied by the U.S. Geological Survey. The well penetrated the Wilkins Peak Member of the Green River Formation of early and middle Eocene age. Fourteen samples of oil shale from the drill core ranging in depth from 1,275 to $1,700 \mathrm{ft}$ that contained a minimum amount of saline minerals were analyzed. Chemical analysis showed the following range in composition (in percent): $\mathrm{SiO}_{2}$ 15.42-35.03, $\mathrm{Al}_{2} \mathrm{O}_{3}$ 1.98-8.64, $\mathrm{Fe}_{2} \mathrm{O}_{3}$ 0.50-2.48, $\mathrm{FeO} 0.65-1.25, \mathrm{TiO}_{2}$ 0.10-0.31, $\mathrm{P}_{2} \mathrm{O}_{5}$ 0.00-0.22, $\mathrm{CaO}$ 9.35-21.37, $\mathrm{MgO} 4.74-16.69, \mathrm{BaO} 0.00-0.02, \mathrm{MnO} 0.02-0.11, \mathrm{Na}_{2} \mathrm{O}$ 1.04-12:15, $\mathrm{K}_{2} \mathrm{O}$ 1.94-4.93, $\mathrm{Li}_{2} \mathrm{O} \quad 0.02-0.09, \mathrm{SO}_{3} 0.00, \mathrm{~S} \quad 0.08-2.17, \mathrm{Cl} \quad 0.04-2.38, \mathrm{CO}_{2}$ 14.4433.10, and organic matter 1.07-21.11. Quantitative spectrographic analysis showed the following range in minor element composition (in ppm): $\mathrm{Cu} 72-2,400$, Mo nd$220, \mathrm{~Pb}$ nd-40, Mn 200-900, Co nd-60, Ni 20-80, Cr 30-50, V 50-100, Sc nd2 , Y nd-20, Ti 90-2,000, Zr 10-70, Sr 800-5,000, Ba 60-2,000, Li 100-400, B 20200.-EBT

00126 Falke, Horst. Die bituminösen Schiefer des Beckens von Autun (Zentralfrankreich) [The bituminous shales of the Autun basin (central France) (in German)]: Eclogae Geol. Helvetiae, v. 51, no. 3, p. 623-634, 1959.

Chemical analyses of clay rock and bituminous material from the bituminous shales of Early Permian age are presented. $\mathrm{V}_{2} \mathrm{O}_{5}$ contents reported from the bituminous shale are 170 and $190 \mathrm{ppm} ; \mathrm{Cr}_{2} \mathrm{O}_{3}$ contents reported are 120 and $90 \mathrm{ppm}$.-EBT

Feely, H. W. See Turekian, K. K. 00350

Fesser, Hermann. See Seibold, Eugen. 00304

00127 Fischer, R. P. Geochemistry and geology, Chap. 3 in Busch, P. M., Vanadium, a materials survey: U.S. Bur. Mines Inf. Circ. 8060, p. 26-32, 1961.

Clays and shales contain about $120 \mathrm{ppm} \mathrm{V}$, sandstones about 20 , and carbonate rocks less than 10. As a rule, $V$ content increases with an increase in argillaceous material and especially with an increase in organic matter; $V$ is rather highly concentrated in some coal, petroleum, and asphalt. Shale beds about 35 to $50 \mathrm{ft}$ below the top of the Meade Peak Phosphatic Shale Member of the Permian Phosphoria Formation in southeastern Idaho and western Wyoming contain as much as 1.5 to 2.5 percent $\mathrm{V}_{2} \mathrm{O}_{5}$, and the entire zone averages 0.85 percent. The beds also contain 0.02 to 0.1 percent $\mathrm{Mo}, 0.02$ to 0.3 percent $\mathrm{Ni}$, and as much as 0.1 percent Se. Similar vanadiferous shales are present at the base of the Mississippian Deseret Limestone in the southwestern part of the Oquirrh Mountains,Utah.-EBT

00133 Fix, C. E. Selected annotated bibliography of the geology and occurrence of uranium-bearing marine black shales in the United States: U.S. Geol. Survey Bull. 1059-F, p. 263-325, 1958.

This bibliography consists of 81 annotated references to reports available to the public before June 30,1956, concerned with the geology and occurrence of $U$ in marine black shales. The annotations, arranged alphabetically by author, present information on geology, geographic distribution, environment of deposition, mode of occurrence, and analytical data. A map shows the distribution and $U$ content of uraniferous shales in the United States including Alaska. The data in the annotations are indexed according to author, geographic area, stratigraphic units, and subject.--Author's abs., modified.

Flegontova, E. I. See Katchenkov, S. M.00192

Flegontova, E. I. See Katchenkov, S. M.00215

00124 Fleischer, Michael. Some aspects of the geochemistry of yttrium and the lanthanides: Geochim. et Cosmochim. Acta, v. 29, no. 7, p. 755-772, 1965. 


\section{BIBLIOGRAPHY OF MINOR ELEMENTS IN BLACK SHALES}

The relative abundances of the lanthanides in limestones and shales are essentially identical even though shales contain about 4 times as much in absolute amounts. Shales contain $116 \mathrm{ppm}$ lanthanides ( $\mathrm{La}-\mathrm{Lu}$ ) and $23 \mathrm{ppm} \mathrm{Y}$; limestones, $28 \mathrm{ppm}$ lanthanides and $5.6 \mathrm{ppm} \mathrm{Y}$. Nothing is known of the form in which the lanthanides are present in limestones and shales; they might be present as adsorbed material on clays.-EBT

\section{Fleischer, Michael. See Wright, T. L. 00316}

00122 Flek, Jindrich. Vitriolové bridlice Hromnické [The vitriol shales of Hromnice (in Czech; English summ.)]: Czechoslovakia Státního Geol. Ustavu Vestník, v. 25 , no. 1 , p. $49-56,1950$.

The large deposit of vitriol shales at Hromnice was the supply of raw material for manufacture of fuming sulfuric acid through almost all the 19th century. These marine shales of Algonkian [Precambrian] age are almost black, laminated, locally weakly lustrous, and impregnated with pyrite. Chemical analysis of the shale shows about 3 percent $\mathrm{C}, 1.10$ percent $\mathrm{SO}_{3}, 6.12$ percent $\mathrm{FeS}_{2}$, and 17.34 percent $\mathrm{Al}_{2} \mathrm{O}_{3}$. A very pure pyrite concentrate representing 5.4 percent of the original rock was obtained by sluicing. Spectrographic analysis of this concentrate shows the following trace element content (in ppm): Mo 100, $\mathrm{W}<10$, Co 1,700, Ni 1,300, $\mathrm{Ag} 25, \mathrm{Au}$ $<5, \mathrm{Zn} \mathrm{700,} \mathrm{Cd}<10, \mathrm{Hg}<10, \mathrm{Ga} 100$, In 50, $\mathrm{Tl}<50, \mathrm{Ge}<50$, Sn nd, Pb 3,000, As $500, \mathrm{Sb}<100$, and $\mathrm{Bi}$ nd.-EBT

00123 Fleming, G. A.; Walsh, T. Selenium occurrence in certain Irish soils and its toxic effects on animals: Royal Irish Acad. Proc., v. 58, sec. B, no. 7, p. 151$166,1957$.

Rock samples were collected from outcrops of Upper and Middle Carboniferous limestones and associated shale and sandstone beds of the Yoredale and Pendleside series. Se contents in shale samples from counties affected by chronic Se poisoning of livestock were (in ppm): pyritiferous shale, Limerick County, 8.9, 29.5; shale bed, Limerick County, 0.85, 5.8; shale bed in limestone, Limerick County, 2.0; shale bed, Tipperary County, 0.1, 0.1, 0.25; weathered shale, Meath County, 13.0. Se contents in shale samples from some unaffected counties were (in ppm): Upper Avonian shale, Leitrim County, 6.1; shale coal measure, Clare County, 6.1; Upper Avonian shale, Dublin County, 1.3; Upper Avonian shale, Mayo County, 1.7.-EBT

Fleming, G. A. See Walsh, T. 00343

00134 Fröhlich, F. Beitrag zur Geochemie des Chroms [Contribution to the geochemistry of chronium (in German; English abs.)]: Geochim. et Cosmochim. Acta, v. 20, p. 215-240, 1960.

$\mathrm{Cr}$ has been determined in 227 rocks and minerals by means of the diphenylcarbazide colorimetric method, which was modified for this purpose. The mean error of the method, expressed as the difference between duplicate determinations, is \pm 2 percent, and the limit of detection is $1 \mathrm{ppm}$. Pelitic sediments show a very uniform $\mathrm{Cr}$ content. Of 40 samples investigated, 24 contained $70-110 \mathrm{ppm} \mathrm{Cr}$; the contents of the other samples were near these values. The $\mathrm{Cr}$ in sediments is mostly concentrated in the micas and clay minerals, particularly in illite. The $\mathrm{Cr}$ content of the deep-sea clays ranged from 60 to $109 \mathrm{ppm}$. The composite of 36 European Paleozoic shales contained $133 \mathrm{ppm} \mathrm{Cr}$. Cr content in the Keuper Shale [Triassic] was $83 \mathrm{ppm}$; in the Lias Shale, $126 \mathrm{ppm}$; and in the Kupferschiefer, 100-353 ppm.EBT

Fuller, G. W. See Tschanz, C. M. 00281

00125 Gamaleyev, I. E.; Khamrabayev, I. Kh. Vanadiy i molibden v siluriyskikh otlozheniyakh gor Mal'guzar, Nuratau, i Tamdy [Vanadium and molybdenum in Silurian deposits of the Mal'guzar, Nuratau, and Tamdy Mountains (in Russian, Uzbekian abs.)]: Akad. Nauk Uzbek. SSR, Uzbek. Geol. Zhur., no. 2, p. 47-54, 1958. 
The Venlok-Landoverian deposits of Silurian age are characterized by increased contents of Mo, V, and some other elements. Some of this concentration is due to metasomatism, but in unmetamorphosed carbonaceous clayey shale the mean contents of $\mathrm{V}$ are $800-1,000 \mathrm{ppm}$ and of $\mathrm{Mo} 20-30 \mathrm{ppm}$. The primary accumulation of $\mathrm{V}$ and $\mathrm{Mo}$ is bound with the organic material.-EBT

Gehl, M. A. See Haskin, Larry. 00102

Geydarov, A. S. See Zul'fugarly, N. D. 00319

Ghaly, E. L. See Mustafa, Ahmed. 00272

00120 Gil-av, E.; Heller, S.; Steckel, F. The Um Barek oil shale: Israel Research Council Bull., v. 4, no. 2, p. 136-143, 1954.

Widespread Israelian oil shale is Senonian [Late Cretaceous] in age and contains 10-12 percent organic material and has an oil yield of about 5 percent. It is about 50-60 percent limestone or dolomite and contains $20-30 \mathrm{ppm}$ U. Spectrographic analysis also showed the presence of $\mathrm{Cr}, \mathrm{Sr}, \mathrm{Co}, \mathrm{Zr}, \mathrm{Cu}, \mathrm{V}, \mathrm{Mo}, \mathrm{Ni}, \mathrm{Ti}, \mathrm{Ba} ; \mathrm{Ga}$, $\mathrm{Na}, \mathrm{Li}$, and $\mathrm{K}$.- EBT

Gilbert, C. S. See Beath, O. A. 00013

Gill, J. R. See Tourtelot, H. A. 00279

00121 Glagoleva, M. A. Zakonomernosti raspredeleniya elementov v sovremennykh osadkakh Chernogo morya [Regularities in the distribution of chemical elements in modern sediments of the Black Sea]: Akad. Nauk SSSR, Doklady, v. 136, no. 1, p. 195-198, 1961a; English translation: New York, Consultants Bur., Inc., 1962.

Chemical analyses of 180 samples of bottom sediments of the Black Sea show that $\mathrm{V}, \mathrm{Cr}, \mathrm{Fe}, \mathrm{Mn}, \mathrm{Ni}$, and $\mathrm{Cu}$ contents increase from sand to clay and then decrease in lime mud. $\mathrm{P}$, organic $\mathrm{C}, \mathrm{Co}, \mathrm{Ca}$, and $\mathrm{Sr}$ increase continuously from sand to clay to lime mud. Maximum contents of $\mathrm{V}, \mathrm{Cr}, \mathrm{Fe}, \mathrm{Ni}$, and $\mathrm{Mn}$ occur in coastal silt and clay. Maximum $\mathrm{Cu}, \mathrm{Co}$, organic $\mathrm{C}, \mathrm{P}, \mathrm{Ca}$, and $\mathrm{Sr}$ occur in finer sediment farther from shore. The range in composition is (in ppm): $\mathrm{Fe} 11,800-36,800, \mathrm{Mn}$ $320-660$, P $310-590$, Sr 50-650, V $13-99$, Cr $25-84$, Ni 19-67, Cu 20-80, Co 816, (in percent): organic $\mathrm{C} 0.24-3.7$, and $\mathrm{CaCO}_{3}$ 12.3-60.-EBT

00135 Glagoleva, M. A. K voprosii o vliyanii solenosti basseyna na nakopleniye elementov $v$ ego osadkakh [The problem of the effect of basin salinity on the accumulation of elements in its deposits]: Akad. Nauk SSSR Doklady, v. 136, no. 2, p. 441-443, 1961 b; English translation: New York, Consultants Bur., Inc., p. $8-10[1962]$.

Samples from 3 cores, as much as $10 \mathrm{~m}$ long, through Recent, Old Black Sea, and Novoevksin deposits show salinity of depositional environment gradually increased from 0.4 percent in water of the Novoevksin (New Euxine) basin to 0.8 in the Old Black Sea basin to 1.8 in the Recent Black Sea. Generally, organic C and minor element contents vary the most in vertical distribution. No relationship was observed between element and C contents or petrography. Appreciable increase in salinity did not cause noticeable changes in accumulation of elements studied. Ranges of contents in the deposits are $\left(\mathrm{CaCO}_{3}\right.$, organic $\mathrm{C}$ and $\mathrm{Fe}$ in percent; rest in ppm): Recent, $\mathrm{CaCO}_{3} 20.8-26.8$, C 1.76-2.23, Fe 1.78-3.91, Mn 300-700, P 400-600, Co 14-28, V 90-146, Cr 8-365, Cu 13-45, Ni 24-58; Old Black Sea, $\mathrm{CaCO}_{3}$ 10.5-28.6, C 1.45-28.6, Fe 3.40-4.33, Mn 400-600, P 600, Co 3-23, V 123-168, Cr tr-80, Cu 22-28, Ni 45-60; Novoevksin, $\mathrm{CaCO}_{3}$ 6.7-31.2, C 0.43-2.01, Fe 3.57-4.98, Mn 8001,600, P 600-800, Co 7-30, V 112-157, Cr 49-113, Cu 17-50, Ni 31-68.-EBT

00136 Glogoczowski, J. J. Wstepna charakterystyka petrograficzna ilów miocenu Przedgórza Karpat [Preliminary petrographic characteristic of Miocene clays from the Carpathian Foreland (in Polish; English summ.)]: Rocznik Polsk. Towarzystwa Geol., v. 33, no. 1/3, p. 111-118, 1963. 


\section{BIBLIOGRAPHY OF MINOR ELEMENTS IN BLACK SHALES}

The clayey marine Miocene deposits in the Carpathian foredeep are as much as $1,700 \mathrm{~m}$ thick. Data from analyses of samples of numerous drill cores are summarized, including DTA logs, $\mathrm{Ca}, \mathrm{Mg}, \mathrm{Cl}$, and bitumen content, and some spectrochemical data. The principal component of the shales is illite; a variable amount of montmorillonite occurs. Accessory minerals are quartz, calcite, gypsum, anhydrite, halite, and pyrite. Ca content is generally $2-7$ percent, $\mathrm{Mg} 0.5-2$ percent, mean $\mathrm{Cl} 0.1$ percent, and the mean bitumen content 0.025 percent; the maximum bitumen is 0.24 percent. The assemblage of trace elements is similar throughout the Miocene profile. $\mathrm{Ba}, \mathrm{Sr}, \mathrm{Mn}, \mathrm{V}, \mathrm{Cr}, \mathrm{Ni}, \mathrm{Ti}, \mathrm{Co}, \mathrm{Mg}, \mathrm{Cu}$ were found. $\mathrm{V}$ content ranged from 30 to $310 \mathrm{ppm}$; $\mathrm{Ni}$, from 10 to $90 \mathrm{ppm}$; and $\mathrm{Cr}$, from 40 to $370 \mathrm{ppm}$.Author's summ., condensed.

00113 Glover, Lynn. Stratigraphy and uranium content of the Chattanooga Shale in northeastern Alabama, northwestern Georgia, and eastern Tennessee: U.S. Geol. Survey Bull. 1087-E, p. 133-168, 1959.

In northeastern Alabama, northwestern Georgia, and eastern Tennessee, the Chattanooga Shale of Late Devonian age ranges in thickness from 0 to more than $40 \mathrm{ft}$. Less stable conditions of development and wide distribution of phosphatic black shale account for the generally low $U$ content (less than $50 \mathrm{ppm}$ ) of the Chattanooga Shale in the region studied.-Author's abs., condensed.

00114 Goldberg, E. D.; Arrhenius, G. O. S. Chemistry of Pacific pelagic sediments: Geochim. et Cosmochim. Acta, v. 13, p. 153-212, 1958.

The chemical and mineralogical composition of pelagic sediments from the eastern Pacific Ocean was studied to try to define the ultimate sources and the mechanisms of formation of the solid phases. The contribution of elements from the different geospheres is considered. Emission spectrographic analyses of a wide variety of pelagic clays allow a reformulation of the geochemical balance. Pelagic clays account for approximately 13 percent of the total mass of sediments produced during geologic time. The average chemical composition (in weight percent) of pelagic sediments is: $\mathrm{Si} 23.0, \mathrm{Al} 9.2, \mathrm{Fe} 6.5, \mathrm{Ti} 0.73, \mathrm{Mg} 2.1, \mathrm{Ca} 2.9, \mathrm{Na} 4.0, \mathrm{~K} 2.5, \mathrm{Sr} 0.071, \mathrm{Ba}$ 0.39 , B $0.030, \mathrm{Mn} 1.25$, Ga 0.0019 , Ni $0.032, \mathrm{Cu} \mathrm{0.074,} \mathrm{Co} \mathrm{0.016,} \mathrm{Cr} 0.0093$, V 0.045 , Pb 0.015, Mo 0.0045, Zr 0.018, Yb 0.0021, Y 0.015, La 0.014, and Sc 0.0025.Authors' abs., modified.

00086 Goldschmidt, V. M.; Krejci-Graf, K.; Witte, H. Spuren-Metalle in Sedimenten [Trace metals in sediments (in German)]: Akad. Wiss. [Göttingen], math.-phys.chem. Abt., Nachr., no. 2, p. 35-52, 1948.

The results of spectrographic analyses for $\mathrm{Ni}, \mathrm{Co}, \mathrm{Cr}, \mathrm{V}, \mathrm{Mo}$, and $\mathrm{Sn}$ in bituminous and nonbituminous rocks from the Rumanian oil fields and in bituminous rocks from throughout the world are reported and compared. The ranges of element contents in organic-rich shale, clay, and mud are (in ppm): marine gyttja-rock and mud: $\mathrm{NiO} 10-500, \mathrm{Co}_{3} \mathrm{O}_{4} 10-100, \mathrm{Cr}_{2} \mathrm{O}_{3}<10-500, \mathrm{~V}_{2} \mathrm{O}_{3} 50-500, \mathrm{MoO}_{3} \ldots$ ,- and $\mathrm{SnO}_{3} \ldots-$; $_{1}$ in brackish gyttja-clay and mud: $\mathrm{NiO} 10-100, \mathrm{Co}_{3} \mathrm{O}_{4} 10-100$, $\mathrm{Cr}_{2} \mathrm{O}_{3} 50-500, \mathrm{~V}_{2} \mathrm{O}_{3}$ 100-500, $\mathrm{MoO}_{3}---$, and $\mathrm{SnO}_{3}---$ in marine sapropel: $\mathrm{NiO}$ $10-500, \mathrm{Co}_{3} \mathrm{O}_{4} 10-100, \mathrm{Cr}_{2} \mathrm{O}_{3} 10-500, \mathrm{~V}_{2} \mathrm{O}_{3}<100-5,000, \mathrm{MoO}_{3}<100-500$, and $\mathrm{SnO}_{3}<10-50 .-\mathrm{EBT}$

00087 Goldschmidt, V. M.; Peters, Cl. Zur Geochemie des Bors [The geochemistry of boron (in German)]: Gesell. Wiss. Göttingen Nachr., math.-phys. KI., no. 4, p. $402-407,1932$ b.

A spectrographic method of analyzing for $\mathrm{B}$ is described and data on $\mathrm{B}_{2} \mathrm{O}_{3}$ contents in different rocks are presented. The composite sample of 36 European Paleozoic shales and 2 samples of Dictyonema shale of Ordovician age from Norway each contained 0.1 percent $\mathrm{B}_{2} \mathrm{O}_{3}[311 \mathrm{ppm} \mathrm{B}$ ]. EBT

00088 Goldschmidt, V. M.; Peters, Cl. Zur Geochemie des Germaniums [The geochemistry of germanium (in German)]: Gesell. Wiss. Göttingen Nachr., math.phys. KI., no. 2, p. 14I-166, 1933. 
The spectroanalytical method used to determine $\mathrm{Ge}$ is described and data on $\mathrm{Ge}$ content in different rock types are presented with discussions of the geochemical behavior of $\mathrm{Ge}$. The average $\mathrm{Ge}$ content in clayey shales is $8 \mathrm{ppm} \mathrm{GeO}_{2}$. The average content in the composite sample of 36 European Paleozoic clay shales is $10 \mathrm{ppm} \mathrm{GeO}$ and in the Dictyonema shale of Ordovician age from Hardangervidda, Norway, $10 \mathrm{ppm} \mathrm{GeO}_{2}$.- EBT

00110 Goldschmidt, V. M.; Strock, L. W. Zur Geochemie des Selens II [The geochemistry of selenium II (in German)]: Gesell. Wiss. Göttingen Nachr., math.phys. KI., Geologie u. Mineralogie, v. 1, no. 11, p. 123-142, 1935.

Analyses of sedimentary ore deposits showed $10 \mathrm{ppm}$ Se in the Kupferschiefer, 32 $\mathrm{ppm} \mathrm{Se}$ in mixed ore (Cu rich) from Rammelsberg near Goslar, $26 \mathrm{ppm} \mathrm{Se}$ in gravelly ore from an older bed in Rammelsberg, and $5.6 \mathrm{ppm}$ Se in lead-zinc ore concentrate from Rammelsberg. According to these analyses, Se becomes more enriched as compared to $S$ in sedimentary sulfide beds with copper than in other sedimentary sulfides.-EBT

00112 Goldschmidt, V. M.; Peters, Cl. Zur Geochemie des Bors. II. [The geochemistry of boron (in German)]: Gesell. Wiss. Göttingen Nachr., math.-phys. K1., no. 5, p. $528-545,1932$ c.

Determinations of B contents in eruptive rocks and their minerals, in numerous sedimentary rocks, in sea water, in weathering products and soil, as well as in different kinds of plants and animals are included. B may be an important indicator element of marine sediments. In Paleozoic clay shales the average $\mathrm{B}_{2} \mathrm{O}_{3}$ content was about 0.1 percent. In Recent marine clays it was 0.03 percent.-EBT

00115 Goldschmidt, V. M. Geochemische Verteilungsgesetze und kosmische Häufigkeit der Elemente [Geochemical laws of distribution and the cosmic abundance of elements (in German)]: Naturwissenschaften, v. 18, no. 47-49, p. 999-1013, 1930.

Geochemical laws and the distribution of elements in the upper lithosphere, hydrosphere, and meteorites are discussed. Included are analyses of 10 deep-sea sediments for $\mathrm{Ag}$. The $\mathrm{Ag}$ content ranged from 0.01 to $0.23 \mathrm{ppm}$ and averaged $0.11 \mathrm{ppm} .-\mathrm{EBT}$

00116 Goldschmidt, V. M. Geochemistry: Oxford, Clarendon Press, 730 p., 1954.

Much information pertinent to black shales, including data from the literature and unpublished data on the Kupferschiefer and other European black shales, is included. Concentrations of $\mathrm{Cu}$ have often been observed in black shales, although usually not in as great amounts as in the Kupferschiefer at Mansfeld (2.9 percent). In Ordovician black shales in Norway and Sweden, $\mathrm{Cu}$ contents of $1,000 \mathrm{ppm}$ are common. The black, sulfide-bearing Dictyograptus shale (Lower Ordovician) contains $0.05-0.1 \mathrm{ppm} \mathrm{Au}, 0.6-1.7 \mathrm{ppm} \mathrm{Ag}, 22 \mathrm{ppm} \mathrm{Ga}$, and 1,000-3,000 ppm V. The Upper Cambrian Alum shale contains 0.6-1 ppm Ag. Au and Ag are found to be concentrated in the black mud formed under anaerobic conditions in Walfish Bay on the coast of southwest Africa. Investigations show the average $\mathbf{P b}$ content in marine shales to be about $20 \mathrm{ppm}$.-EBT

00117 Goldschmidt, V. M.; Berman, H.; Haupmann, H.; Peters, Cl. Zur Geochemie der Alkalimetalle [The geochemistry of the alkali metals (in German)]: Gesell. Wiss. Göttingen Nachr., math.-phys. K1., no. 2, p. 235-244, 1933.

Quantitative determinations of the alkali metals in rocks, minerals, and water are presented and the spectrographic method of analyzing for $\mathrm{Li}, \mathrm{Rb}$, and $\mathrm{Cs}$ described. The composite sample of 36 European Paleozoic clay shales contained $100 \mathrm{ppm}$ $\mathrm{Li}_{2} \mathrm{O}, 400 \mathrm{ppm} \mathrm{Rb}{ }_{2} \mathrm{O}$, and $10 \mathrm{ppm} \mathrm{Cs}{ }_{2} \mathrm{O}$.-EBT

00118 Goldschmidt, V.M.; Peters, Cl. Zur Geochemie des Galliums [The geochemistry of gallium (in German)]: Gesell. Wiss. Göttingen Nachr., math.-phys. Kl., no. 2, p. 164-183, 1931. 


\section{BIBLIOGRAPHY OF MINOR ELEMENTS IN BLACK SHALES}

The occurrence of $\mathrm{Ga}$ in minerals and rocks and the spectrographic method of analysis are described and analyses presented. The average Ga:Al ratio in clayey sediments is about 1:30,000. The Ordovician Dictyonema shale from Oslo, Norway, contained $10-100 \mathrm{ppm} \mathrm{Ga}_{2} \mathrm{O}_{3}$; probably the value is closer to 10 .-EBT

00119 Goldschmidt, V. M.; Peters, Cl. Zur Geochemie des Berylliums [The geochemistry of beryllium (in German)]: Gesell. Wiss. Göttingen Nachr., math.phys. K1., no. 4, p. 360-376, 1932a.

A spectrographic method of analyzing for $\mathrm{Be}$ is described and data on $\mathrm{Be}$ content in minerals and rocks are presented. In clay shales, Recent deep-sea clays, and bauxite, the average $\mathrm{Be}$ content is related to the $\mathrm{Al}$ content. $\mathrm{BeO}$ content in the Ordovician Dictyonema shale from Oslo, Norway, is $<10 \mathrm{ppm}$. BeO content in the composite sample of 36 Paleozoic European shales is $10 \mathrm{ppm}$.-EBT

00111 Gott, G. B.; Erickson, R. L. Reconnaissance of uranium and copper deposits in parts of New Mexico, Colorado, Utah, Idaho, and Wyoming: U.S. Geol. Survey Circ. 219, 16 p., 1952.

Spectrographic analyses of crude oil, asphalt, and bituminous shales show a consistent suite of trace metals including $\mathrm{V}, \mathrm{U}, \mathrm{Ni}, \mathrm{Cu}, \mathrm{Co}, \mathrm{Cr}, \mathrm{Pb}, \mathrm{Zn}$, and $\mathrm{Mo}$. During this reconnaissance 30 deposits of cupriferous sandstone and uraniferous asphaltite were examined. Chemical analysis of nonbituminous black shale of Pennsylvanian and Permian age from the Sangre de Cristo Formation in Coyote Creek district, New Mexico, showed $90 \mathrm{ppm} \mathrm{U,2,000} \mathrm{ppm} \mathrm{V}_{2} \mathrm{O}_{5}$, and 2.15 percent $\mathrm{Cu}$. Semiquantitative spectrographic analyses of black carbonaceous shales showed the following contents (in percent; $X=1-9$ ): Devonian Woodford Shale, Texas, $\mathrm{Fe}$ $\mathrm{X}$., Ti X., Co $0.00 \mathrm{X}$, Cr $0.00 \mathrm{X}$, Cu 0.0X, Mo --, Ni $0.00 \mathrm{X}, \mathrm{Pb} 0.000 \mathrm{X}$, U --, V 0.0X; Devonian New Albany Shale, Ind., Fe X., Ti 0.X, Co $0.00 \mathrm{X}$, Cr 0.00X, $\mathrm{Cu} 0.0 \mathrm{X}$, Mo $0.0 \mathrm{X}$, Ni $0.00 \mathrm{X}$, $\mathrm{Pb} 0.00 \mathrm{X}$, U --, V $0.0 \mathrm{X}$; black shale from Mississippian Spergen Limestone, Ste. Genevieve County, Mo., Fe 0.X, Ti 0.X, Co $0.00 \mathrm{X}, \mathrm{Cr} 0.0 \mathrm{X}, \mathrm{Cu} 0.00 \mathrm{X}$, Mo 0.00X, Ni 0.0X, Pb 0.0X, U X., V 0.X.-Authors' abs., modified.

\section{Grant, C. L. See Ugolini, F. C. 00346}

00089 Grant, G. M. Heavy-metal concentrations of diatomaceous sediments in a stagnant fjord [abs.]: Geol. Soc. America Spec. Paper 76, p. 69, 1964.

The varved, diatomaceous, clayey silts of Saanich Inlet, British Columbia, a stagnant fjord, have been analyzed to study the effect of $\mathrm{H}_{2} \mathrm{~S}$-bearing marine waters on trace element concentrations. Spectrochemical analyses show the following average concentrations (in ppm): Sc 14, Y 22, Ti 2,700, Zr 92, V 66, Cr 59, Mn 320, Co 7, Ni 27, Cu 43, B 61, and (in percent) Fe 2.2. B is most abundant in the sediments that have the highest contents of clay and organic matter. Except for B, these elements are not noticeably affected by the stagnant conditions of the inlet. Mo concentrations in these silts are as high as $70 \mathrm{ppm}$. In marine sediments from adjacent areas, the Mo content is below detection limits (approximately $10 \mathrm{ppm}$ ). The enrichment of Mo in the fjord sediments may be caused by the precipitation of $\mathrm{MoS}_{2}$ in the $\mathrm{H}_{2} \mathrm{~S}$-bearing waters or as a result of biological activity. Mo is known to be a cofactor in various enzymes and to be essential for the growth of many marine organisms.-Author's abs., condensed.

00090 Green, Jack. Geochemical table of the elements for 1953: Geol. Soc. America Bull., v. 64, no. 9, p. 1001-1012, 1953.

See Green, 1959.

00109 Green, Jack. Geochemical table of the elements for 1959: Geol. Soc. America Bull., v. 70, p. 1127-1184, 1959.

The geochemical table of elements for 1959 (revised from Green, 1953) is cast in the framework of a conventional periodic table and contains data for each element on geochemical character, characteristics of the atom and isotopes, mineralogy, value and abundance in different rock types (34 possible catagories), sea water, meteorites, 
and the universe. An extensive bibliography is included. For shales, minor element contents compiled are (in ppm): $\mathrm{Li} \mathrm{60,} \mathrm{Be} \mathrm{7,} \mathrm{B} 120, \mathrm{C} 16,200, \mathrm{~N} \mathrm{1,000,F} \mathrm{500,}$ P 770, S 1,100, Cl 160, Sc 10, Ti 4,400, V 130, Cr 160, Mn 6,700, Co 12, Ni 21, Cu 36, Zn 80, Ga 40, Ge 1.7, As 6.6, Se 0.6, Br 6, Rb 280, Sr 299, Y 33, Zr 200, $\mathrm{Nb} 20$ ?, Mo 0.74, Ag 0.9?, Cd 0.3, In 0.04, Sn 3.5, Sb 0.8, I 1, Cs 7.6, Ba 800, La 40, Ce 30, Pr 5, Nd 18, Sm 5, Eu 1?, Gd 5, Tb 0.9, Dy 4, Ho 1?, Er 2.5, Tm 0.2 ?, Yb 2.2, Lu 0.2?, Hf 4?, Ta 3.5, W 1.8, Re 0.001, Au 0.01-0.1? (black shales), $\mathrm{Hg} \mathrm{0.4}$, T1 0.37, Pb 20, Bi 1?, Po $2.4 \times 10^{-10}$, Ra $1.08 \times 10^{-6}$, Th 11, U 4.1.-EBT

00091 Greensmith, J. T. Preliminary observations on chemical data from some British Upper Carboniferous shales: Jour. Sed. Petrology, v. 28, no. 2, p. 209-210, 1958.

Analyses of shales from paleontologically well defined marine and nonmarine layers show that recognition of past depositional environments from chemistry alone is a doubtful process. The marine layer consists of fine-grained dark-gray highly carbonaceous shale containing abundant shell fragments preserved in coarse calcite and dolomite. High S content (2.44 percent) is from the presence of authigenic pyrite. Organic $\mathrm{C}$ content is 10.93 percent; $\mathrm{CaO}, 10.38$; $\mathrm{MnO}, 0.31$; and $\mathrm{SrO}$, 0.11 percent.-EBT

\section{Grimaldi, F. S. See Rader, L. F. 00248}

00092 Grimbert, Arnold. Sur l'origine des imprégnations uranifèrous des schistes houillers de Saint-Hippolyte (Haut-Rhin) [On the origin of the uraniferous impregnations of the carbonaceous shales of Saint-Hippolyte (Upper Rhine) (in French)]: Soc. Geol. France Bull., 6th ser., v. 6, no. 6, p. 707-712, 1956.

The uraniferous shale of Carboniferous age is generally black or brownish and contains about 15 percent organic C, 13 percent carbonate minerals (principally siderite), 3 percent pyrite, and other sulfides in very small amounts: galena, sphalerite, chalcopyrite, and arsenopyrite. Spectrographic analyses reveal traces of $\mathrm{Mn}, \mathrm{As}, \mathrm{Ag}, \mathrm{Ni}, \mathrm{V}, \mathrm{Bi}, \mathrm{Ti}$, and $\mathrm{Sn}$. The hypothesis of a sedimentary origin for the $U$ mineralization in the carbonaceous shales should not be eliminated in spite of the presence of sulfides which, classically, are considered hydrothermal. The $\mathrm{U}$ was probably deposited in basins with reducing environments caused by periods of intense evaporation and the accumulation of organic matter.-EBT

00107 Grimbert, Arnold; Carlier, A. Les schistes uranifères du versant alsacien des Vosges Moyennes [The uraniferous shales of the Alsacian side of the Vosges Mountains (in French)]: Alsace-Lorraine, Service Carte Géol. Bull., v. 9, no. 2, 43 p., 1957.

The shales of Carboniferous age on the Alsacian side of the Vosges Mountains are black to brown, thin bedded, platy weathering. They consist of quartz, a little feldspar and mica in a matrix of organic material, and kaolinite and illite cut by veinlets of siderite. Pyrite is abundant in the shales; galena and sphalerite occur occasionally. Some veins contain 12-15 percent U, but the tenor of most of the rock is 1 percent $U$ or less. Spectrographic analyses showed consistent presence of strong traces of $\mathrm{Ni}, \mathrm{Pb}$, and $\mathrm{Zn}$, and traces of $\mathrm{As}, \mathrm{Ag}, \mathrm{Cu}, \mathrm{V}$, and $\mathrm{Bi}$ in the radioactive shales. Some of the $U$ has been concentrated along faults either by ascending hydrothermal solutions or by leaching of surrounding sediments by ground water. Possibly the $U$ was syngenetically deposited in a basin or a series of isolated basins with anaerobic environments. The $U$ is probably adsorbed on clay minerals and organic material.-EBT

Grundulis, V. See Assarsson, G. 00006

Gruner, J. W. See Cloud, P. E., Jr. 00075

Gulbrandsen, R. A. See Davidson, D. F. 00052

00108 Gulbrandsen, R. A. Petrology of the Meade Peak Phosphatic Shale Member of the Phosphoria Formation at Coal Canyon, Wyoming: U.S. Geol. Survey Bull. $1111-C$, p. 71-146, 1960. 


\section{BIBLIOGRAPHY OF MINOR ELEMENTS IN BLACK SHALES}

The Meade Peak Phosphatic Shale Member of the Permian Phosphoria Formation in Coal Canyon, western Wyoming, is $143 \mathrm{ft}$ thick and consists of dark, thin-bedded phosphorites, carbonates, and quartz-silicate rocks. The average chemical composition is (in percent): $\mathrm{SiO}_{2} 26.5, \mathrm{TiO}_{2} 0.2, \mathrm{Al}_{2} \mathrm{O}_{3} 4.5, \mathrm{Fe}_{2} \mathrm{O}_{3}$ 1.8, $\mathrm{MgO} 4.5$, $\mathrm{CaO}$ 27.0, $\mathrm{Na}_{2} \mathrm{O} 0.9, \mathrm{~K}_{2} \mathrm{O}$ 1.6, $\mathrm{P}_{2} \mathrm{O}_{5}$ 10.6, $\mathrm{CO}_{2}$ 13.8, F 1.1, $\mathrm{SO}_{3} 2.0, \mathrm{H}_{2} \mathrm{O} 0.9$, and carbonaceous material 4.8. The vanadiferous zone, $3.5 \mathrm{ft}$ of carbonate quartz silicate rock, averages 0.7 percent $\mathrm{V}_{2} \mathrm{O}_{5}$ and 6.1 percent carbonaceous material; Se content ranges from 90 to $150 \mathrm{ppm}$. U content of the member ranges from 5 to $340 \mathrm{ppm}$ and averages $40 \mathrm{ppm}$. Phosphorite contains concentrations, relative to carbonate and quartz-silicate rocks, of $\mathrm{Ag}, \mathrm{Sr}, \mathrm{Zn}, \mathrm{V}$, and $\mathrm{Ni}$; the quartz-silicate rock contains relative concentrations of $\mathrm{B}, \mathrm{Ti}, \mathrm{Zr}, \mathrm{V}, \mathrm{Mo}, \mathrm{Mn}$, and $\mathrm{Ni}$.- EBT

00093 Gulyayeva, L. A. Iodine in the sedimentary rocks of the Devonian Period [in Russian]: Akad. Nauk SSSR Doklady, v. 80, p. 787-789, 1951; abs., Chilean Iodine Educ. Bur., 1956.

Average values for I content of 4 samples of limestone, 22 of clay, and 22 of sandstone of all Devonian stages are, respectively, 3.9, 3.9, and $2.5 \mathrm{ppm}$. Clays and sandstones of the Upper and Middle Devonian have usually a slightly higher I content than those of the Lower Devonian. A considerable quantity (often more than 50 percent) of the I was in the form of water-soluble substances.-Chilean Iodine Educational Bureau abs.

00094 Gulyayeva, L. A.; Itkina, E. S. Galogeny i vanadiy, nikel' i med' y uglyakh [Halogens and vanadium, nickel and copper in coals (in Russian; English abs.)]: Geokhimiya no. 4, p. $345-355$, 1962a; English translation: Geochemistry, no. 4, p. $395-407,1962$ [1963].

Halogens, $\mathrm{V}, \mathrm{Ni}$, and $\mathrm{Cu}$ contents were studied in continental, littoral, and lacustrinesapropel coals and in marine-plankton bitumen. These contents in ashes of coals, bitumens, petroleums, and oil shales can be used to determine genesis and environment of deposition. In continental coals Br:I ratio is $<1$; in marine, $>1$. $\mathrm{V}, \mathrm{Ni}$, and $\mathrm{Cu}$ contents are 1,000-10,000 times greater in ash of Domanik (Upper Devonian) bitumen than in coal ashes. Average halogen contents in nearshore marine coal (Carboniferous age) are (in ppm): $\mathrm{Cl}_{\text {mineral }}$ 94, $\mathrm{Cl}_{\text {organic }} 927, \mathrm{~F} 170$, $\mathrm{Br} 112$, I 9.5; in its ash, $\mathrm{Cl}_{\text {meneral }} 1,403, \mathrm{Cl}_{\text {organic }} 13,830, \mathrm{~F} 2,537, \mathrm{Br} 167$, I 142; in marine bituminous rock (Domanik), F $120, \mathrm{Br} 8.6$, I 6.7; in its ash, F 10,526, Br 754, I 587. Metal contents in ash of the nearshore coal are (in ppm): V nd78 , Ni nd-16, $\mathrm{Cu} 10-27$; in ash of Domanik bitumen, $\mathrm{V} 29,800, \mathrm{Ni} 3,950$, and $\mathrm{Cu}$ 2,190.-EBT

00106 Gulyayeva, L. A.; Itkina, E. S. Galogeny v morskikh i presnovodnykh otlozheniyakh [Halogens in marine and fresh-water sediments (in Russian)]: Geokhimiya, no. 6, p. 524-528, 1962b; English translation: Geochemistry, no. 6, p. $610-615,1962$ [1963].

Marine rocks rich in organic substances are 2 to 6 times richer in $I$ and 4 to 15 times richer in $\mathrm{Br}$ than fresh-water continental clays equally rich in organic matter. Marine shales of Domanican [Upper Devonian] deposits from Bashkiria and Kuibyshev areas contained 5.15 percent organic material, $3.4 \mathrm{ppm} \mathrm{I}, 17.1 \mathrm{ppm} \mathrm{Br}$, and $1,100 \mathrm{ppm} \mathrm{Cl}$. Marls from the same deposits contained 6.15 percent organic matter, $2.1 \mathrm{ppm} \mathrm{I}, 13.5 \mathrm{ppm} \mathrm{Br}$, and $600 \mathrm{ppm} \mathrm{Cl}$.-EBT

00095 Gunning, H. C.; Carlisle, Donald. Vanadium on the west coast of British Columbia: Western Miner, v. 17, no. 10, p. 39-43, 1944.

As much as 3 percent $\mathrm{V}_{2} \mathrm{O}_{5}$ and 2 percent $\mathrm{Cu}$ occur in thin wavy laminated layers $<1 \mathrm{ft}$ thick of hard black sediment between flows of basaltic lava in the Valdes Group of probable Triassic age on the west coast of British Columbia. The laminae consist of alternating black opaque material and tiny spherules of quartz. The black sediment is locally replaced by epigenetic chalcocite and cut by tiny quartz veins containing specks of chalcocite. The $\mathrm{V}$ appears syngenetic, either concentrated by organic material or precipitated chemically with the sediment. Some of the basalt flows with the sediments contain as much as 0.3 percent $\mathrm{V}_{2} \mathrm{O}_{5}$. Analyses of the sediment show (in percent): $\mathrm{SiO}_{2} 75.31, \mathrm{FeO} 2.29, \mathrm{Al}_{2} \mathrm{O}_{3} 3.70, \mathrm{TiO}_{2} 0.15, \mathrm{MnO}$ 
$0.10, \mathrm{CaO} 4.08, \mathrm{MgO} 0.53, \mathrm{Cu} 2.88, \mathrm{~V}_{2} \mathrm{O}_{5} 2.16, \mathrm{~S} 0.72, \mathrm{P}_{2} \mathrm{O}_{5}$ tr, $\mathrm{U}$ and $\mathrm{Cr}$ nd, $\mathrm{H}_{2} \mathrm{O} 2.61, \mathrm{C}$ and $\mathrm{CO}_{2}$ present ( $\mathrm{C}$ about 5 percent by calculation; no hydrocarbons detected).-EBT

Hagen, Hannelore. See Cloud, P. E., Jr. 00075

Hagner, A. F. See Beath, O. A. 00013

00105 Hallam, A.; Payne, K. W. Germanium enrichment in lignites from the Lower Lias of Dorset: Nature, v. 181, no. 4614, p. 1008-1009, 1958.

The Lower Lias of Dorset consists of a series of marine shales, marls, and subsidiary limestones, about $170 \mathrm{~m}$ thick. Lignite fragments, which probably originated as coniferous driftwood, are scattered throughout the beds, but are more common in the "Grey Ledge" at the top of the Blue Lias and in the "Woodstone" of the Black Ven Marls. Lignites can be grouped into 2 main varieties: woodlike and jet. Both varieties have similar $\mathrm{Ge}$ contents. Maximum $\mathrm{Ge}$ concentration in the lignites is 0.93 percent, in their ash, 8.4; minimum concentration, lignites 0.024 , ash 0.026 ; mean, lignite 0.18 , ash 1.48 percent. Mean Ge concentrations in the parent rocks are (in ppm): shale 1.7, marl 2.5, limestone 3.9, and pyrite 2.4. No correlation was found between $\mathrm{Ge}$ contents of lignites and those of parent rocks. Ge was probably introduced after burial by circulating solutions.-EBT

00096 Harańczyk, C. Investigations of copper-bearing Zechstein shales from the Wroclaw monocline (Lower Silesia) (in English): Acad. Polonaise Sci. Bull., Sér. Sci. Géol. et Géog., Warsaw (Varsovie) Poland, v. 12, no. 1, p. 13-18, 1964a.

The Permian Zechstein [Kupferschiefer] rocks are transitory between carbonate and clayey types. The typical copper-bearing shale is an almost black, compact rock of strong luster, weakly developed fissility, uneven fracture. The shales are comprised of clay minerals impregnated with organic substances and accompanied by pelitic sulfide minerals, principally $\beta$-chalcocite, bornite, chalcopyrite, and pyrite. A sample of shale almost free from carbonates had the following composition (in weight percent): $\mathrm{SiO}_{2} 27.61, \mathrm{Al}_{2} \mathrm{O}_{3}$ 13.19, $\mathrm{FeO} 0.51, \mathrm{Fe}_{2} \mathrm{O}_{3}$ 0.41, $\mathrm{FeS}_{2}$ 0.43, organic

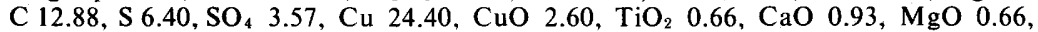
$\mathrm{CO}_{2} 1.37, \mathrm{H}_{2} \mathrm{O} 0.81, \mathrm{H}_{2} \mathrm{O}^{+} 0.79, \mathrm{~K}_{2} \mathrm{O} 2.94, \mathrm{Na}_{2} \mathrm{O} 0.42, \mathrm{~V} 0.125, \mathrm{P}_{2} \mathrm{O}_{5} 0.06$, As 0.09 , Ni 0.055 , Co $0.055, \mathrm{Cr} 0.05$, and $\mathrm{Mo} 0.008$. Spectral analysis revealed trace amounts of $\mathrm{Pb}, \mathrm{Zn}, \mathrm{Ag}, \mathrm{Zr}, \mathrm{Ba}, \mathrm{Sr}, \mathrm{Sn}, \mathrm{Sb}, \mathrm{Bi}, \mathrm{Tl}, \mathrm{Re}, \mathrm{Be}, \mathrm{Sc}$, and rare earths.EBT

00097 Harańczyk, C. Petrographic classification of the Zechstein copper-bearing rocks from Lower Silesia (in English): Acad. Polanaise Sci. Bull., Sér. Sci. Géol. et Géog., Warsaw (Varsovie) Poland, v. 12, no. 1, p. 19-25, 1964b.

Chemical analyses of the Permian Zechstein copper-bearing shales [Kupferschiefer], which grade into carbonate rocks, show these rocks to contain a wide range in major constituents. A statistical diagram of 100 chemical analyses of samples representing the "shaly" series yields data on occurrence and differentiation of various shales. Gradual transitions from shale to dolomite or from shale to limestone do not influence the mineralization of the shales. A constant relation exists between the organic matter and the $\mathrm{Cu}$ contents in the Wroclaw monocline. The chemical composition of the copper-bearing shales is plotted in projection using a binary system and on the tetrahedron diagram of sedimentary rock classification proposed by Pettijohn.-EBT

00099 Harder, Hermann. Beitrage zur Geochemie des Bors [Contribution to the geochemistry of boron (in German)]: Fortsch. Mineralogie, Stuttgart, v. 37, no. 1, p. 82-87, 1959a.

Rocks and minerals were analyzed spectrographically with an error of \pm 15 percent. The Kupferschiefer was found to contain $240 \mathrm{ppm} \mathrm{B}$; a composite sample of 36 European Paleozoic shales, $95 \mathrm{ppm}$, and Recent deep-sea sediments, an average of $250 \mathrm{ppm}$. The B content in sediments somewhat increases with higher 
carbonaceous-material content. Metamorphic processes lower B content in rocks.EBT

00100 Harder, Hermann. Bor in Sedimenten, Teil 2 von Beitrag zur Geochemie des Bors [Boron in sediments, pt. 2 of Contribution to the geochemistry of boron (in German)]: Akad. Wiss. Göttingen Nachr., Math.-Phys. KI., no. 6, p. 123-183, $1959 \mathrm{~b}$.

B content of sedimentary rocks depends on grain size (B content decreases with increasing grain size); salinity of depositional environment; amounts of clay minerals, such as illite, which contain B in their crystal lattices; source of the illite, whether detrital or authigenic (B contents are generally higher in authigenic illite); the organic-matter content; and the degree of metamorphism (B decreases with increasing metamorphism). Gray clays associated with evaporite deposits contain more than $2,000 \mathrm{ppm} \mathrm{B}$; normal marine clays do not contain more than $500 \mathrm{ppm}$ B. High B contents in organic-rich rocks such as the Kupferschiefer (185-240 ppm) may be due to the association of B with organic matter; some coal ashes have high amounts of $B$. The inean B content in ancient clays is about $100 \mathrm{ppm}$; in sediments, excluding deep-sea sediments $(130-190)$, it is about $85 \mathrm{ppm}$. Illite in sediments is a great geochemical reservoir of B in the rock cycle.-EBT

00101 Harder, Hermann. Das Bor im Kreislauf der Gesteine [Boron in the rock cycle (in German: English abs.)]: Internat. Geol. Cong., 21st, Copenhagen, 1960 Rept., sec. 1, pt. 1, p. 10-13, 1960 .

Recent spectroscopic investigations show that all basic rocks have low B contents $(5 \mathrm{ppm})$. Sediments are richer in B $(85 \mathrm{ppm})$, but B is not equally distributed; most of it is in fine-grained clays. Illites contain most of the B; contents vary depending on origin and conditions of deposition (saliniferous clays contain as much as $2,000 \mathrm{ppm} \mathrm{B}$, marine clays some $100 \mathrm{ppm}$, and terrestrial clays about $50 \mathrm{ppm}$ ). New analyses of different clays, predominantly from Germany, showed the following mean values of $\mathbf{B}$ (in $\mathrm{ppm}$ ): Algonkian [Precambrian] shale 70, Paleozoic shale 90, Mesozoic shale 150, and Recent deep-sea clays 200 . The lower B content in the older sediments is mainly due to the increased amount of diagenesis and metamorphism with time.-Author's abs., modified.

Haskin, Larry. See DeGrazia, A. R. 00049

00102 Haskin, Larry; Gehl, M. A. The rare-earth distribution in sediments: Jour. Geophys. Research, v. 67, no. 6, p. 2537-2541, 1962.

Neutron activation analyses confirm the constancy of the relative abundances of rare-earth elements for most sediments, as found by E. Minami (1935b). Possible reasons for the difference in the sediment and chondrite rare-earth distributions are considered. Table 1 shows the results of rare-earth analyses (in $\mathrm{ppm}$ ) of sediments and one chondrite. The accuracy and precision of these values are \pm 5 to 10 percent. Values found for the Muncie Creek Shale Member of the Iola Limestone, a black shale of Pennsylvanian age from Kansas, are (in ppm): Y 18, La 20, Pr 6, Nd 16, Sm 5.6, Eu 1.1, Gd 4.3, Tb 0.58, Ho 0.605, Er 1.9, Tm 0.28, $\mathrm{Yb}$ 1.8, and Lu 0.33. - EBT

Haskin, Larry. See Wildeman, T. R. 00314

Haupmann, H. See Goldschmidt, V. M.00117

00103 Hecht, Friedrich; Tomic, E. Uranforschung in Osterreich [Uranium research in Austria (in German)]: Osterreich. Chemiker-Zeitung, v. 58, no. 19/20, p. 221-227, 1957.

$\mathrm{U}$ analyses are given for 115 samples of natural waters, oil, river sands, coal, bauxite, and oil shales. U content in lower Laussa black shale samples ranges from 5.5 to $97 \mathrm{ppm}$. A sample of oil shale from the Seefeld Shale of Norian age [Triassic] in Tyrol showed a U content of $27.6 \mathrm{ppm}$.-EBT 
Heezen, B. C. See Ericson, D. B. 00044

00404 Heide, F.; Korner, D. Zur Geochemie des Germaniums [The geochemistry of germanium (in German)]: Chemie der Erde, v. 23, no. 1, p. 104-115, 1963.

At the present, probable values for the Ge concentrations in materials associated with the secondary cycle of this element are [only material pertinent to black shale quoted]: black shale, $1.8 \mathrm{ppm}$; pelagic clay $2.0 \mathrm{ppm}$.-A A thors' abs., condensed.

Heller, S. See Gil-av, E. 00120

Henderson, D. M. See Moore, D. M.00149

00104 Higazy, R. A.; Hussein, H. A.-M. Remarks on the uranium contents of some black shales and phosphates from Kesseir and Safaga: Egyptian Acad. Sci. Proc., v. 11, p. 63-66, 1955 [1956].

The phosphatic deposits of Late Cretaceous age of Kosseir and Safaga are associated with black shales which range from $40 \mathrm{~cm}$ to $1 \mathrm{~m}$ in thickness. Mícroscopically, these are composed of disseminated organic matter, ferruginous substances, clay, and occasional detrital quartz. Microforaminifers are rare and show replacement by pyrite. The $U$ content in the studied black shales ranges from 1 to $32 \mathrm{ppm}$, averaging $16 \mathrm{ppm}$ in the Kosseir samples and $8.6 \mathrm{ppm}$ in the Safaga samples. The samples contain little sulfide, but much carbonate, which may explain their low U content compared to black shales from the U.S.A. and the U.S.S.R. The phosphates usually contain more $U$ than the black shales. The $U$ in the phosphates seems to be adsorbed on collophanite, whereas in black shales it is adsorbed on the organic matter.-EBT

00085 Hirst, D. M.; Dunham, K. C. Chemistry and petrography of the Marl Slate of S.E. Durham, England: Econ. Geology, v. 58, no. 6, p. 912-940, 1963.

The Marl Slate, the bottom member of the Permian Zechstein in eastern Durham is a calcitic- or dolomitic-bituminous siltstone ranging in thickness from 9 in. to $13 \mathrm{ft}$. It is equivalent to the Kupferschiefer of Germany. The average amounts of $\mathrm{Mo}, \mathrm{Co}$, and $\mathrm{Ni}$ suggest slow sedimentation. The antipathetic variation of these elements with rate of deposition suggests incorporation by sorption of dissolved ions on organic carbon and clay. Normal weathering of the land surface probably accounts for $\mathrm{Zr}, \mathrm{Sr}, \mathrm{Rb}, \mathrm{Mo}, \mathrm{Co}, \mathrm{Ni}$, and $\mathrm{Mn}$ and some of the $\mathrm{Cu}$. A fluctuating source is required for $\mathrm{Pb}, \mathrm{Zn}, \mathrm{Ba}$, and the remaining $\mathrm{Cu}$, which may be better accounted for by the introduction of metals intermittently into the lagoon by submarine springs than by truly epigenetic mineralization. The range of the average trace-element content in 4 cores is (in ppm): Mo 137-341, $\mathrm{Sr} 162-360, \mathrm{Zr} 70-$ 112, Rb 75-131, Pb 161-571, Cu 69-310, Ni 146-284, Co 15-141, Zn 19-82. Authors' abs., modified.

00098 Hirst, D. M. The geochemistry of modern sediments from the Gulf of PariaII The location and distribution of trace elements: Geochim. et Cosmochim. Acta, v. 26, p. 1147-1187, 1962.

Analyses for minor elements in modern sediments from the Gulf of Paria, west of Trinidad, suggest that $\mathrm{Ga}, \mathrm{Cr}, \mathrm{V}, \mathrm{Cu}, \mathrm{Pb}, \mathrm{Ba}, \mathrm{Ti}, \mathrm{Li}$, and, to a lesser extent, $\mathrm{Co}, \mathrm{Ni}$, and $\mathrm{B}$ probably were deposited with degraded clay minerals, structurally combined in their lattices. Nondetrital $\mathrm{Ga}, \mathrm{Cr}, \mathrm{V}, \mathrm{Co}, \mathrm{Ni}, \mathrm{Cu}, \mathrm{Pb}, \mathrm{Sn}$, and possibly $\mathrm{Be}$ and $\mathrm{Mo}_{\mathrm{o}}$ are concentrated in near-shore areas. This concentration is possibly related to adsorption onto clay minerals which are flocculating due to changes in salinity and perhaps also to association with organic $\mathrm{C}$ and limonitic concretions or calcareous detritus on the platforms. Control by organic $\mathrm{C}$ may be significant for nondetrital $\mathrm{Ga}, \mathrm{Cr}, \mathrm{V}, \mathrm{Ni}, \mathrm{Cu}$, or $\mathrm{Mo}$. The range of minor-element contents in clays from the Gulf is (in ppm): Ba 255-515, Sr 100-312, V 74-151, Cr 6199. Co 9.8-13, Ni 22-34, Zr 115-350, Mo---, Be 1-8.7, Ag 1, Ga 8.7-24, Pb 1332, Cu 15-23, Li 26-94, Rb 93-177, Cs 5.3-13, and B 54-90.-Author's abs., modified.

00183 Holland, H. D.; Kulp, J. L. The transport and deposition of uranium, ionium and radium in rivers, oceans, and ocean sediments: Geochim. et Cosmochim. Acta, v. 5, p. $197-213,1954$. 
Concentration of radioelements in the ocean is controlled by rates of influx, radioactive decay, and sedimentation. Oceanic oozes contain the greatest concentration of $\mathrm{Ra}$, whereas shelf sediments contain the most $\mathrm{U}$. Shelf sediment contains $0.8 \times 10^{-6} \pm 0.2 \times 10^{-6} \mathrm{ppm} \mathrm{Ra}$ and $3 \pm 1 \mathrm{ppm} U$, whereas radiolarian ooze contains $13 \times 10^{-6} \pm 2.5 \times 10^{-6} \mathrm{ppm} R$ a and $1 \pm 1 \mathrm{ppm} U$. This relation reflects a greater amount of $U$ added during sedimentation of shelf sediment.- JDV

Holser, W. T. See Warner, L. A. 00339

Honda, M. See Merrill, J. R. 00148

Hopkins, M. E. See Ostrom, M. E. 00267

Horne, J. W. See Thorne, H. M.00287

00224 Horstman, E. L. The distribution of lithium, rubidium and caesium in igneous and sedimentary rocks: Geochim. et Cosmochim. Acta, v. 12, p. 1-28, 1957.

$\mathrm{Li}, \mathrm{Rb}$, and $\mathrm{Cs}$ have been determined by a flame photometric method in 186 samples, and $\mathrm{Rb}$ and $\mathrm{Cs}$ in an additional 53 samples, representing sedimentary and igneous rocks from geographically diverse areas and ranging in age from Precambrian to Recent. Marine shales contain an average of $72 \mathrm{ppm} \mathrm{Li}, 140 \mathrm{ppm} \mathrm{Rb}$, and $5 \mathrm{ppm}$ Cs. Li is largely retained in the products of weathering because of its concentration in clay minerals. $\mathrm{Rb}$ is retained during weathering by those clays having a structural position for the ion, although adsorption is important in both clays and shales. $\mathrm{Cs}$ and $\mathrm{Rb}$ behave similarly in the geochemical cycle.-EBT

Huffman, Claude, Jr. See Tourtelot, H. A. 00282

Hurley, P. M. See Whitney, P. R. 00313

Hussein, H. A.-M. See Higazy, R. A. 00104

00184 Hyden, H. J.; Danilchik, Walter. Uranium in some rocks of Pennsylvanian age in Oklahoma, Kansas and Missouri: U.S. Geol. Survey Bull. 1147-B, 82 p., 1962.

The distribution of $U$ and other trace elements in sedimentary rocks of Middle Pennsylvanian (Des Moines) age in Oklahoma, Kansas, and Missouri was studied. The average $U$ content of each of 6 carbonaceous shale units ranges from 20 to $50 \mathrm{ppm}$. $U$ is concentrated in phosphate nodules found in black shale; $U$ content in these ranges from 20 to $600 \mathrm{ppm}$. No unusual amounts of other trace elements were found in the black shales, but the phosphate nodules contain rare earths, including $\mathrm{Dy}, \mathrm{Er}$, and $\mathrm{Nd}$, in concentrations that directly correlate with $\mathrm{P}_{2} \mathrm{O}_{5}$ contents. Semiquantitative spectrographic analyses of the black shales show the following range in minor element content (in ppm): Ti 1,500-3,000, $\mathrm{P}<700-7,000$, Mn 15-1,500, Ag $0.7-3$, B $150-300$, Ba $70-1,500$, Be 0.7-1.5, Co $15-30$, Cr 70$300, \mathrm{Cu} 70-700, \mathrm{Ga} 15-70$, La $<30-70$, Mo $<5-30$, Ni $150-300, \mathrm{~Pb} 15-150$, Sc 15 , Sn $<10-15$, Sr 70-300, V 70-700, Y 15-30, Yb $1.5-3, \mathrm{Zn}<80-700$, and $\mathrm{Zr} 15-$ 70.--Authors' abs., modified.

Ionesi, L. See Savul, Mircea. 00233

Ismatullaev, Kh. K. See Amirkhanov, Sh. Kh. 00023

Itkina, E. S. See Gulyayeva, L. A. 00094

Itkina, E. S. See Gulyayeva, L. A. 00106

00220 Itkina, E. S. Distribution of copper in sedimentary rocks of the oil-bearing regions of Azerbaijan [in English]: Akad. Nauk SSSR Comptes rendus (Doklady), v. 51, p. $43-46,1946$.

A brief description of the results of our study of the $\mathrm{Cu}$ content in 70 samples of sedimentary rocks taken from wells and outcrops in the oil fields of the Apsheronian peninsula is presented. The highest $\mathrm{Cu}$ content occurred in samples 
from the Maikopian Series [Tertiary] (47.3 ppm) and from the Barremian series (57.2 ppm) and from the Cretaceous (Yunusdag, Albian, Aptian) (16.5 ppm). Figures for the Barremian are given apart from those of the other Cretaceous series because of their marked difference. No direct relation between $\mathrm{Cu}$ and $\mathrm{C}$ contents is apparent in this region. A dark-gray shale from the Kirmakinsky horizon contains $38.3 \mathrm{ppm} \mathrm{Cu}$ and 0.88 percent $\mathrm{C}$; a dark-gray shale from the Maikop contains 64 ppm $\mathrm{Cu}$ and 3.03 percent C.--EBT

00221 Itkina, E. S. Med' v osadochnykh porodakh kamennougol'nykh otlozheniy neftenosnykh rayonov Uralo-Povolzh'ya [Copper in sedimentary rocks of the Carboniferous deposits of the petroleum regions of Ural-Volga (in Russian)]: Akad. Nauk SSSR Doklady, v. 62, p. 357-360, 1948.

$\mathrm{Cu}$ was found in all horizons of Carboniferous age in sedimentary rocks that contained organic matter, but not in bitumen-free limestone. The $\mathrm{Cu}$ occurs mainly in the argillaceous and arkosic fractions. Increased amounts of $\mathrm{Cu}$ in the series correspond to an increase in average thickness of the series. Carbonaceous shale and coal from the Krasnokamski region contain $34.3 \mathrm{ppm} \mathrm{Cu}$; carbonaceous shale from the Tuymazov region, $25.7 \mathrm{ppm}$.--EBT

00222 Itkina, E. S. Yod i brom v paleozoyskikh otlozheniyakh nekotorykh neftenosnykh rayonov Vtorogo Baku [Iodine and bromine in Paleozoic deposits of some petroleum-bearing regions of Second Baku (in Russian)]: Akad. Nauk SSSR, Inst. Nefti, Trudy, v. 9, p. 206-235, 1958.

I and $\mathrm{Br}$ are unequally distributed through Second Baku. I content increases in the rocks of Carboniferous age in Saratovsky, but is generally lacking in the same horizon throughout Tatar. Coal and carbonaceous shale in Tatar are richest in $\mathrm{I}$ and $\mathrm{Br}$. Although a general direct relationship between $\mathrm{C}$ content and $\mathrm{I}$ and $\mathrm{Br}$ was not observed, a proportionality exists if the $\mathrm{C}$ content is less than 5 percent. With an increase of organic $C$ content over 40 percent there is no further increase in $\mathrm{I}$ an'd $\mathrm{Br}$ contents. Part of the $\mathrm{Br}$ and $\mathrm{I}$ in rocks is in salts soluble in $\mathrm{HCl}$ and part is bound with organic matter; the binding of $\mathrm{Br}$ with organic matter is more distinct than that of $\mathrm{I}$. The contents in carbonaceous clays and argillites of Carboniferous age in the areas are (in ppm): Saratovsky, I 10.3, $\mathrm{Br}$ 16.7; Kuybyshevsky, I 2, Br 13; and Tatar, I 0.7, Br 22.9.-EBT

00223 Itkina, E. S.; Lygalova, V. N. Geokhimiya ioda i broma v otlozheniyakh uglenosnogo gorizonta, domanika i bavlinskoi svity nekotorykh neftenosnykh ploshchadeyi Bashkiriy, in Gulyayeva, L. A., ed., Geokhimiya nefti i neftyanykh mestorozhdeniy: Akad. Nauk SSSR, Inst. Geol. i Razrabotki Groiuchikh Iskraemykh, p. 152-159; English translation by S. Caspari, 1964, Geochemistry of iodine and bromine in the Carboniferous horizon and in the Domanik and Bavly Formations of some petroliferous areas of Bashkiria: New York, Danial Davey and Co., Israel Program for Sci. Translations, p. 160-169, 1962.

Carbonaceous shales of Carboniferous age from Bashkiria average $6.8 \mathrm{ppm} \mathrm{I,} 59.5$ ppm $\mathrm{Br}$, and 38.18 percent organic $\mathrm{C}$. The average contents of the Carboniferous horizon, which includes sandstone, clay, argillite, and aleurolite, are $2.2 \mathrm{ppm} \mathrm{I,} 19.7$ ppm Br, and 6.79 percent organic $C$. In rocks containing more than 5 percent $\mathrm{C}$, I content increases with increasing organic $\mathrm{C}$ content. The relationship between $\mathrm{Br}$ and $\mathrm{C}$ is more pronounced; with an increase of organic $\mathrm{C}$ from 0 to more than 20 percent, $\mathrm{Br}$ increases from 11.8 to $59.3 \mathrm{ppm}$. Clays and argillites of the Domanik Formation [Upper Devonian] averaged $1.7 \mathrm{ppm} \mathrm{I,} 25.1 \mathrm{ppm} \mathrm{Br}$, and 3.74 percent organic C. The marls from the Domanik average $1.2 \mathrm{ppm} \mathrm{I,} 16.8 \mathrm{ppm} \mathrm{Br}$, and 6.59 percent organic $\mathrm{C}$. The $\mathrm{Br}$ is somehow linked with the bitumens in the rocks.EBT

00218 Jambor, J. L. Volborthite from British Columbia: Am. Mineralogist, v. 45, p. 1307-1309, 1960.

Volborthite, $\mathrm{Cu}_{3}\left(\mathrm{VO}_{4}\right)_{2} \cdot 3 \mathrm{H}_{2} \mathrm{O}$, is present as a weathering product of a thin, interlava sedimentary rock of Late Triassic age which crops out west of Menzies Bay on Vancouver Island and north of Gowland Harbor on Quadra Island, British Columbia. The vanadium-bearing rock is a black, extremely finely laminated, 
fossiliferous, nonclastic sediment which consists chiefly of carbonaceous matter and microcrystalline to cryptocrystalline quartz. Spectrographic analyses indicate that the carbonaceous material contains $V$. Hypogene chalcocite is generally an additional major constituent of the rock. The maximum reported value of $\mathrm{V}_{2} \mathrm{O}_{5}$ in the sediment is more than 3 percent, but the deposits are generally classified as uneconomic.-EBT

Janda, I. See Brandenstein, M. 00038

00219 Janda, I.; Schroll, E. Geochemische Untersuchungen an Graphitgesteinen [Geochemical investigation of graphitic rocks (in German)]: Internat. Geol. Cong., 21st, Copenhagen, 1960, Rept., pt. 1, Geochemical cycles, p. 40-53, 1960.

An emission spectrographic method was used to determine 26 elements in more than 100 samples of graphite and graphitic rocks. The trace-element content decreased with increased crystallization and with increased coaly-matter content; no trace metals enter the graphite lattice. Probably almost all of the graphite originated from concentrations of organic material, as indicated by the contents of biophile elements like $\mathrm{Mo}, \mathrm{V}, \mathrm{Ni}$, and $\mathrm{B}$. Traces of $\mathrm{Ge}, \mathrm{Be}$, and $\mathrm{Cr}$ indicate origin from coaly rock, whereas $\mathrm{Mo}, \mathrm{Ni}, \mathrm{Co}$, and a high $\mathrm{V}$ content indicate origin from bituminous rock and sapropelite. Average contents found in graphitic shales are (in ppm): As 5, Sb 3, Bi--, Ag 0.05, Cu 192, $\mathrm{Zn} \mathrm{80-230} \mathrm{(clays,} \mathrm{Pb} 20, \mathrm{Hg}$ -, Ge 7, Mo not reported, V 120, Ni 24, Co 8, Ga 50, Tl --, Cr 410-680, Ti 4,300, Sn 40, Zr 120, Mn 620, Be 3.6, B--, Sr 170, and Ba 460.-Authors' abs., modified.

Jeanrenaud, P. See Savul, Mircea. 00233

Joensuu, Oiva. See Landergren, Sture. 00176

00185 Joensuu, Oiva; Olausson, Eric. Barium content in deep-sea cores and its relationship to organic matter [abs.]: Geol. Soc. America Spec. Paper 76, p. 8687, 1964.

The dark and light layers of Swedish cores 190 and 194 from the Mediterranean were analyzed for trace and major elements. Carbonates were leached out and the remaining silicates separated into clay-, silt-, and sand-sized fractions. Waterinsoluble organic matter was included in the clay fraction. Organic matter was ashed at $500^{\circ} \mathrm{C}$ and the residue analyzed. $\mathrm{Ba}$ and Mo contents varied the most between dark and light layers (light clay and silt: Ba $250 \mathrm{ppm}$, Mo $<5 \mathrm{ppm}$; dark clay and silt: as much as $5,000 \mathrm{ppm} \mathrm{Ba}$ and $90 \mathrm{ppm} \mathrm{Mo}$ ). During sedimentation of the light layer enough oxygen was available to decompose the organic matter (through biologic activity). During glacial stages the water level of the Mediterranean fell so that water exchange with the Atlantic was greatly reduced which resulted in a stagnant environment that prevented oxidation of organic matter.-Authors' abs., condensed.

Joensuu, Oiva. See Koczy, F. F. 00211

00186 Joly, John. The amount of thorium in sedimentary rocks. 2. Arenaceous and argillaceous rocks: Philos. Mag., v. 20, ser. 6, p. 353-357, 1910.

Sedimentary rocks in general contain $11.6 \mathrm{ppm}$ Th. Mean Th content in argillaceous sediments is $11.4 \mathrm{ppm}$. A black shale of Silurian and Ordovician age contained 10 ppm Th.-EBT

00187 Jost, Konrad. Uber den Vanadiumgehalt der Sedimentgesteine und sedimentären Lagerstätten [On the vanadium content of sedimentary rocks and sedimentary ore deposits (in German)]: Chemie der Erde, v. 7, p. 177-290, 1932.

Literature on $\mathrm{V}$ is reviewed, analytical methods are described, analyses of sedimentary rocks ranging in age from Silurian to Recent are presented, and the geochemistry of $\mathrm{V}$ is discussed. Average $\mathrm{V}$ content in clays and shales is calculated as $121 \mathrm{ppm}$. V content of bituminous shales from the Lias $\epsilon$ profile of Ohmenhausen near Reutlingen ranges from 107 to $240 \mathrm{ppm}$ (error \pm 5 percent). $V$ contents in some carbonaceous rocks are (ppm): bituminous marl, Permian Kupferschiefer, 
Mansfeld, 530; bituminous marly shale, Lias, Grenze $\delta / \epsilon$, Wurttemberg, 166; very bituminous marly shale, Lias $\epsilon$, Reutlingen, 440; very bituminous marly shale, Lias $\epsilon$, Erzingen, 345; mud with organic residues, Recent, Volga River, 220.-EBT.

Kalmurzaev, K. E. See Adyshev, M. M. 00002

00181 Katchenkov, S. M. Raspredeleniye khimicheskikh elementov v glinistykh mineralakh [The distribution of chemical elements in clay minerals]: Akad. Nauk SSSR, Doklady, v. 134, no. 3, p. 680-683, 1960; English translation: New York Consultants Bur., Inc., p. 849-851, 1961.

Clay samples were taken from both monomineral deposits and from sedimentary deposits, including erosion crusts, Paleozoic deposits of the Russian platform, Mesozoic and Cenozoic deposits of the northeast Caucasus, and mud from Recent sediments of the Black Sea, Caspian Sea, Sea of Okhotsk, Bering Sea, and Indian Ocean. The $<1 \mu$ fraction was separated and its mineralogy determined by $\mathrm{X}$-ray and thermal methods. Minor elements were determined by quantitative spectral analysis, common elements and organic $\mathrm{C}$ by chemical analysis, and bitumen by luminescent analysis. The distribution of many elements in clay minerals depends on physicochemical properties of the element, environment of formation of the mineral, composition of parent rocks, and intensity of chemical weathering (climate). Ratios of element pairs show these differences between minerals of continental and of marine deposits. In clay minerals of marine deposits, minor element content is (in ppm): Sr 250, Ba 220, Mn 300, V 140, Cr 150, Ni 70, Cu 30, Zr 140, Be 0.8 , organic $C 15,000$, bitumen 870 ; in clay minerals of Recent marine sediments: Sr 370, Ba 360, Mn 760, V 146, Cr 126, Ni 90, Cu 50, Zr 100, Be 1, organic C 16,500, bitumen 680; in clay minerals of continental sediments: $\mathrm{Sr} 190, \mathrm{Ba} 200$, Mn 500, V 170, Cr 150, Ni 100, Cu 20, Zr 150, Be 1.2, organic C 13,300, bitumen 300.-EBT

00182 Katchenkov, S. M. K kharakteristike usloviy osadkonakopleniya po rasseyannym khimicheskim elementam [Characteristic conditions of sediment accumulation according to dispersed chemical elements (in Russian)]: Vses. Neft. nauchno issledov. Geol.-razved. Inst. [Leningrad], Trudy, No. 174 (Geokhim. Sb. 7), p. 109$154,1961 \mathrm{~b}$.

Distribution patterns of elements in sedimentary rocks are shown graphically for different sediments, environments, fractions, and minerals. During mechanical sorting, clay fractions are enriched in $\mathrm{V}, \mathrm{Cr}, \mathrm{Ni}, \mathrm{Mg}, \mathrm{Be}, \mathrm{Cu}$, and $\mathrm{Ti}$, and are combined with $\mathrm{Na}, \mathrm{Ca}, \mathrm{Sr}, \mathrm{Mn}$, and $\mathrm{Ba}$, whereas in sand-aleurite fractions, $\mathrm{Na}$, $\mathrm{Ca}, \mathrm{Sr}$, and $\mathrm{Mn}$ are present as carbonates or partially sorbed. In silt fractions, high contents of $\mathrm{Ti}, \mathrm{Cr}, \mathrm{Zr}, \mathrm{V}, \mathrm{Ni}, \mathrm{Cu}$ are due to their presence in magmatic minerals. In lakes, reservoirs, northern seas, where chemical weathering is weak, a motley distribution of elements results. In closed and semiclosed marine basins the distribution of elements is more orderly. Distribution patterns result from many factors concerning mechanical and chemical differentiations during sedimentation such as climate of the area of deposition, relief and size of drainage basin area, and chemical and physical properties.-Referativnyy Zhur., 1962, no. 5A67, modified.

00188 Katchenkov, S. M. Raspredeleniye elementov v glinakh paleozoya VolgoUral'skoy oblasti [Element distribution in Paleozoic clays of the Volga-Ural region]: Akad. Nauk SSSR, Doklady, v. 107, p. 115-118, 1956; English translation: New York, Consultants Bur., Inc., p. 9-13, 1956.

Data on the distribution of chemical elements in 279 samples of Paleozoic clays from the Volga-Ural region show that concentrations and ratios of pairs of elements with similar physicochemical properties do not remain constant. The changes depend on tectonic processes which occurred in the Russian platform during Paleozoic time and on environment of deposition and organic life. Accumulation of $\mathrm{Cu}, \mathrm{V}$, and $\mathrm{Cr}$ in Lower Carboniferous clays is related to increased organic content. Accumulation of $\mathrm{Ni}$ depends less on the quantity of organic material, therefore its content varies less through the Carboniferous sediments. This can be seen with the increase in the $\mathrm{V}: \mathrm{Ni}$ ratio with increasing organic content. The producing (Pashisian) zone of the Devonian, the Tulian and other Lower 
Carboniferous horizons, and Upper Permian deposits are considerably more enriched in organic matter (petroleum and plant residues) than other horizons of the Paleozoic. Range of minor element contents in these horizons is (in ppm): Sr 230-440, Ba nd-520, Mn 100-730, Cr 50-210, Ni 50-80, Cu 20-90, V 120-190.EBT

00189 Katchenkov, S. M. Malye khimicheskiye elementy $\mathrm{v}$ osadochnykh porodakh i neftyakh [Minor chemical elements in sedimentary rocks and oils (in Russian)]: Vses. Neft. nauchno-issledov. Geol.-razved. Inst. [Leningrad], Trudy, v. 143, 271 p., 1959.

Data on minor element contents in sedimentary rocks and petroleums, ranging in age from Cambrian to Recent, in the Volga-Ural, Ural-Emba, and northeast Caucasus regions, are presented and discussed. In Devonian rocks, average contents of organic $C$ ranged from 0.25 to 1.97 percent and average contents of minor elements, (in ppm): Sr 220-1,100, Mn 530-3,600, V nd-120, Ni tr-60, Cu 30-140. Ratios of organic $\mathrm{C}$ to $\mathrm{V}, \mathrm{Ni}$, and $\mathrm{Cu}$ suggest that accumulation of these elements is primarily dependent on sorption processes on clay minerals; biogenic processes did not have much influence. Sr:C $C_{\text {organic }}$ ratios show that accumulation of $\mathrm{Sr}$ was directly related to organic $\mathrm{C}$ content. In general, minor element content is related to rock type. A large bibliography is included.-EBT

00190 Katchenkov, S. M. O raspredelenii khimicheskikh elementov $v$ glinakh i glinistykh mineralakh [On the distribution of chemical elements in clays and clay minerals (in Russian)]: Vses. Neft. nauchno-issledov. Geol.-razved. Inst. [Leningrad], Trudy, v. 174 (Geokhim. Sb. 7), p. 98-108, 1961a.

The distribution of elements in clays and clay minerals ( $<1 \mu$ fraction) in sedimentary rocks of the Russian platform and northeast Caucasus and in Recent sediments was studied. Mean contents in some Recent bottom silts are (in ppm): $\mathrm{Sr} 810$, Ba 450, V 136, Cr 84, Mn 820, Ni 85, Cu 35, Zr 100, Be 0.4, organic C 12,500, bitumen 400; in the $<1 \mu$ fraction of Recent sediments, $\mathrm{Sr} 370, \mathrm{Ba} 360, \mathrm{~V} 146, \mathrm{Cr}$ 126, Mn 760, $\mathrm{Ni} 91, \mathrm{Cu} \mathrm{51,} \mathrm{Zr} \mathrm{100,} \mathrm{Be} \mathrm{1,} \mathrm{organic} \mathrm{C} \mathrm{16,500,} \mathrm{bitumen} \mathrm{680;} \mathrm{in} \mathrm{Lower}$ Carboniferous carbonaceous clays of the Tul'ski horizon from Tatar ASSR, Sr 300, $\mathrm{Ba}$ nd, $\mathrm{V}$ nd, $\mathrm{Cr} 20, \mathrm{Mn} \mathrm{300,} \mathrm{Ni}$ tr, $\mathrm{Cu}$ tr, $\mathrm{Zr}$ nd, Be nd, organic C 16,300, bitumen 800. Mobile elements (alkalies, alkaline earths, $\mathrm{Mn}, \mathrm{Cu}, \mathrm{Si}, \mathrm{Fe}$, and others) are removed during chemical weathering and formation of clay minerals in continental environments. During sedimentation and diagenesis, clays are enriched in $\mathrm{Na}, \mathrm{Ca}$, $\mathrm{Sr}, \mathrm{Ba}, \mathrm{Mn}$, and partially $\mathrm{Si}$; clay minerals are enriched in $\mathrm{Al}, \mathrm{Mg}, \mathrm{V}, \mathrm{Cr}, \mathrm{Be}, \mathrm{Ni}$, and sometimes $\mathrm{Fe}$ and $\mathrm{Ti}$.- - EBT.

00191 Katchenkov, S. M. O raspredelenii malykh khimicheskikh elementov v osadochnykh porodakh i neftyakh $v$ svyazi c klimaticheskoy zonal'nost'yu i geokhimicheskoy istoriyey Russkoy platformy [On the distribution of minor chemical elements in sedimentary rocks and petroleums in relation to climatic zones and the geochemical history of the Russian platform (in Russian)]: Vses. Neft. nauchno-issledov. Geol.-razved. Inst. [Leningrad], Trudy, v. 227 (Geokhim. Sb. 9), p. 191-201, 1964.

Siltstones deposited in areas with a warm and humid climate have lower minorelement contents than those deposited in areas with arid or cool and humid climates. Contents of minor elements in clays are related to tectonic processes, climatic environments, and dimensions of basins of sedimentation. Tropical climate in the Volga-Ural region during Early Carboniferous time caused intensive chemical weathering which resulted in increased $\mathrm{V}$ and $\mathrm{Cr}$ and decreased $\mathrm{Sr}, \mathrm{Ba}, \mathrm{Mn}$, and $\mathrm{Cu}$ contents in clays deposited then. Average minor-element contents (from spectrographic analyses) in Devonian clays of the Volga-Ural region are (in ppm): Sr 500, Ba 440, V 120, Cr 108, Mn 490, Ni 66, Cu 78; in Carboniferous clays of the same region, Sr 370, Ba 420, V 135, Cr 108, Mn 220, Ni 68, and Cu 48.-EBT

00192 Katchenkov, S. M.; Flegontova, E. I. Malye khimicheskiye elementy v ilakh Indiiskogo okeana [Minor chemical elements in muds of the Indian Ocean (in Russian)]: Vses. Neft. nauchno-issledov Geol.-razved. Inst. [Leningrad], Trudy, v. 227 , p. $202-211,1964$ b. 
The trace elements in 15 samples of bottom muds and 4 samples of the $<1 \mu$ fraction from the Indian Ocean were determined by spectral methods. Mineralogically the bottom muds and the $<1 \mu$ fraction are mostly hydromica. The $<1 \mu$ fraction was found to contain increased amounts of $\mathrm{Cr}, \mathrm{Ni}$, and $\mathrm{Be}$. An increased content of $\mathrm{V}$ was observed in samples having a large insoluble residue (average $110 \mathrm{ppm} \mathrm{V}$ ). The red mud and mud from Bengal Bay were rich in $\mathrm{Mn}$. The ranges of element contents in all samples are, in ppm (average in parentheses): $\mathrm{Na} 5,000-25,000$ $(15,000)$, Mn $7,000-20,000(16,000)$, Ca $5,000-60,000(33,000)$, Sr tr.-1,000 (550), Ba $300-700(610)$, V tr.-180 (68), Cr 20-160 (84), Ni 20-29, Mn 90-1,300 (680), $\mathrm{Cu}$ (37), Ti (1,600).--Referativnyy Zhur., 1964, abs. 9V37, condensed.

00193 Katchenkov, S. M.; Pesko, Lazer'. Spektral'nyy analiz gornykh porod i bitumov Albanii [Spectral analysis of rocks and bitumens of Albania (in Russian)]: Geologiya Geokhimiya Sb., v. 2, p. 350-359, 1958.

The distribution of elements in diabases, serpentine, chromite, sphalerite, sedimentary rocks of Mesozoic and Tertiary ages, bitumens, and crude oils was investigated. In 2 samples of bituminous shale the following range of contents was found (in ppm): Sr tr. $-4,000$, Ba 1,000-8,400, Ti 2,500-3,000, Mn 38-55, V 4001,500, Cr $30-80, \mathrm{Ni} 100-500, \mathrm{Cu} 30-100, \mathrm{Zr} 50$, and Mo tr.-500.-Referativnyy Zhur., 1959, no. 7 , abs. 13932, condensed.

00215 Katchenkov, S. M.; Flegontova, E. I. Malye elementy v osadochnykh porodakh i neftyakh Zapadnoy Sibiri [Minor elements in sedimentary rocks and petroleums of western Siberia (in Russian)]: Vses. Neft. nauchno-issledov Geol.-razved. Inst. [Leningrad], Trudy, v. 227 (Geokhim. Sb. 9), p. 174-190, 1964a.

Amounts of minor elements in Paleozoic, Jurassic, and Lower Cretaceous deposits were determined by quantitative spectral analysis. Relationships of Mesozoic petroleums and sediments in western Siberia to each other, to older source rocks, and to petroleums of other regions were considered. The ranges of average minorelement contents in bituminous argillites of Early Cretaceous age in western Siberia are (in ppm): Sr 600-3,500, Ba 450-2,100, V 60-700, Cr 80-180, Ni 20-270, Cu $30-270$, Mn 450-1,900, Ti 1,400-3,300, Zr 70-160, and Be 0.75-2.6. The averages of 42 samples of argillites and bitumens of Jurassic age from 9 wells are (number of wells included in the average is in parentheses) (in ppm): $\mathrm{Sr} \mathrm{400,} \mathrm{Ba} \mathrm{600,} \mathrm{V}$ 180 (8) 800 (1), Cr 140, Ni 90 (8) 500 (1), Cu 80 (8) 320 (1), Mn 220 (8) 2,300 (1), $\mathrm{Ti} 2,400$ (7) $4,000(2), \mathrm{Zr} 150$, and $\mathrm{Be} 1.2$. The high contents are in samples from the Dem'cansk region.-EBT

00216 Kato, Iwao; Abe, Masahiro. Minor and trace elements of the core samples from the Kayo exploratory well, R 113, Yabase oil field, Akita Prefecture [in English]: Tohoku Univ. Sci. Repts., 3d ser., v. 6, no. 2, p. 185-192, 1959.

The core samples analyzed by a semiquantitative spectrographic method are mostly of clastic and pyroclastic sediments taken from the Koya $R 113$ well in the Yabase field ranging in depth from $1,693.5$ to $3,112.6 \mathrm{~m}$. These sediments are probably mostly from the Onnagawa (Neogene), the source rock of the petroleum in the Akita oil fields, which is lithologically composed of hard bituminous siltstone. $\mathrm{Ag}, \mathrm{Ba}$, $\mathrm{Co}, \mathrm{Cr}, \mathrm{Cu}, \mathrm{Li}, \mathrm{Mn}, \mathrm{Mo}, \mathrm{Ni}, \mathrm{Pb}, \mathrm{Sn}, \mathrm{Sr}, \mathrm{Ti}, \mathrm{V}$, and $\mathrm{Zn}$ were detected. The section may be separated into several zones on the basis of concentrations and combinations of $\mathrm{Ag}, \mathrm{Co}, \mathrm{Cr}, \mathrm{Mn}, \mathrm{Ni}, \mathrm{Sr}, \mathrm{Zn}$ and, partly, $\mathrm{Ni}$ and $\mathrm{V}$, which are related to other physical properties of the core samples.-Authors' abs., condensed.

00217 Kautzsch, Eberhard. Untersuchungsergebnisse uber die Metallverteilung im Kupferschiefer [Results of investigation on the metal distribution in the Kupferschiefer (in German)]: Arkiv Lagerstättenf., no. 74, 42 p., 1942.

The distribution of $\mathrm{Cu}, \mathrm{Pb}$, and $\mathrm{Zn}$ in the Permian Kupferschiefer of Germany is shown on maps compiled from drill hole and mining information. Reserves of more than 1 million tons of economically minable $\mathrm{Cu}$ are calculated for the several areas considered. Evidence is discussed pertaining to the origin and facies relations of the metal-bearing strata. The author believes that $\mathrm{Cu}$ was derived from the land area adjacent to the Kupferschiefer sea and transported to the sea in dilute solutions.-EBT 
Keith, M. L. See Degens, E. T. 00048

Keith, M. L. See Degens, E. T. 00083

00194 Keith, M. L.; Degens, E. T. Geochemical indicators of marine and fresh-water sediments, in Abelson, P. H., ed., Researches in geochemistry: New York, John Wiley and Sons, Inc., p. 38-61, 1959.

Preliminary geochemical studies of unseparated Pennsylvanian shale samples from the Appalachian coal basin showed $\mathrm{B}$ and $\mathrm{Li}$ appreciably higher and $\mathrm{F}$ and $\mathrm{Sr}$ slightly higher in marine shales; $\mathrm{Ga}$ and $\mathrm{Cr}$ are more abundant in fresh-water shales. The most promising indicator elements are from the marine chemofacies such as $\mathrm{B}, \mathrm{Li}$, $S$, and F. Generally for environmental studies chemical analyses of total sample are much less significant than analyses of separated fractions, because similar materials should be compared. Suggested relative concentrations of $\mathrm{Cu}, \mathrm{Pb}$, and $\mathrm{Sn}$ occur in the organic fraction of fresh-water shales and of $\mathrm{Ni}$ and possibly $\mathrm{V}$ in the organic fraction of marine shales. Average minor-element content of 15 marine shales is (in ppm; standard deviation in parentheses): $\mathrm{Ba} 115$ (34), Ga 8 (7), Li 159 (26), F 817 (182), Sr 250 (52), Cr 62; of 15 fresh-water shales: Ba 44 (28), Ga 17 (4), Li 92 (24), F 642 (121), Sr 205 (52), and Cr 1 I0.-EBT

Keller, W. D. See Muilenburg, G. A. 00151

00195 Kepferle, R. C. Uranium in Sharon Springs Member of Pierre Shale, South Dakota and northeastern Nebraska: U.S. Geol. Survey Bull. 1046-R, p. 577-604, 1959.

The U content of the Sharon Springs Member of the Pierre Shale in South Dakota and northeastern Nebraska was studied in 1954. More than 300 samples of this black organic marine shale of Late Cretaceous age have an average $U$ content of about $15 \mathrm{ppm}$. The most uraniferous parts are about $3 \mathrm{in}$. thick and contain as much as $250 \mathrm{ppm} U$. Semiquantitative spectrographic analyses of 82 samples indicate that $\mathrm{Mo}, \mathrm{Fe}$, and $\mathrm{P}$ contents tend to vary directly with the $\mathrm{U}$ content, whereas $\mathrm{Al}, \mathrm{Ga}, \mathrm{B}, \mathrm{Ti}, \mathrm{Mg}$, and $\mathrm{Na}$ contents vary inversely. Elements found in a few samples are $\mathrm{Be}, \mathrm{Nb}$, and $\mathrm{Ag}$. The concentration of $\mathrm{Cu}$ and $\mathrm{V}$ in the Sharon Springs is notably higher than in other shales. The maximum ranges of minor element contents are (in ppm): U 5-200, B 20-500, Ba 200-5,000, Co 1-50, Cr $5-1,000, \mathrm{Cu} 10-500, \mathrm{Ga} 1-20, \mathrm{Mg} 1,000-10,000$, Mn 10-500, Mo 0.5-200, Ni 5200 , Pb $5-50$, Sc $2-50$, Sr $20-2,000$, V $100-2,000$, Y $0.2-500$, Yb $0.2-50$, Zr 20 200.-Author's abs., modified.

00196 Ketner, K. B.; Smith, J. F., Jr. Composition and origin of siliceous mudstones of the Carlin and Pine Valley quadrangles, Nevada, in Short papers in geology and hydrology: U.S. Geol. Survey Prof. Paper 475-B, p. B45-B47, 1963.

Ordovician, Silurian, and Devonian rocks in the upper plate of the Roberts Mountains thrust fault and the post-thrust Lower Mississippian rocks are generally dark-brown or dark-gray to black siliceous mudstones which have common features regardless of age. They contain from 0.15 to 5.12 percent $C$ and from 63 to 94 percent $\mathrm{SiO}_{2}$, probably as a chemical precipitate. Semiquantitative spectrographic analyses show the following minor element contents in the mudstones (ranges in ppm): 6 Ordovician samples, B 20-70, Ba 70-10,000, Cr 15-100, Cu 50-150, Ga $0-15$, La 0 , Mo $0-7$, Ni 7-50, Pb 0-15, Sc $0-10$, Sr 20-500, V 100-200, Y $10-$ $30, \mathrm{Yb} 1.5-3, \mathrm{Zr} 10-150$; 1 Silurian sample, B 50, Ba 700, Cr 30, Cu 10, Ga 10, $\mathrm{La} 0$, Mo 0 , Ni 5 , Pb 15, Sc 0 , Sr 30, V 150, Y 15, Yb 2, $\mathrm{Zr} 200 ; 4$ Devonian samples, B 30-150, Ba 1,500-3,000, Cr 15-70, Cu 50-100, Ga 0-15, La 0-50, Mo $0-150$, Ni 15-70, Pb 0-15, Sc 0-10, Sr 30-200, V 50-700, Y 0-20, Yb 0-3, Zr 0 $70 ; 5$ Mississippian samples, unit A, B 50-150, Ba 2,000-15,000, $\mathrm{Cr} 50, \mathrm{Cu} 30_{-}$ 100 , Ga $0-15$, La 0, Mo 0-15, Ni 10-70, Pb 0-15, Sc 0-15, Sr 50-150, V 150700 , Y 0-15, Yb 0-2, Zr 20-100; 2 Mississippian samples, unit B, B 50-70, Ba 1,5002,000 , Cr 100, Cu 70, Ga 20-30, La 0-50, Mo 10, Ni 70, Pb 15-20, Sc 15-20, Sr 150, V 200, Y 30, Yb 3, Zr 150-200.-EBT

Khamrabayev, I. Kh. See Gamaleyev, I. E. 00125 
00213 King, W. H.; Wilson, S. R. Diamond drill and auger sampling of vanadiferous shale, Mercur Dome mine, Tooele County, Utah: U.S. Bur. Mines Rept. Inv. 4572, 8 p., 1949.

Results of a U.S. Bureau of Mines development program for vanadiferous carbonaceous shale in the Madison Limestone [Deseret Limestone] of Mississippian age near Mercur, Utah, are outlined. Assay determinations of channel samples from this shale show that $\mathrm{V}_{2} \mathrm{O}_{5}$ content ranges from 0.06 to 0.82 percent. Samples from drill cores showed 0.07 to 0.39 percent $\mathrm{V}_{2} \mathrm{O}_{5}$. The $\mathrm{V}$ is present in the shale in an unidentified form.-EBT

00214 Kita-Badak, M.; Badak, J.; Sałdan, M. Remarks on the occurrence and origin of the uranium-bearing shales of the Menilite Series in the Middle Carpathians [in English]: Acad. Polonaise Sci. Bull,, sér. sci. géol. et géog., v. 12, no. 2, p. 71$77,1964$.

The uranium-bearing shales usually occur in the lower part of the Menilite Series of Eocene age in the Carpathian Flysch. These black oil shales have slaty or leaflike cleavage, range in thickness from 0.5 to $5.0 \mathrm{~m}$, and probably form lenses several kilometers long. $U$ content is as much as $620 \mathrm{ppm}$ and bitumen content usually exceeds 4 percent. In these shales, the $U$ is finely dispersed and related to the existing bituminous material. The concentrations of $U$ are probably of syngenetic origin and due to adsorption by plankton and other organic substances. In the surrounding rocks $U$ content is much lower and is about $12 \mathrm{ppm}$ in most of the shales of the series.-EBT

00205 Klemic, Harry. Uranium occurrences in sedimentary rocks of Pennsylvania: U.S. Geol. Survey Bull. 1107-D, p. 243-288, 1962.

In Pennsylvania, $U$ deposits occur in sedimentary rocks ranging in age from Late Devonian to Late Triassic in the Appalachian Plateaus, Ridge and Valley, and Piedmont provinces. Results of semiquantitative spectrographic analyses of 2 samples of uraniferous black argillite of the Triassic Lockatong Formation compared with analyses of Devonian black shale samples from West Virginia and Tennessee are, in percent $(X=1-9)$ : Lockatong Formation, $\mathrm{Ti}, 0 . \mathrm{X} ; \mathrm{Ba}, \mathrm{Mn}, \mathrm{Sr}, \mathrm{B}, \mathrm{Cr}$, $\mathrm{Co}, \mathrm{Ni}, \mathrm{Cu}, 0.0 \mathrm{X} ; \mathrm{Cu}, \mathrm{Ga}, \mathrm{La}, \mathrm{Y}, \mathrm{Zn}, \mathrm{Zr}, \mathrm{Pb}, \mathrm{V}, \mathrm{Sc}, 0.00 \mathrm{X} ; \mathrm{Yb}, \mathrm{Be}, \mathrm{Ag}, 0.000 \mathrm{X}$; U 0.030, 0.001: 1 sample black shale from West Virginia, $\mathrm{K}, \mathrm{Mg}, \mathrm{Ca}, \mathrm{Na}, 0 . \mathrm{X}$; $\mathrm{Ti}, \mathrm{Ba}, \mathrm{Zn}, \mathrm{V}, \mathrm{Ni}, \mathrm{Mn}, \mathrm{B}, \mathrm{Mo}, \mathrm{Co}, \mathrm{Cu}, 0.0 \mathrm{X}$; Sr, Cr, Y, Pb, Ga, Zr, Sc, 0.00X; Yb, 0.000X; Be 0.0000X; U 0.004: 3 samples black shale from Tennessee, $\mathrm{Ca}$, Na, $\mathrm{Mg}, \mathrm{Ti}, \mathrm{O} . \mathrm{X}$; Ba, Ni, Co, B, Mo, V, Zn, Cr, Cu, Mn, Sr, 0.0X; Sr, Zr, Y, Ga, $\mathrm{Sn}, \mathrm{Pb}, \mathrm{Sc}, 0.00 \mathrm{X} ; \mathrm{Yb}, \mathrm{Be}, 0.000 \mathrm{X}$ - - EBT

00197 Knight, C. L. Ore genesis-the source bed concept: Econ. Geology, v. 52, no. 7, p. $808-817,1957$.

The source bed concept, as proposed, is that sulfide orebodies in the majority of mining fields are, or were derived from, sulfide accumulations deposited contemporaneously with the other sedimentary components at one particular horizon in the sedimentary basin constituting the field, and that the sulfides subsequently migrated in varying degree under the influence of rise in temperature of the rock environment from deep burial or granite intrusion. Bedded deposits are discussed, including the Northern Rhodesia Copper Belt; Belgian Congo; Kupferschiefer; Upper Silesia Lead-Zinc Field, Poland; Maubach-Mechernich Lead-Zinc Field, Germany; Northern Morocco Lead-Zinc Field; Mount Isa and Broken Hill, Australia; Tri-State Zinc-Lead Field; Witwatersrand Gold Field; and others.-Author's abs., modified.

00212 Knitzschke, Gerhard. Vererzung, Hauptmetalle und Spurenelemente des Kupferschiefers in der Sangerhäuser und Mansfelder Mulde [Mineralization, major metals and trace elements of the Kupferschiefer in the Sangerhausen and Mansfeld basins (in German: English summ.)]: Zeitschr. angew. Geologie, v. 7, no. 7, p. 349-356, 1961.

Characteristic differences exist between mineralization of the Sangerhausen trough and the Mansfeld trough. In the ores from Niederröblingen, Sangerhausen, the 
ratio of chalcocite to variegated copper pyrites increases and the contents of pyrites, galena, and zinc blende decrease. Kupferschiefer samples from the Sangerhausen region showed the following range in composition (in percent): $\mathrm{SiO}_{2} 29.92-50.01$, $\mathrm{Fe} 1.87-3.94, \mathrm{Al}_{2} \mathrm{O}_{3}$ 12.24-20.92, $\mathrm{CaO} 3.09-16.31, \mathrm{MgO} 1.74-7.48, \mathrm{CO}_{2}$ 1.25-16.82, C 1.25-14.78; (in ppm): Cu 300-94,800, Pb 100-9,200, Zn 100-13,600, Ag 10-1,220, Co 20-410, Ni 13-230, Ge 5.3-15.8, Se 10-200, Re 23-1,500, V 50-2,250, Mo 60735; from the Mansfeld region (in percent): $\mathrm{SiO}_{2} 26.43-40.62, \mathrm{Fe} 1.73-3.49, \mathrm{Al}_{2} \mathrm{O}_{3}$ 11.25-16.82, $\mathrm{CaO} 5.71-19.12, \mathrm{MgO} 2.50-8.99, \mathrm{CO}_{2} 5.04-20.50, \mathrm{C} 1.54-12.91$, (in ppm): Cu 300-52,800, Pb 500-20,400, Zn 200-48,700, Ag 10-340, Co 20-290, Ni 13-270, Ge 6.4-16.2, Se 10-400, Re 23-235, V 50-1,700, and Mo 65-915.-Author's abs., modified.

00198 Koblic, Josef. Břidlice osecko-kváňské, jejich složení a upotřebení jakož škodlivé účinky vod $\mathrm{z}$ nich vyvěrajících [Osek-kvan shales, their composition and utilization, together with the noxious effects of waters rising from them (in Czech; English summ.)]: Czechoslovakia Státního Geol. Ustavu Vestník, v. 24, no. 4, p. 206-218, 1949.

Analyses of the Osek-Kván Shales (Dobrotivá Division, Ordovician age) in the roof of the diabase tuffs in the Śárka show 12.589 percent $\mathrm{Fe}, 0.303$ percent $\mathrm{P}_{2} \mathrm{O}_{5}, 0.001$ percent $\mathrm{TiO}_{2}, 0.008$ percent $\mathrm{V}_{2} \mathrm{O}_{5}$, and 0.003 percent $\mathrm{NiO}$. $\mathrm{C}(0.948$ percent $)$ gives the shales their dark color.-EBT

00405 Kochenov, A. V.; Baturin, G. N.; Kovaleva, S. A.; Emel'yanov, E. M.; Shimkus, K. M. Uran i organicheskoye veshchestvo $v$ osadkakh Chernogo i Sredizemnogo morey [Uranium and organic matter in sediments of the Black and Mediterranean Seas (in Russian; English abs.)]: Geokhimiya, no. 3, p. 302-313, 1965; English abs., Geochemistry Internat., v. 2, no. 2, p. 212, 1966.

In Black Sea sediments $U$ content ranges from 1 to $15 \mathrm{ppm}$ and organic $\mathrm{C}$ from less than $I$ to about 4.5 percent. In Mediterranean sediments $U$ content ranges from 0.2 to $10 \mathrm{ppm}$ and organic $C$ content is generally less than 1 percent. Correlation between $U$ and organic $C$ is generally stronger in samples from the Black Sea than in samples from the Mediterranean. $U$ is absorbed by organic $C$ in the reducing environment of the Black Sea. In 3 samples selected for detailed study, organic $\mathrm{C}$ content of the initial samples ranged from 2.3 to 4.0 percent, and $\mathrm{U}$ from 12 to $15 \mathrm{ppm}$.-EBT

00182 Koczy, F. F. Thorium in sea water and marine sediments (in English): Geol. Fören. Stockholm Förh., v. 71, no. 2, p. 238-242, 1949a.

The Th content of a few samples of marine sediments have been measured. They contain about $0.1 \mathrm{ppm} \mathrm{Th}$. The geochemistry of $\mathrm{Th}$ and $\mathrm{U}$ in sea water is briefly discussed.-Author's summ., condensed.

00211 Koczy, F. F.; Antal, P. S.; Joensuu, Oiva. Die natürlichen radioaktiven Elemente in Sedimenten [The natural radioactive elements in sediments (in German; English abs.)]: Fortschr. Geologie Rheinland u. Westfalen, v. 10, p. 201-214, 1963.

Distribution of natural radionuclides in the hydrosphere and in sediments is discussed and a summary of analyses presented. By a method of specific chemical fractionation it was shown that $U$ is contained equally in all fractions except in stable clays and resistates. Th shows a contrary chemical behavior. The chemistry of the transporting water markedly affects the distribution of $\mathrm{U}$; that is, in an oxidizing environment $\mathbf{U}$ is dissolved, but in a reducing environment it becomes insoluble. U moves with the ground water level and is affected by organic content, whereas $T h$ is enriched by weathering processes. Th: $U$ ratios cannot be used as indicators for marine or nonmarine origin of sediments, but mineralogical analyses of $U$ minerals may indicate origin. $U$ content in shelf sediments ranges from 3 to $60 \mathrm{ppm}$. In deep sea clays Th content ranges from 4 to $150 \mathrm{ppm}$ and $U$ content from 0.5 to $30 \mathrm{ppm}$. Authors' abs., condensed.

00406 Koczy, F. F. The thorium content of the Cambrian alum shales of Sweden (in English): Sveriges Geol. Undersökn., Ser. C, n:o 509, Årsb. 43, no. 7, 12 p., 1949b. 
The Th content of the Swedish alum shales was determined and found to range from 0.6 to $2 \mathrm{ppm}$. U content ranges from 10 to $200 \mathrm{ppm}$. The Dictyonema shales contain the highest amount of $U$, but the lowest amount of Th. Th seems to have a direct relationship with the clay contents and an indirect relationship with the kerogen contents. $\mathrm{U}$ is more directly related to the kerogen contents. Th in solution seems to be precipitated by sea water very quickly, or if it is transported as a compound by heavy minerals, it settles near river mouths. The alum shales were probably deposited very slowly in a closed marine basin; therefore, Th is likely to be found in small amounts only.--EBT

00198 Konstantynowicz, E. Zechstein mineralization in the outer Sudetic syncline (Lower Silesia) (in English): Acad. Polonaise Sci., sér. sci. géol. et géog., v. 12, no. 1, p. 63-66, 1964.

In 1 to $3 \mathrm{~m}$ of bituminous marly and marly-calcareous sediments of the Lower Zechstein [Upper Permian Kupferschiefer] chalcocite content decreases with depth of burial, whereas bornite, chalcopyrite and pyrite contents increase. Minor quantities of As, Co, Ni, Mo, V, Ga, Sn, and $\mathrm{Cr}_{r}$ occur. $\mathrm{Zn}$ content ranges from 0.2 to 0.28 percent; $\mathrm{Pb}$ content, from an average of 0.03 percent in the copperbearing marl to 1 percent in the lead-bearing marl. In more calcareous strata $\mathrm{Pb}$ content decreases, especially in the bottom and middle sections. The near-shore sediments are less rich in $\mathrm{Cu}$ due to the oxidizing depositional environment. Zones farther from shore have the highest ore accumulation as a result of intensive precipitation of sulfides in a reducing environment; at greater distances from shore the metal content decreases again. A distinct correlation between $\mathrm{Cu}$ and organic C exists.-EBT

00203 Kontorovich, A. E. Khimicheskiy sostav osadochnykh Zapadno-Sibirskoy plity [Chemical composition of sedimentary rocks of the West Siberian block]: Akad. Nauk SSSR Doklady, v. 163, no. 4, p. 984-987, 1965; English translation: Acad. Sci. USSR Doklady, Earth Sci. Sec., Am. Geol. Inst., v. 163, no. 1/6, p. 194-196.

Average concentration of individual elements in Mesozoic and Cenozoic sedimentary rocks of the West Siberian plain was calculated from more than 8,000 analyses. Normal distribution in sandstone, siltstone, and mudstone was applicable to $\mathrm{Si}, \mathrm{Al}$, $\mathrm{Fe}$, and $\mathrm{Mg}$; $\log$-normal distribution was applicable to $\mathrm{V}, \mathrm{Cr}, \mathrm{Ni}, \mathrm{Ti}, \mathrm{Co}, \mathrm{Mn}, \mathrm{Li}$, $\mathrm{S}$, and organic $\mathrm{C}$. Average composition of clay and mudstone of the West Siberian Plain is (in percent; number of analyses in parentheses): $\mathrm{Li} 0.005$ (123), organic C $1.71(4,904), \mathrm{Na} 1.56(256), \mathrm{Mg} 1.10(835), \mathrm{Al} 8.37$ (443), Si 28.63 (945), S 0.51 $(1,286), \mathrm{K} 1.82(257), \mathrm{Ca} 0.72(975)$, Ti $0.46(1,222), \mathrm{V} 0.0092(881), \mathrm{Cr} 0.0083(894)$, Mn 0.049 (808), Fe $4.80(1,272)$, Co $0.0017(920)$, and Ni 0.006 (836). Marine sediments of Late Jurassic age contained maximum amounts of organic C (4.79 percent). Contents of Jurassic clay and mudstone are (weighted mean in percent): Si 27.4, Al 8.8, Fe 4.2, Ti 0.41, Ca 1.0, K 1.7, Na 1.35, Co 0.0019, Ni 0.0076.EBT

00199 Koritnig, Sigmund. Zur Geochemie des Fluors in den Sedimenten [The geochemistry of fluorine in sediments (in German; English abs.)]: Fortschr. Geologie Rheinland u. Westfalen, v. 10, p. 231-238, 1963.

$\mathrm{F}$ is the most abundant halogen in sedimentary rocks. Due to its ionic radius it is especially liable to be camouflaged in $\mathrm{OH}$-bearing minerals. In clays approximately 80 to 90 percent of the $F$ is contained in muscovite, illite, and related minerals of the mica group; the rest is in montmorillonite, kaolinite, and apatite. The average $F$ content of sedimentary micas and illites is about half as large as that of igneous rocks, while montmorillonite and kaolinite contain only the tenth part of $F$ occurring in sedimentary micas. The average $F$ content of deposits of marine origin should be higher than that in deposits of other origins, but other factors mask this so that $F$ content gives no indication of marine or nonmarine origin. In Lias clay, Dobbertin, the total F content is 760 ppm.-Author's abs., condensed.

00204 Koritnig, Sigmund. Ein Beitrage zur Geochemie des Fluor [A contribution to the geochemistry of fluorine (in German; English abs.)]: Geochim. et Cosmochim. Acta, v. 1, p. 89-116, 1951. 
The $\mathrm{F}$ and $\mathrm{P}_{2} \mathrm{O}_{5}$ contents were determined in more than 100 samples of magmatic and sedimentary rocks (single and composite samples). In numerous computations the $F$ was allotted to the minerals in the rocks in order to recognize patterns of distribution and migration. The average $F$ contents of eruptive $(700 \mathrm{ppm})$ and sedimentary $(650 \mathrm{ppm})$ rocks and the upper lithosphere are calculated and an attempt is made to draft the $F$ metabolism and circulation in the earth. Contents of $F$ and $\mathrm{P}_{2} \mathrm{O}_{5}$ in shales and clays (selected from table 3 ) are (in ppm): Kulmtonschiefer, Silesia, $500 \mathrm{~F}, 1,400 \quad \mathrm{P}_{2} \mathrm{O}_{5}$; Wissenbacher shale, $\mathrm{Hartz}, 960 \mathrm{~F}, 1,230 \quad \mathrm{P}_{2} \mathrm{O}_{5}$; Dachschiefer, Rothaargebirge, $310 \mathrm{~F}, 380 \mathrm{P}_{2} \mathrm{O}_{5} ; \mathrm{K}$ upferschiefer, very bituminous, Albungen, $650 \mathrm{~F}, 1,450 \quad \mathrm{P}_{2} \mathrm{O}_{5}$; clay, Lias $\epsilon$, Mecklenburg, $760 \mathrm{~F}, 1,270 \quad \mathrm{P}_{2} \mathrm{O}_{5}$; Posidonenschiefer, Reutlingen, $210 \mathrm{~F}, 370 \mathrm{P}_{2} \mathrm{O}_{5}$.-Author's abs., modified.

Korner, D. See Heide, F. 00404

00209 Korolev, D. F. Nekotorye osobennosti raspredeleniya molibdena v porodakh Bylymskogo ugol'nogo mestorozhdeniya (severnyy Kavkaz) [Some peculiarities of molybdenum distribution in rocks of the Bylymsk coal deposits (northern Caucasus)]: Geokhimiya, no. 5, p. 420-424, 1957; English translation: Geochemistry, no. 5, p. 493-499, 1957 [1960].

The Bylymsk coal deposit is within the boundaries of Kabardin ASSR, $12 \mathrm{~km}$ north of the town of Tyrny-Auz. The coal-bearing series, ranging in thickness from 30 to $40 \mathrm{~m}$, is composed of interbedded coal and clayey shales containing siderite concretions. The series transgressively overlies Precambrian crystalline schists and in age is related to the Toar stage of the late Liassic. Mo content of the rocks ranges from 0 to $3 \mathrm{ppm}$; it averages $0.8 \mathrm{ppm}$ in the siderites and $0.6 \mathrm{ppm}$ in the carbonaceous shales. Unaltered carbonaceous shale from mine workings averages $1.3 \mathrm{ppm} \mathrm{Mo}$; the range of Mo content of both the unaltered and of the weathered shale samples is 0 to $2 \mathrm{ppm}$. Mo accumulation is related to the intensity of reduction processes.-EBT

\section{Kovaleva, S. A. See Kochenov, A. V. 00405}

00206 Krauskopf, K. B. Factors controlling the concentrations of thirteen rare metals in sea-water: Geochim. et Cosmochim. Acta, v. 9, p. 1-32b, 1956.

Rare metals are notably concentrated in certain marine sedimentary rocks, especially black shales and phosphorites. The source of the metals is commonly thought to be sea-water; factors controlling the concentration of 13 metals $(\mathrm{Zn}, \mathrm{Cu}, \mathrm{Pb}, \mathrm{Bi}$, $\mathrm{Cd}, \mathrm{Ni}, \mathrm{Co}, \mathrm{Hg}, \mathrm{Ag}, \mathrm{Cr}, \mathrm{Mo}, \mathrm{W}$, and $\mathrm{V}$ ) were studied. Sea-water is greatly undersaturated in all 13 metals. Local precipitation of sulfides is possible for $\mathrm{Cu}$, $\mathrm{Zn}, \mathrm{Hg}, \mathrm{Ag}, \mathrm{Cd}, \mathrm{Bi}$, and $\mathrm{Pb}$, but is probably not their chief control. Adsorption is a possible mechanism for all elements except $\mathrm{V}, \mathrm{W}, \mathrm{Ni}, \mathrm{Co}$, and $\mathrm{Cr}$ : adsorption processes supplemented by organic reaction qualitatively explain the distribution of rare metals. $\mathrm{V}, \mathrm{Ni}, \mathrm{Co}$, and $\mathrm{Mo}$, four metals most characteristic of black shales and asphalts, belong to a group which, according to experiments, cannot be controlled by precipitation of sulfides; biologic processes must be important in the enrichment of them in sedimentary rocks.-EBT

00210 Krauskopf, K. B. Sedimentary deposits of rare metals, in pt. 1 of Bateman, A. M., ed., Economic geology, 50th anniversary volume, 1905-1955: Urbana, Ill., Econ. Geology Pub. Co., p. 411-463, 1955.

Detailed comparison of published analyses of sedimentary rocks for rare metals (excluding radioactive metals) suggests that nearly all minor metals are more concentrated in shales, although seldom more than twice the crustal abundances in ordinary shales. Rare metals are most enriched in organic sediments: enrichments of more than 1,000 times the crustal abundances are reported for several elements. Coal is characterized by enrichment in Ge, black shales and petroleum by $\mathrm{V}$. Processes of enrichment are mechanical concentration, chemical precipitation, adsorption, and organic processes; adsorption and organic processes are more important. Widespread enrichment occurs in coal swamps, shallow marine sediments, stagnant bottoms and open shelves in areas of upwelling water, and semiarid slopes and basins where red sandstones and conglomerates are deposited. Local conditions may cause concentrations in other environments. Concentrations of 
minor elements in black shales are (averages; maximums in parentheses; in ppm): Ag 5-50 (800), As 75-225 (825?), Au 0.01-1? (7), Ba 450-700? (2,400?), Be 1? (4?), Bi (100?), Cd (300?), Co 5-50 (180), Cr 10-500 (5,000), Cu 20-300 (1000), Ga 70 ? (170?), Ge 7?, In (0.2?), Li 17? (660?), Mo 10-300 (1,000), Nb 0.6?, Ni 20-300 $(2,400)$, $\mathrm{Pb} 20-400$ ? (700), Pt metals (6?), Rb 450?, rare earth metals 25-100?, Sb (300?), Sc 16?, Sn (260?), Sr 25-400? (2,000?), Tl 1? (3?), V 50-2,000 (14,000), Zn 100$1000(10,000)$, and $Z_{r} 10-20$. Enrichment factors are (averages; maximums in parentheses): Ag 50-500 (8,000), As 15-45? (165?), Au 2-200? (1,400), Ba 2-5? (10?), $\mathrm{Be}<0.5$ ? (2?), Bi (500?), Cd (2,000?), Co 0.2-2 (8), Cr 0.05-2.5 (25), Cu 0.3-4 (14), Ga 5? (12?), Ge 1?, In (2?), Li 0.3? (10?), Mo $10-300(1,000)$, Nb 0.03?, Ni 0.24 (30), Pb 1.2-25? (44), Pt metals (300?), Rb 1.5?, rare earth metals 0.2-0.7?, Sb (300?), Sc 3?, Sn (7?), Sr 0.1-1.3? (7?), T1 2? (5?), V 0.3-13 (93), Zn 0.8-8 (77), and Zr 0.05-0.09?.-Author's abs., modified.

Krejci-Graf, K. See Goldschmidt, V. M.00086

Krejci-Graf, K. See Ernst, Werner. 00129

Krejci-Graf, Karl. See Borchert, Herman. 00031

00207 Krejci-Graf, Karl; Wickman, F. E. Ein geochemisches Profil durch den Lias alpha [A geochemical profile through the Lias Alpha (in German; English abs.)]: Geochim. et Cosmochim. Acta, v. 18, p. 259-272, 1960.

A systematic study of trace elements and isotopes in lithological profiles and connected oils might lead to the determination of source rocks; results will be conclusive only after study of the whole stratigraphic sequence has been completed. Oils contain notably less $\mathrm{Cr}$ than the shales nearby; the same relationship is seen between tars ("oils") and their parent oil shales. Drill-core samples of Lias Alpha clay shale from Lower Saxony show the following ranges of $\mathrm{Cr}$, Mo, and $\mathrm{V}$ contents (in ppm): $\mathrm{Cr}_{2} \mathrm{O}_{3}<2-550, \mathrm{MoO}_{3} 2-28$, and $\mathrm{V}_{2} \mathrm{O}_{3} 70-225$. In the Messel oil shale are the following ranges (in ppm): nodular shale: $\mathrm{V}_{2} \mathrm{O}_{3} 100-500, \mathrm{Cr}_{2} \mathrm{O}_{3}, 500-1,000$, $\mathrm{Co}_{3} \mathrm{O}_{4} 50-100$, NiO 500, bitumen 6 percent; foliated shale: $\mathrm{V}_{2} \mathrm{O}_{3} 100-500, \mathrm{Cr}_{2} \mathrm{O}_{3}$ $500-1,000, \mathrm{Co}_{3} \mathrm{O}_{4} 100, \mathrm{NiO} 500-800$; bitumen 7 percent; foliated shale: $\mathrm{V}_{2} \mathrm{O}_{3} 100$ $500, \mathrm{Cr}_{2} \mathrm{O}_{3} 100-500, \mathrm{Co}_{3} \mathrm{O}_{4} 50-100, \mathrm{NiO} 100-500$, bitumen 8 percent; and oil shale: $\mathrm{V}_{2} \mathrm{O}_{3} 450, \mathrm{Cr}_{2} \mathrm{O}_{3} 600, \mathrm{Co}_{3} \mathrm{O}_{4}--, \mathrm{NiO} 650$.- Authors' abs., modified.

00208 Krumbein, W. C.; Slack, H. A. Statistical analysis of low-level radioactivity of Pennsylvanian black fissile shale in Illinois: Geol. Soc. America Bull., v. 67, no. 6, p. 739-762, 1956.

Black fissile shale in Pennsylvanian cyclothems in the western part of the Illinois basin shows low-level radioactivity as measured by alpha-particle emission. Preliminary analysis showed tenfold variability in radioactivity among closely spaced samples, with no apparent concentration in particular zones of the thin shale units. Interlocked regional and local sampling designs of shale in the Brereton Formation furnished data for estimating stratigraphic variability of samples. Neither geological evidence nor statistical analysis suggested any strong regional gradient in radioactivity and both suggest that the radioactive material was associated with depositional environment, rather than diagenetic. A detailed description of statistical methods used is included.-Authors' abs., modified.

Kulp, J. L. See Cobb, J. C. 00054

Kulp, J. L. See Holland, H. D. 00183

Kulp, J. L. See Turekian, K. K.00351

Kunashova, K. G. See Baranov, V. I. 00009

Kurbanova, N. Z. See Sindeeva, N. D. 00302

00200 Kuroda, P. K.; Sandell, E. B. Geochemistry of molybdenum: Geochim. et Cosmochim. Acta, v. 6, p. 35-63, 1954. 
Shales poor in organic matter contain about as much Mo as igneous rocks (average about $1 \mathrm{ppm}$ ). Carbonaceous and pyritic shales are usually much richer in Mo, often containing $100 \mathrm{ppm}$ or more. Carbonate rocks usually contain less than 0.5 ppm except when organic matter is present. Because of the variable amounts of Mo in shales, an average value for sedimentary rocks is difficult to calculate, but may be much higher than for igneous rocks because of Mo in hydrothermal solutions and volcanic emanations. Deep-sea sediments contain little Mo and the few metamorphic rocks studied averaged $0.5 \mathrm{ppm}$ Mo, with no correlation between Mo content and metamorphic grade. In the composite sample of 36 European Paleozoic shales Mo content was $4.5 \mathrm{ppm}$, in the Cason Shale (Ordovician), Arkansas, 2.8; in Tasmanite, Latrobe, Tasmania, 4.6; in organic shale, Katella, Alaska, 9.3; and in vanadiferous shale (Permian), Idaho, 65, 87 ppm. - Authors' abs., modified.

Kuz'mina, L. A. See Baranov, V. I. 00025

Lakin, H. W. See Byers, H. G. 00062

Lakin, H. W. See Byers, H. G. 00063

Lakin, H. W. See Davidson, D. F. 00079

Lakin, H. W. See Davidson, D. F. 00080

Lakin, H. W. See Davidson, D. F. 00081

00179 Lakin, H. W.; Byers, H. G. Selenium occurrence in certain soils in the United States, with a discussion of related topics. Sixth report: U.S. Dept. Agriculture Tech. Bull. 783, 26 p., 1941.

The Se content of most of the samples of Upper Cretaceous shales from California is less than $1 \mathrm{ppm}$. Of 63 shale samples, only 13 contained I ppm or more of $\mathrm{Se}$; only 4 contained more than $15 \mathrm{ppm}$ with the maximum Se content $28 \mathrm{ppm}$. The Moreno Shale of Late Cretaceous age, similar in gross physical appearance to the Pierre Shale of South Dakota, contained 2, 8 , and $28 \mathrm{ppm} \mathrm{Se} \mathrm{in} 3$ samples. Probably the primary source of Se concentration in Upper Cretaceous formations is in contemporaneous volcanic activity. The Eagle Ford Shale of Cretaceous age from Oklahoma shows no marked concentration of Se. A general discussion of the modes of accumulation of Se is presented.-EBT

00201 Lakin, H. W. Geochemistry of selenium in relation to agriculture, in Anderson, M. S., Lakin, H. W., Beeson, K. C., Smith, F. F., and Thacker, Edward, Selenium in agriculture: U.S. Dept. Agriculture, Agr. Handb. 200, p. 3-24, 1961.

Se content in sedimentary rock samples in western United States ranges from less than $0.02 \mathrm{ppm}$ to more than $1,500 \mathrm{ppm}$. Se content varies both vertically and areally. Certain formations, however, contain abnormal amounts of Se ( $>2 \mathrm{ppm})$ throughout, and over large areas. Some zones in the Mississippian Manning Canyon Shale and the Permian Phosphoria Formation contain 100 to 600 times as much $\mathrm{Se}$ as the composite of 36 European Paleozoic shales (Minami, 1935a). High Se content is characteristic of the upper part of the Niobrara Formation and the lower part of the Pierre Shale; an average content of 20 ppm Se occurs above and below the contact of these two Cretaceous formations in North Dakota, Nebraska, and Kansas. Data on Se from the literature are reviewed.-Author's discussion, modified.

00202 Lakin, H. W.; Byers, H. G. Selenium occurrence in certain soils in the United States, with a discussion of related topics. Seventh report: U.S. Dept. Agriculture Tech. Bull. 950, 36 p., 1948.

Results of a survey of Se occurrence in North Dakota and of reconnaissance examination of parts of Oregon, Idaho, Nevada, and Utah where Se poisoning of livestock was reported are presented. Analyses of black shales showed: A sample of dark-grey thin-bedded shale (Benton?) of Late Cretaceous age from North Dakota contained $16 \mathrm{ppm}$ Se. Samples from the upper part of the Niobarra Formation and the lower part of the Pierre Shale of Late Cretaceous age from North 
Dakota contained from 1.4 to $36 \mathrm{ppm}$ Se. In Utah, Se content of samples of the Manning Canyon Shale of Carboniferous [Mississippian] age ranged from 0.4 to $54 \mathrm{ppm}$. EBT

Lakin, H. W. See Williams, K. T.00315

00175 Landergren, Sture; Manheim, F. T. Uber die Abhängigkeit der Verteilung von Schwermetallen von der Fazies [On the relationship of the distribution of trace metals in facies (in German; English abs.)]: Fortschr. Geologie Rheinland u Westfalen, v. 10, p. $173192,1963$.

The analyses, which were mostly done in the geochemical laboratory of the Geological Survey of Sweden, were for major constituents, ferrides (Ti, V, Cr, Mn, Fe, $\mathrm{Co}$, and $\mathrm{Ni}$ ), and other minor elements such as $\mathrm{Cu}, \mathrm{Zn}, \mathrm{Pb}, \mathrm{Mo}, \mathrm{Ga}, \mathrm{Sr}$, and $\mathrm{Ba}$, and in some cases $\mathrm{Th}$ and $\mathrm{U}$. $\mathrm{Sn}$ and $\mathrm{Zr}$ were noted but not estimated quantitatively. Knowledge of the major composition of sediments is essential for proper interpretation of minor and trace element relationships. Distribution patterns of most of the metals included here are affected by factors other than salinity of depositional environment; therefore they are unsuitable for salinity indicators. Ba and $\mathrm{Sr}$ are possible salinity indicators under certain conditions, particularly in carbonate depositional environments, but insufficient data are available to evaluate their potential. To date $\mathbf{B}$ is the only geochemical indicator consistently sensitive to variations in salinity. Minor element contents in some clay sediments are (average in $\mathrm{ppm}$ ): Deep sea clay, 450 samples, $\mathrm{V} 110, \mathrm{Cr} 60, \mathrm{Co} 150, \mathrm{Ni} 210, \mathrm{~B} 135, \mathrm{Ga}$ 20, $\mathrm{Cu} 560, \mathrm{Zn} 85, \mathrm{~Pb} 63, \mathrm{Mo} \mathrm{27,} \mathrm{U} \mathrm{2.6,} \mathrm{Sr} \mathrm{130,} \mathrm{Ba} \mathrm{1,200,} \mathrm{TiO.} \mathrm{7,800,} \mathrm{MnO.}$ 4.800 31.400: Atlantic Ocean deep sea clay, 100 samples, V 120, Cr 50, Co 30, Ni 60, B 130, Ga 24, Cu 98, Zn 130, Pb 35, Mo 4, U 2.6, Sr 110, Ba 380, TiO. 8,600, $\mathrm{MnO}, 4,800$; near shore bottom sediment, Skagerrak Kattegatt, 4 samples, V 110. Cr 90, Co 7, Ni 38, B 115, Ga 18, Cu 20, Zn 59, Pb 33, Mo <3, Th 10, U 6 , $\mathrm{Sr} 240$, Ba 380, TiO, 7,400, $\mathrm{MnO}$. 700; Baltic Sea bottom sediment, 825 samples,

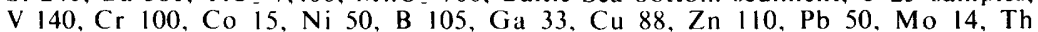
9. U 8, $\mathrm{Sr} 170, \mathrm{Ba} 620, \mathrm{TiO}_{2} 7,900, \mathrm{MnO}_{2} 7,400 ; \mathrm{Kyrkfärden}$ bottom sediment (fjord in Baltic Sea), 26 samples, V 60, Cr 80, Co 12, Ni 36, B 62, Ga 24, Cu 54, Zn 130, Pb 31, Mo 7. Th 12, U 11, Sr 180, Ba 550, TiO. 7,200, MnO2 900; Cambrian and Ordovician alum shale, Sweden, 15450 samples (Assarsson and Grundulis, 1961: Manheim, unpublished; Dahlman, 1962, personal commun.), V 1,500, (irregularly distributed, $1003,600 \mathrm{ppm}$ ), $\mathrm{Cr} 70, \mathrm{Co} 35, \mathrm{Ni} 200$ (irregularly distributed, <30-500), B 145 (southern Sweden), B 106 (central Sweden), Ga 35, $\mathrm{Cu} 170, \mathrm{Zn} 80$ (occasional higher contents, 1,700), Pb 38, Mo 89, Th 7, U 160 (average of 250 analyses, range $50-500$ ), Sr 91, Ba 500, TiO. 7,100, MnO.2 200.Authors" abs., modified.

00176 Landergren, Sture; Joensuu, Oiva. Studies on trace element distribution in a sediment core from the Pacific Ocean: Prog. in Oceanography, v. 3, p. 179-189, 1965.

Main sources of trace elements in the sediment of core no. 69, sta. 102 of the Swedish Deep-Sea Expedition 1947-48, were: Material weathered from basaltic to andesitic rocks-Li, Rb, Sc: Authigenic mineral-forming processes-K, Y, La; Precipitation of colloids due to adsorption of +ions in the sea-the pair of $\mathrm{M} \mathrm{nO}_{2}$ colloids and $\mathrm{Ni}^{2}+$ ions; and Precipitation due to biological processes- $\mathrm{Ba}, \mathrm{Cu}, \mathrm{V}$, and $\mathrm{Mo}$. $\mathrm{Sr}$ content is directly proportional to $\mathrm{CaCO}_{3} ; \mathrm{Ba}$ is completely independent of $\mathrm{CaCO}_{3}$. The upper core is manganiferous-ferruginous clay (red clay 6-322 cm deep); the lower (340-566 cm deep) is manganiferous-marl ooze. The average contents are (in ppm; upper core first): Li 28, 23: K 32,000, 29,000; Rb 74, 67; Be 1.5, 1.3; Sr 288, 559; Ba 495, 325; Sc 22, 14; Y 597, 189; La 283, 100; V 132, 88; Cr 42, 59; Co 217, 86; Ni 405, 200; Ga 8.8, 8.1; Cu 510; 211; Pb 37, 24; Mo 70, 26; $\mathrm{Zr}$ $135,109 .-\mathrm{EBT}$

00177 Landergren, Sture. On the geochemistry of deep-sea sediments: Repts. Swedish Deep-Sea Expedition, 1947-1948, v. 10, Spec. Inv. no. 5, p. 61-154, 1964.

Samples of sediment cores collected from the Pacific Ocean during the Swedish Deep-Sea Expedition 1947-48 and samples from the Atlantic and Indian Oceans and Tyrrhenian Sea have been spectrochemically analyzed for major constituents, 
$B$, and the ferrides. Average contents in 450 samples of pelagic clays are (in ppm): $\mathrm{Ti} 4,200, \mathrm{~V} 110, \mathrm{Cr} 62, \mathrm{Mn}(12,900)$, Fe 51,000, Co 150, Ni 210, and $\mathrm{B}_{2} \mathrm{O}_{3} 460$. Mean content and distribution of major constituents is near that of "average shale."

B content is related to salinity and grain-size and gives an indication of the balance of volatile elements in the sea. Principal source of $\mathrm{Mn}, \mathrm{Co}$, and $\mathrm{Ni}$ is sea water; $\mathrm{Mn}$ is precipitated on the sea floor: then $\mathrm{Co}$ and $\mathrm{Ni}$ are adsorbed on fine-grained manganese oxide (or hydroxide) particles. Variations in amount of $\mathrm{Mn}$ and $\mathrm{Ni}$ may be related to glacial periods: bottom currents also affect their distribution. The geochemistry of B and clay sediments is discussed in detail.-EBT

00178 Landergren, Sture. Contribution to the geochemistry of boron. II. The distribution of boron in some Swedish sediments, rocks, and iron ores. The boron cycle in the upper lithosphere (in English): Arkiv Kemi, Mineralogi, Geologi, v. 19. A. no. 26, 31 p., 1945.

Comparison between B contents of Cambrian alum shales and of clayslates which contain less organic C suggests that very little of the B content of alum shales is in their organic substances. $\mathrm{B}_{2} \mathrm{O}_{3}$ content in Cambrian rocks ranges from 220 to $450 \mathrm{ppm}$; the mean of 359 analyses is $320 \mathrm{ppm}$. B. $\mathrm{O}_{3}$ content in Ordovician rocks ranges from 60 to $580 \mathrm{ppm}$; the mean of 18 analyses is $240 \mathrm{ppm}$. In Silurian rocks $\mathrm{B}_{2} \mathrm{O}$ : content ranges from 130 to $290 \mathrm{ppm}$ : the mean of 4 analyses is $180 \mathrm{ppm}$. A black marine shale (Boserup) in the Lias Stage from northwest Scandia contains $190260 \mathrm{ppm} \quad \mathrm{B}_{-} \mathrm{O}_{3}$. Samples from 3 boreholes were analyzed by a spectrographic method, accurate within \pm 10 percent; those from the deep channel of Koster averaged $450 \mathrm{ppm} \mathrm{B}{ }_{2} \mathrm{O}_{3}$; from Alsbäck, Gullmarsfjord, $320 \mathrm{ppm}$; and from the Gulf of Bothnia off Sundsvall, $100 \mathrm{ppm}$.--EBT

00171 Landin, John. Radium i Sverige [Radium in Sweden (in Swedish)]: Arkiv Kemi, Mineralogi, Geologi, v. 2, no. 1, n:o 2, 7 p., 1905.

Two samples of kolm from the Swedish Alum Shate of Cambrian age were analyzed. Ash content of sample $A$ was 22.28 percent; $\mathrm{U}_{3} \mathrm{O}_{8}$ content in the ash, 2.87 percent. Ash content of sample B was 45.11 percent; $\mathrm{U}_{3} \mathrm{O}_{3}$ content of the ash, 0.92 percent. A sample of the Billinge Shale contained 0.01 percent $\mathrm{Zn}$. The $\mathrm{Ra}$ content of the shales is discussed.-EBT

00172 Landis, E. R. Radioactivity and uranium content, Sharon Springs Member of the Pierre Shale. Kansas and Colorado: U.S. Geol. Survey Bull. 1046-L, p. 299318,1959 .

The Sharon Springs Member of the Cretaceous Pierre Shale and its lateral equivalents are $155-500 \mathrm{ft}$ thick and generally contain about $10 \mathrm{ppm}$ U. Several shale beds or sequences of beds contain $30-60 \mathrm{ppm} U$. No definite distributional pattern of radioactivity and $U$ content is indicated by available data. Element content variations between samples may be due to differences in detrital mineral content. A sample of the Blue Hill Shale Member of the Carlile Shale is similar to the Sharon Springs samples in trace-element composition except that it contains $100-500 \mathrm{ppm} \mathrm{Ce}$, La, and Nd. Semiquantitative spectrographic analyses of 12 Sharon Springs samples show the following maximum ranges (in ppm): $\mathrm{Be}$ 1-5, B $100-500$, Sc 5-50, Ti 1,000-5,000, V 50-500, Cr 10-500, Mn 50-1,000, Co 1050 , Ni 10-500, Cu 10-500, Ga 10-100, Sr 100-i,000, Y 10-50, Zr 10-500, Mo $10-$ 500, Ba 100-5,000, Yb 1-5, Pb 10-50, Se 5-50, As 5-100, and U 5-100.-EBT

00173 Landis, E. R. Uranium and other trace elements in Devonian and Mississippian black shales in the central midcontinent area: U.S. Geol. Survey Bull. 1107-E, p. 289-336, 1962.

The Woodford and Chattanooga Shales and Arkansas Novaculite of Late Devonian and Early Mississippian age, in Kansas, Oklahoma, Arkansas, and Missouri, are partial or total equivalents of each other. U content of samples of the Woodford Shale in Oklahoma ranges from <10 to $140 \mathrm{ppm}$, but modal, median, and arithmetic mean values are only 10,20 , and $30 \mathrm{ppm}$, respectively; phosphatic nodules in the shale contain an average of $60 \mathrm{ppm} \mathrm{U}$. Modal and median values of the Chattannooga Shale are about $20 \mathrm{ppm} \mathrm{U;} \mathrm{U} \mathrm{content} \mathrm{ranges} \mathrm{from}<10$ to $120 \mathrm{ppm}$. $\mathrm{U}$ content in Arkansas Novaculite averages $10 \mathrm{ppm}$ and only 1 sample contained 
$>40 \mathrm{ppm}$. A positive correlation of organic $\mathrm{C}$ content to $\mathrm{U}$ content and of $\mathrm{U}$ content to rare-earth element content is suggested. Semiquantitative spectrographic analyses show the following (ranges in ppm): Woodford Shale, Ti 500-10,000, M n 10-200, Ag 0.5-10, B 100-1,000, Ba 500-5,000, Be 0.5-5, Ce <300-1,000, Co $10-$ $50, \mathrm{Cr} 10-1,000$, Cu $100-1,000$, Ga $20-100$, La $20-50$, Mo $5-200$, Nd $<20-100$, $\mathrm{Ni} 50-500$, Pb 10-200, Sc $10-20$, Sn $<10-20$, Sr $50-500$, V $100-5,000$, Y $20-100$, Yb 2-10, $\mathrm{Zn}<70-500, \mathrm{Zr} 10-100$; Chattanooga Shale, Ti 2,000-5,000, Mn 20-100, $\mathrm{Ag}<0.5-2$, B $200-500$, Ba $500-1,000$, Be 1-2, Ce - , Co $10-200$, Cr $50-100$, Cu $50-200$, Ga $50-100$, La $20-100$, Mo $10-200$, Nd - , Ni 100-500, Pb 10-200, Sc $10-20$, Sn--, Sr $100-500$, V 100-500, Y 20-50, Yb 2-5, Zn $<70-200$, Zr 50-100; Arkansas Novaculite, Ti $2,000-5,000, \mathrm{Mn} 20-50$, Ag --, B 100-500, Ba $500-5,000$, Be 0.5-2, Ce --, Co 10-20, Cr 50-200, Cu 50-500, Ga 20-100, La 20-100, Mo $5-50, \mathrm{Nd}--, \mathrm{Ni} 100-200, \mathrm{~Pb} 10-20$, Sc $10-20$, Sn --, Sr 50-1,000, V 100-500, Y 20-100, Yb 2-10, Zn--, Zr 50-100,-EBT

Landis, E. R. See Swanson, V. E. 00277

00174 Larsson, Alf. [Uranium and radium in kolm (in Swedish)]: Svensk Kem. Tidskr. Stockholm, v. 31, p. 63-70, 1919; English translation through Chem. Club Library.

The geology of kolm from Cambrian alum shales in Sweden, the composition of kolm, and previous analyses are discussed. In kolm 0.47 percent $\mathrm{U}_{3} \mathrm{O}_{8}(1.59$ percent in ash) is found.-EBT

Laub, D. C. See Tschanz, C. M. 00281

00137 Le Riche, H. H. The distribution of certain elements in the Lower Lias of southern England: Geochim. et Cosmochim. Acta, v. 16, p. 101-122, 1959.

Excess Mo, without excess $\mathrm{Cu}$ to act as an antidote, in soil derived from Lower Lias shales in central Somerset causes teart disease in cattle. Analyses have been made of numerous samples of these shales from two boreholes and from outcrops on the coasts of Dorset and Glamorgan. $\mathrm{Mo}, \mathrm{V}, \mathrm{Cu}$, and $\mathrm{Ni}$ contents correlate with organic $\mathrm{C}$ content; these together are related to $\mathrm{CaCO}_{3}$, reaching a maximum with 20-50 percent $\mathrm{CaCO}_{3}$. Detailed study of a shale sample showed that some of the Mo is associated with silicates and pyrite while nearly all $\mathrm{V}$ is in silicates, although organic matter seems directly or indirectly responsible for its accumulation. $\mathrm{Cu}$ and $\mathrm{Ni}$ appear mainly organically bound; some $\mathrm{Ni}$ is in exchangeable form. Trace-element contents in Stowell Peak and Lyme Regis samples are (range in ppm on noncalcareous basis): Mo 3-320, V 77-460, Cu 7-95, Ni 35-360, Co 12-41, and organic $\mathrm{C} 0.87-10.3$ percent.-Author's abs., modified.

00138 Leutwein, Friedrich. Geochemische Untersuchungen an den Alaun- und Kieselschiefern Thüringens [Geochemical investigations of the alum and siliceous shales of Thuringia (in German; English summ.)]: Archiv Lagerstättenf., no. 82, 45 p., 1951a.

The distribution of some rare metals in alum shales and siliceous shales of Late Silurian age in Thuringia is examined. Numerous spectroscopically analyzed samples show that these rocks generally contain about $250 \mathrm{ppm} \mathrm{Mo}, 700 \mathrm{ppm} \mathrm{V}, 30 \mathrm{ppm}$ $\mathrm{Cr}$, and $60 \mathrm{ppm} \mathrm{Ni}$. Au content ranges from 0.0 to $0.2 \mathrm{ppm}$. $\mathrm{Cu}, \mathrm{Zn}, \mathrm{Y}, \mathrm{Pb}$, and $\mathrm{Ga}$ were also found. $\mathrm{V}$ and Mo were precipitated in an anaerobic environment (sapropel facies): calculations show that the metal content of modern sea water and living organisms is sufficient to produce sediments rich in metals. Individual analyses are compared with similar non-Thuringian rocks, especially those from Lusatia, Czechoslovakia, and Westphalia, and similar facies from the north and east. Behavior of trace metals during weathering of rock was studied and the question of economical extraction of $\mathrm{V}$ and Mo from the shales considered.--EBT

00139 Leutwein, Friedrich. Uber das Vorkommen von Gold in Thüringischen Alaunund Kieselschiefern [On the occurrence of gold in Thuringian alum and siliceous shales (in German: as seen in translation by C. L. Sainsbury, 1967, written commun.)]: Hallesches Jahrb. für Mitteldeutsche Erdgeschichte, v. 1, no. 2, p. 82$85,195 \mathrm{lb}$. 


\section{BIBLIOGRAPHY OF MINOR ELEMENTS IN BLACK SHALES}

Gold is recovered as a minor byproduct in the production of alum from siliceous and alum shales of Late Silurian age in Thuringia. The shales are colored dark by carbonaceous matter, contain finely dispersed pyrite, and are weakly metamorphosed. They were probably deposited in a reducing environment. The Au content in 14 samples of alum and siliceous shales ranged from nd to $0.8 \mathrm{ppm}$ and $\mathrm{Ag}$ content from 1 to $30 \mathrm{ppm}$. The $\mathrm{Au}$ is found not in the pyrite, but in the carbonaceous fraction; it is probably bound adsorptively on the C. Samples of modern sapropelic materials from the North Sea and the Baltic Sea were also found to contain $\mathrm{Au}$. North Sea samples from the Norwegian coast contained from 0.7 to $2.5 \mathrm{ppm} \mathrm{Au}$; Baltic Sea samples contained 0.5 to $0.7 \mathrm{ppm} \mathrm{Au}$.-EBT

00169 Leutwein, Friedrich. Das Vorkommen von Spurenmetallen in organogenen Sedimenten [The occurrence of trace metals in organic sediments (in German; Russian abs.)]: Acta Geol., v. 1, no. 1-4, p. 143-157, 1952.

Chemical and spectrographic analyses of bituminous and coaly rocks ranging in age from Silurian to Tertiary are reported. $\mathrm{Zn}, \mathrm{Cu}$, and $\mathrm{Ni}$ are bound with the iron sulfides. Au is adsorbed on coaly substances; $\mathrm{V}$ and Mo are bound with organic matter. Samples of sediments from the North and Baltic Seas showed the following ranges in organic $\mathrm{C}$ content (in percent) and trace elements (in ppm): organic $\mathrm{C}$ nd-5.9, V 20-100, Mo tr-40, Cu 30-60, Ni 10-100, Au 0.5-2.5 (7 samples). Samples of black clay shale from a profile of the Alaunschiefer in Arnsberg, Westfalen, showed the following range in trace-metal content (in ppm): $\mathrm{Mn} 200->1,000, \mathrm{Ni}$ $200-700, \mathrm{Cu} 10-50$, V 40-150, Mo nd -20 , Cr 40-90 (9 samples). The black and gray flysch sediments of Gault in Bayern contained on the average $30-50 \mathrm{ppm} \mathrm{V}$, 50-80 ppm Ni, and about $10 \mathrm{ppm} \mathrm{Mo--EBT}$

00170 Leutwein, Friedrich; Starke, Rainer. Über die Möglichkeit der geochemischen Prospektion auf Selen, untersucht am Beispiel des Kupferschiefers und des Tilkeröder Erzbezirks [On the possibility of geochemical prospecting for selenium, the Kupferschiefers and the Tilkeroder ore district as investigated examples (in German)]: Geologie, v. 6, no. 4, p. 349-378, 1957.

The usefulness of geochemical prospecting for Se and Se minerals in the East Harz was tested. Se is very mobile in shales. In various samples of the Kupferschiefer beds $S e$ content ranged from 0.51 to $15 \mathrm{ppm}$. In samples of the Haupschiefer from Middle Gottland Se content ranged from 1.9 to 7.3 , and from vein zones in the Haupschiefer, from 0.30 to $4.28 \mathrm{ppm}$. The relationship between the formation of the shales and the Se content could not be fixed.-EBT

00140 Lindgren, Waldemar. Gold and silver in shales from western Kansas: U.S. Geol. Survey Bull. 202, 21 p., 1902.

Samples of dark-gray to black shale were collected in Ellis and Rush Counties, Kans., from the Benton Group of Cretaceous age. In all, 77 assays were made of material taken from 19 samples. In the samples analyzed by Lindgren, the $\mathrm{Ag}$ content ranged from 0 to $0.095 \mathrm{oz}$ per ton $[\sim 3.2 \mathrm{ppm}]$ and the Au content, from 0 to $0.005 \mathrm{oz}$ per ton $[\sim 0.17 \mathrm{ppm}]$. Analyses made by the Mint Bureau show the Ag content as ranging from 0 to $0.5 \mathrm{oz}$ per ton $[\sim 17 \mathrm{ppm}]$ and the $\mathrm{Au}$ content, from 0 to $0.05 \mathrm{oz}$ per ton $[\sim 1.7 \mathrm{ppm}$ ]. [Conversion factor used: $1 \mathrm{oz} / \mathrm{t} \cong 34 \mathrm{ppm}$.] EBT

00141 Litvin, S. V. Malye elementy $\mathrm{v}$ verkhnekamennoyugol'nykh otlozheniyakh Donbassa i severovostochoy chasti Dneprovsko-Donetskoy vpadiny [Trace elements in the Upper Carboniferous deposits of the Donets Basin and the northeastern part of the Dnieper-Donets basin]: Akad. Nauk SSSR Doklady, v. 152, no. 6, p. 14531456, 1963; English translation: Acad. Sci. USSR Doklady, Earth Sci. Sec., Am. Geol. Inst., v. 152, p. 202-205.

Spectrographic analyses of Upper Carboniferous rocks of the Donets and DnieperDonets basins show that generally distribution and concentration of trace elements depend on their geochemical characteristics and on mode of transport. Only $\mathrm{Cu}$, $\mathrm{Ba}, \mathrm{Sr}$, and $\mathrm{Mn}$ were noticeably redistributed during diagenesis and epigenesis. Average contents in marine clay and siltstone beds showed the following ranges in the Dnieper-Donets basin (in ppm): $\mathrm{Zr} 80-210$, Be 1.6-3, Ni 20-57, $\mathrm{Cr} 23-$ 
130, Ti 1,200-3,000, V 70-190, Cu 7-67, Mn 230-1,100, Ba 130-200, Sr 120-850; in the Donets basin, $\mathrm{Zr} 90-150, \mathrm{Be} 1.3-3.1$, Ni 40-66, Cr 70-90, Ti 2,500-2,900, V 90-150, Cu 28-35, Mn 500-900, Ba 170, and Sr 30?-230. Averages are generally higher in the clay formations; no information is given on organic content.-EBT

00168 Lombard, J.; Moussu, R. Flozartige Kupfervorkommen in der Permo--Trias des hohen Atlas (Marokko) [Bedlike copper occurrence in the Permo-Triassic of the High Atlas (Morocco) (in German)]: Freiberger Forschungshefte, v. C 44, p. 2227,1958 .

The copper mineralization is in a thick sedimentary sequence in the High Atlas about $50 \mathrm{~km}$ east-northeast of Agadir. In the Permian and Triassic sequence both Red-Bed type and Kupferschiefer type of copper deposits occur. The shale in the Permian and Triassic contains an average of 0.7 percent $\mathrm{Cu}$. It is more than 1 $m$ thick, with a strike length of $2 \mathrm{~km}$, is fine grained, contains organic matter, is black or dull gray marly rock, probably deposited in still, reducing water. It is underlain by a sandstone that contains 0.11 percent $\mathrm{Cu}$.-EBT

Loring, D. H. See Nicholls, G. D. 00274

00142 Lositskaya, I. F. Germaniy v osadochnykh porodakh niznego karbona Tatarii i domanika Bashkirii [Germanium in the sedimentary rocks of the Tatar Lower Carboniferous and of the Bashkirian Domanik Formations], in Gulyayeva, L. A., ed., Geokhimiya nefti i neftyanykh mestorozhdenii: Akad. Nauk SSSR, Inst. Geol. i Razrabotki Goryuschikh Iskopayemykh, p. 160-167, 1962; English translation by S. Caspari, The geochemistry of oil and oil deposits: Israel Program for Scientific Translations, p. 170-178, 1964.

Organic $\mathrm{C}$ content in the deposits of Carboniferous age in Tataria ranges from 0.95 to 61.8 percent, and $\mathrm{Ge}$ content from 0.8 to $2.8 \mathrm{ppm}(0.83$ to $13 \mathrm{ppm}$ in ash). In carbonaceous shale from Tataria the average Ge content is $2.3 \mathrm{ppm}$. In the very calcareous Domanik deposits [of Late Devonian age] organic C content ranges from 0.09 to 18.51 percent and $\mathrm{Ge}$ content from 0.17 to $3 \mathrm{ppm}(0.49$ to $24 \mathrm{ppm}$ in ash). Average Ge content of Carboniferous deposits is $1.7 \mathrm{ppm}$; of Domanik, 0.79 ; of all examined rocks, 1.2. Ge content is influenced by the predominantly humic type organic substance in the Carboniferous rocks; Ge content increases with increasing organic $\mathrm{C}$ content. In Domanik deposits, which are highly bituminous and do not contain humic acids, no relation was found between $\mathrm{Ge}$ and organic $\mathrm{C}$ contents. Clayey components influence the accumulation of $\mathrm{Ge}$ in the Domanik deposits.-EBT

00143 Lotspeich, F. B.; Markward, E. L. Minor elements in bedrock, soil, and vegetation at an outcrop of the Phosphoria Formation on Snowdrift Mountain, southeastern Idaho: U.S. Geol. Survey Bull 1181-F, p. F1-F45, 1963.

In southeastern Idaho, the Permian Phosphoria Formation contains minor amounts of $\mathrm{Ba}, \mathrm{Cr}, \mathrm{Cu}, \mathrm{Mn}, \mathrm{Ni}, \mathrm{Sr}, \mathrm{V}$, and $\mathrm{Zn}$. In unweathered rock a positive correlation of $\mathrm{Sr}$ content and a rough positive correlation of $\mathrm{V}$ content with $\mathrm{P}$ content, irrespective of lithology is seen. $\mathrm{Zn}$ shows a generally positive correlation with $\mathrm{P}$ in silty rocks. An inverse correlation appears between $\mathrm{Mn}$ and $\mathrm{P}$, and a rough inverse correlation between $\mathrm{Ba}$ and $\mathrm{P}$. Metal contents of fresh phosphatic shale samples compared to those of weathered samples in the 12 lithologic units studied shows increase with weathering for $\mathrm{Ba}, \mathrm{Cr}$, and $\mathrm{V}$ in most units; $\mathrm{Zn}$ content decreased with weathering. Ranges of contents in unweathered rock are (in ppm; $P$ in percent): P $0.1-15, \mathrm{Zn} 20-7,000, \mathrm{Cu}<1-150, \mathrm{Ni}<5-350, \mathrm{Mn} 10-500$, V 35-5,000, $\mathrm{Cr} 50-2,000, \mathrm{Ba}<5-500, \mathrm{Sr} 100-3,500$; in weathered rock: $\mathrm{P} 0.1-15, \mathrm{Zn} 200-2,500$, Cu $7-500, \mathrm{Ni}<5-750, \mathrm{Mn}<10-3,500, \mathrm{~V} 20-5,000, \mathrm{Cr} 150-5,000, \mathrm{Ba}<10-750$, and Sr $100-3,500$.-EBT

00144 Love, J. D. Vanadium and associated elements in the Phosphoria Formation in the Afton area, western Wyoming, in Short papers in the geologic and hydrologic sciences: U.S. Geol. Survey Prof. Paper 424-C, p. C279-C282, 1961.

A vanadiferous zone of black shale and dark-gray mudstone near the top of the Meade Peak Member of the Permian Phosphoria Formation near Afton, Wyo., is 
described. Reserves within the area studied are estimated at 45 million tons of rock with an average grade of 0.9 percent $\mathrm{V}_{2} \mathrm{O}_{5}$ and an average thickness of $3 \mathrm{ft}$. Small amounts of $\mathrm{Se}, \mathrm{Mo}, \mathrm{Zn}, \mathrm{Ni}, \mathrm{Co}, \mathrm{Ti}, \mathrm{Cd}$, and $\mathrm{Cr}$ are present and probably were deposited contemporaneously with the rocks of the Meade Peak Member as precipitates from solution in a unique marine environment. The largest amount of $\mathrm{Se}$ found is 0.068 percent; of $\mathrm{MoO}_{2}, 0.1$; of $\mathrm{ZnO}, 1.3$; of $\mathrm{NiO}, 0.3$; of $\mathrm{Cr}_{2} \mathrm{O}_{3}$, 0.5 ; of $\mathrm{TiO}_{2}, 1.0$; and of $\mathrm{Cd}, 0.02$ percent.-EBT

00145 Love, L. G.; Murry, J. W. Biogeneic pyrite in recent sediments of Christchurch Harbour, England: Am. Jour. Sci., v. 261, no. 5, p. 433-448, 1963.

Sediment from Christchurch Harbour, England, consists of 80 percent fine sand and 20 percent pelite and is dark-gray to black below the upper 1/4-inch-thick brown oxidized layer. Microscopic pyrite grains similar to those attributed to organic structures in older rock were identified in clayey organic-rich layers. The exact pyrite-forming organism is unknown but it is probably saprophytic and invades the host soon after death, forming sulfide shortly thereafter. Knowledge of the environment of formation of pyrite is of value in understanding the early formation of pyrite in many dark shale rocks.--Authors' abs., condensed.

00163 Love, L. G. Biogenetic primary sulfide of the Permian Kupferschiefer and Marl Slate: Econ. Geology, v. 57, no. 3, p. 350-366, 1962.

The German Kupferschiefer was formed in a foul-bottomed sea, the beginning of the Permian Zechstein sea, whose upper oxygenated waters abounded in plankton and drifting plant material which was the source of the high organic content $(6$ to 20 percent) in the fine-grained dark mud. Sulfide of the Kupferschiefer includes myriads of small spheres as much as $20 \mu$ in diameter, shown to contain and enclose delicate microfossils associated with Pyritosphaera barbaria Love, also recognized in pyrite microspheres of other dark shales and some Recent sediments. These are regarded as the remains of microorganisms that caused authigenic precipitation of primary pyrite in early Zechstein sediments of Europe, including the Marl Slate of northeast England. Demonstration here of the early formation of pyrite allows consideration of early diagenetic replacement by other sulfides. Current theories of the origin of this secondary mineralization are discussed.-Author's abs., modified.

00164 Love, L. G.; Zimmerman, D. O. Bedded pyrite and micro-organisms from the Mount Isa Shale: Econ. Geology, v. 56, no. 5, p. 873-896, 1961.

The origin of the first generation pyrite of the lower Proterozoic Mount Isa Shale of Australia is considered to be syngenetic rather than epigenetic. The pyrite grains occur as infillings of a hitherto unknown type of fossil microorganism. The zonal structure found in the grains is thought to be inherited from the fossils. The microorganisms are analogous to forms of Paleozoic and Mesozoic age that are characteristic of sapropelic black shales. To the microorganisms is attributed the formation of iron sulfide syngenetically with the deposition of the enclosing sediment or during the earliest period of diagenesis. Spheres of sphalerite and galena have been observed in some of the bedded pyrite layers.-A A thors' abs., modified.

00165 Lovering, J. F.; Morgan, J. W. Rhenium and osmium abundances in tektites: Geochim. et Cosmochim. Acta, v. 28, p. 761-768, 1964.

$\mathrm{Re}$ and $\mathrm{Os}$ abundances have been determined in 10 tektites. Measurements of $\mathrm{Re}$ and Os abundances in terrestrial acid igneous and sedimentary rocks suggest that either could be suitable parent materials for tektites. Of the three sedimentary rocks examined in the present study, both the clay shale and the dark shale contained about $4 \times 10^{4} \mathrm{ppm} \mathrm{Os}$ and the quartz-rich sandstone, around $0.55 \times 10^{-4} \mathrm{ppm}$ Os. The clay shale contains $0.51 \times 10^{-4} \mathrm{ppm} \mathrm{Re}$; the dark shale (Captain's Flat Railroad Station, New South Wales, Australia) contains $825 \times 10^{-4} \mathrm{ppm}$ Re.-Authors' abs., modified.

Lovering, T.S. See Morris, H.T.00150 
00166 Lovering, T. S. Epigenetic, diplogenetic, syngenetic, and lithogene deposits: Econ. Geology, v. 58, no. 3, p. 315-331, 1963.

The term "diplogenetic" is proposed for mineralization that is partly syngenetic, partly epigenetic. Guides for distinguishing various types of deposits are discussed. Examples include syngenetic cations united with epigenetic anions, as in fluorite replacements in limestones, and epigenetic cations united with syngenetic $S$ or other anions, as may be true in certain black copper shales of the Mansfeld type. Criteria developed are used to review critically several controversial deposits such as the African copper belt and the graphitic schists of Fenno-Scandia.-Author's abs., condensed.

00160 Lundegårdh, P. H. Aspects to the geochemistry of chromium, cobalt, nickel, and zinc (in English): Sveriges Geol. Undersökning, Ser. C, n:o 513, Ärsb. 43, n:o 11, 56 p., 1949.

Principal minor element determinations-especially those that may elucidate the geochemistry of $\mathrm{Cr}, \mathrm{Co}, \mathrm{Ni}$, and $\mathrm{Zn}$-on Swedish minerals, rocks, and soils are summarized. Some of these data are new and some are from earlier papers. High values in clay sediments containing significant amounts of organic material are probably due to enrichment by adsorption on the organic material. In Swedish clay sediments, the order of distribution is generally as follows: $\mathrm{Cr}<\mathrm{Co}<\mathrm{Ni}<\mathrm{Zn}$. Impure clay sediments containing significant organic matter show the following amounts (in ppm): early Svionian (early Archaean) black slate, graphite-bearing, Orebro län, $\mathrm{Cr} 6$, Co $<2, \mathrm{Ni} 10, \mathrm{Zn} \mathrm{400;} \mathrm{Gotho-Karelian} \mathrm{(late} \mathrm{Archaean)} \mathrm{black}$ slate, graphitic and pyritic, Södermanlands län, $\mathrm{Cr} 10$, Co $50, \mathrm{Ni} 180, \mathrm{Zn} \mathrm{300;}$ Cambrian black alum shale (Paradoxides Tessini), Alvsborgs lan, $\mathrm{Cr} 15, \mathrm{Co} 30, \mathrm{Ni}$ $70, \mathrm{Zn} 200$; Ordovician black alum shale (Dictyonema), Cr 30, Co $<2$, Ni 25, Zn 400.-EBT

00162 Lundegairdh, P. H. Some aspects to the determination and distribution of zinc (in English): Kungl. Lantbrukshögskolans Ann., v. 15, p. 1-36, 1948.

In central and southern Sweden, average $\mathrm{Zn}$ content in clay slates is $100 \mathrm{ppm}$; in Precambrian and Paleozoic clay slates it is $200-250 \mathrm{ppm}$ and varies little with different ages and origins. Clay slates containing organic matter, such as alum shales and similar rocks, should show enrichments of $\mathrm{Zn}$, but $\mathrm{Zn}$ contained in organic or inorganic sediments is seldom uniformly distributed owing to variable $\mathrm{Zn}$ contents in the deposited material and in secondary circulating solutions. $\mathrm{Zn}$ contents reported in some gray to black shales are (in ppm): Archean of Västmanland, black graphite-bearing shale 400, dark-gray clay slate 200; in Västergötland, Cambrian black alum shale (Paradoxides Tessini) 200; Ordovician gray clay slate (Tretaspis slate) 200; in Óland, Cambrian clay slate (Ölandicus slate) 200; Ordovician black alum shale (Dictyonema shale) 400 . Contents in other rocks and analytical methods are also discussed.-EBT

00167 Lundegårdh, P. H. Rock composition and development in Central Roslagen, Sweden (in English): Arkiv Kemi, Mineralogi, Geologi, v. 23A, no. 4-5, N:o 9, 160 p., 1947.

Analyses of Cambrian, Ordovician, and Silurian sedimentary rocks from Västergötland, central Sweden, are included for comparison to the analyses of the igneous and metamorphic rocks of Central Roslagen, Sweden. Bituminous schist from Byklev, Hunneberg, contains (in ppm): V 1,000, Cr 15, Co 30, and $\mathrm{Ni} 70$.EBT

Lyden, E. F. X. See Merrill, J. R. 00148

Lygalova, V. N. See Itkina, E. S. 00223

Mahadevan, C. See Murty, P. S. N. 00271

Mahoney, S. R. See Allsman, P. T. 00020 


\section{BIBLIOGRAPHY OF MINOR ELEMENTS IN BLACK SHALES}

Mahoney, S. R. See Allsman, P. T. 00021

Majors, F. H. See Allsman, P. T. 00020

Majors, F. H. See Allsman, P. T. 00021

Makarova, A. I. See Ronov, A. B. 00252

Malyuga, D. P. See Ronov, A. B. 00252

00159 Manheim, F. T. A geochemical profile in the Baltic Sea: Geochim. et Cosmochim. Acta, v. 25, p. 52-70, 1961 b.

An investigation of the relationship between depositional environment and element distribution in sediments from the Baltic Sea showed maximum heavy-metal contents not in the central, most stagnant and organic-rich parts, but in the peripheral transition zone characterized by aerated bottom water but moderately reducing sediment environment. Element contents as high as (in ppm) $250 \mathrm{Cu}$, $250 \mathrm{Zn}, 32 \mathrm{U}, 80 \mathrm{Mo}$, and $1.6 \mathrm{Ag}$ were found in the peripheral areas; incomplete data for $\mathrm{Sn}$ and $\mathrm{Pb}$ indicate the same pattern. Mo is a possible exception; it probably coprecipitates with iron sulfides. $\mathrm{Mn}$ is enriched in 2 of the Baltic deeps, in one case reaching 5.2 percent $\mathrm{MnO}$. Trace-element contents in a sample of $\mathrm{Mn}$-rich deep bottom mud were (in ppm): F 530, B 115, Sr 130, Ba 750, Li 38, Rb 150, Ni 43, Co 22, Cr 90, V 130, Mo 35, Cu 78, Zn 110, Pb 25, Sn 8, Ag <1, Ga 30, U 7, Th 11, and organic C 4.6 percent.--EBT

00161 Manheim, F. T. Chemical investigations in the Baltic Sea (in English) [abs.]: Geol. Fören. Stockholm Förh., v. 83, p. 314-315, 1961a.

The relationship between depositional environment and element distribution in sediments from the Baltic Sea has been investigated. A prominent feature of the central Baltic is its salinity stratification, which gives rise to changes in bottom sediment character from oxidation to stagnation as greater depths are approached. Maximum heavy metal concentrations were not found in the central, most stagnant and organic-rich parts of the basins, but in the transition zone to stagnant conditions. In such areas $\mathrm{Cu}, \mathrm{Zn}, \mathrm{Pb}$, and $\mathrm{Ag}$ appeared to be enriched in the sediments by precipitation from the water as sulfides. $U$ was also enriched and concentrations as much as $32 \mathrm{ppm}$ were found in surficial postglacial sediments.Author's abs., modified.

Manheim, F. T. See Landergren, Sture. 00175

00407 Mapel, W. J. Uranium in black shale deposits, northern Rocky Mountains and Great Plains: U.S. Geol. Survey Bull. 1030-H, p. 211-235, 1956.

Reconnaissance examinations for $U$ in 22 formations containing black shale were made in parts of Montana, North Dakota, Utah, Idaho, and Oregon. About 150 samples from 80 outcrop localities and 5 oil and gas wells were submitted for $U$ determinations; most contained less than $30 \mathrm{ppm} \mathrm{U}$. However, samples from thin beds of black shale at the base of the Mississippian System from 2 outcrops in southwestern Montana contain $50 \mathrm{ppm} \mathrm{U}$; samples from a well in northeastern Montana, as much as $70 \mathrm{ppm}$. Samples of phosphatic black shale at the base of the Mississippian Brazer Limestone in Rich County, Utah, contain as much as 90 ppm U. Commercial gamma-ray logs from wells in Montana and the Dakotas indicate that locally the Heath Shale of Late Mississippian age contains $100 \mathrm{ppm}$ equivalent $U$ and black shales of Late Cretaceous age, $80 \mathrm{ppm}$ equivalent $U$. Author's abs., condensed.

Markward, E. L. See Lotspeich, F. B. 00143

00146 Marmo, Vladi. On the sulphide and sulphide-graphite schists of Finland (in English): Finlande Comm. Géol. Bull. 190, 80 p., 1960.

The Precambrian sulfide and sulfide-graphite schists of Finland occur along belts and zones that tend to surround the central mountain igneous cores. The sulfide 
and sulfide-graphite schists have derived from sapropelitic and "gyttja" sediments whose composition ranged from carbonaceous and sulfide-bearing pelites to marls and calcareous muds, subjected to regional metamorphism. These schists generally contain appreciable amounts of minor elements typical of sapropels. Average heavymetal contents of sulfide schists of the Nokia region are (in ppm; maximum in parentheses): $\mathrm{Cu} 120(450)$, Ni $250(1,500), \mathrm{Zn} \mathrm{1,470}(2,700), \mathrm{V} \sim 100$ (300), Mo $30(100)$, and $\mathrm{Cr}<100(<100)$; of sulfide-graphite schists of Pohjanmaa: $\mathrm{Cu} 1,100$ $(>5,000)$, Ni $560(1,700)$, Co $70(700)$, Zn $930(6,500)$, V $160(1,400)$, Mo $20(230)$, and $\mathrm{Cr} 120(600)$. The average of all schists is: $\mathrm{Cu} 650, \mathrm{Ni} 510, \mathrm{Co} 70, \mathrm{Zn} \mathrm{1,040,}$ $\mathrm{V} 150$, Mo 25, and $\mathrm{Cr} \sim 100$. - EBT

00408 Marmo, Vladi. Schungite-a pre-Cambrian carbon (in English): Geol. Fören. Stockholm Förh., v. 75, no. 1, p. 89-96, 1953.

Schungite consists of black amorphous relatively pure carbon resembling anthracite in its luster and hardness, but having a much higher point of inflammability and a higher content of silicate impurities. It occurs in Russian Karelia as thick layers and as finely disseminated material in dolomite and pelite beds of Jatulian [Precambrian] age. Relatively high amounts of $\mathrm{V}, \mathrm{Ti}, \mathrm{Mo}, \mathrm{W}, \mathrm{Zr}, \mathrm{Cu}, \mathrm{Ni}$, and $\mathrm{Ba}$ are found in the ash. However the ash from shungite burned after having impurities mechanically separated from it showed only $10 \mathrm{ppm} \mathrm{V}$, less than 1,000 ppm $\mathrm{Zn}$ and $\mathrm{Cu}, 100-1,000 \mathrm{ppm} \mathrm{Mn}$, about $100 \mathrm{ppm} \mathrm{Cr}, \mathrm{B}, \mathrm{Sr}, \mathrm{Pb}, \mathrm{Sn}, \mathrm{Ga}, \mathrm{Mo}$, $\mathrm{Ni}$, and $\mathrm{As}$, and about $10 \mathrm{ppm} \mathrm{Be}$ as determined spectrographically.-EBT

00147 Maurel, P. Etude minéralogique et géochemique des formations argileuses des environs de Saint-Affrique (Aveyron) [Mineralogical and geochemical study of argillaceous formations in the Saint Affrique area, Aveyron (in French)]: Soc. française minéralogie et crystallographie Bull., v. 85, no. 4, p. 329-374, 1962.

An argillaceous sedimentary series of Late Permian to Liassic age was studied. The black marine marls of the Lias consist of a mixture of illite, kaolininte, vermiculite (chlorite replaces vermiculite in the upper levels), sulfides, and organic matter. The argillaceous Liassic rocks had the following mean trace-element content (in ppm): Li 141, B 152, P 663, Cl 84, Ti 4,440, V 148, Cr 148, Mn 666, $\mathrm{Co} 14, \mathrm{Ni} 62, \mathrm{Cu} 37, \mathrm{Rb} 70, \mathrm{Sr} 413$, and $\mathrm{Ba} 287$,--EBT

00157 Mayzko, J. J. Phosphate rock from the Brooks Range, northern Alaska: A preliminary mineralogic report [abs.]: Geol. Soc. America Bull., v. 66, no. 12, pt. 2, p. 1705, 1955.

Phosphorite occurs in the Mississippian Lisburne Group in northern Alaska on the north flank of the Brooks Range. Preliminary studies on about 100 samples collected, by U.S. Geological Survey geologists, from the phosphatic zone of the Lisburne indicate that it is very similar in lithology and P, U, and V content to the Phosphoria Formation of Idaho, Wyoming, Utah, and Montana. The phosphatic zone is composed of phosphorite, phosphatic limestone, and phosphatic mudstone. The phosphorite generally contains from 20 to 30 percent $\mathrm{P}_{2} \mathrm{O}_{5}$, but an analysis of two selected beds shows as much as 34.0 percent $\mathrm{P}_{2} \mathrm{O}_{5}, 0.49$ percent $\mathrm{V}_{2} \mathrm{O}_{5}$, and 0.024 percent $\mathrm{U}$. The phosphorites are generally highly stained by carbonaceous matter to a dark brown or black.--Author's abs., condensed.

00158 McKelvey, V. E.; Strobell, J. D., Jr. Preliminary geologic maps of the ParisBloomington vanadium area, Bear Lake County, Idaho: U.S. Geol. Survey Mineral Inv. Field Studies Map MF-4I, 1955.

Vanadiferous mudstone and phosphorite occur about 35 feet below the top of the Meade Peak Phosphatic Shale Member of the Permian Phosphoria Formation near Paris and Bloomington, Bear Lake County, Idaho. V data and preliminary geologic maps are presented. Samples from the Bloomington Canyon area contained 0.081.51 percent $\mathrm{V}_{2} \mathrm{O}_{5}$ in shale and 0.07-1.03 percent (weighted averages) in siltstone, phosphorite, and shale. Samples from the Paris Canyon area contained 1.13-1.85 percent $\mathrm{V}_{2} \mathrm{O}_{5}$ in shale and $0.68-1.40$ percent (weighted averages) in siltstone, phosphorite, and shale.-EBT 
McViker, L. D. See Ostrom, M. E. 00267

Meinschein, W. G. See Barghoorn, E. S. 00010

00148 Merrill, J. R.; Lyden, E. F. X.; Honda, M.; Arnold, J. R. The sedimentary geochemistry of the beryllium isotopes: Geochim. et Cosmochim. Acta, v. 18, p. $108-129,1960$.

The sedimentary geochemistry of Be has been investigated with a view toward the use of cosmic-ray produced $\mathrm{Be}^{10}$ for geochronology. Analysis of some Pacific Ocean water samples gives an average total Be content of $6 \times 10^{-7} \mathrm{ppm}$, less than half of which is retained by a Millipore filter. The concentration of $\mathrm{Be}^{9}$ in 5 deep ocean sediment cores ranges from 2 to $3 \mathrm{ppm}$. These data indicate an ocean residence time for $\mathrm{Be}$ of the order of a few hundred years. An abrupt change in $\mathrm{Be}^{10}$ content with depth in a Pacific sediment core correlates with a change in the ionium-thorium ratio reported by Holdberg and Koide for the same core.-Authors' abs., condensed.

Migdisov, A. A. See Balashov, Yu. A. 00024

Miller, J. T. See Byers, H. G. 00063

00155 Minami, E. Selen-Gehalte von europäischen und japanischen Tonschiefern [Selenium contents of European and Japanese clay shales (in German)]: Gesell. Wiss. Göttingen Nachr., math.-phys. K1., v. 1, p. 143-145, 1935 a.

Analysis of a composite sample of 36 European Paleozoic shales (C content 1.91 percent) showed $1.2 \mathrm{ppm} \mathrm{Se}$. Analysis of 14 Japanese Paleozoic shales showed 0.24 ppm Se, and of 10 Mesozoic Japanese shales, 0.38 ppm Se.-EBT

00180 Minami, E. Gehalte an seltenen Erden in europäischen und japanischen Tonschiefern [Content of rare earths in European and Japanese shales]: Gesell. Wiss. Göttingen Nachr. math.-phys. K1., Geologie u. Mineralogie, v. 1, no. 14, p. $155-170,1935 b$.

A method of X-ray spectrographic analysis of chemically enriched samples of shale for rare earth elements is described. In composite samples of shale the following amounts of rare earths were found (in ppm): 36 European shales of Paleozoic age: $\mathrm{Cp}_{2} \mathrm{O}_{3}\left[\mathrm{Lu}_{2} \mathrm{O}_{3}\right]$ 1.3, $\mathrm{Yb}_{2} \mathrm{O}_{3} 4.4, \mathrm{Tu}_{2} \mathrm{O}_{3}\left[\mathrm{Tm}_{2} \mathrm{O}_{3}\right] \quad 0.3, \mathrm{Er}_{2} \mathrm{O}_{3} 3.8, \mathrm{Ho}_{2} \mathrm{O}_{3} 2.2, \mathrm{Dy}_{2} \mathrm{O}_{3}$ 7.1, $\mathrm{Tb}_{2} \mathrm{O}_{3} 1.2, \mathrm{Gd}_{2} \mathrm{O}_{3} 9.8, \mathrm{Eu}_{2} \mathrm{O}_{3}$ 1.4, $\mathrm{Sm}_{2} \mathrm{O}_{3} 8.8,61[\mathrm{Pm}]--, \mathrm{Nd}_{2} \mathrm{O}_{3} 32.2, \mathrm{Pr}_{2} \mathrm{O}_{3}$ 5.7, $\mathrm{CeO}_{2} 40.1 ; \mathrm{La}_{2} \mathrm{O}_{3}$ 19.1, $\mathrm{Y}_{2} \mathrm{O}_{3} 37.8, \mathrm{ThO}_{2}$ 10.5; 14 Japanese shales of Paleozoic age: $\mathrm{Lu}_{2} \mathrm{O}_{3} 0.41, \mathrm{Yb}_{2} \mathrm{O}_{3} 3.2, \mathrm{Tm}_{2} \mathrm{O}_{3} 0.23, \mathrm{Er}_{2} \mathrm{O}_{3} 2.5, \mathrm{Ho}_{2} \mathrm{O}_{3} 0.96, \mathrm{Dy}_{2} \mathrm{O}_{3} 3.9, \mathrm{~Tb}_{2} \mathrm{O}_{3}$ $0.64, \mathrm{Gd}_{2} \mathrm{O}_{3}$ 6.6, $\mathrm{Eu}_{2} \mathrm{O}_{3} 1.2, \mathrm{Sm}_{2} \mathrm{O}_{3}$ 7.7, $\mathrm{Pm}--, \mathrm{Nd}_{2} \mathrm{O}_{3}$ 24.4, $\mathrm{Pr}_{2} \mathrm{O}_{3}$ 6.9, $\mathrm{CeO}_{2} 59.8$, $\mathrm{La}_{2} \mathrm{O}_{3} 26.2, \mathrm{Y}_{2} \mathrm{O}_{3} 35.7$, $\mathrm{ThO}_{2} 11.2 ; 10$ Japanese shales of Mesozoic age: $\mathrm{Lu}_{2} \mathrm{O}_{3}$ $0.54, \mathrm{Yb}_{2} \mathrm{O}_{3} 1.5, \mathrm{Tm}_{2} \mathrm{O}_{3} 0.15, \mathrm{Er}_{2} \mathrm{O}_{3} 2.2, \mathrm{Ho}_{2} \mathrm{O}_{3} 1, \mathrm{Dy}_{2} \mathrm{O}_{3} 4.4, \mathrm{~Tb}_{2} \mathrm{O}_{3} 1.3, \mathrm{Gd}_{2} \mathrm{O}_{3}$ 5.6, $\mathrm{Eu}_{2} \mathrm{O}_{3} 1.1, \mathrm{Sm}_{2} \mathrm{O}_{3} 6, \mathrm{Pm}--, \mathrm{Nd}_{2} \mathrm{O}_{3}$ 26.7, $\mathrm{Pr}_{2} \mathrm{O}_{3}$ 7.1, $\mathrm{CeO}_{2}$ 69.9, $\mathrm{La}_{2} \mathrm{O}_{3}$ 19.4, $\mathrm{Y}_{2} \mathrm{O}_{3}$ 33.6, $\mathrm{ThO}_{2}$ 14.3.--EBT

00156 Mohr, P. A. A geochemical study of the shales, of the Lower Cambrian Manganese Shale Group of the Harlech Dome, North Wales: Geochim. et Cosmochim. Acta, v. 17, p. 186-200, 1959.

The shales of the Manganese Shale Group are characterized geochemically by their relatively high $\mathrm{Mn}$ content, the predominance of ferrous iron over ferric iron, the sympathetic behavior of $\mathrm{Co}, \mathrm{Ni}, \mathrm{Cr}$, and $\mathrm{V}$ with total $\mathrm{Fe}$, and inverse relationship of $\mathrm{Sr}$ and $\mathrm{Ba}$, and a direct relationship of $\mathrm{B}$ and $\mathrm{Ba}$. Evidence indicates that the sources rocks of the Manganese Shales were acid gneisses. Average minor-element contents are (in ppm): B 105, Be 1, Cr 76, V 165, Li 2-120, Ni 68, Co 27, Zr $230, \mathrm{Cu} 70, \mathrm{Sr} 85, \mathrm{Ba} 750$.- EBT

00149 Moore, D. M.; Henderson, D. M. Selected trace elements of the White Pine Group, eastern Nevada [abs.]: Geol. Soc. America Spec. Paper 76, p. 117, 1964.

Vertical and horizontal distributions of 7 trace elements were determined by quantitative emission spectrography for the thick, argillaceous, Mississippian White Pine Group in eastern Nevada. Distributions were described, with the aid of 
standard computer routines, in terms of correlation and multiple-regression coefficients for 12 groupings of 106 samples. Average abundances (in ppm) were: B 187, V 140, Cu 85, Ni 72, Ga 29, Sc 25, and Co 11. Standard deviations for all except $\mathrm{V}$ are less than 80 percent. Distinctive element-to-element relationships can be recognized with respect to lithology, mineralogy, stratigraphic position, and geographic location. The pair $\mathrm{Ni}$ Cu shows the strongest covariance; $\mathrm{V}: \mathrm{Cu}: \mathrm{Ni}, \mathrm{B}: \mathrm{Ni}$, $\mathrm{V}: \mathrm{Ga}, \mathrm{V}: \mathrm{Cu}, \mathrm{Cu}: \mathrm{Ga}$, and $\mathrm{Co:Ga}$ also show strong covariance. The observed abundances and relationships probably reflect those of the parental Ordovician black shales and the influence of the biology of the depositional basin.-Authors' abs., condensed.

Morgan, J. W. See Lovering, J. F. 00165

Morita, Yoshimi. See Sugawara, Ken. 00276

00150 Morris, H. T.; Lovering, T. S. Stratigraphy of the East Tintic Mountains, Utah: U.S. Geol. Survey Prof. Paper 361, 145 p., 1961 [1962].

Consolidated sedimentary rocks exposed in the East Tintic Mountains in central Utah are of late Precambrian to Permian ages and exceed 30,000 feet in total thickness. They are marine sediments deposited on the eastern shelf areas of the great Paleozoic geosyncline of the Great Basin area. Mean element content of 35 drill-core samples of the phosphatic shale member of the Upper Mississippian Deseret Limestone from semiquantitative spectrographic analyses is (concentrations bracketed into groups each of about $1 / 3$ order of magnitude; $X+10-5, X$ 5-2, and $\mathrm{X}-2-1$; in percent): $\mathrm{Na} 0.0 \mathrm{X}+, \mathrm{Be}$ tr, $\mathrm{Mg} 0 . \mathrm{X}, \mathrm{Ca} 0 . \mathrm{X}_{+}, \mathrm{Sr} 0.0 \mathrm{X}-, \mathrm{Ba} 0.00 \mathrm{X}+$, Sc $0.000 \mathrm{X}$, Y $0.0 \mathrm{X}-$, La $0.00 \mathrm{X}$, Ti $0.0 \mathrm{X}, \mathrm{Zr} 0.00 \mathrm{X}+$, V $0.0 \mathrm{X}+$, Cr $0.0 \mathrm{X}-$, Mo $0.00 \mathrm{X}-$, $\mathrm{Mn} 0.0 \mathrm{X}-, \mathrm{Fe} 0 . \mathrm{X}$, Co $0.000 \mathrm{X}-$, Ni $0.00 \mathrm{X}+$, Cu 0.00X, Ag $0.00 \mathrm{X}-, \mathrm{Zn} 0.0 \mathrm{X}+$, Cd 0.00X--, B 0.00X-, Al X.-, Ga 0.000X-, Si XX., Pb 0.000X-, and P X.--EBT

Moussu, R. See Lombard, J. 00168

Movileanu, Aurelia. See Savul, Mircea. 00234

00154 Moxon, A. L.; Olson, O. E.; Searight, W. V.; Sandals, K. M. The stratigraphic distribution of selenium in the Cretaceous formations of South Dakota and the selenium content of some associated vegetation: Am. Jour. Botany, v. 25, no. 10, p. $794-809,1938$.

Se occurs in all Cretaceous formations in South Dakota from the Dakota Sandstone up through the Pierre Shale, but content in the Dakota, Graneros, Greenhorn, and Carlile Formations is generally low. Se content is high in the Smoky Hill Member of the Niobrara Formation and in the Sharon Springs and Mobridge Members of the Pierre Shale. In core from Irish Creek well, Ziebach County, Se content ranged from 12 to $22 \mathrm{ppm}$ in the Smoky Hill Member, 4.5 to $18 \mathrm{ppm}$ in the Sharon Springs Member, and 0.0 to $5 \mathrm{ppm}$ in the Mobridge. Samples of the Smoky Hill from Yankton showed 2-16 ppm Se, samples from Lyman County (2 composites), 24, $28 \mathrm{ppm}$, and samples from eastern South Dakota, 3.5, 6.5 ppm. Samples of the Sharon Springs from Yankton showed $45 \mathrm{ppm}$ Se. Se content in the Mobridge Member is known to range from 0.0 to $103 \mathrm{ppm}$; an inverse correlation between the thickness of the formation and Se content is suggested.-Authors' summ., modified.

00238 Moxon, A. L.; Olson, O. E.; Searight, W. V. Selenium in rocks, soils and plants: South Dakota Agr. Expt. Sta. Tech. Bull. 2, 94 p., 1939.

Seleniferous areas in South Dakota have been studied in detail. Se is concentrated in Upper Cretaceous sediments and is associated with carbonate, pyrite, and organic matter in fine-grained sediments. It is probably concentrated in reducing environments. Se contents (in ppm) in gray to black marine shales are: Greenhorn Formation, range 0.0-6.0; Niobrara Formation, Smoky Hill Member, range 2-45, average in Lyman County 32.9; Pierre Shale, Sharon Springs Member, range 045, average in Lyman County 24; Pierre Shale, Virgin Creek Member, range $0.0-$ 2.5 , average 1, range in Gregory County 6-52, average 26.-EBT 
00239 Moxon, A. L.; Searight, W. V.; Olson, O. E.; Sisson, L. L. Arsenic content of South Dakota Cretaceous formations: South Dakota Acad. Sci. Proc., v. 24, p. $68-81,1944$.

Samples of Upper Cretaceous marine sedimentary rocks were analyzed for As in connection with the Se problem because it has been found that As counteracts the toxic effects of Se. Upper Cretaceous gray to black marine shales contained the following amounts of As and Se (range in ppm): Greenhorn Formation, As 4.222, Se 0.0-3.2; Niobrara Formation, Smoky Hill Member, As 0.2-59, Se 0.5-45; Pierre Shale, Sharon Springs Member, As 4.7-43, Se 3-24; Pierre Shale, Virgin Creek Member, As 3-16, Se 0.0-6.-EBT

00151 Muilenburg, G. A.; Keller, W. D. Carnotite and radioactive shale in Missouri: Am. Mineralogist, v. 35, nos. 3-4, p. 323-324, 1950.

Carnotite and possibly other radioactive minerals have been found in the Mississippian Spergen Limestone in a quarry abount 5-1/2 miles north of Ste. Genevieve, Mo. The carnotite was first noticed as a thin film of yellow substance along a joint in a block of limestone. A highly radioactive thin bed of black shale was found separating two limestone beds. This shale parting is thought to be the source of the carnotite in the limestone below. The carnotite is visible only a few places in the shale. An X-ray diffraction pattern of the black shale where no carnotite was visible indicates that the clay mineral is illite and the spectrographic analysis shows that the shale contains $U$ and $V$. A tentative hypothesis is that the illite contains these elements.-EBT

Müiller, German. See Seibold, Eugen. 00304

00152 Mullin, J. B.; Riley, J. P. The occurrence of cadmium in seawater and in marine organisms and sediments: Jour. Marine Research, v. 15, no. 2, p. 103-122, 1956.

A method has been developed, based on the dithizone extraction method of Saltzman, capable of detecting less than 10 millimicrograms of Cd in sea water, marine organisms, and marine sediments. It can be used for determining $\mathrm{Cd}$ in silicate rocks; only $\mathrm{Tl}$ interferes. Mean values of $\mathrm{Cd}$ in diatomaceous oozes $(0.39$ $\mathrm{ppm})$, globigerina oozes $(0.42)$, and radiolarian oozes $(0.45)$ are close to the mean reported by Goldschmidt for the crustal abundance of Cd. Two organic mud samples $(1.2,1.3$ percent organic C) from the Irish Sea contain 0.417 and 0.363 $\mathrm{ppm} \mathrm{Cd}$ which indicates that part of their $\mathrm{Cd}$ is associated with organic detritus. Assuming the concentration of undecayed organisms in the mud was about twice the organic $\mathrm{C}$ content found, then the concentration of $\mathrm{Cd}$ in the original organisms was about $4 \mathrm{ppm}$, which is of the same order as that actually found in marine organisms.-EBT

00153 Murata, K. J.; Erd, R. C. Composition of sediments from the experimental Mohole project (Guadalupe site): Jour. Sed. Petrology, v. 34, no. 3, p. 633-655, 1964.

Mineralogic and chemical analyses were made on 34 sediment samples from the Guadalupe site. They consist chiefly of calcite, opal, and normal lithogenic matter probably deposited intermediate between nearshore and pelagic environment. Covariance of $\mathrm{MgO}, \mathrm{MnO}$, and $\mathrm{P}_{2} \mathrm{O}_{5}$ suggests derivation from basalt. Concentrations of Ba may be inversely related to rate of deposition. Spectrographic analyses show the following range in trace-element content (in ppm): $\mathrm{Cr} 20-100$, Ni 23-230, Co nd-15, V 7-160, Cu 51-340, Pb nd-70, Mo nd -15, Sr 270-3,000, Ba 300-7,600, La nd-300, Y 30-100, Zr 30-1,000, Be nd-5, and Ga nd-30. Maxima for $\mathrm{Mo}, \mathrm{La}, \mathrm{Y}, \mathrm{Zr}$, and $\mathrm{Be}$ occurred in pyroclastic sand and for $\mathrm{Ni}, \mathrm{Cu}$, and $\mathrm{Pb}$, in clayey siliceous ooze. Lithogenic matter contained (in ppm): $\mathrm{Cr} 76, \mathrm{Ni} 150$, Co 16, Cu 180, V 120, Mn 1,500, and Ti 4,600.--EBT and JDV

Murphy, W. I. R. See Thorne, H. M.00287

00402 Murray, H. H. Genesis of clay minerals in some Pennsylvanian shales of Indiana and Illinois, in Swineford, Ada, and Plummer, Norman, eds., Clays and clay minerals, 1953: Natl. Acad. Sci., Natl. Research Council Pub. 327, p. 47-67, 1954. 
Shales of marine, brackish-water and nonmarine origin, collected from cyclothems of Pennsylvanian age, were analyzed chemically and mineralogically. In raw shales, only $\mathrm{V}, \mathrm{Sr}$, and $\mathrm{Ba}$, of the elements looked for, showed significant variation in average values between the 3 origins; $V$ is highest in brackish-water shales which are usually dark-colored and contain more organic matter. Nonmarine shales have the highest average contents of $\mathrm{Ba}$ and $\mathrm{Sr}$, and brackish-water shales the lowest. Average contents of marine shales are (in ppm): V 126, Cr 99, M n 341, Sr 166,

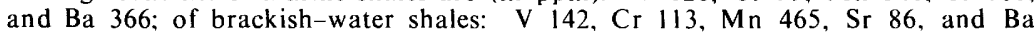
284. The range of contents in dark-gray to black marine shales is $V<100-190$, $\mathrm{Cr} 95-160, \mathrm{Mn} 180-520, \mathrm{Sr} 110-330$, Ba 200-350, and $\mathrm{Ni}$ nd-<50; in dark brackishwater shales: V 110-200, Cr 110-190, Mn 170-400, Sr 47-140, Ba 190-410, and Nind-160.-EBT

Murray, J. W. See Love, L. G. 00145

00271 Murty, P. S. N.; Aswathanarayana, U.; Mahadevan, C. Geochemistry of the siliceous black shales at Nagarjunasagar damsite, India: Econ. Geology, v. 57, no. 4, p. 614-616, 1962.

Black shales occur in lenses in a sedimentary sequence of Precambrian age believed to correspond to the Srisailam Stage of the Cuddapah System. Pyrite occurs in these shales as minute crystals and lenses. The $U$ content ranges from 0.06 to 0.52 $\mathrm{ppm}$, the organic $\mathrm{C}$ content from 0.07 to 0.70 percent; and the S content from 0.14 to 1.30. The organic $\mathrm{C}$ content bears a fairly direct relationship to the contents of $S$ and iron in the sulfide. $S$ and $U$ contents are directly related. The Nagarjunasagar dam is between Madras and Hyderabad.-EBT

00272 Mustafa, Ahmed; Ghaly, E. L. Survey of Qusseir shales and other carbonaceous shales in Egypt: Jour. Chem. Eng. Data, v. 9, no. 4, p. 557-567, 1964.

Samples of carbonaceous shales were collected from different localities in Egypt and subjected to general analysis. Of these, 3 samples from the area between Gebel Hamadat and Gebel Dawi (Qusseir) were chosen for detailed analysis. The Qusseir oil shale of Late Cretaceous age is a hard rock, ranging in color from gray to black, and consisting of banded clay and disseminated carbonaceous matter and iron oxides: shells of foraminifera occur in notable amounts. Organic content ranges from 21.08 to 22.21 percent in the 3 samples: $\mathrm{P}_{2} \mathrm{O}_{5,}$, from 3.5 to 4.8 percent: and ash, from 62.7 to 63.5 percent. Semiquantitative spectrographic analyses of the ash of the 3 samples showed the following amounts: Sample Q15, $\mathrm{Zn}, \mathrm{Ti}, \mathrm{Mn}$ from 1 to 0.1 percent: $\mathrm{Cr}, \mathrm{Cu}, \mathrm{Ag}, \mathrm{Mo}, \mathrm{Cd}, \mathrm{V}, \mathrm{Ni}$ from 0.1 to 0.01 percent; $\mathrm{B}$, $\mathrm{Ga}, \mathrm{Pb}, \mathrm{Ba}, \mathrm{Sn}, \mathrm{Yb}$ less than 0.01 percent. Sample Q16, $\mathrm{Zn}, \mathrm{Ti}, \mathrm{Mn}$ from $\mathrm{I}$ to 0.1 percent; $\mathrm{Cr}, \mathrm{Cu}, \mathrm{Mo}, \mathrm{V}$ from 0.1 to 0.01 percent; $\mathrm{Ag}, \mathrm{B}, \mathrm{Ga}, \mathrm{Pb}, \mathrm{Ba}, \mathrm{Sn}, \mathrm{Yb}$, $\mathrm{Ni}, \mathrm{Cd}$ less than 0.01 percent. Sample Q17, $\mathrm{Zn}, \mathrm{Ti}, \mathrm{Mn}$ from 1 to 0.1 percent: $\mathrm{Cr}, \mathrm{Cu}, \mathrm{Mo}, \mathrm{V}, \mathrm{Cd}, \mathrm{Ni}$ from 0.1 to 0.01 percent: $\mathrm{Ag}, \mathrm{B}, \mathrm{Ga}, \mathrm{Ba}, \mathrm{Pb}, \mathrm{Sn}, \mathrm{Yb}$ less than 0.01 percent.-EBT

00273 Nicholls, G. D. Sedimentary geochemistry. A possible future method for correlation of strata: Petroleum [London], v. 21, p. 316-320, 324, 1958.

Trace-element distribution across a basin of deposition in Wales and the Lake District in England was studied. The "green streak," a band $1 / 4$ to 1 in. thick which occurs in the Monograptus leptothea zone of the Silurian black shales, provides excellent fixed stratigraphic control. The $\mathrm{Rb} / \mathrm{Cs}$ ratio was remarkably constant in the streak but higher in the shales above than in those below. The $\mathrm{Zr} / \mathrm{Rb}$ ratio was lower in the center of the basin and the $\mathrm{Co} / \mathrm{Ni}$ ratio also appears to decrease toward the center of the basin of deposition. $\mathrm{Rb} / \mathrm{Cs}$ ratios in the black shales below the green streak in sequence from west to east across the geosyncline are: $21.2,24.5,22.5,21.4,23.3,23.2,25.6,22.7,19.2$; in the black shales above the streak: $24.6,24.9,25.4,26.9,26.7,28.2,19.3,22.5,22.8$.-EBT

00274 Nicholls, G. D.; Loring, D. H. The geochemistry of some British Carboniferous sediments: Geochim. et Cosmochim. Acta, v. 26, p. 181-223, 1962.

Rocks from a drill core through the Coal Measures at Bersham, North Wales, consist chiefly of quartz, illite, and kaolinite, and less amounts of chlorite, organic matter, 
sulfide, and siderite. Trace-element content of detrital minerals was probably augmented by sorption from solution. The chief sorbents are illite, organic matter, and to a lesser extent FeS. The range in element content in the shales is (in ppm): 17-86, Cr 100-190, Cu 18-45, Ga 10-30, Ni 33-138, Pb 3-10, V 90-260, B 50-75, Ba 300-400, Li 50-270, R b 120-170, Sr 35-120, Zr 160-390.-JDV

Nielsen, A. H. See Bøgvad, Richard. 00018

00239 Noddack, Ida. Uber die Allgegenwart der chemischen Elemente [On the omnipresence of the chemical elements (in German)]: Angew. Chemie, v. 49, no. 47, p. $835-841,1936$.

It is suggested that all chemical elements occur in all minerals. A chemical and optical spectrographic analysis of the Kupferschiefer from Mansfeld shows the following element contents (in percent): $\mathrm{O}$ 42, Si 26, Al 9, Ca 6, Mg 4, Fe 4, $\mathrm{Cu} 3, \mathrm{~S} 6, \mathrm{Na} 1.8, \mathrm{~K} \mathrm{0.4}, \mathrm{C} 0.9$, Sr 0.2, Cl 0.6, Ni 0.3, Zn 0.5, Mn 0.2, Ti 0.3, N 0.2, V 0.1; (in ppm): Mo 800, Cr 400, F 200, Sr 400, Ba 200, Zr 200, Co 500, As $900, \mathrm{~Pb} 400$, Se 300, Sn 200, Hf 20, Br 40, Li 20, B 30, Li 8, W 2, Ag 3, Ga 9, Cd 8, Th 8, Ge 8, Bi 5, Pd 2, Te 2, Sb 5, Pt 5, Y 3, La 2, Sc 4, Ru 0.3, Au 0.3 , U 0.2, Be 0.5, In 0.3, TI 0.2. Nb 0.8, Ta 0.6. Re 0.4, Ir 0.04, I 0.04, Os 0.03 , $\mathrm{Rh} 0.02$, and $\mathrm{Hg} 0.02$ [Note: $\mathrm{Sr}$ and $\mathrm{Li}$ are listed twice with different values].EBT

00270 Noll, W. Geochemie des Strontiums (in German): Chemie der Erde, v. 8, no. 4, p. 501600,1934 .

Sedimentary, metamorphic, and igneous rocks and minerals were analyzed spectrographically for $\mathrm{Sr}$. Sr was found to be associated with $\mathrm{Ca}$ in magmatic as well as sedimentary rocks and to be generally associated with $\mathrm{Ba}, \mathrm{Pb}$, and $\mathrm{K}$. The average content of $\mathrm{Sr}$ in shales was found to be $200 \mathrm{ppm}$, probably as a result of colloid chemistry sorption phenomena by clays. Contains an extensive bibliography and a list of age and location data for samples used to make the composite sample of 36 European Paleozoic shales. -EBT

Northcote, K. E. See White, W. H. 0033I

Nuriyev, A. N. See Zul'fugarly, N. D. 00319

00240 Odum, H. T. Biogeochemical deposition of strontium: Inst. Marine Sci. Pub., v. 4 , no. 2 , p. $38-114,1957$.

Sr:Ca ratios of minerals, tissues, skeletons, soils, modern and ancient sediments and sedimentary rocks, and igneous rocks were determined from 900 flame spectrophotometric analyses and compared with data from the literature. Sr:Ca ratios of the resistant and acid insoluble fraction of soils and sediments are higher than the ratios in the calcareous, acid soluble fraction. Replacement in and recrystallization of older materials causes a lower $\mathrm{Sr}$ :Ca ratio, but this ratio increases with decreasing carbonate content. Under specified conditions and in combination with other information, Sr:Ca ratios may indicate replacement, environment of deposition, and food sources in the environment. Sr contents found in shales are (in ppm): Lower Carboniferous, Nova Scotia, 720; Cambrian Burgess Shale, British Columbia, 100, Ordovician Athens Shale, Tenn., 260; Ordovician Utica Shale, N. Y., 120. Devonian Marcellus Shale, Pa., 190, Pennsylvanian Conemaugh Formation, Pa., 660; Recent mud, Buzzards Bay and Hadley Harbor, Mass., 60, 120.—EBT

Olausson, Eric. See Joensuu, Oiva. 00185

00267 Olson, J. C.; Overstreet, W. C. Geologic distribution and resources of thorium: U.S. Geol. Survey Bull. 1204, 61 p., 1964.

Th content of 46 samples of the Chattanooga Shale [of Devonian and Mississippian age], which is abnormally rich in $U$, ranges from 8.1 to $15 \mathrm{ppm}$. U reserves in the Gassaway Member of the Chattanooga Shale have been estimated for an area of about 5,000 square miles; this member contains 7 to $9 \mathrm{ppm}$ Th or about $1,100,000$ tons for the area in which $U$ reserves were estimated.--EBT 
Olson, O. E. See Moxon, A. L. 00154

Olson, O. E. See Moxon, A. L. 00238

Olson, O. E. See Moxon, A. L. 00239

00241 Onishi, Hiroshi. Notes on the geochemistry of germanium (in English): Chem. Soc. Japan Bull., v. 29, no. 6, p. 686-694, 1956.

Average Ge content in the lithosphere (crustal rocks) is $1.5-0.5 \mathrm{ppm}$. Shales and red oceanic clays contain $2 \mathrm{ppm}$ Ge. Ge content of sediments seems to be higher than that of igneous rocks because of possible escape of $\mathrm{Ge}$ in hydrothermal and volcanic emanations. Ge content in 4 Japanese shales ranged from 1.4 to $1.6 \mathrm{ppm}$. In the composite sample of 36 European Paleozoic shales, Ge content is $2.2 \mathrm{ppm}$; in $14 \mathrm{~J}$ apanese Paleozoic shales, $1.6 \mathrm{ppm}$; and in 10 Mesozoic Japanese shales, 1.8 ppm.-Author's summ., modified.

00242 Onishi, Hiroshi; Sandell, E. B. Meteoric and terrestrial abundance of tin: Geochim. et Cosmochim. Acta, v. 12, p. 262-270, 1957.

Ultramafic rocks average approximately $0.5 \mathrm{ppm} \mathrm{Sn}$; mafic rocks, $1.5 \mathrm{ppm}$; and granitic rocks, $3 \mathrm{ppm}$. Sn content of the upper lithosphere is $2 \pm 1 \mathrm{ppm}$, granitic and mafic rocks being weighted equally. In sedimentary rocks, Sn chiefly is found in shales. Too few shales were analyzed in the present work to furnish a reliable average. The average of 36 European Paleozoic shales and 24 Japanese Paleozoic and Mesozoic shales is $4 \mathrm{ppm} \mathrm{Sn.} \mathrm{A} \mathrm{composite} \mathrm{of} 7$ North American shales contained II ppm Sn.-EBT

00268 Onishi, Hiroshi; Sandell, E. B. Geochemistry of arsenic: Geochim. et Cosmochim. Acta, v. 7, p. 1-33, 1955a.

The average value for As in shales probably lies in the range 5-15 ppm. Shales containing much carbonaceous matter or sulfide tend to have more As. Sandstones and limestones normally contain less As than shales; their average is similar to that of igneous rocks, about $2 \mathrm{ppm} \mathrm{As.} \mathrm{Deep-sea} \mathrm{sediments} \mathrm{average} \mathrm{about} 10 \mathrm{ppm}$ As. A reducing environment is favorable for accumulation of As, but, possibly, at very low oxidation potentials $\mathrm{AsH}_{3}$ can form and escape, and micro-organisms can produce volatile organo-arsenic compounds. As content in shales ranges from $0.3 \mathrm{ppm}$ in a vanadiferous shale from the Permian Phosphoria Formation in Idaho to $59 \mathrm{ppm}$ in a Devonian bituminous shale from New York; tasmanite oil shale from Tasmania contains $6.5 \mathrm{ppm}$. The composite of 36 European Paleozoic shales contained $17.7 \mathrm{ppm} \mathrm{As}$ and $4.5 \mathrm{ppm} \mathrm{Mo}$; the 14 Japanese Paleozoic shales, 6.7 ppm As and $2.9 \mathrm{ppm} \mathrm{Mo}$, and the 10 Mesozoic Japanese shales, $5.8 \mathrm{ppm}$ As and $0.5 \mathrm{ppm}$ Mo.-EBT

00269 Onishi, Hiroshi; Sandell, E. B. Notes on the geochemistry of antimony: Geochim. et Cosmochim. Acta, v. 8, p. 213-221, 1955b.

Sb content in igneous rocks (and in the upper lithosphere) is estimated to be $0.1-$ $0.2 \mathrm{ppm}$. In shales, Sb ranges from about 0.1 to several $\mathrm{ppm}$ and averages 1$2 \mathrm{ppm}$. Limestone and sandstone normally contain less $\mathrm{Sb}$ than shales. Oceanic red clay (Pacific Ocean) contains about $1 \mathrm{ppm} \mathrm{Sb}$; globigerina ooze, a few tenths $\mathrm{ppm}$. In shales the following contents of $\mathrm{Sb}$ and $\mathrm{As}$ were found (in ppm): Composite of 3, Wisconsin, 0.1 Sb, 6 As; pyritic shale, Wisconsin, 0.3 Sb, 16.2 As, Decorah Shale (Ordovician), Minnesota, 0.1, 0.3 Sb, 6.9 As; carbonaceous shale, Pennsylvania, $0.3,0.2 \mathrm{Sb}, 6 \mathrm{As}$; bituminous shale, New York, 2.2, $2.5 \mathrm{Sb}, 59 \mathrm{As}$; oil shale (tasmanite), Tasmania, $0.2 \mathrm{Sb}, 6.5 \mathrm{As}$; composite ( 3 calcareous, 1 organic) 2.5, 2.6 Sb, 12.3 As; composite of 3, Japan, 0.4 Sb, 30.5 As; and non-weighted composite of 36 European Paleozoic shales, 14 Japanese Paleozoic shales and 10 Japanese Mesozoic shales, 2.3 Sb, 10.2 As.-EBT

00243 Ostrom, M. E. Trace elements in Illinois Pennsylvanian limestones: Illinois Geol. Survey Circ. 243, 34 p., 1957. 
To study the possibility that agricultural limestone might contain sufficient amounts of trace elements to benefit plants growing in soil to which it has been applied, 92 limestone samples were taken from rock exposed in 35 quarries. Samples of 17 shales associated with the limestones were also taken. Spectrochemical analyses showed that the shales contain more of most trace elements than do the limestones. In the shales the following range of element contents (averages in parentheses) was noted (in ppm): B 40-300 (130), Ba 100-400 (200), Cr 46-180 (110), Cu 60-200 (90), Fe 13,000-60,000 (31,000), K 10,000-22,000 (16,900), Mn tr-600 (300), Mo nd -60 (8), Na 1,800-7,700(4,300), Ni 20-300 (110), Pb 10-400 (140), Sr 120-1,400 (390), Ti $2,100-7,500(4,600)$, v $40-150$ (90), and $\mathrm{Zn}$ nd-400 (160).-Author's abs., modified.

00267 Ostrom, M. E.; Hopkins, M. E.; White, W. A.; McViker, L. D. Uranium in Illinois black shales: Illinois Geol. Survey Circ. 203, 15 p., 1955.

From outcrops in 44 Illinois counties, 175 samples of dark-gray to black shale ranging in age from Devonian to Pennsylvanian were collected. The highest equivalent $U$ content determined by radiometric assay was $170 \mathrm{ppm} . \mathrm{U}_{3} \mathrm{O}_{8}$ content of the 15 samples having the highest equivalent $U$ content ranged from 10 to 140 $\mathrm{ppm}$ and averaged $20 \mathrm{ppm}$ lower than the equivalent $U$ content. Phosphatic nodules and bands found in relatively small quantities in some black shales showed more equivalent $\mathrm{U}$ than the enclosing shales. Maximum $\mathrm{U}_{3} \mathrm{O}_{8}$ content of the phosphatic material was 750 ppm.--Authors' abs., modified.

00244 Ostroyumov, E. A. Redkiye zemli v glubokovodnykh otlozheniyakh Chernogo morya [Rare earths in deep-water deposits of the Black Sea (in Russian)]: Akad. Nauk SSSR Doklady, v. 91, no. 5, p. 1175-1178, 1953.

Sediments from deep-water regions of the eastern part of the Black Sea and the heavy mineral fraction from the sand on the Caucasian coast at Gagra were analyzed for $\mathrm{La}_{2} \mathrm{O}_{3}, \mathrm{CeO}_{2}, \mathrm{Pr}_{2} \mathrm{O}_{3}, \mathrm{Nd}_{2} \mathrm{O}_{3}, \mathrm{Gd}_{2} \mathrm{O}_{3}$, and $\mathrm{Dy}_{2} \mathrm{O}_{3}$. The total rare-earth element contents in the deep-water sediments are as follows (ranges are given in ppm): calcareous mud 130-150, argillaceous-calcareous mud 200, argillaceous-arenaceous mud 340-400, and argillaceous-aleurolitic mud 200-250. The rare earths in the muds consist mainly of $\mathrm{Ce}\left(39.0-47.4\right.$ percent $\left.\mathrm{CeO}_{2}\right)$, $\mathrm{La}\left(21.8-25.2\right.$ percent $\left.\mathrm{La}_{2} \mathrm{O}_{3}\right)$ and $\mathrm{Nd}\left(16.7-24.6\right.$ percent $\left.\mathrm{Nd}_{2} \mathrm{O}_{3}\right)$; in six samples $\mathrm{Ce}>\mathrm{La}>\mathrm{Nd}$ and only in one $\mathrm{Ce}>\mathrm{Nd}>\mathrm{La} .-\mathrm{EBT}$

00245 Ostroyumov, E. A.; Silina, O. M. O nekotorykh zakonomernostyakh raspredeleniya vanadiya $v$ sovremennykh morskikh otlozheniyakh [On some regularities of the distribution of vanadium in modern marine sediments (in Russian)]: Akad. Nauk SSSR Doklady, v. 86, no. 2, p. 365-367, 1952.

$\mathrm{V}$ was determined colorimetrically in 129 samples of bottom sediments of the Okhotsk Sea. The highest concentrations of $\mathrm{V}_{2} \mathrm{O}_{5}(>300 \mathrm{ppm})$ were associated with sediments formed from products of volcanic activity. The lowest concentrations of $\mathrm{V}_{2} \mathrm{O}_{5}(<100 \mathrm{ppm})$ were found in nearshore sandy sediments. Higher contents of $\mathrm{V}_{2} \mathrm{O}_{5}(150-300 \mathrm{ppm})$ were related to very fine argillaceous sediments. $\mathrm{V}$ content is not directly related to organic matter content but the distribution of $\mathrm{V}$ and organic $C$ coincides due to the deposition of organic material with clay minerals. It is suggested that $\mathrm{V}$ is sorbed by clay minerals; no influence of marine animals on the accumulations of $\mathrm{V}$ could be confirmed.--EBT

00246 Ostroyumov, E. A.; Volkov, I. I. K voprosi o vzaimosvyazi fosfora, vanadiya i organicheskogo veshchestva $v$ otlozheniyakh Chernogo Morya [The relationship between phosphorus, vanadium and organic matter in the Black Sea deposits]: Geokhimiya, no. 6, p. 518-528, 1957: English translation: Geochemistry, no. 6, p. 609-619, 1957 [1960]: also Associated Tech. Services, Inc., Translation RJ-1360 [1958].

$\mathrm{P}$ and $\mathrm{V}$ are concentrated primarily with the mineral fraction of sediments of the Black Sea, but in many cases a relation between P, V, and organic matter has been observed. In shallow-water sediments and in upper horizons of deep-sea sediments $P$ is related to organic matter, but during decay of organic matter, $P$ transfers to the mineral fraction of the sediment. In deep-sea sediments $V$ accumulation related 
to increased organic content may be explained by the fact that in bituminization processes $\mathrm{V}$ moves from the mineral matter of the sediment to organic derivitives and in redistribution processes is concentrated in layers enriched in organic material. In 68 samples of various sediment types from 12 stations ranging in depth from 46 to $2,135 \mathrm{~m}$ values range as follows (in percent): $\mathrm{CaCO}_{3} 0-70.57, \mathrm{P}_{2} \mathrm{O}_{5} 0.07$ $0.33, \mathrm{~V}_{2} \mathrm{O}_{5} 0.00-0.045$, organic $\mathrm{C} 0.23-17.36$, mineral residue 22.61-99.15.—Authors' abs., modified.

Overstreet, W. C. See Olson, J. C. 00267

00262 Pachadzhanov, D. N. K geokhimii niobiya i tantala $v$ glinakh [Geochemistry of niobium and tantalum in clays (in Russian; English abs.)]: Geokhimiya no. 10, p. 930-942; English translation: Geochemistry, no. 10, p. 963-976, 1963.

Contents of $\mathrm{Nb}$ average $20.1 \mathrm{ppm}$ in clays formed in humid environments, 13.3 in clays formed under arid conditions, and 18.3 in all clays. Ta averages $2.4 \mathrm{ppm}$ in humid clays, 0.9 in arid clays, and 2 in all clays. $\mathrm{Ta}$ and $\mathrm{Nb}$ substitute for $\mathrm{Ti}$ and $\mathrm{Al}$ in clay minerals. The normal $\mathrm{Ti}: \mathrm{Nb}$ ratio in clays is disturbed by increases in organic $\mathrm{C}$ content, partly because organic matter reduces $\mathrm{Ti}$ and not $\mathrm{Nb}$. This ratio may also be changed by differential adsorption and complexing by organic matter. In Devonian and Carboniferous marine clays from the Russian platform containing $>1$ percent organic $\mathrm{C}$ the following range in contents is observed: Nb 13.1-25.9 ppm, Ta $0.3-2.4 \mathrm{ppm}$, organic C 1.00-6.05 percent, Nb:Ta ratio 5.7-43.6, and $\mathrm{Ti}: \mathrm{Nb}$ ratio $160-479$. - EBT

00263 Pallister, H. D.; Thoenen, J. R. Flake-graphite and vanadium investigation in Clay, Coosa, and Chilton Counties, Alabama: U.S. Bur. Mines Rept. Inv. 4366, 84 p., 1948.

The flake-graphite deposits of Alabama are confined to a narrow belt extending southwestward from northeast Clay County to the edge of the coastal plain, and are near the outcrop of metamorphic rocks of the Precambrian Ashland Series. Flake graphite in commercial quantities occurs only in quartz-mica schist: the best is in schist cut by small pegmatite dikes along planes of schistosity. Heat and pressure from the intrusions may have recrystallized organic $\mathrm{C}$ in the schists to form the graphite and green mica. Green mica comprises 2.2 to 35.5 percent of the rock; by froth flotation methods it is concentrated. This concentrate contains 0.02 to 0.99 percent $\mathrm{V}_{2} \mathrm{O}_{5}$. A typical sample of the concentrate has the following composition (in percent): $\mathrm{Al}_{2} \mathrm{O}_{3} 32.6, \mathrm{~K}_{2} \mathrm{O} 5.6, \mathrm{Fe}_{2} \mathrm{O}_{3} 3.91, \mathrm{TiO}_{2} \quad 0.52, \mathrm{~V}_{2} \mathrm{O}_{5} \quad 0.95$, $\mathrm{SiO}_{2} 45.8$, insoluble 0.99 , loss on ignition 9.63.-EBT

Patterson, C. C. See Chow, T. J. 00066

Payne, K. W. See Hallam, A. 00105

00264 Peltola, Esko. On the black schists in the Outokumpu region in eastern Finland (in English): Finlande Comm. Géol. Bull. 192, 107 p., 1960.

Among the black fine-grained phyllitic to gneissoid schists with sedimentary structure and corresponding most nearly to sapropelic sediments in chemical composition-particularly in trace element composition-argillaceous, calcareous and arenaceous varieties can be distinguished. C content of more than 1 percent and iron sulfides cause the black color. The composition of different varieties depends on factors connected with original sedimentation. Thinness of the layers reflects slow sedimentation. The argillaceous black schists have the following average minor-element contents (in ppm): $\mathrm{TiO}_{2} 8,300, \mathrm{MnO} 400, \mathrm{Cr}_{2} \mathrm{O}_{3} .800, \mathrm{~V}_{2} \mathrm{O}_{5}$ $1,100, \mathrm{U}_{3} \mathrm{O}_{8} 50, \mathrm{Cu} 500$, Ni 400 , Zn 300, Co 200, Pb 50, Mo 140 , C 50,000, S $51,600, \mathrm{Se} \mathrm{13}$, and $\mathrm{Ag} 2$; in the calcareous black schists: $\mathrm{TiO}_{2} 5,900, \mathrm{MnO} 500$, $\mathrm{Cr}_{2} \mathrm{O}_{3} 700, \mathrm{~V}_{2} \mathrm{O}_{5} 1,100, \mathrm{U}_{3} \mathrm{O}_{8} 70, \mathrm{Cu} 600$, Ni 500, $\mathrm{Zn} 400$, Co $100, \mathrm{~Pb} 50$, Mo 180, C 46,500, S 56,100, Se 25, and Ag 2.-Author's abs., modified.

Perezhogin, G. A. See Shcherbakov, YU. G. 00312

Pesko, Lazer’. See Katchenkov, S. M.00193 


\author{
Peters, Cl. See Goldschmidt, V. M. 00087 \\ Peters, Cl. See Goldschmidt, V. M. 00088 \\ Peters, Cl. See Goldschmidt, V. M.00112 \\ Peters, Cl. See Goldschmidt, V. M. 00117 \\ Peters, Cl. See Goldschmidt, V. M. 00118 \\ Peters, Cl. See Goldschmidt, V. M. 00119
}

00265 Pettersson, Hans; Rotschi, Henri. The nickel content of deep-sea deposits: Geochim. et Cosmochim. Acta, v. 2, p. 81-90, 1952.

$\mathrm{Ni}, \mathrm{Mn}$, and Fe present in sediment cores from the central Pacific Ocean have been determined by microchemical methods. $\mathrm{Ni}$ content is high relative to that of continental rocks and sediments. Considerable variations occur in $\mathrm{Ni}$ content with depth below the sediment surface. No correlation with $\mathrm{Fe}$ and $\mathrm{Mn}$ contents is evident except in cases where a change in the rate of sedimentation appears to have affected all three elements in the same way. The abundance of abyssal Ni may be partly derived from cosmic dust; arguments for and against this thesis are presented. $\mathrm{NiO}$ content in the cores ranged from 40 to $560 \mathrm{ppm} ; \mathrm{Fe}_{2} \mathrm{O}_{3}$, from 0.46 to 9.38 percent; and $\mathrm{MnO}_{2}$, from 0.1 to 3.24 percent.-Authors' abs., modified.

00266 Pliler, R.; Adams, J. A. S. The distribution of thorium, uranium, and potassium in the Mancos Shale: Geochim. et Cosmochim. Acta, v. 26, p. 1115-1135, 1962.

More than 135 samples from Colorado, Utah, Arizona, and New Mexico of the Mancos Shale of Late Cretaceous age were analyzed for U, Th, and K by chemical and radiometric means. The Mancos is a soft, dark-gray or nearly black marine carbonaceous shale. Average concentrations found in the samples were $10.2 \mathrm{ppm}$ $T h, 3.7 \mathrm{ppm} U$, and 1.9 percent $\mathrm{K}$ as metal. Average $\mathrm{Th}: \mathrm{U}$ ratio is 3.1. Variations in $T h, U$, and $K$ contents are gradual and take place over large distances. Th, $T h: U$ ratio and $K$ tend to decrease and $U$ tends to increase with distance from the Upper Cretaceous shoreline. K:Th ratio in the shale, including many sandy intertongues, shows remarkably little variation regionally. The $U$ in the Mancos Shale is present largely in the fine-grained primary resistate minerals; the Th occurs in the fine-grained secondary resistates or fixed in or on clays.-Authors' abs., modified.

00247 Ponsford, D. R. A. Radioactivity studies of some British sedimentary rocks: Great Britain Geol. Survey Bull. 10, p. 24-44, 1955.

$\mathrm{U}_{3} \mathrm{O}_{8}$ was determined chemically and $\mathrm{eU}_{3} \mathrm{O}_{8}$ radiometrically in the British sedimentary sequence. The highest $U$ contents are found in certain black shales in the Upper Cambrian (14-46 ppm $\mathrm{U}_{3} \mathrm{O}_{8}, 12-15 \mathrm{ppm} \mathrm{Th}$ ), Upper Ordovician (26$47 \mathrm{ppm} \mathrm{U}_{3} \mathrm{O}_{8}$ ), Lower Carboniferous ( $30-90 \mathrm{ppm} \mathrm{eU}_{3} \mathrm{O}_{8}$ ), and Upper Carboniferous (50-420 ppm eU $\mathrm{O}_{3}$, Phosphatic black shale, 0.1 percent $\mathrm{U}_{3} \mathrm{O}_{8}, 23.9$ percent $\mathrm{PO}_{4}$ ): in black nodules present in New Red Sandtone strata; and in phosphatic beds of various ages. One specimen of hard black bituminous and slightly phosphatic shaly

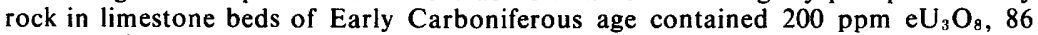
percent ash, and $300 \mathrm{ppm} V$ in ash.-EBT

00260 Porrenga, D. H. Bor in Sedimenten als Indiz für den Salinitätsgrad [Boron in sediments as an index of salinity (in German; English abs.)]: Fortschr. Geologie Rheinland u. Westfalen, v. 10, p. 267-270, 1963.

The amount of B in the clay fraction of 70 reference samples has been determined. The results permit the conclusion that $B$ in sediments can be used as a discriminator between marine and nonmarine sediments, at least on a local scale. B content in the clay fraction of marine sediments of Carboniferous age was $135 \mathrm{ppm}$; in fresh water sediments of Carboniferous age the B content was 80 ppm.-Author's abs., modified. 
00261 Potter, P. E.; Shimp, N. E.; Witters, J. Trace elements in marine and freshwater argillaceous sediments: Geochim. et Cosmochim. Acta, v. 27, p. 669-694, 1963.

Trace elements were studied in 66 samples of modern and ancient marine and freshwater argillaceous sediments to test for environmental indicators. Samples were widely scattered geographically and represent varying source areas, climates, tectonic conditions, and rates of sedimentation. $\mathrm{B}, \mathrm{Cr}, \mathrm{Cu}, \mathrm{Ga}, \mathrm{Ni}$, and $\mathrm{V}$ are significantly more abundant in marine than in fresh-water sediments. Samples were analyzed by 2 quantitative spectrographic methods; coefficients of variation ranged from \pm 5 percent for $\mathrm{V}$ and $\mathrm{Ga}$ to \pm 30 percent for $\mathrm{Cu}$. Average trace-element content in modern marine sediments was (in ppm): B $89.6, \mathrm{Cr} 66, \mathrm{Cu} \mathrm{37.3,} \mathrm{Ga} 20$, Ni 40.7, $\mathrm{Pb} 20.8, \mathrm{~V}$ 125.5, Co nd-14, $\mathrm{Zn}$ nd-4,500; in ancient (Ordovician to Cretaceous) marine sediments: B 123.6, Cr 91.9, Cu 28.2, Ga 25.3, Ni 41.8, Pb 13.3, V 118.2, Co nd-43, $\mathrm{Zn}$ nd [range quoted for $\mathrm{Co}$ and $\mathrm{Zn}$ ].-Author's abs., modified.

00256 Prashnowsky, A. A. Sedimentpetrographische und geochemische Untersuchungen im sudlichen Rheinischen Schiefergebirge [Sedimentary petrographic and geochemical study in the southern Rhine shale area (in German)]: Neues Jahrb. Geologie u. Paläontologie Abh., v. 105, no. 1, p. 47-70, 1957.

Geochemical and heavy-mineral analyses were conducted on sediments of preDevonian age in the southern Rhine shale area near Ems. The heavy mineral analyses were of a pre-Devonian quartzite. In addition to the quartzite, shale, limestone, diabase, keratophyre, and metamorphic rocks were analyzed spectrographically. Qualitative and, in part, semiquantitative analyses for 26 elements are presented in tables. Table 5 shows the average contents of trace elements in different rocks. Four samples of black shale of Devonian age from Kaup contained (in ppm) these averages: Ba 900, Sr 290, Cu 50, Ni 40, Co 60, Cr 700, V 200, Mn 2,500, Ti 5,300, Mo tr, and Pb tr.--EBT

00257 Preuss, E. Beiträge zur spektralanalytischen Methodik. II. Bestimmung von $\mathrm{Zn}, \mathrm{Cd}, \mathrm{Hg}, \mathrm{In}, \mathrm{Tl}, \mathrm{Ge}, \mathrm{Sn}, \mathrm{Pb}, \mathrm{Sb}$, and $\mathrm{Bi}$ durch fraktionierte Distillation [Contribution to the spectroanalytical method. II. Determination of $\mathrm{Zn}, \mathrm{Cd}, \mathrm{Hg}$, $\mathrm{In}, \mathrm{Tl}, \mathrm{Ge}, \mathrm{Sn}, \mathrm{Pb}, \mathrm{Sb}$, and $\mathrm{Bi}$ through fractional distillation (in German)]: Zeitschr. angew. Mineralogie, v. 3, p. 8-20, 1941.

A method of spectral analysis is described and discussed. The mean of analyses of the composite sample of 36 European Paleozoic shales is (in ppm): $\mathrm{Cd} 0.3$, $\mathrm{Hg} \mathrm{0.3,} \mathrm{In} \mathrm{0.5,} \mathrm{Tl} \mathrm{2,} \mathrm{Ge} \mathrm{7,} \mathrm{Sb} \mathrm{3,} \mathrm{and} \mathrm{Bi} \mathrm{1.-EBT}$

00257 Pryakhina, YU. A. Karbonatnye konkretsii v maykopskikh otlozheniyakh tsentral'nogo Predkavkaz'ya [Carbonate concretions in the Maikopian deposits of the central Fore-Caucasus]: Akad. Nauk SSSR, Izv. Ser. Geol., no. 1, p. 26-42, 1958a: English translation: Am. Geol. Inst., p. 18-31, 1959.

Carbonate concretions, particularly sideritic concretions, are distributed throughout Carboniferous to Recent formations. Siderites and other carbonate concretions from the Maikop Series [of Eocene and Oligocene age] in central Fore-Caucasus are diagenetic, gray, dark gray, greenish gray, and black like the enclosing argillaceous rocks. The presence of organic matter (bitumens, carbonacenis fíagments), pyrite, and siderite indicates a reducing environment. Contents of trace elements in Maikopian clays showed the following ranges (in ppm): $\mathrm{Cu} 50-60, \mathrm{Cr} 100, \mathrm{Ni}$ 66-80, Co 10-20, V 140-200, Sr 100-300, Be 2-7, Mo 1-100 [This same table is in Pryakhina (1958b, p. 133) and shows Mo maximum content $10 \mathrm{ppm}]$, Ga 2100.-EBT

00258 Pryakhina, YU. A. K geokhimii maykopskikh otlozheniy Tsentral'nogo Predkavkaz'ya [On the geochemistry of the Maikopian deposits of the central ForeCaucasus]: Akad. Nauk SSSR Doklady, v. 118, p. 132-134, 1958b; English translation: New York, Consultants Bur., Inc., p. 1-3.

The Maikopian rocks [of Eocene and Oligocene age] in the central Fore-Caucasian area consist of a uniform thick sequence of dark marine clays with seams and layers of sand and sandstone. In clays the element contents are (in ppm): $\mathrm{Fe} 55,000$, 
Mn 400, P 300, Cu 60, Cr 100, Ni 80, Co 10, V 200, Ba 700, Sr 300, Ga 100, $\mathrm{Be} 7$, and Mo 4. Organic C content ranges from 0.2 to 4 percent. Several horizons of black "sooty" clays are found. In these the element contents are (in ppm): $\mathrm{Ni} 462$, Co 44, $\mathrm{Zn} 820, \mathrm{~Pb} 450, \mathrm{Mo} 200, \mathrm{Cu} 46, \mathrm{~V} 106, \mathrm{Cr}$ ?, organic C 0.950 percent, and pyrite 13 percent; element contents in clays enclosing the sooty horizon are: $\mathrm{Ni} 52, \mathrm{Co} 14, \mathrm{Zn} \mathrm{1,} \mathrm{Pb} \mathrm{1,} \mathrm{Mo} \mathrm{1,} \mathrm{Cu} \mathrm{51,} \mathrm{V} \mathrm{162,} \mathrm{C} 111$, organic C 1.450 percent, and pyrite 1.31 percent.--EBT

00259 Pushkina, Z. V. K geokhimii Usinskogo margantsovogo mestorozheniya [The geochemistry of the Usinsk manganese deposit]: Akad. Nauk SSSR Doklady, v. 135, no. 1, p. 176-178, 1960; English translation: New York, Consultants Bur. Inc., p. 1071-1073, 1961.

The distribution of $\mathrm{Cu}, \mathrm{Ni}, \mathrm{Co}, \mathrm{V}$, and $\mathrm{Cr}$ in various types of manganese ores and adjoining rocks of the Usinsk manganese deposit on the western flank of Kuznetsk Ala-Tua in Kemerovo Oblast was studied. The manganese ore deposit is of Early Cambrian age and of sedimentary origin. Lime-rhodochrosite and manganese limestones are interbedded with light metamorphosed and dark pelitomorphic limestones and clay slates of varying degrees of metamorphism. Analyses show increased $\mathrm{V}$ and $\mathrm{Cr}$ contents in the slates and slightly increased $\mathrm{Cu}$ and $\mathrm{Ni}$. In calcareous and carbonaceous slates the following contents were found (ranges in

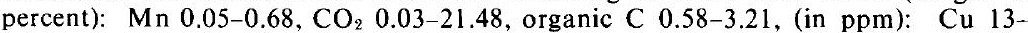
91, Ni 14-123, Co 12-70, V 110-253, and Cr 31-69.-EBT

00248 Rader, L. F.; Grimaldi, F. S. Chemical analyses for selected minor elements in Pierre Shale: U.S. Geol. Survey Prof. Paper 391-A, 45 p., 1961.

The analytical precision of chemical methods for determination of selected mino elements in the Cretaceous Pierre Shale is reported. Detailed procedures for determination of Ti, V, Cr, Mn, Co, Ni, Cu, Zn, Pb, As, Se, Mo, W, U, carbonate $C$, total $C$, and organic matter are described and some alternative methods are given Precision of analytical methods is established from replicate determinations by one chemist on paired hidden splits, replicate determinations on different days by one chemist, and cross-check determinations on 10 selected samples by differen chemists, laboratories, and methods. Graphic comparisons are made of determinations by different chemists, and the mean element content and standarc deviations, calculated from data reported by all analysts and laboratories, of the 10 check samples are reported. In the 10 samples, the mean determinations of organie $C$ ranged from $<0.2$ to 8.4 percent, of minor elements (in ppm), Ti $1,400-4,400$ Mn 80-35,000, V 20-800, Cr <4-150, Co 4-21, Ni 14-140, Cu 5-71, Zn 45-300 $\mathrm{Pb}$ 15-36, As 2-48, Se <1-110, Mo <1-340, U 1.3-25.--Authors' abs., modified.

Rader, L. F. See Tourtelot, H. A. 00282

Ramsey, V. G. See Erdman, J. G. 00045

00253 Rankama, Kalervo. On the geochemistry of tantalum: Finlande Comm. Géol Bull. 133, 78 p., 1944.

Ta is a quite mobile element, largely participating in pneumatolytic processes. T. is strongly lithophile and has no siderophile or chalcophile features in it geochemistry. Average Ta content in igneous rocks is $2.1 \mathrm{ppm}$ and the $\mathrm{Nb}: \mathrm{Ta}$ ratio is 9.5. The maximum possible average content of $\mathrm{Ta}_{2} \mathrm{O}_{5}$ in investigated sediment is $1.7 \mathrm{ppm}$; in deep-sea sediments it is $1.2 \mathrm{ppm}$. In some black shales the $\mathrm{Ta}_{2} \mathrm{O}$ contents are (in ppm): Dictyonema shale, Estonia, 2; Liassic paper shale, Bavaria $<0.6$; Kupferschiefer, Thuringia, <1; Upper Cambrian Alum shale, Norway, 4 Liassic calcareous Posidonia shale, Germany, <0.7.-EBT

00254 Rankama, Kalervo. The geochemistry of columbium: Science, v. 106, p. 13 15, 1947.

$\mathrm{Cb}$ [now called niobium] contents were determined by spectrochemical analysis $\mathrm{i}$ the Geochemical Laboratory, Institute of Geology, University of Helsinki, Finlanc $\mathrm{Cb}$ is more common in sedimentary rocks and igneous rocks than is $\mathrm{Ta}$. Th following contents of $\mathrm{Cb}_{2} \mathrm{O}_{5}$ were found in sediments (in ppm): minerogeni 
sediments, 18; chemical sediments, 0.6; organogenic sediments, 0.9; deep-sea sediments, 59....EBT

00255 Rankama, Kalervo; Sahama, Th. G. Geochemistry: Chicago, University of Chicago Press, 912 p., 1950.

An extensive bibliography is contained and many data pertinent to black shales are quoted. The average composition of shale as compiled by the authors is (in ppm): Li 46, Be <3.6, B 310, C 15,300, F 510, Na 9,700, Mg 14,800, Al 81,900, Si $272,000, \mathrm{P} 740, \mathrm{~S} 2,600, \mathrm{Cl}--$, K 27,000, Ca 22,300, Sc 6.5, Ti 4,300, V 120 , Cr 410-680, Mn 620, Fe 47,300, Co 8, Ni 24, Cu 192, Zn 200-1,000, Ga 50, Ge 7. As $\sim 5, \mathrm{Se} 0.6, \mathrm{Br}>0.2, \mathrm{Rb} 300, \mathrm{Sr} 170, \mathrm{Y} 28.1, \mathrm{Zr} 120, \mathrm{Ag} \mathrm{0.05,} \mathrm{Cd} \mathrm{0.3,} \mathrm{In}$ 0.5 , Sn 40, Sb 3, I --, Cs 12, Ba 460, W 1-2, Re $<0.001, \mathrm{Au}--, \mathrm{Hg} 0.3, \mathrm{Tl} 2$, $\mathrm{Pb} 20$, Bi 1, Ra $1.08 \times 10^{-6}$, Th 10.1, U 1.2.- EBT

00249 Razumnaya, E. G. Izucheniye raspredeleniya molibdena i vanadiya $v$ uglistokremnistykh slantsakh metodom tsentrifugirovaniya [Study of the distribution of molybdenum and vanadium in carbonaceous siliceous shales by centrifuge methods (in Russian)]: Sovrem. Metody Mineralog. Issledov. Gornykh Porod Rud i Mineralov, p. 49-54, 1957.

A carbonaceous siliceous (radiolarian) shale containing humic organic matter (about 10 percent organic $\mathrm{C}$ ), 0.2 percent $\mathrm{V}, 0.1 \mathrm{Cr}$ and $\mathrm{Ba}, 0.03 \mathrm{Mo}$, and about $0.01 \mathrm{Ni}$, $\mathrm{Zn}, \mathrm{Cu}$, and $\mathrm{Pb}$ was centrifuged in heavy liquids into 7 fractions whose specific gravity ranged from 2.1 to 2.8 . Mo and $V$ are concentrated in the heaviest fraction which contains red and yellow oxides and hydroxides of $\mathrm{Fe}$, and may be sorbed on these oxides. Lesser concentrations of Mo and V occur in the lightest fractions which are predominantly organic matter; probably 60 percent of the Mo and 30 percent of the $\mathrm{V}$ is bound with the organic matter. In the specific gravity fractions (listed first) the following percentages of Mo and $V$ were found: $<2.1,0.094 \mathrm{Mo}$, $0.34 \mathrm{~V} ; 2.1-2.4,0.68 \mathrm{Mo}, 0.23 \mathrm{~V} ; 2.4-2.5,0.29 \mathrm{Mo}, 0.186 \mathrm{~V} ; 2.5-2.6,0.035 \mathrm{Mo}$, $0.44 \mathrm{~V} ; 2.6-2.7,0.43 \mathrm{Mo}, 0.41 \mathrm{~V} ; 2.7-2.8,0.19 \mathrm{Mo}, 1.14 \mathrm{~V}$; >2.8, spectrographic analysis shows near $1 \mathrm{~V}$, near 0.1 Mo.-EBT

Reznikov, A. P. See Aleksandrov, A. P. 00019

Richardson, E. S., Jr. See Zangerl, Rainer. 00318

00250 Richter, Gerhard. Geologische Gesetzmässigkeiten in der Metalliführung des Kupferschiefers [Geological laws in the mineralization of the Kupferschiefer (in German)]: Arkiv Lagerstättenf., no. 73, 61 p., 1941.

Differences in mineralization in the Permian Kupferschiefer (including the Zechstein conglomerate) are facies phenomena and as such are subject to geological laws. Copper ores are found predominantly in narrow sinuous marginal minor trough deposits whereas sediments deposited in the main basin deeps show only minor metal contents. High copper contents outline the paleogeographic trough; in the flatter part of the trough the zinc facies has prevailed since the beginning of Zechstein time. In the Kupferschiefer sea, rock facies was largely independent of depth of the area of deposition, whereas the metal facies has to be considered as a function of basin depth. The origin of the metals was in metal-rich ground waters that mixed with the basin water.-EBT

00251 Richter-Bernburg, Gerhard. Zwei Beiträge zu Fazies, Tektonik und Kupferführung des Zechsteins. I. Waldeck, II. Nordsudeten [Two studies of the facies, tectonics, and copper content of the Zechstein-1. Waldeck, 2. northern Sudeten (in German)]: Geol. Jahrb. 1949, v. 65, p. 145-212, 1951.

The stratigraphy and paleogeography of the Zechstein sea are discussed. The contents of $\mathrm{Cu}, \mathrm{Pb}$, and $\mathrm{Zn}$ in many samples taken from the lower Zechstein, including the Kupferschiefer, the underlying basal conglomerate, and the overlying bituminous limestone, are given. The highest $\mathrm{Cu}$ contents (as much as $60 \mathrm{~kg}$ per sq $\mathrm{m}$ ) occur in rocks deposited in nearshore embayments.- JDV 
Riley, J. P. See Burton, J. D. 00070

Riley, J. P. See Mullin, J. B. 00152

Riley, J. P. See Wakeel, S. K. El. 00342

Rodionova, K. F. See Strakhov, H. M.00291

Ronov, A. B. See Baranov, V. I. 00009

Ronov, A. B. See Balashov, Yu. A. 00024

00252 Ronov, A. B.; Malyuga, D. P.; Makarova, A. I. Raspredeleniye malykh kolichestv nikelya, kobalita i medi v glinakh russkoy platformy [Distribution of small amounts of nickel, cobalt, and copper in clays of the Russian platform (in Russian)]: Akad. Nauk SSSR Doklady, v. 105, no. 1, p. 129-132, 1955.

Composite samples (117) of clays from the Russian platform ranging in age from Precambrian to Quaternary were analyzed for $\mathrm{Ni}, \mathrm{Co}$, and $\mathrm{Cu}$. Probably the $\mathrm{Ni}$, $\mathrm{Co}$, and a considerable part of the $\mathrm{Cu}$ is carried to the pelagic part of the depositional basin sorbed on the argillaceous fraction. However, a part of the $\mathrm{Cu}$ is carried in solution and precipitates in the zone of mixing of acid continental water with weakly alkaline water in the nearshore deltaic area of the marine basin. The $\mathrm{Cu}$ then is adsorbed by organic matter and deposited in the nearshore sediments. The ratios of $\mathrm{Ni}, \mathrm{Co}$, and $\mathrm{Cu}$ in the sediments suggests information about source areas. In the clays from the Russian platform the Ni:Co ratio fluctuated from 0.7 to 3.8 and the average was 2.0 . The average $\mathrm{Ni}$ content in the clays was $22 \mathrm{ppm}$; Co, $11 \mathrm{ppm}$; and $\mathrm{Cu}, 35 \mathrm{ppm}$.- EBT

Ronov, A. B. See Vinogradov, A. P. 00327

00225 Rösler, H. J. Eine Vererzung vom Kupferschiefertyp im Rotliegenden Thuringens [A mineralization of the copper shale type in the Thuringian Rotliegende (in German)]: Geol. Gesell Berlin, v. 9, no. 2, p. 217-226, 1964.

The mineralization occurs in black, thinly foliated shale and shale striated with fine sand, mostly in the form of flattened concretions. The principal minerals, which are tennantite, arsenopyrite, and pyrite, seem to be associated with coprolites. The kidney-shaped ore contains $\mathrm{Fe}^{2}, \mathrm{Ca}, \mathrm{Mg}, \mathrm{S}, \mathrm{As}, \mathrm{Cu}, \mathrm{PO}_{4}, \mathrm{SiO}_{2}$, and $\mathrm{CO}_{2}$. The As content is as much as 2 to 3 percent. The ore kidney shales are a good example of the importance of biogenetic products of geochemical concentration processes. The Rotliegende is Early Permian in age.-EBT

Rotschi, Henri. See Pettersson, Hans. 00265

00226 Rubey, W. W. Vanadiferous shale in the Phosphoria Formation, Wyoming and Idaho [abs.]: Econ. Geology, v. 38, no. 1, p. 87, 1943.

The presence of small amounts of $\mathrm{V}$ in western phosphate rock has been known since 1911. The region is mountainous and the sedimentary rocks have been intensely deformed and broken by thrust and normal faults. The highest concentrations of $\mathrm{V}\left(0.5\right.$ to 2.0 percent $\left.\mathrm{V}_{2} \mathrm{O}_{5}\right)$ are found in carbonaceous and graphitic (?) mudstone. Throughout most of the region $\mathrm{V}$ occurs principally in a single bed about 3 feet thick. Estimates indicate the presence of many million tons of rock that contain 0.75 percent or more $\mathrm{V}_{2} \mathrm{O}_{5}$.-Author's abs., condensed.

00227 Runnels, R. T. Preliminary report on phosphate-bearing shales in eastern Kansas: Kansas Geol. Survey Bull. 82, pt. 2, p. 37-48, 1949.

Phosphate--bearing bituminous shales of Pennsylvanian age from Crawford, Bourbon, Franklin, Labette, and Wyandotte Counties, Kans., were sampled and analyzed chemically. Special analyses included percent $\mathrm{P}_{2} \mathrm{O}_{5}$ soluble in citric acid, spectrographic analyses for trace elements, and tests for the solubility in water of the trace elements present. These analyses suggest sufficient phosphate and traceelement content to merit evaluation as a source of agricultural fertilizer. Total $\mathrm{P}_{2} \mathrm{O}_{5}$ 
content ranges from 0.81 to 3.76 percent. Qualitative spectrographic analyses showed the following range of trace-element content (ns, not seen; 10, strongest; 5 , trace; 1 , very weak; numbers refer to spectral line intensity; they cannot be compared between elements): $\mathrm{P}$ ns-9, B ns-6, Si 8-9, Mn 4-10, Cr 3-9, Mo ns7, Fe 7-9, Al 6-10, Zr ns-8, Ti 7-10, V 6-10, Cu 6-9, Ag ns-6, Zn ns-6, Pb ns$7, \mathrm{~K} \mathrm{5-8,} \mathrm{Na} \mathrm{6-7,} \mathrm{Ca} \mathrm{5-9,} \mathrm{Mg} \mathrm{7-9,} \mathrm{Sr} \mathrm{ns.-Author's} \mathrm{abs.,} \mathrm{modified.}$

00228 Rynninger, Roland. Mode of occurrence of uranium in Swedish black shales. Preliminary investigations (in English): Geol. Fören. Stockholm Förh., v. 79, p. $88-90,1957$.

Primary experiments on the black (alum) shales of Sweden indicate that 70-80 percent of the $U$ in black shales is soluble in acids and is present along with several other micro elements, $\mathrm{Fe}$, and $\mathrm{Al}$ as a separate fine-grained phase, possibly amorphous, and without structural relation to the major part of the organic constituents as well as the major minerals of the shale. The remaining $20-30$ percent of the $U$ content is possibly contained in some micaceous minerals and is therefore slightly attacked by acids.-EBT

00229 Sahama, Th. G. Spurenelemente der Festeine im Südlichen Finnisch-Lappland [Trace elements in rocks from southern Finnish Lapland (in German)]: Finlande Comm. Géol. Bull. 135, 86 p., 1945.

Rocks from southern Finnish Lapland were analyzed to explore geochemical behavior of trace elements, especially with increasing metamorphism. Processes deduced from existing [pre-1945] data for single trace elements are almost completely valid for the different series studied in Finland. Analyses of Lapponium black schists of Precambrian age showed the following averages (in ppm): 80 samples of ilmenite and carbonate containing schist, Sodankylä, $\mathrm{ZrO}_{2} 0, \mathrm{MnO} 1,500$, $\mathrm{BaO} 300, \mathrm{SrO} 0, \mathrm{La}_{2} \mathrm{O}_{3} 10, \mathrm{CeO}_{2} 40, \mathrm{Nd}_{2} \mathrm{O}_{3} 30, \mathrm{Y}_{2} \mathrm{O}_{3} 0, \mathrm{Sc}_{2} \mathrm{O}_{3} 10, \mathrm{~B}_{2} \mathrm{O}_{3} 60, \mathrm{Rb}_{2} \mathrm{O}_{3}$ $500, \mathrm{Li}_{2} \mathrm{O}_{3} 50, \mathrm{Cr}_{2} \mathrm{O} 1,000, \mathrm{~V}_{2} \mathrm{O}_{5} 100, \mathrm{NiO} 10$, CoO 10; 68 samples of schist between pyrite-bearing layers, Sodankylä, $\mathrm{ZrO}_{2} 0, \mathrm{MnO} 200, \mathrm{BaO} 700, \mathrm{SrO} 30, \mathrm{La}_{2} \mathrm{O}_{3} 10$, $\mathrm{CeO}_{2} 0, \mathrm{Nd}_{2} \mathrm{O}_{3} 0, \mathrm{Y}_{2} \mathrm{O}_{3} 0, \mathrm{Sc}_{2} \mathrm{O}_{3} 1, \mathrm{~B}_{2} \mathrm{O}_{3} 1,000, \mathrm{Rb}_{2} \mathrm{O}_{3} 300, \mathrm{Li}_{2} \mathrm{O} \quad 30, \mathrm{Cr}_{2} \mathrm{O} \quad 1,000$ $\mathrm{V}_{2} \mathrm{O}_{5} 100, \mathrm{NiO} 100, \mathrm{CoO} 30 ; 532$ samples of black phyllite, Kittilä, $\mathrm{ZrO}_{2} 100$, MnO $1,800, \mathrm{BaO} 500, \mathrm{SrO} 60, \mathrm{La}_{2} \mathrm{O}_{3} 60, \mathrm{CeO}_{2} 60, \mathrm{Nd}_{2} \mathrm{O}_{3} 30, \mathrm{Y}_{2} \mathrm{O}_{3} 30, \mathrm{Sc}_{2} \mathrm{O}_{3} 60, \mathrm{~B}_{2} \mathrm{O}_{3}$ $100, \mathrm{Rb}_{2} \mathrm{O}_{3} 800, \mathrm{Li}_{2} \mathrm{O} 30, \mathrm{Cr}_{2} \mathrm{O} 300, \mathrm{~V}_{2} \mathrm{O}_{5} 60, \mathrm{NiO} 30, \mathrm{CoO} 30$.-EBT

Sahama, Th. G. See Rankama, Kalervo. 00255

Saldan, M. See Kita-Badak, M. 00214

Sandals, K. M. See Moxon, A. L. 00154

Sandell, E. B. See Kuroda, P. K. 00200

Sandell, E. B. See Onishi, Hiroshi. 00242

Sandell, E. B. See Onishi, Hiroshi. 00268

Sandell, E. B. See Onishi, Hiroshi. 00269

00230 Sargent, J. D. Selenium data: U.S. Bur. Mines Inf. Circ. 7715, 29 p., 1955.

Physical and chemical properties, geographical distribution, production, consumption, metallurgy, and usage of Se are described. Se content of igneous rocks is about $0.09 \mathrm{ppm}$. Cores of marine sediments from the continental shelf average 1 to $2 \mathrm{ppm} \mathrm{Se}$; deep-sea cores average much less. Contents of the continental shelf deposits correspond closely with those of sedimentary rock strata of the western United States and of the soils derived from them. Limonitic concretions from the Cretaceous Niobrara Formation contain from 20 to more than $500 \mathrm{ppm} \mathrm{Se}$, whereas the surrounding shales contain only $2 \mathrm{ppm}$. Phosphate rock from the Permian Phosphoria Formation of western Wyoming contains from 1 to $600 \mathrm{ppm}$. Other seleniferous formations are listed.-EBT 
Saukov, A. A. See Borisenko, L. A. 00033

00231 Saukov, A. A. Geokhimiya rtuti [Geochemistry of mercury]: Akad. Nauk SSSR, Inst. Geol. Nauk, Trudy, v. 78, Mineralog. i Geokhim. ser. 17, 129 p., 1946; English translation: I. J. Mitten, written commun., 1965.

The geochemistry of $\mathrm{Hg}$ is discussed. Data on $\mathrm{Hg}$ in shales were available from Germany, Sweden, the Caucasus, Tadzhikistan, and the Altai Mountains. Enrichment of $\mathrm{Hg}$ in shales was observed, though the data available were not sufficient to calculate the clarke of $\mathrm{Hg}$ for shales. Theoretically, $\mathrm{Hg}$ content in shales should be about $0.16 \mathrm{ppm}$, or about 2 times the average for effusive rocks; average content in shales was actually found to be $0.153 \mathrm{ppm}$. Data for calculating the average in shales were from Stock and Cucuel (1934) and the following: 11 samples of Lias shales, Caucasus, $0.116 ; 12$ samples of phyllitic shales, Caucasus, 0.108; carbonaceous shales from Tadzhikistan, 0.17; Permian and Carboniferous carbonaceous shales, Altai Mountains, 0.148, Lower Devonian clay shales, Altai Mountains, 0.14; and Cambrian shales, Altai Mountains, $0.076 \mathrm{ppm}$.-EBT

00232 Savul, Mircea; Botez-Postelnicu, Cornelia. Geochimia vanadiului in Republica Populara Romana. II. Seria sisturilor negre bituminoase, roce mume de petrol, din Carpatii Orientali [Geochemistry of vanadium in the Rumanian Peoples Republic. 2. The series of black bituminous shales, the mother-rock of petroleum, in the eastern Carpathiana (in Rumanian; French summ.)]: Acad. Rep. Pop. Romîne, Secţ. Ştiinţe Geol., Geog., Biol., Analele, ser. A, v. 2, mem. 30, 23 p., 1949.

The principal mother rocks of petroleum in Sipote, Rumania, are black shales of Cretaceous age and grit and red shales. The black shales range from argillaceous siliceous to marly siliceous; part of the silica is of biogenic origin. These sediments were deposited in a reducing medium and contain much sapropelic substance. The concentration of $\mathrm{V}$ was favored by the presence of $\mathrm{Fe}^{+3}$ ions and also perhaps by the presence of $\mathrm{Al}^{+3}$ ions. Clays adsorbed the $\mathrm{V}$ during the elimination of free bituminous substances and the retention of nonfree parts. $V$ contents ranged from 412 to $442 \mathrm{ppm}$ in the finely laminated shales.-EBT

00233 Savul, Mircea; Botez-Postelnicu, Cornelia; Jeanrenaud, P.; Ionesi, L. Geochimia elementelor minore $\mathrm{Cu}, \mathrm{Pb}, \mathrm{Zn}$, din flişul paleogen in facies de Tarcau şi FusaruValea Tarcăului (Carpaţii Orientali) [Geochemistry of the minor elements, $\mathrm{Cu}, \mathrm{Pb}$, $\mathrm{Zn}$, in the Paleogene flysch in the facies of Tarcau and Fusaru-Valea Tarcaului (the Oriental Carpathians) (in Rumanian; Russian and French summ.)]: Acad. Rep. Pop. Romine, Filiala Iaşi, Studii Cercatări Ştiinţ. Chimie, v. 9, no. 1, p. 57-81, 1959.

Analyses were made of 40 samples from 8 horizons of the Paleogene flysch series, and geochemical sections of $\mathrm{Cu}, \mathrm{Pb}$, and $\mathrm{Zn}$ were developed. Average contents of minor elements in different rocks exceeded clarke contents for these rocks. In clayey rocks the average contents were (in ppm): $\mathrm{Cu} \mathrm{67,} \mathrm{Zn} \mathrm{52,} \mathrm{Pb} 24$; in bituminous marl, $\mathrm{Cu} 119$. The average content of these minor elements increases through the series psephite, arenite, pelite; this reflects the effect of adsorption. Histograms for each rock type show, in most cases, log normal distribution; the limits of variation of contents distinguish each rock type. Variations in the ratio $\mathrm{Cu}: \mathrm{Pb}: \mathrm{Zn}$ reflect the mobility of $\mathrm{Cu}$ in comparison with $\mathrm{Zn}$ and $\mathrm{Pb}$.--Referativnyy Zhur., 1959 , no. 11 , abs. 23091 , modified.

00234 Savul, Mircea; Movileanu, Aurelia. Cobaltul şi nichelul ca elemente-urmă in rocile carbonatate triasice din Dobrogea de nord [Cobalt and nickel as trace elements in Triassic carbonaceous rocks in northern Dobrudja (in Rumanian; summ. in Russian and French)]: Acad. Rep. Pop. Romine, Filiala Iaşi, Studii Cercatări Ştiinţ Chimie, v. 12, no. 1, p. 45-68, 1961.

The content of Co $(0.3-12.2 \mathrm{ppm})$ in the studied rocks increases with an increase of clay and $\mathrm{Fe}_{2} \mathrm{O}_{3}$. The role of live plants and animals in the concentration of Co is minimal. Ni content ranges from 0.6 to $31.4 \mathrm{ppm}$. The average Ni:Co ratio is 4.42 .- Referativnyy Zhur., 1962, abs. $12 \mathrm{~V} 34$. 
00235 Schneiderhöhn, H. Das Vorkommen von Titan, Vanadium, Chrom, Molybdän, Nickel und einigen anderen Spurenmetallen in deutschen Sedimentgesteinen [The occurrence of titanium, vanadium, chromium, molybdenum, nickel, and some other trace metals in German sedimentary rocks (in German)]: Neues Jahrb. Mineralogie, Geologie u. Paläontologie, Monatsh., Abt. A., no. 1-3, p. 50-72, 1949.

From 1936 to 1944 the Mineralogic Institute of the University of Freiburg made almost 10,000 spectrographic analyses (to within $\pm 10-20$ percent of the value stated) of almost 1,000 samples of German sedimentary rocks ranging in age from Silurian to Miocene. $\mathrm{Ti}, \mathrm{V}, \mathrm{Cr}, \mathrm{Mo}, \mathrm{Mn}$, and $\mathrm{Ni}$ contents were studied in most detail, but crystal chemistry, lithogenesis, facies, and paleogeography were also examined. Mean values for these trace elements in rock groups which contain black shale are (in ppm): Silurian alum and siliceous shale, Thuringia-Vogtland, Ti $860, \mathrm{~V} 900$, $\mathrm{Cr} 50$, Mo 150, Mn 70, Ni 60; Lower Carboniferous alum and siliceous shale, Westfallen, Ti 1,300, V 60, Cr 50, Mo 40, Mn 400, Ni 220; Permian Kupfer marl in lower Zechstein, Ti 1,100, V 110, Cr 80, Mo 110, Mn 850, Ni 70; asphalt shale in Triassic Haupt Dolomite, Ti 3,900, V 180, Cr 30, Mo 110, Mn 5,000, Ni 50; alum shale, lower Keuper (Late Triassic), Ti 1,300, V 20, Cr 40, Mo 20, Mn 800, $\mathrm{Ni} 100$; Liassic oil shale and bituminous rock, ranges, $\mathrm{Ti}--$ to $900, \mathrm{~V} 40$ to 270 , $\mathrm{Cr}--$ to $30, \mathrm{Mo} 10$ to $130, \mathrm{Mn}$-- to $900, \mathrm{Ni} 25$ to 160 ; Lower Cretaceous bituminous rock, Ti $3,400, \mathrm{~V} 40, \mathrm{Cr} 10, \mathrm{Mo} 20, \mathrm{Mn} 450, \mathrm{Ni} 50$; north alpine flysch shale, Ti $1,500, \mathrm{~V} 30, \mathrm{Cr} 75, \mathrm{Mo} 20, \mathrm{Mn} 500, \mathrm{Ni} 40$; Eocene north alpine bituminous marl, Ti 400, V 20, Cr--, Mo--, Mn 200, Ni 10.-EBT

Schopf, J. M. See Breger, I. A. 00037

Schopf, J. W. See Barghoorn, E. S. 00010

00236 Schröder, A. Die Metallgehalte des Posidonienschiefers [The metal contents of the Posidonian shales (in German)], in Brockamp, Bernhard, Zür Paläogeographic und Bitumenführung des Posidonienschiefers im deutschen Lias: Archiv Lagerstättenf., no. 77, 59 p., 1944.

Spectral analysis and chemical study of the bituminous rocks of the Posidonienschiefer of Lias and near Schneflingen [northern Germany] showed that they are enriched in $\mathrm{Cu}, \mathrm{V}, \mathrm{Cr}, \mathrm{Mo}, \mathrm{Ni}$, and $\mathrm{Co}$. Other metals such as $\mathrm{Pb}$ and $\mathrm{Sn}$ are in amounts less than $10 \mathrm{ppm}$. The mean values were (in ppm): V 430, Cu 230, Cr 120, Mo 80, Ni 30, Co 10, and organic substance 13 percent. The range in mean values for the Posidonienschiefer calculated from the author's data and from the literature are (in ppm): V 50-500, Cr 20-100, Mo 10-70, Ni 2090 , and $\mathrm{Co} 10-30$. V, $\mathrm{Cu}, \mathrm{Mo}$, and $\mathrm{Ni}$ contents seen in the Posidonienschiefer are typical of sapropelite.-EBT

Schroll, E. See Brandenstein, M.00038

Schroll, E. See Janda, I. 00219

00237 Schüller, Arno. Die Metallisation im Kupferschiefer und Dolomit des Unteren Zechsteins in den Bohrungen Spremberg 13E/57 and 3/54 [The metallization in the Kupferschiefer and dolomite of the lower Zechstein in the bore holes Spremberg $13 \mathrm{E} / 57$ and 3/54 (in German)]: Geologie, v. 7, p. 651-675, 1958.

Ore minerals, genesis, and chemistry of newly discovered mineralized Kupferschiefer and dolomite in the lower Zechstein on the east edge of the Lusatian Massif are described. The mineralization of the Kuperfschiefer is syngenetic; the mineralization of the dolomite is the result of migration of the ore and impregnations. The ore is found in the Mansfeld facies of the Kupferschiefer. Analyses showed the range of contents to be (in percent) in the dolomitic marlstone from bore hole 13E/57: $\mathrm{Cu} 0.02-0.03, \mathrm{~Pb} 1.16-3.78, \mathrm{Zn} 0.06-1.01$; in dolomitic marly shale, $\mathrm{Cu} 0.03-1.09$, $\mathrm{Pb} 0.14-4.22, \mathrm{Zn} 0.10-3.99$; in marly shale from bore hole $3 / 54$ : Cu $0.02-0.21, \mathrm{~Pb}$ $0.11-0.75, \mathrm{Zn} 0.15-4.25$.-EBT

00311 Schüller, Arno. Metallisation und genese des Kupferschiefers von Mansfeld [Metallization and genesis of the Kupferschiefer of Mansfeld (in German)]: Deutsche Akad. Wiss. Berlin Abh., math.-phys. KI., v. 1958, no. 6, 9 p., 1959. 
The bitumen in the Kupferschiefer is about 1 percent easily soluble and as much as 14 percent soluble with difficulty. All of the $V$ is fixed on the bitumen, but none of the Mo and $U$ is. Fine calcite grains are intimately mixed with the bitumen, suggesting that the calcite was precipitated by bacteria; it is well known that sulfur bacteria precipitate $\mathrm{CaCO}_{3}$ from sea water in this form. Chalcopyrite, sphalerite, and galena also seem to be precipitated from microorganisms. A four-step mineralization of the Kupferschiefer is theorized.--EBT

Schultz, L. G. See Tourtelot, H. A. 00279

Searight, W. V. See Moxon, A. L. 00154

Searight, W. V. See Moxon, A. L. 00238

Searight, W. V. See Moxon, A. L. 00239

00304 Seibold, Eugen; Müller, German; Fesser, Hermann. Chemische Untersuchungen eines Sapropels aus der mittleren Adria [Chemical investigation of some sapropels from the Adriatic (in German)]: Erdöl u. Kohle, v. 11, no. 5, p. 296-300, 1958.

A sapropelite sediment from middle of the Adriatic Sea shows characteristic fine layering (annual layers) and a high content of organic matter. Ratios of V:Mo and organic $\mathrm{C}: \mathrm{N}$ cited in the literature agree with those found in this sediment, so that these sediments are a Recent model for true black shales. Quantitative spectrochemical analyses showed the following average values (in ppm): light layers: Co 4.5, Cr 40, Mo 22, Ni 32, V 149; dark layers: Co 6, Cr 54, Mo 25, Ni 60, V 155; fine laminated parts: Co $5, \operatorname{Cr} 50, \mathrm{Mo} 23, \mathrm{Ni} 46, \mathrm{~V} 152$; and in homogeneous parts: Co 7.5, Cr 85, Mo 5.5, Ni 52, V 225.--EBT

00305 Seidov, A. G.; Zul'fugarly, D. I. Petrografo-mineralogicheskaya kharacteristika $i$ soderzhaniye mikroelementov $v$ glinakh maykopskoy svity Azerbaydzhana [Petrographic and mineralogical characteristics and content of trace elements in clays of the Maikop Formation of Azerbaidzhan (in Russian)]: Azerbaidshan. Gos. Univ., Uchenye Zapishi, Ser. Geol.-Geograf. Nauk, no. 5, p. 67-72, 1959.

Chemical and mineralogical analyses indicate that the [Tertiary] Maikop Formation was deposited in a marine basin where favorable alkaline and chemical reducing conditions existed for bitumen and oil formation. Mn content $(8,100$ and $558 \mathrm{ppm})$ in clays of the Upper Maikop in the Kobystan and Kirovabad regions is significantly higher than that of Lower Maikop clays $(4,300$ and $320 \mathrm{ppm})$. $V$ content $(220$ $\mathrm{ppm}$ ) in clays of the Upper Maikop of Kobystan is high in comparison with clay of the Lower Maikop $(160 \mathrm{ppm})$. In the Kirovabad region $\mathrm{V}$ content was higher in the Lower Maikop (210 ppm). Comparison of concentrations of $\mathrm{Mn}$ and $\mathrm{V}$ in deposits of the Maikop Formation with the productive strata of Apsheron shows that accumulation of these elements occurred under different conditions, resulting in different concentrations.-Referativnyy Zhur., 1961, 7v39, modified.

00306 Serikov, YU. I. K voprosu o proyiskhozhdenii urana $\vee$ khadumskikh glinakh [The question of the origin of uranium in Khadum shales (in Russian; English abs.)]: Geokhimiya, no. 3, p. 253-257, 1964; English translation: Geochemistry Internat., no. 2, p. 229-232, 1964.

Anomalous radioactivity of cores from a drill hole in eastern Fore-Caucasus was investigated by geophysical, radiometric, chemical, and granulometric analyses. The radioactivity occurred in the Khadum shales, of Tertiary age, which are dark-colored marine shales underlying the Maikop clays. The $U$ in the Khadum shales is syngenetic and is genetically related to the organic matter; a direct relationship exists between $U$ and urganic $C$ contents. The organic matter probably derived from phytoplakton; U may have been absorbed from the water by these plants. Possibly, slow sedimentation accounts for the enrichment of organic matter in these shales.EBT

Shabalin, V. V. See Adyshev, M. M.00002 
00307 Shaw, D. M. The geochemistry of thallium: Geochim. et Cosmochim. Acta, v. 2 , p. 118-154, 1952a.

A double-arc spectrographic method, precision \pm 20 percent, was used to determine $\mathrm{Tl}$ in silicates. Sensitivity limit is close to $0.05 \mathrm{ppm} \mathrm{TI}$. Tl closely resembles Rb in its geochemical behavior and occurs in igneous minerals and rocks by substitution for $\mathrm{K}$. During erosion $\mathrm{Tl}$ goes into true solution as the univalent cation but is removed from solution by adsorption in clays. Under strong oxidizing conditions it accumulates in manganiferous deposits; in a strong reducing environment $\mathrm{Tl}$ slightly concentrates in carbonaceous shales. The geochemical balance is discussed and the crustal abundance is calculated to be $1.3 \mathrm{ppm}$. Some aspects of $\mathrm{Tl}$ geochemistry are relevant to fundamental questions of petrogenesis. Carbonaceous shales (6 samples) average $1.23 \mathrm{ppm} \mathrm{Tl}$ compared to $0.69 \mathrm{ppm}$ in 18 samples of clays and shales.-EBT

00308 Shaw, D. M. The geochemistry of indium: Geochim. et Cosmochim. Acta, v. 2 , p. $185-206,1952$ b.

A double-arc spectrographic procedure was used to analyze numerous minerals and rocks for In. The method had sensitivity of the order of $0.02 \mathrm{ppm}$ In with precision of \pm 20 percent. Argillaceous sediments contain a little In, deposited by oxidation and hydrolysis of eroded material. Strong reducing environments cause the slight In-enrichment in carbonaceous rocks. The crustal abundance of In is $0.11 \mathrm{ppm}$. The probable distribution of In throughout the earth is briefly discussed from thermochemical data. The average content of In in argillaceous sediments (including present-day marine samples) is $0.054 \mathrm{ppm}$.-Author's abs. condensed.

00309 Shaw, D. M. Variation during metamorphism, pt. 1 of Trace elements in pelitic rocks: Geol. Soc. America Bull., v. 65, no. 12, pt. 1, p. 1151-1166, 1954a.

Trace elements were determined spectrographically in 63 rock samples representing all grades of metamorphism of the pelitic Devonian Littleton Formation in New Hampshire. Mean contents are, in ppm (standard deviations in parentheses): Ga 19 (6.3), Cr 110 (33), V 120 (39), Li 110 (104), Ni 64 (26), Co 18 (6.6), Cu 18 (18), Sc 14 (7.4), Zr 200 (73), Y 45 (20), S 710 (310), Pb 24 (12); in low-grade pelites: Ga 20.8 (7.5), Cr $116(38.7)$, V 109 (44), Li 54.7 (22), Ni 80.5 (33.4), Co $16.8(4), \mathrm{Cu} 23.1$ (15.5), Sc 11.3 (4.3), Zr 191 (68), Y 38.8 (11.5), Sr 524 (416), $\mathrm{Pb} 16.1$ (9.3); $\mathrm{Be}, \mathrm{Mo}, \mathrm{Sn}, \mathrm{La}$, and $\mathrm{Ag}$ were usually less than $30,10,20,100$, and $1 \mathrm{ppm}$, respectively; Ba almost always exceeds $1,000 \mathrm{ppm}$. Statistical tests show rather a wide range in original composition. The concentration of most elements remained constant during regional metamorphism; $\mathrm{Ni}$ and $\mathrm{Cu}$ decrease slightly, and $\mathrm{Li}$ and $\mathrm{Pb}$ increase 100 percent due to metasomatism at the trace-element level.Author's abs., modified.

00310 Shaw, D. M. Geochemical relations, pt. 2 of Trace elements in pelitic rocks: Geol. Soc. America Bull., v. 65, no. 12, pt. 1, p. 1167-1182, 1954b.

The range in trace-element composition of pelitic shales, schists, and gneisses was investigated and compared with previous work on similar materials. It appears that the range in composition for almost every element extends from 0 to about 2 times the mean value. Fairly good positive correlation was found between $\mathrm{Cr}$, $\mathrm{V}$, and $\mathrm{Ni}$ and to some extent $\mathrm{Co}$; the most regular correlation is between $\mathrm{Ni}$ and $\mathrm{Cr}$. In general, content of the trace elements studied is what would be expected from erosion and transfer from the average igneous rock. $\mathrm{Cu}$ is an exception with a clear loss; $\mathrm{Li}$ and $\mathrm{Sr}$ show an increase. Comparison with suites of silicic and basic igneous rocks emphasizes some differences between these and pelitic rocks, but in many cases the composition fields overlap extensively. Certain revisions in crustal abundance (average igneous rock) figures are suggested.-Author's abs., condensed.

00312 Shcherbakov, YU. G.; Perezhogin, G. A. K geokhimii zolota [Gold geochemistry]: Geokhimiya, no. 6, p. 518-528, 1964; English translation: Geochemistry Internat., no. 3, p. 489-496, 1964 [1965]. 


\section{BIBLIOGRAPHY OF MINOR ELEMENTS IN BLACK SHALES}

Data from 300 analyses by the Hamaguchi radioactivation method on the Au content of meteorites, igneous and sedimentary rocks, and some rock-forming minerals are presented. Analyses of 39 samples of shales and sandstone collected from carbonate and flysch formation of Paleozoic age showed an average Au content of 0.0036 ppm.-EBT

00301 Sheldon, R. P. Geochemistry of uranium in phosphorites and black shales of the Phosphoria Formation: U.S. Geol. Survey Bull. 1084-D, p. 84-112, 1959.

$\mathrm{U}$ in the Phosphoria Formation of Permian age in the western phosphate field occurs mostly in the phosphorite and partly in black shale. However, some of the phosphorites and most of the black shales of the formation are practically nonuraniferous. Few data are available on the mode of occurrence of $U$ in black shale, but, from chemical and stratigraphic considerations, it seems possible that the $\mathrm{U}$ is deposited as disseminated $\mathrm{UO}_{2}$ in a reducing acid depositional environment. Two zones of black shale a few feet thick in the Meade Peak Phosphatic Shale Member contain as much as 0.012 percent U.-Author's abs., modified.

Shimkus, K. M. See Kochenov, A. V. 00405

Shimp, N. E. See Potter, P. E. 00261

Silina, O. M. See Ostroyumov, E. A. 00245

00302 Sindeeva, N. D.; Kurbanova, N. Z. O klarke selena v nekotorykh gornykh porodakh SSSR [The clarke of selenium in some rocks of the USSR]: Akad. Nauk SSSR Doklady, v. 120, p. 353-355, 1958; English translation: Acad. Sci. USSR Doklady, Geochemistry Sec., New York, Consultants Bur., Inc., p. 61-63 [1959].

Previous analyses for Se are discussed and new analyses of rocks in the USSR presented. From the regions near the Baltic Sea 3 samples of Dictyonema slates of Silurian age contained $0.9,0.7$, and $0.3 \mathrm{ppm}$ Se.--EBT

Sisson, L. L. See Moxon, A. L. 00239

00303 Skjeseth, Steinar. Uran i kambrisk alunskifer i Oslofeltet og tilgrensende områder [Uranium in Cambrian alum shales of the Oslo region and adjacent districts (in Norwegian; English summ.)]: Norges Geol. Undersökelse, no. 203, Årb. 1957, p. $100-111,1958$.

The black alum shales in the Oslo region, Norway, were investigated for their $U$ content. These shales comprise a black shale formation in the Cambrian System in southern Norway. The uppermost Cambrian zones contain the highest radioactivity in the region; $U$ content is from 50 to $100 \mathrm{ppm}$ with a maximum of $170 \mathrm{ppm}$ in thin layers.-EBT

Slack, H. A. See Krumbein, W. C. 00208

Smith, J. F., Jr. See Ketner, K. B. 00196

00299 Spears, D. A. The radioactivity of the Mansfield Marine Band, Yorkshire: Geochim. et Cosmochim. Acta, v. 28, p. 673-681, 1964.

The distribution of radioactivity in the Mansfield Marine Band, a dark-gray shale that is darkest where typically marine fauna occur, was studied by chemical and radiometric techniques. Organic content ranges from 1.33 to 12.24 percent and Th content from 3.7 to $13.5 \mathrm{ppm}$. Th is probably associated with clay minerals and possibly was fixed during weathering of the source rocks. U content ranges from 1 to $21 \mathrm{ppm}$. Some $U$ is concentrated in phosphatic material but most is associated with clay minerals, and there is an absence of uranium-rich minerals. The presence of reducing conditions, a slow rate of deposition, and salinity were factors controlling the sorption of $\mathrm{U}$. $\mathrm{K}_{2} \mathrm{O}$ content ranges from 2.96 to 4.47 percent; $\mathrm{P}_{2} \mathrm{O}_{5}$ content from 0.06 to 1.18 percent, and $\mathrm{S}$ content from 0.03 to 7.62 percent.EBT 
00300 Spears, D. A. Boron in some British Carboniferous sedimentary rocks: Geochim. et Cosmochim. Acta, v. 29, p. 315-328, 1965.

B contents in sedimentary rocks from the British Carboniferous are reviewed and additional data presented for the Mansfield Marine Band in the Westphalian Coal Measures in Yorkshire and its equivalent horizon in Durham, the Ryhope Marine band. Most of the $B$ is contained in illite and was fixed during weathering of source rocks. Although the use of $B$ as a paleosalinity indicator is therefore precluded, it may reflect conditions of the source area. B contents of Yoredale and Coal Measure sediments differ; this possibly reflects a different degree of chemical weathering in the source areas. The variation of $\mathrm{K}, \mathrm{B}, \mathrm{B}: \mathrm{K}$ ratio, the paleosalinity, and $\mathrm{eU}_{3} \mathrm{O}_{8}$ through the $\mathrm{Ryhope}$ and Mansfield Marine Bands from 3 different drill holes and a plot of $K$ against $B$ for the Coal Measure and Yoredale sediments are presented.-Author's abs., modified.

00275 Stadler, Gerhard. Uran-Anreicherungen im marine Oberoligozän der Niederrheinischen Bucht [Uranium enrichment in marine Upper Oligocene of the Lower Rhine Embayment (in German)], in Ahrens, Wilheim, ed., Die Niedrrheinische Braunkohlenformation: Fortschr. Geologie Rheinland u. Westfalen, v. 1, p. 91-92, 1958.

In the marine rocks of late Oligocene age of the Lower Rhine Embayment, fossil bone and driftwood contain from 100 to $200 \mathrm{ppm}$ eU. The $U$ is absorbed by coaly matter, and even more strongly by phosphatic substances, from sea water.-Author's abs., modified

Stanfield, K. E. See Thorne, H. M. 00287

00295 Stanton, R. L. Constitutional features of the Mount Isa sulphide ores and their interpretation: Australasian Inst. Mining and Metallurgy Proc. 205, p. 131-153, 1963.

Analyses of ores from Mount Isa and the Northern Leases showed that $\mathrm{Pb}-\mathrm{Zn}$ and $\mathrm{Cu}$ ores have the same simple trends confirming that the two ore types and their host rocks are genetically closely related. A volcanic-sedimentary origin for the sulfides appears compatible with the present findings. Vague association of sulfide type with carbonate abundance and contrasting close association between ore type and carbonate form and origin indicate important biological influence on sulfide deposition, probably in a reducing environment. $\mathrm{Cu}$ sulfides were probably deposited with reef detritus and the $\mathrm{Pb}$ and $\mathrm{Zn}$ sulfides with off-reef shales. $\mathrm{Cu}$ ores contain the following ranges of constituents (in percent): $\mathrm{Cu} 2.5-3.3, \mathrm{Fe} \mathrm{10.1-}$ 10.8, $\mathrm{S} \mathrm{6.1-7.7,} \mathrm{CaO} 13.1-15.6, \mathrm{CO}_{2}$ 19.8-24.8; $\mathrm{Pb}-\mathrm{Zn}$ ores from Mount Isa and the Northern Leases contain: $\mathrm{Cu} 0.04-0.18, \mathrm{Zn} \mathrm{5-7.8,} \mathrm{Pb} \mathrm{3.5-10.1,} \mathrm{Ag} \mathrm{0.00017.}$ $0.00074, \mathrm{Fe} 11-16.3, \mathrm{~S} 10.6-17.7, \mathrm{CaO} 5-8.6, \mathrm{Co}_{2} 8.8-14.3$.-EBT

00296 Stanton, R. L.; Baas Becking, L. G. M. The formation and accumulation of sedimentary sulphides in seaboard volcanic environments (in English): Koninkl. Nederlandse Akad. Wetensch. Proc., ser. B., v. 65, no. 3, p. 236-243, 1962.

Present-day shoreline geothermal activity in New Britain and the Solomon Islands was investigated as a possible guide to ore-forming processes in the past. Acid volcanic waters were found to carry heavy-metal ions such as $\mathrm{Fe}, \mathrm{Cu}$, and $\mathrm{Zn}$ in solution. When these solutions enter sea water the pH rises and the Eh falls, causing the precipitation of the metals as oxides, hydroxides, carbonates, and basic carbonates. If the precipitates sink into muds rich in organic material, sulfatereducing bacteria may reduce these compounds to sulfides. Such deposits of sedimentary sulfides may be expected only near the shores of volcanic islands where Eh-pH conditions are right. The ranges of $\mathbf{E h}-\mathrm{pH}$ conditions in natural waters and the stability fields are presented.-.JDV

Starke, Rainer. See Leutwein, Friedrich. 00170

Steckel, F. See Gil-av, E. 00120 


\section{BIBLIOGRAPHY OF MINOR ELEMENTS IN BLACK SHALES}

00297 Steinbrecher, Bodo. Die petro- und erzfazielle Differenzierung der Kupferschieferzone in der Edderitzer Mulde [Petrographic- and ore facies differentiation of the Kupferschiefer zone in the Edderitz Basin (in German)]: Zeitschr. angew. Geologie, v. 5, no. 5, p. 201-204, 1959.

The ore facies and the petrographic facies of the Kupferschiefer and the Kupferschiefer zone in the Edderitz Basin change from southeast to northwest: (1) zone with $\mathrm{Zn}$ content $>0.7$ percent, (2) zone with $\mathrm{Pb}$ content $>1$ percent, (3) zone with $\mathrm{Cu}$ content $>0.3$ percent, and (4) zone with $\mathrm{Zn}$ content $>0.7$ percent. These zones overlap; correspondingly there is a $\mathrm{Pb}-\mathrm{Zn}$ enriched zone southeastward and a $\mathrm{Pb}-\mathrm{Cu}$ enriched zone toward the middle of the basin. There is a corresponding change from limy to dolomitic from southeast to northwest. Possibly conditions for precipitation of $\mathrm{Zn}$ were more favorable in the region near the shore.--Author's summ., modified.

Stevens, R. E. See Wells, R. C. 00323

00298 Stock, Alfred; Cucuel, Friedrich. Die Verbreitung des Quecksilbers [The distribution of quicksilver (in German)]: Naturwissenschaftern, v. 22, no. 22/24, p. $390-393,1934$.

$\mathrm{Hg}$ content in the composite sample of 36 European Paleozoic shales was found to be $0.48-0.53 \mathrm{ppm}$; in a composite sample of Dictyonema shale from southern Sweden, $0.25 \mathrm{ppm}$; in 3 samples of Mansfeld Kupferschiefer, 0.15, 0.12, $0.12 \mathrm{ppm}$; in marine shale of Carboniferous age (with Anthracoceras), $1.43 \mathrm{ppm}$. Hg contents in waters and other materials and rocks are discussed.-EBT

Strahl, E. O. See Bates, T. F. 00012

Strahl, E. O. See Bates, T. F. 00027

00290 Strahl, E. O. An investigation of the relationships between selected minerals, trace elements, and organic constituents of several black shales: University Park, Pa., Pennsylvania State Univ. Dept. Mineralogy and Petrology, 155 p. (Tech. Rept. NYO-7908, prepared for U.S. Atomic Energy Comm.), 1958; abs., Geol. Soc. America Bull. 70, no. 12, p. 1682, 1959.

Analyses for total $\mathrm{C}$, organic $\mathrm{C}$, alaphatic and aromatic hydrocarbons, carbonate, total $\mathrm{Fe}$, iron oxide, pyrite, total silicate, quartz, kaolinite, illite, amorphous silicate $\mathrm{U}, \mathrm{Mo}, \mathrm{Mn}$, and quartz grain size were made on 280 samples of Chattanooga and Ohio Shales from the United States, the St. Hippolyte Shale of France, and the alum shale of Sweden. Pyrite, organic $C$, and $U$ vary together. Mo and $M n$ coprecipitate in the presence of carbonate minerals. Mean trace-element content is, in ppm (standard deviation in parentheses): Chattanooga Shale, Mo 240 (250), Mn 360 (260), U 53 (20); Ohio Shale, Mo 250 (70), Mn 360 (200), U 8 (6); St. Hippolyte Shale, Mo 750 (580), Mn 970 (900), U 1,259 (3,170); and alum shale, Mo $180(80), \mathrm{Mn} 280(160)$, U $188(93)$. Whether the organic material is bituminous or carbonaceous appears related to type of material available and degree of oxidation.-Author's abs., condensed.

00291 Strakhov, H. M.; Rodionova, K. F.; Zalmanzon, E. S. K geokhimii neftenosnykh otlozhenii (nizhnefranskiye porody Vtorogo Baky): Akad. Nauk SSSR, Inst. Geol. Nauk, Trudy, Geol. Ser., v. 155, no. 66, p. 3-115, 1955; English translation: Burgunker, Mark, A contribution to the geochemistry of reservoir formations (the Lower Frasnian of the Volga-Urals): Internat. Geology Rev., v. 1, nos. 5-7, p. $1-23,11-47,41-61,1959$.

Maximum concentrations of hydrocarbons and the largest accumulations of ancient organic matter on the Russian platform occur in the Domanik Formation of early Frasnian age (Late Devonian) in the Volga-Ural region, USSR. $\mathrm{Cu}, \mathrm{Cr}, \mathrm{Ni}, \mathrm{Co}$, and $\mathrm{V}$ contents consistently increase through the sequence sandstone, siltstone, clay, but diverge widely in the sequence clay, marl, limestone. $\mathrm{Fe}, \mathrm{Mn}, \mathrm{P}, \mathrm{Cu}$, and $\mathrm{Sr}$ contents calculated to percentage of carbonate-free material, increase in the sequence clay, marl, limestone, whereas $\mathrm{Cr}, \mathrm{Ni}$, and Co contents calculated to the same basis, decrease. Mean concentrations in Domanik rocks are (in ppm): in marl; $\mathrm{Cu} 73$, 
$\mathrm{Cr}$ 17, $\mathrm{Ni} 71, \mathrm{Co}$ none, $\mathrm{V}$ 144; in argillaceous limestone: $\mathrm{Cu} 24, \mathrm{Cr}$ none(?), $\mathrm{Ni}$ 32, Co none, V 79. In Pashysky and sub-Domanik rocks of early Frasnian age

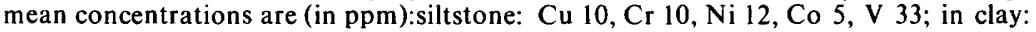
$\mathrm{Cu} 44, \mathrm{Cr} 34, \mathrm{Ni} 42$, Co 8, V 104; in marl: $\mathrm{Cu} 32, \mathrm{Cr} 17, \mathrm{Ni} \mathrm{36}, \mathrm{Co} 4, \mathrm{~V} 72$; in argillaceous limestone: $\mathrm{Cu} 23, \mathrm{Cr} 12, \mathrm{Ni} 14$, Co none, $\mathrm{V}$ 23.-EBT

Strobell, J. D., Jr. See McKelvey, V. E. 00158

Strock, L. W. See Goldschmidt, V. M. 00110

00292 Strock, L. W. Zur Geochemie des Lithiums [On the geochemistry of lithium (in German)]: Gesell. Wiss. Göttingen Nachr., math.-phys. Kl., v. 1, no. 15, p. $171-204,1936$.

A spectrographic method for analyzing rocks and minerals for $\mathrm{Li}$ is described. The composite sample of 36 European Paleozoic shales showed $135 \mathrm{ppm} \mathrm{Li}_{2} \mathrm{O} ; 14$ Japanese Paleozoic shales, $92 \mathrm{ppm} \mathrm{Li}_{2} \mathrm{O} ; 10$ Japanese Mesozoic shales, $71 \mathrm{ppm}$; a sample of Kulmschiefer from Lehesten, Thuringen, $300 \mathrm{ppm}$; and a sample of the Mansfeld Kupferschiefer, $660 \mathrm{ppm}$. The average for all clays, including deepsea clays, is $120 \mathrm{ppm} \mathrm{Li}{ }_{2} \mathrm{O}$.- EBT

00293 Strøm, K. M. A concentration of uranium in black muds: Nature, v. 162, p. $922,1948$.

In the Cambrian black shales of the Oslo, Norway, area, there is a considerable concentration of $U$ ranging from 28 to $180 \mathrm{ppm}$. A modern concentration of $U$ was studied in black muds forming under anaerobic conditions in Norwegian fjords. All analyses were made by the ether-extraction method. U contents ranged from 13 to $60 \mathrm{ppm}$. A definite connection between drainage from areas underlain by granite and $U$ content in the black muds exists. Two of the three fjords which are marked by their low values are, as a rule, very well ventilated, and in the Drammensfjord the muds are not very black. Precipitation of $U$ probably starts by the formation of sulfide on the interface between the upper ventilated brackish waters and the salt waters of the deep, which contain hydrogen sulfide.--EBT

00294 Strutt, R. J. On the radioactive minerals: Royal Soc. London Proc., v. 76A, p. 88-101, 312, 1905.

Included in the analyses of minerals for radioactive materials is an analysis of kolm from the alum shale in Sweden. The kolm showed $0.01 \mathrm{ppm} \mathrm{RaBr}_{2}$ and $3,770 \mathrm{ppm}$ $\mathrm{U}_{3} \mathrm{O}_{8}$. $\mathrm{Ra}$ and $\mathrm{U}$ were determined in ash and afterward referred back to the weight of the unburnt material.-EBT

00276 Sugawara, Ken; Morita, Yoshimi. On the revision of the Clarke numbers of copper and zinc (in English): Mikrochemie, v. 36-37, p. 1093-1099, 1951.

Analyses of various kinds of rocks, especially of Japanese but also of other Asiatic, European, and American origins, lead to a revision of the "Clarke number" for $\mathrm{Cu}$ and $\mathrm{Zn}$ (this number represents the percent by weight for an element in the outer 16-km layer of the earth's surface). The number for $\mathrm{Cu}$ is lowered and that for $\mathrm{Zn}$ raised. The composite sample of 10 Japanese Mesozoic shales contains 55 ppm $\mathrm{Cu}$ and $100 \mathrm{ppm} \mathrm{Zn}$; the composite of 14 Japanese Paleozoic shales, $40 \mathrm{ppm}$ $\mathrm{Cu}$ and $100 \mathrm{ppm} \mathrm{Zn;} \mathrm{and} \mathrm{the} \mathrm{composite} \mathrm{of} 36$ European Paleozoic shales, $65 \mathrm{ppm}$ $\mathrm{Cu}$ and $130 \mathrm{ppm} \mathrm{Zn}$.- Authors' abs., modified.

Swanson, V. E. See Conant, L. C. 00055

00277 Swanson, V. E.; Landis, E. R. Geology of a uranium-bearing black shale of Late Devonian age in north-central Arkansas: Arkansas Geol. Conserv. Comm. Inf. Circ. 22, 16 p., 1962.

Selected samples of black, semilustrous organic material collected from a small lens of marine black shale in the basal sandstone of the Boone Formation in northcentral Marion County, Ark., contain as much as 0.71 percent $U$. This and several other lenses of black shale are in a probable northward extension of the Sylamore 


\section{BIBLIOGRAPHY OF MINOR ELEMENTS IN BLACK SHALES}

Sandstone Member of the Chattanooga Shale, of either Late Devonian or Early Mississippian age, or both. Relatively pure samples of colloidal humic material contain the most $\mathrm{U}$ and are comparable in general appearance, physical characteristics, and range in $U$ content to kolm in shales of Cambrian age of Sweden. Semiquantitative spectrographic analyses for 11 other metals show that none are abnormally concentrated in samples of organic materials, as compared to bulk samples. The other metals have no direct relation to U. Contents in 5 shale samples showed the following ranges (in percent): $\mathrm{Ti} 0 . \mathrm{X}$ to $0 . \mathrm{X}-$, Mn $0.00 \mathrm{X}-$ to $0.0 \mathrm{X}-$, $\mathrm{Co} 0.00 \mathrm{X}+$ to $0.0 \mathrm{X}-, \mathrm{Cr} 0.00 \mathrm{X}+$ to $0.0 \mathrm{X}_{-}, \mathrm{Cu} 0.00 \mathrm{X}+$ to $0.0 \mathrm{X}-, \mathrm{Mo} 0.00 \mathrm{X}+$ to $0.0 \mathrm{X}-$, $\mathrm{Ni} 0.0 \mathrm{X}$ - to $0.0 \mathrm{X}+, \mathrm{Pb} 0.00 \mathrm{X}+$ to $0.0 \mathrm{X}-, \mathrm{V} 0.0 \mathrm{X}$ - to $0.0 \mathrm{X}, \mathrm{Zn} 0.0 \mathrm{X}$ to $0.0 \mathrm{X}+, \mathrm{U}$ (chemical) $0.00 \mathrm{X}$ to $0.0 \mathrm{X}-$; in the humic matter, $\mathrm{Ti} .0 \mathrm{X}$ to $0 . \mathrm{X}+$, $\mathrm{Mn} 0.00 \mathrm{X}$ - to $0.00 \mathrm{X}+, \mathrm{Co} 0.00 \mathrm{X}$ to $0.0 \mathrm{X}, \mathrm{Cr} 0.000 \mathrm{X}$ to $0.00 \mathrm{X}+, \mathrm{Cu} 0.00 \mathrm{X}$ to $0.0 \mathrm{X}$, Mo $0.00 \mathrm{X}+$ to $0.0 \mathrm{X}-$, Ni $0.00 \mathrm{X}$ to $0.0 \mathrm{X}, \mathrm{Pb} 0.00 \mathrm{X}$ + to $0.0 \mathrm{X}-, \mathrm{V} 0.000 \mathrm{X}$ to $0.0 \mathrm{X}-, \mathrm{Zn} 0.0 \mathrm{X}$ to $0 . \mathrm{X}_{-}, \mathrm{U}$ (chemical) $0.0 \mathrm{X}$ to $0 . \mathrm{X}+$; modal mean of 11 samples of Chattanooga and 18 of Woodford Shales, Ti $0 . X$, Mn 0.00X-, Co $0.00 X_{-}, \mathrm{Cr}$ $0.00 \mathrm{X}_{+}, \mathrm{Cu} 0.0 \mathrm{X}_{-}, \mathrm{Mo} 0.0 \mathrm{X}-$, Ni $0.0 \mathrm{X}-, \mathrm{Pb} 0.00 \mathrm{X}-, \mathrm{V} 0.0 \mathrm{X}, \mathrm{Zn} 0.0 \mathrm{X}-?, \mathrm{U}$ (chemical) $0.00 \mathrm{X}_{-}$.- Authors' abs., modified.

00289 Swanson, V. E. Geology and geochemistry of uranium in marine black shales, a review: U.S. Geol. Survey Prof. Paper 356-C, p. 67-112, 1961.

Based on known and theoretical relations of $U$ with other constituents, 9 mechanisms of $U$ emplacement and the amounts by each are given for a unit of the Chattanooga Shale ( $79 \mathrm{ppm} \mathrm{U})$, black mud of a Norwegian fjord (60), organic-rich mud from the Gotland deep of the Baltic Sea (10), and phosphatic black shale of Pennsylvanian age (50). Most of the $U$ in the first two sediments probably was directly precipitated in the presence of $\mathrm{H}_{2} \mathrm{~S}$ or sorbed onto solid and soluble humic-type organic matter. In Baltic Sea mud, about one-half of the $U$ is sorbed by soluble organic matter derived from land and by partly decomposed plankton; the other half is distributed among clastic and phosphate minerals; only very minor amounts result from $\mathrm{H}_{2} \mathrm{~S}$ precipitation. Most of the $U$ in Pennsylvanian phosphatic black shales is in the phosphate; solid and soluble humic-type organic matter contain much of the rest.Author's abs., condensed.

Tausch, E. H. See Turekian, K. K.00352

Tedrow, J. C. F. See Ugolini, F. C. 00346

00286 Temple, K. L. Syngenesis of sulfide ores-an evaluation of biochemical aspects: Econ. Geology, v. 59, no. 8, p. 1473-1491, 1964.

Conditions required for large-scale reduction of sulfate, quantitative aspects, the potential and the limitations of microbial sulfate-reduction, and specifically, the biochemical factors involved for syngenetic sulfide ore formation are discussed. Quantitatively and qualitatively biologic sulfate reduction is a satisfactory element in the syngenetic theory of ore formation. Sulfate reduction is not limited to any physical type of basin but is determined by a combination of factors that can be summed up in terms of $O$ supply and $O$ consumption. Rate of sulfate-reduction is sufficient to explain most massive ore deposits. A water volume of $242 \mathrm{cu} \mathrm{ft}$ would produce 1 ton of $\mathrm{CuS}$, if sufficient $\mathrm{Cu}$ were available and the $\mathrm{H}_{2} \mathrm{~S}$ could be converted to $\mathrm{CuS}$ quantitatively. Desulfovibrio or other sulfate reducers could have persisted since the earliest time of biologic evolution.-Author's abs. and conclusions, condensed.

Thoenen, J. R. See Pallister, H. D. 00263

00287 Thorne, H. M.; Murphy, W. I. R.; Stanfield, K. E.; Ball, J. S.; Horne, J. W. Green River oil shales and products: Inst. Petroleum, Oil Shale and Cannel Coal. v. 2, p. 301-344, 1951.

Analyses of oil shales in the Green River Formation of middle Eocene age in the Rocky Mountain area are presented to show the chemical and physica characteristics of the shales. The composition of shale oil produced by differen retorting processes is also discussed. $\mathbf{P}_{2} \mathrm{O}_{5}$ content of 6 samples from Coloradc 
ranged from 1,100 to $5,600 \mathrm{ppm} ; \mathrm{V}_{2} \mathrm{O}_{5}$, from 30 to $310 \mathrm{ppm}$, both as determined on raw samples.-EBT

00284 Tikhomirova, E. S. K geokhimii slantsenosnykh otlozheniy Pribaltiyskogo basseyna [The geochemistry of the shale-bearing deposits of the Baltic basin]: Akad. Nauk SSSR Doklady, v. 136, p. 1209-1212, 1961, English translation: New York, Consultants Bur., Inc., v. 136, p. 17-19 [1962].

The Kukersite Shales of the Baltic basin of Middle Ordovician age were deposited along the southern margin of the Baltic shield in a normal marine basin. They contain more carbonates and organic matter and less terrigenous material than the genetically similar shales in Lower Volgian rocks of Late Jurassic age in the Volga region. Contents of $\mathrm{P}, \mathrm{V}, \mathrm{Ni}$, and $\mathrm{Cu}$ are considerably less than in Volgian rocks. All investigated elements in Kukersite Shales show a direct relationship with amount of terrigenous material and an inverse relationship with organic $\mathrm{C}$; in Lower Volgian shales biogenic factors were important in concentrating $\mathrm{P}$ and $\mathrm{Cu}$. In Kukersite shales the following average ranges were found (in ppm): $\mathrm{Fe} 12,000-15,600, \mathrm{Mn}$ $140-150$, P $270-300$, V 19-21, Cr 21-27, Ni 8-24, Co 10-13, Cu 0-tr; in Lower Volgian, Fe 20,900-27,900, Mn 142-800, P 900-5,140, V 41-109, Cr 56-73, Ni 30114, Co 14-18, Cu 9-50. Graphs presented show considerable organic material in these rocks.-EBT

00285 Tikhomirova, E. S. K voprosy o geokhimicheskoy podvizhnosti elementov pri obrazovanii sulfidnykh konkretsii $\mathrm{v}$ slantsenosnykh otlozheniyakh Volzhskogo i Pribaltiyskogo basseynov [The problem of the geochemical mobility of elements during the formation of sulfide concretions in shale-bearing deposits of the Volga and Baltic basins]: Akad. Nauk SSSR Doklady, v. 135, no. 6, p. 1501-1504, 1960; English translation: New York, Consultants Bur., Inc., p. 1098-1100 [1961].

Pyrite concretions were investigated during study of the lithology and geochemistry of shales in the Volga and Baltic basins. Dictyonema shales in the Baltic basin, overlying Obolus sandstones of Late Cambrian age, are characterized by intense pyritization. Shale deposits in the Volga basin, included in the Dorsoplanites panderi zone (Upper Jurassic), consist of calcareous clays with sapropelic intercalations, which are gray or brownish gray, generally unstratified, containing tracks of mudeaters. The nonsapropelic clays are gray to dark gray. Lower Volgian shales showed the following minor element contents, in $\mathrm{ppm}$ (contents of concretions in parentheses): Mn 240 (27), Ni 101 (23), Cu 45 (18), Mo 50 (26), Ti 2,230 (150), $\mathrm{Pb}$ nd (nd), As nd (nd), Ag 0.7 (1); Dictyonema shales, Mn 160 (30), Ni 41 (134), Cu $26(61)$, Mo $20(80)$, Ti 4,000 (150), Pb $30(1,160)$, As nd $(1,920)$, Ag tr $(2.7)$.EBT

00288 Tikhomirova, E. S. K voprosii o raspedelenii rasseyannykh soderzhaniy elementov $v$ otlozheniyakh Tul'skogo gorizonta yugo-zapadnoy chasti Podmoskovnogo basseyna [Distribution of trace elements in sediments of the Tula horizon in the southwestern part of the Moscow Basin]: Akad. Nauk SSSR Doklady, v. 117, p. 661-664, 1957; English translation: New York, Consultants Bur., Inc., Acad. Sci. USSR Doklady, Geochemistry Sec., v. 115-117, p. 99-102 [1958].

The Tula horizon [of Carboniferous age] contains mostly shallow-water marine sandstones and siltstones and some lagoonal and continental deposits. Strong enrichment of all trace elements in the pelagic sediments was caused by intensive weathering of parent rocks in the source area in a hot, moist climate on a flat low-lying continent; decomposition of silicates and aluminosilicates released elements into solutions. Migration of the elements was aided by presence in the waters of humic compounds which served as protective colloids. Greater content of $\mathrm{Cr}, \mathrm{Ni}$, and $\mathrm{V}$ in Tula sediments than in lower Frasnian deposits [Late Devonian] is probably due to basic rocks in the source area of Tula sediments. Average contents in coarse silt, fine silt, silty clays, and pure clays show the following ranges (in ppm): $\mathrm{Cu} 19-25, \mathrm{Cr} 37-71, \mathrm{Ni} 14-45$, Co 7-14, V 50-138, Ti 4,400-10,300, $\mathrm{Mg} 3,900-16,000$, Be 3-9, Ga 20-110, and Ba 170-600.-EBT

00278 Tischendorf, Gerhard. Zur Genesis einiger Selenidvorkommen, insbesondere von Tilkerode im Harz [The genesis of some selenide occurrences, particularly of 


\section{BIBLIOGRAPHY OF MINOR ELEMENTS IN BLACK SHALES}

Tilkerode in Hartz (in German; English summ.)]: Freiberger Fortschungshefte, C 69, 128 p., 1959.

Mineralogy and paragenesis of Tilkerode-Hartz selenide occurrences was studied. Original hydrothermal solutions of the area did not contain most of the elements necessary for the formation of selenides but leached the elements from graptolite shale rich in trace elements. A zone of leaching $1 \mathrm{~m}$ thick exists on both sides of the vein. Therefore syngenetic concentration of Se in the clayslates is an important source for Se. Se content in the unaltered graptolite shale ranges from 2.0 to 3.63 $\mathrm{ppm}$, precious metals (in ppm): Au 0.3-1.3, Pd $<0.5$, Pt 0.01-0.05, $\mathrm{Rh}<0.01-$ 0.02 , and $R u$ 0.04-0.08, and maximum trace element content [estimated visually from a logarithmic graph] is (in ppm): $\mathrm{Cu} 120, \mathrm{Ag} 14, \mathrm{Zn} 210, \mathrm{Ni} 35, \mathrm{Sn} 17$, Cr 80 , Ba 7,000, Mn 550, V 190, Mo 12 , and Co 8 . Some previously unpublished Se analyses include Lower Devonian clayslate $0.32 \mathrm{ppm}$, Kolm shale east of Lerbach/Hartz 0.42, and Kolm shale near Lautental/Hartz 0.73.-EBT

Tomic, E. See Hecht, Friedrich. 00103

00415 Tourtelot, H. A. Minor-element composition and the organic carbon content of marine and nonmarine shales of Late Cretaceous age in the western interior of the United States: Geochim. et Cosmochim. Acta, v. 28, p. 1579-1604, 1964.

Differences in minor-element content of samples of shales of Late Cretaceous age show the effects of clay minerals and organic matter. Nearshore marine shales $(<1$ percent organic C) contain larger amounts of $\mathrm{As}, \mathrm{B}, \mathrm{Cr}, \mathrm{V}$, and $\mathrm{Zn}$ than do nonmarine carbonaceous shales (1-17 percent organic $\mathrm{C}$ ); the offshore shales (as much as 8 percent organic $\mathrm{C}$ ) contain even larger amounts. Co, Mo, $\mathrm{Pb}$, and $\mathrm{Zr}$ contents show no significant difference. Ga content is lower in marine samples. In general, $\mathrm{As}, \mathrm{Cr}, \mathrm{Cu}, \mathrm{Mo}, \mathrm{Se}, \mathrm{V}$, and $\mathrm{Zn}$ are concentrated in those offshore marine samples having the most organic $C$, but samples with an equal amount of $V$, for example, may differ by a factor of 3 in their organic C content. Sorption is an important process affecting the minor-element content of shales, and the chemical characteristics of the environment of accumulation and diagenesis of the clay minerals and organic matter are the most important factors controlling this process.Author's abs., condensed.

00279 Tourtelot, H. A.; Schultz, L. G.; Gill, J. R. Stratigraphic variations in mineralogy and chemical composition of the Pierre Shale in South Dakota and adjacent parts of North Dakota, Nebraska, Wyoming, and Montana, in Short papers in the geological sciences: U.S. Geol. Survey Prof. Paper 400-B, p. B447-B452, 1960.

Data on the Cretaceous Pierre Shale, based on about 100 measured sections, 700 electric and gamma-ray logs, X-ray mineralogic analyses of 500 samples, and chemical and spectrographic analyses of 69 samples, apply to about $100,000 \mathrm{sq} \mathrm{mi}$. Sharon Springs and Mitten Black Shale Members contain as much as 15 percent organic matter. Samples with more than 1 percent organic $\mathrm{C}$ have highest mean contents of $\mathrm{V}, \mathrm{Cu}, \mathrm{As}, \mathrm{Se}, \mathrm{Mo}$, and $\mathrm{U}$, although some standard deviations overlap those of other sample groups. Organic-rich samples tend to have highest contents of $\mathrm{B}, \mathrm{Cr}$, and $\mathrm{Zn}$. Average minor-element contents in shales, $\mathrm{C}$ content $>1$ percent, are (arithmetic mean, standard deviation in parentheses, in ppm): B 145 (34), Sc 21 (5), Ti 3,500 (540), V 400 (180), Cr 125 (27), Mn 175 (100), Co 14 (7), Ni 45 (24), Cu 80 (33), Zn 150 (96), Ga 17 (4), As 31 (15), Se 15 (12), Sr 115 (54), $\mathrm{Zr}$ 210 (62), Mo 20 (20), Ba 630 (210), Pb 19 (7), U 12 (8); isolated high values included: Mn 260 (340), Ni 53 (39), As 69 (120), Se 33 (47), Mo 43 (90).-EBT

00282 Tourtelot, H. A.; Huffman, Claude, Jr.; Rader, L. F. Cadmium in samples of the Pierre Shale and some equivalent stratigraphic units, Great Plains region, in Short papers in geology and hydrology: U.S. Geol. Survey Prof. Paper 475-D, p. D73-D78, 1964.

Cd content of 84 samples ( 10 of bentonite, 66 shale and claystone, and 8 marlstone) averages $1.4 \mathrm{ppm}$ and ranges from $<0.3$ to $11.0 \mathrm{ppm}$. The median value of 0.8 ppm probably represents $\mathrm{Cd}$ content of the average shale. Some samples with high Cd contain relatively large amounts of organic matter which may serve as a collector for $\mathrm{Cd}$. Other $\mathrm{Cd}$-high samples, however, contain little organic matter, which 
suggests possible variation in amount of available $\mathrm{Cd}$ in the sea water in which deposition occurred. Contents in 21 shale and claystone samples, organic $\mathrm{C}$ content

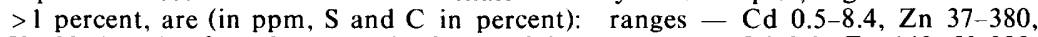
$\mathrm{V} 130-470, \mathrm{~S}<0.1-13.5$, organic C 1.1-10.3; averages $-\mathrm{Cd} 2.0, \mathrm{Zn} 140, \mathrm{~V} 390$, $\mathrm{S} 2.1$, organic $\mathrm{C} 3.5$; medians $-\mathrm{Cd} 1.2, \mathrm{Zn} 130, \mathrm{~V} 390, \mathrm{~S} 1.2$, organic $\mathrm{C} \mathrm{3.1.-}$ Authors' abs., modified.

00283 Tourtelot, H. A. Radioactivity and uranium content of some Cretaceous shales, central Great Plains: Am. Assoc. Petroleum Geologists Bull., v. 40, no. 1, p. 62$83,1956$.

The Sharon Springs Member of the Pierre Shale of Late Cretaceous age, a hard black organic-rich shale, similar in many characteristics to the Chattanooga Shale, is radioactive throughout central and western South Dakota, most of Nebraska, northern Kansas, and northeastern Colorado. In the Missouri River valley, thin beds of the shale contain as much as $100 \mathrm{ppm}$ U. Beds correlated with the Sharon Springs are as much as 20 feet thick and have a radioactivity of about $100 \mathrm{ppm}$ $\mathrm{eU}$ in southwestern Nebraska according to interpretation of gamma-ray well logs. The shale also contains interesting amounts of $\mathrm{As}, \mathrm{B}, \mathrm{Cr}, \mathrm{Cu}, \mathrm{Mo}, \mathrm{Ni}$, Se and V. $\mathrm{Mo}$ and $\mathrm{Sn}$ are less abundant in the Sharon Springs than in similar shales of Paleozoic age; $\mathrm{Ag}$ and $\mathrm{Se}$ are more abundant. Semiquantitative spectrographic analyses of 2 samples from the Niobrara Formation and 4 from the Sharon Springs show the following maximum ranges (in ppm): Be $1-5, \mathrm{~B} 100-5,000, \mathrm{Sc} \mathrm{5-50,Ti}$ $500-10,000, \mathrm{~V} 100-1,000, \mathrm{Cr} 50-500$, Mn 50-1,000, Co $5-50$, Ni $50-500$, Cu 50 $5,000, \mathrm{Zn}<50-500, \mathrm{Ga} 10-100, \mathrm{Sr} 50-500, \mathrm{Y}<10-100, \mathrm{Zr} 10-100$, Mo $10-500$, $\mathrm{Ag}<1-50, \mathrm{Sn}<\mathrm{i0}-50$, Ba 500-5,000, La nd, $\mathrm{Yb}<1-10$, Pb 10-500, U 5-500; of 1 sample of Big Stone Gap Shale (Mississippian), 1 of a Devonian shale, and 6 of the Chattanooga Shale (Devonian): Be 1-10, B 100-1,000, Sc 10-50, Ti 1,000 10,000 , V 50-5,000, Cr 50-1,000, Mn 50-500, Co 10-500, Ni 100-5,000, Cu 100 $5,000, \mathrm{Zn}<50-500$, Ga $10-100$, Sr 50-500, Y 50-100, Zr 10-500, Mo $100-5,000$, $\mathrm{Ag}<1-5$, Sn 10-100, Ba 500-5,000, La $<10-500$, Yb 5-10, Pb 10-500, U 10-500.Author's abs., modified.

00410 Tourtelot, H. A. Preliminary investigation of the geological setting and chemical composition of the Pierre Shale, Great Plains region: U.S. Geol. Survey Prof. Paper 390, 74 p., 1962.

The chemical, mineralogical and some physical properties of the Pierre Shale of Late Cretaceous age and equivalent rocks were studied. Samples are from widely separated localities in Montana, Wyoming, and South Dakota. Minor elements, determined by semiquantitative spectrographic analysis, showed narrow ranges of concentration (in ppm): Be 1.5-3, B 15-150, Sc 7-30, Ti 1,500-3,000, V 70-300, Cr 30-150, Mn 30-7,000, Co 3-30, Ni 7-150, Cu 15-70, Ga<1.5-15, Sr 70-700, Y 15-30, Zr 70-150, Nb nd-15, Mo nd-70, Ag nd-1.5, Ba 150-1,500, La 30-70, Ce 70-150, $\mathrm{Nd}$ nd-70, $\mathrm{Yb}$ 1.5-7, $\mathrm{Pb} 7-30$. Compared to generally accepted crustal abundance values, B, Sc, La, and $\mathrm{Ce}$ are enriched and $\mathrm{Na}, \mathrm{Ca}, \mathrm{Cr}, \mathrm{Mn}, \mathrm{Fe}, \mathrm{Sr}, \mathrm{Y}$, and $\mathrm{Nb}$ are depleted in the samples. Compared to samples from an organic-rich unit at the base of the Pierre, the nonorganic-rich samples contain more $\mathrm{Mg}$ and $\mathrm{Ga}$, probably more $\mathrm{Sr}$ and $\mathrm{Ba}$, and less $\mathrm{B}, \mathrm{V}, \mathrm{Ni}, \mathrm{Cu}, \mathrm{Mo}, \mathrm{As}$, and Se.-EBT

00280 Trask, P. D. The origin of the ore of the Mansfeld Kupferschiefer, Germany. A review of the current literature: Econ. Geology, v. 20, no. 8, p. 746-761, 1925.

The Kupferschiefer, a black bituminous shale of Late Permian age, averages 3 percent $\mathrm{Cu}$ over wide areas, but throughout most of the formation, $\mathrm{Cu}$ is either absent or in insignificant amounts. The Kupferschiefer sea covered an area of at least 22,500 square miles in Germany, but its deposits rarely exceed $1 \mathrm{~m}$ in thickness. Bitumen content ranges from 5 to 20 percent. In the Mansfeld district the Kupferschiefer averages $150 \mathrm{ppm} \mathrm{Ag;} \mathrm{generally} \mathrm{Ag}: \mathrm{Cu}$ ratio is 1:200. The average composition of shale mined in the Mansfeld region in 1911 is (in percent): $\mathrm{SiO}_{2}$ 32.41, $\mathrm{Al}_{2} \mathrm{O}_{3}$ 12.89, $\mathrm{CaO} 11.03, \mathrm{MgO} 3.69, \mathrm{Cu} 3.24, \mathrm{Ag} \mathrm{0.018}, \mathrm{Pb} \mathrm{0.59,} \mathrm{Zn} 1.85$, $\mathrm{Fe} 2.87, \mathrm{~S} 2.61, \mathrm{SO}_{2} 0.61, \mathrm{CO}_{2} 10.49$, C in bitumen 8.75 , water soluble constituents, chiefly gypsum, 1.55, water soluble Cl 0.13 , and moisture 0.77 . Short summaries of previously published discussions on the origin of the ore and older analyses are included as is a large bibliography.-EBT

00281 Tschanz, C. M.; Laub, D. C.; Fuller, G. W. Copper and uranium deposits of the Coyote district, Mora County, New Mexico: U.S. Geol. Survey Bull. 1030 L. p. 343-398, 1958 . 
$\mathrm{Cu}$ and $\mathrm{U}-\mathrm{V}$ deposits in Coyote district, New Mexico, are in the lower 2,000 feet of the Pennsylvanian and Permian(?) Sangre de Cristo Formation and consist of small isolated lenses of $\mathrm{Cu}$-bearing carbonaceous sediments interbedded with mainly red rocks at 12 or more stratigraphic levels. The better deposits, in carbonaceous shale, average about 2 percent $\mathrm{Cu}$. Chalcocite replaces wood and forms nodules that contain small and variable amounts of pyrite, bornite, covellite, and, rarely, uraninite. The metals were probably derived from Precambrian granites; the U and $\mathrm{V}$ from earlier, low-grade, syngenetic deposits. $\mathrm{Cu}$ and minor $\mathrm{U}$ were deposited in local stagnant basins by reaction with $\mathrm{H}_{2} \mathrm{~S}$ and decaying organic material. The uraniferous shale and $\mathrm{Cu}$ deposits are probably syngenetic, or nearly so, but the $\mathrm{U}$ deposits in sandstone are epigenetic, probably deposited by ground waters with possible hydrothermal admixture. Semiquantitative spectrographic analyses of 2 samples of black carbonaceous shale with chalcocite nodules show (in percent, $0 . X_{+}$, 0.464 to $1.0 ; 0 . \mathrm{X}, 0.215$ to $0.464 ; 0 . \mathrm{X}-, 0.100$ to 0.215 ): $\mathrm{V}<0.1$ to $0.0 \mathrm{X}-, \mathrm{Pb} 0.00 \mathrm{X}$, Ba $0.0 \mathrm{X}$ - to $0.0 \mathrm{X}$, Ti $0 . \mathrm{X}-$ to $0 . \mathrm{X}, \mathrm{Mn} 0.0 \mathrm{X}-$, Cr $0.00 \mathrm{X}+, \mathrm{Co} 0.000 \mathrm{X}+, \mathrm{Ni} 0.00 \mathrm{X}$, $\mathrm{Ag} 0.000 \mathrm{X}$, Mo 0 , Zn $0, \mathrm{Zr} 0.00 \mathrm{X}+, \mathrm{B} 0.00 \mathrm{X}-$, Sr $0.00 \mathrm{X}$, Ga $0.00 \mathrm{X}-$ to tr, Sc $0.00 \mathrm{X}-$, Ce 0 , La 0 to $\mathrm{tr}, \mathrm{Nd} 0, \mathrm{Sm} 0, \mathrm{Y} 0.00 \mathrm{X}-$ to $0.00 \mathrm{X}$, Dy $0, \mathrm{Er} 0$, Gd 0 , $\mathrm{Yb} 0.00 \mathrm{X}-, \mathrm{Be} 0.000 \mathrm{X}$; chemical analyses showed $\mathrm{U} 0.005$ to $0.004, \mathrm{Cu} 2.38$ to 2.63.-Authors' abs., modified.

00353 Tugarinov, A. I.; Vaynshteyn, E. E. Redkiye zemli v gornykh porodakh [Rare earths in rocks (in Russian; English abs.)]: Internat. Geol. Cong., 21 st, Copenhagen, 1960, Doklady Sovetskikh Geologov, Pt. 1, p. 65-77, 1960 [As seen in translation by Michael Fleischer, 1962, written commun.].

The study of rare earth distribution in sedimentary rocks has shown that clayey deposits concentrate both yttrium and cerium earths; yttrium earths predominate in phosphates and cerium earths in carbonate sediments. Phosphorites of Paleogene age from Kazakhstan showed the following rare earth ratios: La:Nd 1.15, Ce:Nd 1.5, Pr:Nd 0.23, Sm:Nd 0.24, Gd:Nd 0.23, Tb:Nd 0.06, Dy:Nd 0.3, Er:Nd 0.13, $\mathrm{Yb}: \mathrm{Nd} 0.33$, and $\mathrm{Y}: \mathrm{Nd} 2.08$. Clays of Paleogene age from Kazakhstan showed the following ratios (2 analyses given): La: Nd 0.2, 1.1; Ce:Nd 0.6, 2.0; Pr:Nd 0.19, 0.23: Sm:Nd 0.5, 0.23; Gd:Nd 0.35, 0.12; Tb:Nd 0.10,--; Dy:Nd 0.42, 0.15; Er:Nd $0.12,0.04 ; \mathrm{Yb}: \mathrm{Nd} 0.08,0.05$; and $\mathrm{Y}: \mathrm{Nd} \mathrm{1.2,0.55.-EBT}$

Turanskaya, N.V. See Balashov, Yu. A. 00024

Turekian, K. K. See Carr, M. H. 00065

00350 Turekian, K. K.; Feely, H. W. Variations in the abundance of trace elements in a eupelagic Atlantic core [abs.]: Geol. Soc. America Bull., v. 67, no. 12, pt. 2, p. $1739,1956$.

Chemical and spectrographic analyses of a eupelagic Atlantic core, A180-76, show that generally amounts of $\mathrm{Mg}, \mathrm{Cu}, \mathrm{Ni}$, and $\mathrm{Cr}$ are direct functions of the percent lutite fraction: $\mathrm{Pb}$ and $\mathrm{Sr}$ do not fluctuate with the lutite fraction. The core averages 78.3 percent $\mathrm{CaCO}_{3} ; \mathrm{Pb}$ and $\mathrm{Sr}$ are probably associated with the carbonate. Concentrations of $\mathrm{Cu}, \mathrm{Ni}$, and $\mathrm{Mg}$ occur where either a greenish hue was seen or where diatoms are abundant. These concentrations are perhaps related to their presence in porphyrin-type compounds, but the compounds are not a major method of removal of trace elements from the sea. Average composition of the core is

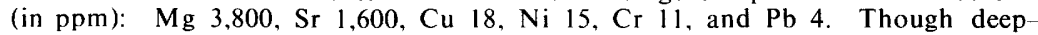
sea plankton concentrate minor elements in their tissues, it is evident that in most cases they are not incorporated in deep-sea sediments.-Authors' abs., condensed.

00351 Turekian, K. K.; Kulp, J. L. The geochemistry of strontium: Geochim. et Cosmochim. Acta, v. 10, p. 245-296, 1956.

Approximately 700 analyses have been made of silicate rocks and 300 analyses of carbonate materials for $\mathrm{Sr}$. A representative sampling of the earth's crust was attempted. "Average" shale (5 percent $\mathrm{Ca}$ ) averaged about $300 \mathrm{ppm} \mathrm{Sr}$ in 69 samples. Noncalcareous (average 0.4 percent $\mathrm{Ca}$ ) shales contained an average of $245 \mathrm{ppm} \mathrm{Sr}$. The $\mathrm{Sr} / \mathrm{Ca}$ ratio in the sea seems to have been increasing with time, in part due to the appearance of $\mathrm{CaCO}_{3}$ depositing organisms, but probably mainly due to changes in the kinds of rock exposed to weathering.-EBT

00352 Turekian, K. K.; Tausch, E. H. Barium in deep-sea sediments of the Atlantic Ocean: Nature, v. 201, p. 696-697, 1964.

Ba concentration in the tops of north and equatorial cores raised by the Lamont

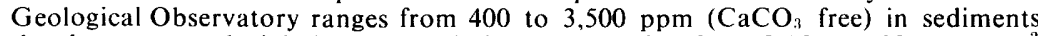
that have a postglacial clay accumulation rate ranging from 0.15 to $1.08 \mathrm{~g} \mathrm{per} \mathrm{cm}^{2}$ 
per 1,000 years. The concentrations of $\mathrm{Ba}$ in deep-sea sediments correlate with surface biological productivity.--EBT

00354 Turekian, K. K.; Wedepohl, K. H. Distribution of the elements in some major units of the earth's crust: Geol. Soc. America Bull., v. 72, no. 2, p. 175-191, 1961.

A table of abundances of elements in various major units of the earth's lithic crust is presented with documentation of sources and discussion of the choice of units and data. Abundances in shale and deep-sea clay are, respectively, (in ppm): Li

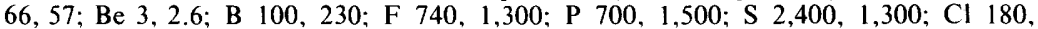
21,000; Sc 13, 19; Ti 4,600, 4,600; V 130, 120; Cr 90, 90; Mn 850, 6,700; Co 19, 74; Ni 68, 225; Cu 45, 250; Zn 95, 165; Ga 19, 20; Ge 1.6, 2; As 13, 13; Se 0.6,

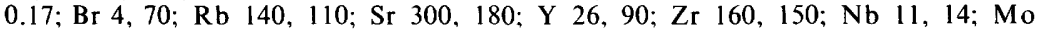
2.6, 27; Ag 0.07, 0.11; Cd 0.3, 0.42; In 0.1, 0.08; Sn 6, 1.5; Sb 1.5, 1; I 2.2, 0.05 ; Cs 5, 6; Ba 580, 2,300; La 92, 115; Ce 59, 345; Pr 5.6, 33; Nd 24, 140; Sm 6.4, 38; Eu 1, 6; Gd 6.4, 38; Tb 1, 6; Dy 4.6, 27; Ho 1.2, 7.5; Er 2.5, 15; Tm 0.2, 1.2; Yb 2.6, 15; Lu 0.7, 4.5; Hf 2.8, 4.1; Ta 0.8, 0.X; W 1.8, X; Au 0.00X, 0.00X; Hg 0.4, 0.X: T1 1.4, 0.8; Pb 20, 80; Th 12, 7; U 3.7, 1.3; major elements, rare gases, elements for which data are lacking, and non-naturally occurring elements omitted.EBT

00346 Ugolini, F. C.; Tedrow, J. C. F.; Grant, C. L. Soils of the northern Brooks Range, Alaska. 2. Soils derived from black shale: Soil Sci., v. 95, no. 2, p. 115 $123,1963$.

A unique soil developed from black carbonaceous shale in the undifferentiated Sadlerochit (Permian) and Shublik (Triassic) Formations in northern Alaska is described. Major-element composition of this massive argillaceous shale is similar to average shale composition, but the trace-element content differs. $\mathrm{Ba}, \mathrm{V}, \mathrm{Zn}$, and, to a lesser extent, $\mathrm{Cr}$ and $\mathrm{Cu}$ contents are higher than those of normal shale. $\mathrm{Cr}, \mathrm{Ga}, \mathrm{Mn}, \mathrm{V}$, and $\mathrm{Zn}$ are concentrated in carbonaceous samples; $\mathrm{Ni}, \mathrm{Sn}$, and $\mathrm{Sr}$ are in samples rich in carbonates, phosphate, and gypsum. Minor element composition of soft black shale is (in ppm): $\mathrm{Ba} \mathrm{1,310,} \mathrm{Co} \mathrm{6,} \mathrm{Cr} 408, \mathrm{Cu} \mathrm{134,} \mathrm{Ga}$ 8.2, Mn 142, Mo 5.2, Ni 159, Sn 0.35, Sr 172, V 845, Zn 1,680; in hard black shale: $\mathrm{Ba} 1,120, \mathrm{Co} 6.2, \mathrm{Cr} 281, \mathrm{Cu} 155, \mathrm{Ga} 0.85, \mathrm{Mn} 75, \mathrm{Mo}--, \mathrm{Sn} 1.8, \mathrm{Sr}$ 282, V 160, Zn 665; in 3 random samples from area: Ba 1,540-2,130, Co 14-27, Cr 16-91, Cu 34-87, Ga 15-27, Mn 430-1,090, Ni 189-305, Sn 2.5-3.4, Sr 34-49, V 111-232, Zn 2,630-2,920, all spectrochemical analyses.-- EBT

00347 Varley, Thomas. Bureau of Mines investigates gold in oil shales and its possible recovery: U.S. Bur. Mines Rept. Inv. 2413, 10 p., 1922.

It was concluded that $\mathrm{Au}$ in oil shales can be determined accurately by the ordinary accepted fire assay method. All dangers of loss of precious metals with organic matter can be avoided by removing the organic matter with chromic acid. Decarbonized oil shale from the Green River oil shale in Wyoming assayed 0.03 oz per ton or about $1 \mathrm{ppm}$. Recalculated to raw shale (30 percent shrinkage) this is $0.021 \mathrm{oz}$ per ton or about $0.7 \mathrm{ppm}$. A sample of oil shale from Soldiers Summit, Utah, assayed $0.02 \mathrm{oz}$ per ton in decarbonized shale $(0.7 \mathrm{ppm})$ or $0.014 \mathrm{oz}$ per ton $\mathrm{Au}(0.5 \mathrm{ppm})$ in raw shale.-EBT

Vaynshteyn, E. E. See Tugarinov, A. I. 00353

00409 Vesterberg, K. Alb. Undersökningar över Alunskiffer [Investigation of Alum shale (in Swedish; English summ.)]: Ingeniörsvetenskapsakademiens Handl., v. 62, p. $7-47,1927$.

Silicate analyses of alum shale ash for major-element oxides and determinations of loss on heating and loss on ignition are reported. A sample of alum shale from the base of Silurian limestone from Limensgade, Bornholm, showed the following contents of minor-element oxides (in ppm): $\mathrm{PbO} 43.3, \mathrm{CuO} 62.9, \mathrm{ZnO}--, \mathrm{Co}_{3} \mathrm{O}_{4}$ 1.4, $\mathrm{NiO} 56.3, \mathrm{Mn}_{3} \mathrm{O}_{4} 3.678, \mathrm{Cr}_{2} \mathrm{O}_{3}--, \mathrm{V}_{2} \mathrm{O}_{5} 577, \mathrm{TiO}_{2} 3,280, \mathrm{ZrO}_{2}--$. In 2 samples of graptolite shale, younger than the alum shale, from Vasagaard, Bornholm, the following contents were found: $\mathrm{PbO}$ 54.7, 34.8; $\mathrm{CuO} 116.2,140 ; \mathrm{ZnO} 18.9,4.8$; $\mathrm{Co}_{3} \mathrm{O}_{4} 23.7,17.8 ; \mathrm{NiO} 85.9,24.6 ; \mathrm{Mn}_{3} \mathrm{O}_{4} 152.9,218.2 ; \mathrm{Cr}_{2} \mathrm{O}_{3} 131.5,139 ; \mathrm{V}_{2} \mathrm{O}_{5} 5.9$, 18.9; $\mathrm{TiO}_{2} 688.8,2,980 ; \mathrm{ZrO}_{2}$ ?, 21.0.-EBT

00348 Vine, J. D. Metals in Pennsylvanian black shale from Kentucky and Indiana [abs.]: Geol. Soc. America Spec. Paper 82, p. 212, 1964. 
Black shale beds of Pennsylvanian age in western Kentucky contain the same rare metals as black shale of similar age in Indiana described by Zangerl and Richardson (1963). They commonly contain more than $1,000 \mathrm{ppm} \mathrm{V}$ and $\mathrm{Zn}$, and as much as $1,000 \mathrm{ppm} \mathrm{Mo}$ and $\mathrm{Ni}, 500 \mathrm{Cr}, 300 \mathrm{Cu}, 100 \mathrm{~Pb}, 70 \mathrm{Y}$ and $\mathrm{La}, 20 \mathrm{Co}$, and 10 Ag. Analyses of individual laminae from a bed in Indiana show maximum metal content in black laminae rich in fish remains, but not in equally black laminae that contain only marine invertebrates. Exceptions are $\mathrm{V}$ and $\mathrm{Cr}$, which are most abundant in dark-gray laminae, and $\mathrm{Pb}$, which increases toward the top of the bed. A syngenetic origin is indicated by stratigraphic and fossil control and wide distribution of deposits. The ultimate source of the metals, whether marine or terrestrial, is unknown.-JDV

00327 Vinogradov, A. P.; Ronov, A. B. Sostav osadochnykh porod russkoy platformy $v$ svyazi $s$ istoriyey ee tektonicheskikh dvizheniy [Composition of sedimentary rocks in the Russian platform in relation to the history of their tectonic movements]: Geokhimiya, no. 6, p. 3-24, 1956; English translation: Geochemistry, no. 6, p. $533-559,1956[1960]$.

Comparisons between rocks of the Russian platform and rocks of other platforms show that variations in element contents have had a general trend during geologic time; that is, they indicate an evolution of the material of the sedimentary mantle and the rocks that compose it. $\mathrm{Ni}, \mathrm{Co}$, and $\mathrm{Cu}$ become threefold less abundant upward in the stratigraphic column. These changes parallel a decrease in amounts of $\mathrm{Fe}$ and $\mathrm{Mg}$ bound in silicates. The average chemical composition of the clays of the Russian platform by age is shown. The overall composition is: (in percent) $\mathrm{SiO}_{2} 50.65, \mathrm{Al}_{2} \mathrm{O}_{3} 15.10, \mathrm{Fe}_{2} \mathrm{O}_{3} 6.47, \mathrm{TiO}_{2} 0.78, \mathrm{CaO} 7.19 \mathrm{MgO} 3.31, \mathrm{~K}_{2} \mathrm{O} 3.49$, $\mathrm{Na}_{2} \mathrm{O} 0.8, \mathrm{CO}_{2} 6.10$, loss on ignition 5.58, (in ppm) Th $11, \mathrm{U} 4.1$, Co 11 , Ni 22, and $\mathrm{Cu} 35 .-\mathrm{EBT}$

00345 Vinogradov, A. P. Geokhimiya redkikh i rasseyannykh khimicheskikh elementov $\mathrm{v}$ pochvakh [Geochemistry of rare and dispersed chemical elements in soils]: Moscow, Isd-vo, Akad. Nauk SSSR, 237 p., 1957; English translation: New York, Consultants Bur., Inc., 209 p.

Data on minor elements in rocks from which soils are derived are also included. Much of the discussion on the geochemical behavior of elements is indirectly pertinent to black shales. The table of minor-element contents in different rock types (Vinogradov, 1956) is included. New data include rare-earth element contents; average contents in shales are (in ppm): La 19, Ce 46, Pr 5.5, Nd 23, Sm 6.5, Eu 1, Gd 6.5, Tb 0.9, Dy 4.5, Ho 1, Er 2.5, Tm 0.2, Yb 3, Lu 0.7, and Y 28. In marine clays, B content is $500 \mathrm{ppm}$.- EBT

00349 Vinogradov, A. P. Zakonomernosti raspredeleniya khimicheskikh elementov Zemnoy kore [Regularity of distribution of chemical elements in the Earth's crust (in Russian: English summ., p. 1)]: Geokhimiya, no. 1, p. 6-52, 1956; English translation: Geochemistry, no. 1, p. 1-43, 1956 [1960].

The chemical composition of the principal rock types, including ultrabasic to acid igneous rocks, clays, and shales, and the silicate phase of chondrites, has been critically examined. For the principal constituents ( $\mathrm{Si}, \mathrm{Al}, \mathrm{Fe}, \mathrm{Ti}, \mathrm{Mg}, \mathrm{Ca}, \mathrm{K}, \mathrm{Na}$, $\mathrm{P} . \mathrm{Mn}($ and $\mathrm{O}))$ the weighted mean has been calculated from published data and the author's data for the rocks of Russia; for clays and shales, from published data and from the author's data for clays of all ages of the Russian platform. For rarer and more scattered elements, arithmetic averages have been calculated. A table showing the source of all data is given. The average composition of clays and shales is (in ppm; no explanation given for the parentheses): $\mathrm{Li} 60, \mathrm{Be} 7, \mathrm{~B} 12$, F $500, \mathrm{Cl} 160$, Sc 10, Ti 4,500, V 130, Cr 160, Mn 670, Co 23, Ni 95, Cu 57, $\mathrm{Zn} \mathrm{80,} \mathrm{Ga} \mathrm{40,} \mathrm{As} \mathrm{6.6,} \mathrm{Ge} \mathrm{7,} \mathrm{Se} \mathrm{0.6,} \mathrm{Br} \mathrm{6,} \mathrm{Rb} \mathrm{400,} \mathrm{Sr} \mathrm{450,} \mathrm{Y} \mathrm{33,} \mathrm{Zr} \mathrm{200,} \mathrm{Nb} \mathrm{20,}$ Mo 2, Ru --, Rh --, Pd --, Ag (0.9), Cd 0.3, In --, Sn 30, Sb 30, Te --, I I, Cs 12, Ba 800, La 40, Ce 30, Pr 5, Nd 18, Pm?, Sm 5, Eu 1, Gd 5, Tb 0.9, Dy 4, Ho (1), Er 2.5, Tm (0.2), Yb 2.2, Lu (0.2), Hf (4), Ta 3.5, W--, Re --, Os Ir - Pt Ra $1 \times 10^{-6}$, Ac $6.8 \times 10^{-10}$, Th 11 , Pa $1.1 \times 10^{-6}$, U 3.2. - EBT 
Volkov, I. I. See Ostroyumov, E. A. 00246

00341 Vorob'ev, G. G. Galliy $\mathbf{v}$ mineralakh i gornykh porodakh Mongolii [Gallium in minerals and rocks of Mongolia]: Geokhimiya, no. 8, p. 713-722, 1957; English translation: Geochemistry, no. 8, p. 835-846, 1957 [1960].

Ga content in minerals and rocks of Mongolia was determined by a spectral method. Isomorphous replacement of $\mathrm{Al}, \mathrm{Fe}$, and $\mathrm{Zr}$ by $\mathrm{Ga}$ has been established. In the process of replacement, $\mathrm{Ga}$ shows antagonism toward $\mathrm{V}$ and some parallelism with $\mathrm{Ge}$. Mongolian granites are enriched in $\mathrm{Ga}$ in comparison with other granites and a part of the $\mathrm{Ga}$ passes from the contact zones of the granites into the host rocks. $\mathrm{Ga}$ content in Mongolian sedimentary rocks is normal. Ga content in combustible shales averaged $30 \mathrm{ppm}$ with a maximum of $50 \mathrm{ppm}$ for two samples.-Author's abs., modified.

00342 Wakeel, S. K. El; Riley, J. P. Chemical and mineralogical studies of deep sea sediments: Geochim. et Cosmochim. Acta, v. 25, p. 110-146, 1961.

Chemical and spectrographic analyses are presented for major and minor elements in 10 calcareous, 12 argillaceous, and 3 siliceous deep-sea sediments from the Atlantic, Pacific, and Indian Oceans and the Mediterranean Sea; 3 deep sea volcanic sediments: an unusual manganiferous ooze; and the $<2 \mu$ fractions from 2 nearshore muds. Average contents in deep-sea sediments are (in ppm): calcareous, $\mathrm{Sr} 1,110$, Ba 1,360, Cu 338, Pb 150, Co 91, Ni 232, Ga 12, La 100, Sn 18, Ge 1.2, Zr 140, Hf 3, V 300, Cr 51, Mo 20; argillaceous, Sr 450, Ba 2,000, Cu 400, Pb 175, Co 100, Ni 300, Ga 20, La 90, Sn 20, Ce 130, Ge 2.5, Zr 126, Hf 6, Th 19, V 390 , Cr 55. Mo 17: siliceous, Sr 230, Ba 1.050, Cu 370, Pb 180, Co 200, Ni 330, Ga 18, La 80, Sn 12, Zr 170, V 460, Cr 97, Mo 38. Nearshore mud contained $(<2 \mu$ fractions): Sr 550, 920; Ba 960, 1,300; Cu 460, 420; Pb 230; Co 0; Ni 27, 31: Ga 17, 15: Sn 20, 23; Zr 80, 210; V 480, 680; and $\mathrm{Cr} 220$, 300.-Authors' abs., modified.

Walsh, T. See Fleming, G. A. 00123

00343 Walsh, T.; Fleming, G. A. Selenium levels in rocks, soils and herbage from a high selenium locality in Ireland: Internat. Soc. Soil Sci., Comm. 2 and 4, Trans., v. 2, p. 178-183, 1952 [1953]; also in Soils and Fertilizers, v. 17, 10 p. [1954].

An account of some aspects of Se toxicity which have been identified with an Irish soil series is presented. Among local rocks examined, pyritiferous shale showed $28.2 \mathrm{ppm} \mathrm{Se}$. Data are also given for the Se content of soils and herbage species from affected and nearby nonaffected areas.-Authors' summ., condensed.

00338 Wardani, S. A. El. Marine geochemistry of germanium and the origin of Pacific pelagic clay minerals: Geochim. et Cosmochim. Acta, v. 15, p. 237-254, 1958.

Ge content of sea water is $0.05 \mathrm{ppb}$. The most abundant organisms in the sea do not take up detectable amounts of Ge. Pacific northeast equatorial eupelagic clays contain $2 \mathrm{ppm} \mathrm{Ge}$; shelf sediments, standard marine clay minerals, and south equatorial eupelagic clays contain $1 \mathrm{ppm}$. Aluminosilicates contain most of the $\mathrm{Ge}$ in clays, and partial removal of $\mathrm{Ge}$ from sea water occurs during hydrogenous growth of such minerals in sea water. The geochemical fractionation between shelf and deep-sea sediments suggests that shelf sediments and Pacific south equatorial pelagic clays are primarily lithogenous in origin. In the Pacific northeast equatorial eupelagic clays the coarse fraction is primarily lithogenous in origin but the claymineral size fraction is rich in hydrogenous clay minerals.-Author's abs., condensed.

00344 Wardani, S. A. El. On the geochemistry of germanium: Geochim. et Cosmochim. Acta, v. 13, p. 5-19, 1957.

Estimates of the abundance of Ge have been lowered to about $10 \mathrm{ppm}$ for the cosmos and $1 \mathrm{ppm}$ for the earth's crust. Concentration in granites, basalts, and gabbros is consistently about $1 \mathrm{ppm}$. Ge is classified among the less volatile elements. Although analyzed shales average $1.1 \mathrm{ppm} \mathrm{Ge}$, it is very difficult to calculate an average for all shales due to their strong variation in Ge content depending on 
type and organic content. A sample of Chattanooga Shale showed $16.6 \mathrm{ppm}$ Ge. For the present, average Ge content in shales is estimated as twice that of igneous rocks. Some Ge contents in shales are (in ppm): composite sample (3) St. Croix Falls, Wis., 0.8; Glenwood Shale, Minn., 1.6, 1.5; Cambrian shale, St. Croix Falls, 1.5; pyritic shale, St. Croix Falls, 0.8; Cretaceous clay, Minn.. 1.0, 1.1; and residual clay, Redwood Falls, Minn., 1.1.-EBT

00339 Warner, L. A.; Holser, W. T.; Wilmarth, V. R.; Cameron, E. N. Occurrence of nonpegmatitic beryllium in the United States: U.S. Geol. Survey Prof. Paper 318,198 p., 1959.

Average $\mathrm{BeO}$ content in the lithosphere is about $10 \mathrm{ppm}$. Be is dissipated during weathering and sedimentation, although it can be concentrated in residual deposits. Oil shales contain slightly more Be than phosphate rocks. A maximum of $40 \mathrm{ppm}$ $\mathrm{BeO}$ was found in the Helms Formation of Texas of Devonian age and the Chattanooga Shale of Tennessee of Devonian and Mississippian age, and in Eocene oil shale from California. Spectrographic analyses showed the following contents (in ppm): Eocene lignitic clay, Alabama, $\mathrm{BeO} 20, \mathrm{CoO} 30, \mathrm{NiO} 40, \mathrm{~V}_{2} \mathrm{O}_{5}, 2,000$; Eocene lignitic oil shale, California, $\mathrm{BeO} 40, \mathrm{Bi}_{2} \mathrm{O}_{3} 20, \mathrm{NiO} 10, \mathrm{SnO} 20, \mathrm{~V}_{2} \mathrm{O}_{5} 400$; Devonian and Mississippian shales, Tennessee (5 samples including Chattanooga Shale), BeO 20-40, CoO 40-80, $\mathrm{MoO}_{3}$ 30-100, NiO 80-400, U (I sample ) 120 , eU (4 samples) 30-206, $\mathrm{V}_{2} \mathrm{O}_{5}, 80-400$. Other analyses for $\mathrm{BeO}$ showed the Devonian and Mississippian shales average $10 \mathrm{ppm}$, the Helms Formation 20, and the Permian Phosphoria Formation of Idaho and Montana had a maximum of $10 \mathrm{ppm}$. - EBT

Washington, H.S. See Clarke, F. W. 00074

Weaver, C. E. See Adams, J. A. S. 00001

00340 Weber, J. N. Geochemistry of graywackes and shales: Science, v. 131, no. 3401, p. 664665,1960 .

Spectrographic analyses of 69 graywackes and 33 shales for 14 minor elements illustrate the variation in composition within a graywacke bed, between beds in one section, between sections, and between formations. No striking difference between the composition of graywackes and the average crustal rock was evident. Pelagic clays greatly differ from shales associated with graywackes in that the pelagic clays tend to be richer in $\mathrm{B}, \mathrm{Ba}, \mathrm{Cr}, \mathrm{Cu}, \mathrm{Ni}$, and $\mathrm{V}$, elements typical of hydrolyzate environments. Shales associated with turbidity currents contain less organic matter and more $\mathrm{Mg}, \mathrm{Mn}$, and Co. Spectrographic analyses show that the Ordovician Normanskill Shale associated with the Normanskill graywacke contained (in ppm): B 130, Ba 360, Co 32, Cr 87, Cu 37, Ga 20, Mn 400, Ni 58, Sc 15, Sr 150, Ti $7,000, \mathrm{~V} \mathrm{79}, \mathrm{Zr} \mathrm{230;}$ and 33 samples of miscellaneous shales, B 220, Ba 520, Co 22, $\mathrm{Cr} 110, \mathrm{Cu} 58, \mathrm{Ga} 13, \mathrm{Mn} \mathrm{180,} \mathrm{Ni} 64, \mathrm{Sc} 12, \mathrm{Sr} 150$, Ti 6,000, V $150, \mathrm{Zr}$ 340. - EBT

00328 Wedepohl, K. H. Untersuchungen zur Geochemie des Bleis [Investigations of the geochemistry of lead (in German; English abs.)]: Geochim. et Cosmochim. Acta, v. 10, p. 69-148, 1956; abs., Geol. Soc. America Bull., v. 67, no. 12, pt. 2, p. 1741 , 1956.

A quantitative spectrographic method ( 0.01 percent $\mathrm{Bi}$ standard) attains a sensitivity of $1 \mathrm{ppm} \mathrm{Pb}$ by relative concentration of light volatile elements with a doublearc instrument. More than 500 analyses of $\mathrm{Pb}$ in representative samples, including more than 250 new ones, are discussed. The behavior of $\mathrm{Pb}$ during rock alteration (weathering. mobilization, concentration, metamorphism) is examined. Factors for concentration are low solubility and action of organisms. Clay minerals contain most of the $\mathrm{Pb}$ in sediments. Relatively high contents of $\mathrm{Pb}, \mathrm{Zn}$, and $\mathrm{Cu}$ in pelagic sediments cannot have been entirely derived from continental weathering; a part is due to volcanic exhalations. $\mathrm{Pb}$ content in the bituminous Posidonienschiefer of the Lias $\epsilon$ ranges from 7 to $33 \mathrm{ppm}$. Analyses of other sediments show the following averages (ppm $\mathrm{Pb})$ : composite sample of 36 European Paleozoic shales 16, composite of 14 Japanese Paleozoic shales 27, composite of 10 Japanese Mesozoic shales 28 , nonpelagic argillaceous rocks 20 , Atlantic deep-sea clays 43 , and Pacific deep-sea clays 140.-A Athors' abs., modified 
00329 Wedepohl, K. H. Untersuchungen am Kupferschiefer in Nordwestdeutschland; Ein Beitrag zur Deutung der Genese bituminöser Sedimente [Investigation of the Kupferschiefer in northwest Germany; a contribution to the genesis of bituminous sediments (in German; English abs.)]: Geochim. et Cosmochim. Acta, v. 28, p. $305-364,1964 b$.

About 50 samples of the Kupferschiefer from cores in northwest Germany were analyzed and resultant data compared with that of ore-grade deposits near Mansfeld. Carbonate content in the brown-black, finely layered marl, $20-50 \mathrm{~cm}$ thick, is about 30 percent. $\mathrm{B}$ and $\mathrm{Rb}$ content is proportional to illite content; $\mathrm{V}$, $\mathrm{Cr}, \mathrm{Ni}$, and perhaps $\mathrm{Mo}$ and $\mathrm{Co}$ contents are related to $\mathrm{C}$ content, but no relation between sulfide content and $\mathrm{C}$ content could be detected. In the marl, $\mathrm{Cu}$ and $\mathrm{Ag}, \mathrm{Pb}$, and $\mathrm{Zn}$ occur in that order upward. In the northwest, where marine influence was strongest, the Kupferschiefer is comparable to other bituminous sediments. Syngenetic origin of the metals is most probable. Analyses of the core sample showed (in ppm): $\mathrm{B}$ nd-280, $\mathrm{C}$ nd-143,000, $\mathrm{CO}_{2}$ nd $-420,000, \mathrm{~S}$ nd-52,000, Ti nd $-8,600, \mathrm{~V}$ nd-5,000, $\mathrm{Cr}$ nd $-330, \mathrm{Mn} 110-6,000$, total $\mathrm{Fe} 11,000-98,000, \mathrm{Ni}$ $30-1,200$, Co nd-360, Zn 10-41,000, As nd-5,000, Rb nd-190, Sr nd-680, Ba nd5,400 , Mo nd-1,500, Pb 35-22,000.-Author's abs., modified.

00335 Wedepohl, K. H. "Kupferschiefer" and the problem of syngenetic ore deposition [abs.]: Geol. Soc. America Spec. Paper 82, p. 219-220, 1964a.

The Kupferschiefer is a thin-bedded bituminous marine marl or shale, about 1 foot thick, of early Late Permian age, exposed from England through Germany to Poland and containing local metal accumulations of economic grade (MansfeldSangerhausen and Silesia) which appear to be controlled by paleogeography. $\mathrm{Cu}$ $+\mathrm{Ag}_{-}, \mathrm{Pb}-$, and $\mathrm{Zn}-\mathrm{rich}$ layers occur in this sequence upward over large areas, which corresponds with the order of increasing solubility of the sulfides. Zoning must be controlled by $S$ availability in time and space from bacterial sulfate reduction in stagnant sea water. For the amount of metals present, additions from a red bed environment to the composition of the sea are assumed. The metal concentrations and relationships between $\mathrm{Mn}$ and calcite-dolomite and between $\mathrm{V}$, $\mathrm{Cr}, \mathrm{Ni},\left(\mathrm{Co}-, \mathrm{Mo}_{-}\right)$and organic $\mathrm{C}$ all point to special sea-water composition and syngenetic metal precipitation. No relation btween $\mathrm{S}$ and $\mathrm{C}$ and between ore meals and clay minerals could be detected.-A A thor's abs., condensed.

00336 Wedepohl, K. H. Spurenanalytische Untersuchungen an Tiefseetonen aus dem Atlantik [Trace analysis investigation of deep-sea clays from the Atlantic (in German: English abs.)]: Geochim. et Cosmochim. Acta, v. 18, p. 200-231, 1960.

Elements detected in 20 samples of Atlantic and Pacific deep-sea clays are grouped into 3 classes: (A) those having the same average abundances in nearshore and pelagic clays: $\mathrm{Ti}, \mathrm{V}, \mathrm{Cr}, \mathrm{Ga}, \mathrm{Rb}$, and $\mathrm{Zr}$. (B) those enriched in Pacific clays: $\mathrm{La}, \mathrm{Sc}, \mathrm{Y}$, and $\mathrm{Ba}$. (C) those which increase from nearshore to Atlantic to Pacific clays: $\mathrm{Zn}, \mathrm{Ni}, \mathrm{Pb}, \mathrm{Cu}, \mathrm{Co}, \mathrm{Mn}$, and $\mathrm{Mo}$. Behavior of group $\mathrm{A}$ suggests that submarine weathering of volcanics and pyroclastics is not important. Behavior of group B may result from organic contributions and diagenesis. Behavior of group $C$ may be caused by differential rates of accumulation in the two oceans. As computed from the author's previously unpublished data and from the literature, average trace-element contents of clays from the Atlantic are (in ppm): Sc 13, Ti 5,100, V 140, Cr 86, Mn 4,000, Co 38, Ni 140, Cu 130, Zn 130, Ga 19, Rb 120, $\mathrm{Sr} 120$ (carbonate free), Y 29, $\mathrm{Zr} 130, \mathrm{Mo} \mathrm{9,} \mathrm{Ba} \mathrm{700,} \mathrm{La} \mathrm{98,} \mathrm{Pb} \mathrm{45;} \mathrm{from}$ nearshore, Sc 13, Ti 4,600, V 130, Cr 100, Mn 850, Co 13, Ni 55, Cu 48, Zn 95. $\mathrm{Ga} 19, \mathrm{Rb} 130, \mathrm{Sr}<250$, Y 27, $\mathrm{Zr} 160, \mathrm{Mo} \mathrm{1}, \mathrm{Ba} 750$, La 92, Pb 20; average contents of Pacific clays, computed from the literature, Sc $25, \mathrm{Ti} 4,600, \mathrm{~V} 130, \mathrm{Cr} 78, \mathrm{Mn}$ 9,400, $\mathrm{Co} \mathrm{110,} \mathrm{Ni} \mathrm{300,} \mathrm{Cu} \mathrm{400,} \mathrm{Zn} \mathrm{200,} \mathrm{Ga} \mathrm{19,} \mathrm{Rb} \mathrm{110,} \mathrm{Sr} 200$ (carbonate free), Y $150, \mathrm{Zr} 160, \mathrm{Mo} 46, \mathrm{Ba} 4,000$, La 150, Pb 110 . JDV

00337 Wedepohl, K. H. Untersuchungen zur Geochemie des Zinks [Investigation of the geochemistry of zinc (in German; English abs.)]: Geochim. et Cosmochim. Acta, v. 3, p. 93-142, 1953.

A spectrochemical method for the determination of as little as $1 \mathrm{ppm} \mathrm{Zn}$ in rocks and minerals has been developed. By means of fractionated distillation, the 
separation of $\mathrm{Zn}$ in silicates and spinels from $\mathrm{Zn}$ in $\mathrm{ZnS}$-bearing rocks is possible. Results from 130 analyses confirm the figures given by Clarke and Washington (1924) (40 ppm Zn) and unpublished results by V. M. Goldschmidt (1938) (40 ppm) for the crustal abundance of $\mathrm{Zn}$. Average content of $\mathrm{Zn}$ in shales is also $40 \mathrm{ppm}$ which includes some of the following analyses $(\mathrm{Zn}$ in $\mathrm{ppm})$ : composite sample of 36 European Paleozoic shales 34, composite of 14 Japanese Paleozoic shales 39 , Composite of 10 Japanese Mesozoic shales 39, Culmtonschiefer 63, Lias $\alpha_{1}$ shale 30, Lias $\epsilon$ Posidonienschiefer 59, 180, 620.-Author's abs., modified.

Wedepohl, K. H. See Turekian, K. K.00354

00334 Welby, C. W. Occurrence of alkali metals in some Gulf of Mexico sediments: Jour. Sed. Petrology, v. 28, no. 4, p. 431-452, 1958.

The abundance of alkali metals in 130 samples from the Gulf of Mexico was determined spectrographically. $R b$ is only slightly enriched with respect to $K$, but $\mathrm{Cs}$ is significantly enriched with respect to both $\mathrm{K}$ and $\mathrm{Rb}$. $\mathrm{Li}$ abundance is similar to that in igneous rocks. Thermal analyses suggest that $\mathrm{Rb}$ is enriched with respect to $\mathrm{K}$ in illite-rich sediments and that these sediments are relatively low in Cs. A relatively high $\mathrm{Li}$ content is probably associated with montmorillonite-rich sediments. Alkali metal content apparently does not vary systematically with depth below the present sedimentary interface or with distance from shore. Much of the separation of alkali metals and enrichment of one with respect to another may occur during weathering. Hydrated radii and ionic potential based on hydrated radii are not the only factors controlling the behavior of alkali metals during weathering and sedimentary cycles. Average contents of alkali metals by environment are (in ppm): Atchafalaya Bay, 12 samples, $\mathrm{Rb}_{2} \mathrm{O} 260, \mathrm{Cs}_{2} \mathrm{O} 5.2, \mathrm{Li}_{2} \mathrm{O}$ 130; San Antonio Bay, 4 samples, $\mathrm{Rb}_{2} \mathrm{O} 250, \mathrm{Cs}_{2} \mathrm{O}$ 13, $\mathrm{Li}_{2} \mathrm{O} 170$; Rockport-offshore, 3 samples, $\mathrm{Rb}_{2} \mathrm{O}$ 260, $\mathrm{Cs}_{2} \mathrm{O}$ 5.4, $\mathrm{Li}_{2} \mathrm{O} 89$; Mississippi Delta, 14 samples, $\mathrm{Rb}_{2} \mathrm{O} 120, \mathrm{Cs}_{2} \mathrm{O} 3, \mathrm{Li}_{2} \mathrm{O}$ 81; globigerina oozes, 19 samples, $\mathrm{Rb}_{2} \mathrm{O} 260, \mathrm{Cs}_{2} \mathrm{O} 9.3, \mathrm{Li}_{2} \mathrm{O}$ 130; Gulf of Mexico, exclusive of oozes, 78 samples, $\mathrm{Rb}_{2} \mathrm{O} 360, \mathrm{Cs}_{2} \mathrm{O} 8.1, \mathrm{Li}_{2} \mathrm{O} \quad 140$; composite sample of Austin Chalk, Eagle Ford Shale, lower part, Eutaw Formation, Selma Chalk, Tuscaloosa Formation (all of Cretaceous age), Cherokee Shale (Pennsylvanian), and Miocene nodular chalk, $\mathrm{Rb}_{2} \mathrm{O} 170, \mathrm{Cs}_{2} \mathrm{O} 4.3, \mathrm{Li}_{2} \mathrm{O}$ 91.-Author's abs., modified.

00322 Wells, R. C. Relative abundance of nickel in the earth's crust: U.S. Geol. Survey Prof. Paper 205-A, 21 p., 1943.

More than 150 new determinations of $\mathrm{Ni}$ were made on samples of rocks previously analyzed in the chemical laboratory of the U.S. Geological Survey. Ni was determined in all common types of rock, including the more silicic as well as the highly ferromagnesian, but is decidedly more abundant in ferromagnesian rocks. $\mathrm{Ni}$ is present in most shales and in many silts and clays, including abyssal oceanic red clay. An accurate estimate of the crustal abundance of $\mathrm{Ni}$ under present limitations of knowledge is difficult, but $160 \mathrm{ppm}$ is considered a reasonable figure. The average of 12 new determinations of $\mathrm{NiO}$ in shale and clay is $89 \mathrm{ppm}$. This includes diatomaceous shale, deep-sea red clay, river silt, bentonite, Swedish kolm, red glacial till, clay residue from limestone, and siliceous shales; values range from 11 to 280 ppm.-Author's abs., modified.

00323 Wells, R. C.; Stevens, R. E. Further studies of kolm: Washington Acad. Sci. Jour., v. 21 , no. 17 , p. $409-414,1931$.

The principal object of the analytical work was to determine the age of kolm from $\mathrm{Pb}: \mathrm{U}$ ratio. The sample of kolm [composite?] was from the middle and lower parts of the Peltura beds of Late Cambrian age from near Skovde, Westergötland, Sweden. The material contained about 1.8 percent moisture, 29.5 percent volatile matter, 43.6 percent fixed $\mathrm{C}, 35.1$ percent ash, $30 \mathrm{ppm} \mathrm{V}_{2} \mathrm{O}_{5}, 400 \mathrm{ppm} \mathrm{ZnO}, 1,300 \mathrm{ppm}$ rare-earth elements, $130 \mathrm{ppm} \mathrm{Mo,} 30 \mathrm{ppm} \mathrm{MnO}$, and $40 \mathrm{ppm} \mathrm{NiO}$. Trace element contents were calculated back to kolm.-EBT

00330 Wells, R. C. Analyses of rocks and minerals from the laboratory of the United States Geological Survey, 1914-1936: U.S. Geol. Survey Bull. 878, 134 p., 1937. 
This bulletin supplements U.S. Geological Survey Bulletin 591 which contains analyses run during 1880-1914. Data on major-element contents in igneous and crystalline rocks, sandstones, cherts, sinters, carbonate rocks, slates, shales, ores, gangue materials, and minerals are reported. Some minor-element data on the kolm of Late Cambrian age in Sweden (see also Wells and Stevens, 1931) are included. Electroscopic determination showed 0.28 percent $\mathrm{UO}_{3}$ in the kolm.-EBT

Werner, H. See Ernst, Werner. 00129

00324 Westergard, A. H. Borrningar genom Skånes alunskiffer 1941-42 [Borings through the alum shales of Scania made in 1941-42 (in Swedish; English summ.)]: Sveriges Geol. Undersökning, Ser. C, N:o 459, Ärsb. 38, N:o 1, 45 p., 1944 a.

Besides $\mathrm{Fe}$, only $\mathrm{V}$ occurs in significant amounts in the cores of 5 boreholes; average $V$ content ranges from 0.20 percent at Andrarum to 0.28 percent at south Sanby in Dictyonema Shale, from 0.13 to 0.17 in the top of the Olenid Shale, and from 0.05 to 0.10 percent in the lower part, Olenid and the Paradoxides Shales. Spectral analyses show that $\mathrm{V}$ is concentrated in organic matter. In the alum shales, Mo content ranges from 100 to $200 \mathrm{ppm}$, Ni from 100 to 400 , and $\mathrm{Co}$ is about onetenth of $\mathrm{Ni}$ content. U content of the Olenid Shale at Sanby ranges from 100 to $300 \mathrm{ppm}$ and decreases downward from 50 to $25 \mathrm{ppm}$ in the lowest part of the Olenid Shale to $15 \mathrm{ppm}$ in the Paradoxides Shale. Ra content is approximately one third of a millionth of the $U$ content. Stratigraphy and paleontology of the cores are also discussed in detail._EBT

00325 Westergard, A. H. Borrningar genom Alunskifferlagret på Oland och i Ostergötland, 1943 [Borings through the alum shales of Oland and Ostergötland made in 1943 (in Swedish; English summ.)]: Sveriges Geol. Undersökning, Ser. C, N:o 463, Årsb. 38, N:o 5, 22 p., 1944 b.

On southern Oland 3 borings were made through the Cambrian alum shales and in Ostergötland, 2. The stratigraphy and paleontology are described and results of chemical and spectral analyses given. In Ostergötland the range of minor-element composition is (in ppm): Dictyonema Shale: Mo 110-160, Ni 100-240, Co 2050, Cu 60-200, U 115-190, V 600-2,700; Olenid Shale: Mo 140-160, Ni 70-160, Co 20-60, Cu 50-150, U 120-145, V 300-700; and Paradoxides Shale: V 200-600. In Oland the average composition is (in ppm): Ceratopyge Shale: Mo 80, Ni 120, V 1,200-2,500; Dictyonema Shale: Mo 140, Ni 210. V 1,700-3,100; Olenid Shale: Mo 120, Ni 90, V 300-1,300; average for section of alum shales: Co 30, U 4590.--EBT

White, W. A. See Ostrom, M. E. 00267

00326 White, W. A. Chemical and spectrochemical analyses of Illinois clay material: Illinois Geol. Survey Circ. 282, 55 p., 1959.

All published and unpublished chemical and spectrochemical analyses available for Illinois clay materials are brought together. Spectrochemical analyses for minor elements include the following samples: dark gray shale. Orchard Creek Shale, Silurian, B 90, Co 15, Cr 70, Cu 30, Ga 25, Mn 100, Ni 20, Pb 65, V 80, Zr 280; organic-rich shale, Waltersburg Sandstone, Mississippian, B 120, Co 15, Cr 90, Cu $60, \mathrm{Ga} 30, \mathrm{Mn} 160$, Ni 50, Pb 65, V 80, Zr 110; dark-gray shale, Purington Shale, Pennsylvanian, B 90, Co 20, Cr 85, Cu 80, Ga 30, Mn 640, Ni 40, Pb 60, V 140, $\mathrm{Zr}$ 180; composite sample, Tradewater Formation, Pennsylvanian, B 100, Co 20, $\mathrm{Cr} 110, \mathrm{Cu} 250, \mathrm{Ga} 35, \mathrm{Mn} 590, \mathrm{Ni} 60, \mathrm{~Pb} 70, \mathrm{~V} 125, \mathrm{Zr} 150$; organic-rich shale, Brereton Limestone, Pennsylvanian, B 130, Co 20, Cr 155, Cu 270, Ga 100, Mn $480, \mathrm{Ni} 90, \mathrm{~Pb} 55, \mathrm{~V} 135, \mathrm{Zr} 140 . \quad$ Estimated uncertainty is (in percent): $\mathrm{B} \pm 10$, $\mathrm{Co} \pm 20, \mathrm{Cr} \pm 30, \mathrm{Cu} \mathrm{X} / 2$ (near detection limit of $100 \mathrm{ppm}$ ), Ga $\pm 10, \mathrm{Mn} \pm 30$, $\mathrm{Ni} \pm 10, \mathrm{~Pb} \pm 30, \mathrm{~V} \pm 10$, and $\mathrm{Zr} \pm 20$. $-\mathrm{EBT}$

00331 White, W. H.; Northcote, K. E. Distribution of metals in a modern marine environment: Econ. Geology, v. 57, no. 3, p. 405-409, 1962.

Distribution of $\mathrm{Fe}, \mathrm{S}, \mathrm{Cu}, \mathrm{Pb}$, and $\mathrm{Zn}$ was studied in modern sediments in Mud Bay, an area of about $4 \mathrm{sq}$ mi of tidal flats, submerged at medium tide, at the 


\section{BIBLIOGRAPHY OF MINOR ELEMENTS IN BLACK SHALES}

mouths of Serpentine and Nicomekl Rivers, $15 \mathrm{mi}$ south of Vancouver, B. C. S content ranges from 0.33 to 2.11 percent; Fe content, from 1.54 to 3.87 percent. $\mathrm{Cu}$ content ranges from 5 to $122 \mathrm{ppm}$; amounts more than $20 \mathrm{ppm}$ are considered anomalous. The distribulion pattern of $\mathrm{Cu}$ is marked by a well-defined belt of high values fringing the high-water mark; that of $\mathrm{Zn}$ is roughly similar. $\mathrm{Zn}$ content ranges from 18 to $109 \mathrm{ppm}$; more than $40 \mathrm{ppm}$ is considered anomalous. $\mathrm{Pb}$ content of all samples is very low, generally 1 or $2 \mathrm{ppm}$. The metals accumulate preferentially in fine-grained sediments. Values for $\mathrm{Cu}$ and $\mathrm{Zn}$ are higher than the average basemetal content of Fraser Valley subsoil and the $\mathrm{Cu}: \mathrm{Zn}$ ratio is also higher. Both $\mathrm{Cu}$ and $\mathrm{Zn}$ are trapped in tidal sediment; $\mathrm{Cu}$ is more enriched there than $\mathrm{Zn}$.EBT

00320 White, W. S.; Wright, J. C. The White Pine copper deposit, Ontonagon County, Michigan: Econ. Geology, v. 49, no. 7, p. 675-716, 1954.

The Nonesuch Shale of late Keweenawan age is a gray siltstone about 600 feet thick. $\mathrm{Cu}$, mostly in chalcocite, is found in the lower 20-25 feet of the Nonesuch and in the upper few feet of the underlying Copper Harbor Conglomerate. This part of the section is divided into 4 local units-lower sandstone (uppermost bed of the Copper Harbor), parting shale, upper sandstone, and upper shale, all probably deltaic sediments. Most of the $\mathrm{Cu}$ is in the upper and parting shales; $\mathrm{Cu}$ content is higher where the beds are thicker. $\mathrm{Cu}$ decreases in shale with increasing. sand content. Distribution of $\mathrm{Cu}$ in the shales seems independent of local structure, faults, and rock permeability; control is lithologic and stratigraphic. $\mathrm{Cu}$ may have been precipitated within the original mud, or may have replaced something else so deposited. In a massive bed in the middle of the parting shale $\mathrm{Cu}$ content ranges from 0.27 to 2.28 percent; in the upper shale, from 0.07 to 1.11 percent.-Authors' abs., modified.

00321 White, W. S. The copper shales of Germany and Michigan [abs.]: Econ. Geology, v. 48, no. 7, p. 631, 1953.

The Precambrian Nonesuch Shale of northern Michigan and the Permian Kupferschiefer of Mansfeld, Germany, contain Cu sulfides finely dispersed over many square miles in black organic shale that overlies thick coarse red continental deposits, gray at the top. In a zone 1 to 2 feet above the sandstone, the shale contains about 3 percent $\mathrm{Cu}$, concentrated in shallow depressions in the top of the sandstone, probably within a few miles of the ancient shoreline. The Kupferschiefer contains bornite and subordinate amounts of chalcocite and chalcopyrite and $\mathrm{Pb}$ and $\mathrm{Zn}$; the $\mathrm{S}$-poor Nonesuch contains chalcocite, minor native $\mathrm{Cu}$, and traces of bornite or chalcopyrite. At White Pine, Mich., the sequence of sandstone and $\mathrm{Cu}$ shale is repeated cyclically; $\mathrm{Cu}$ per unit area is more than 5 times that at Mansfeld. $\mathrm{Cu}$ in these shales is believed syngenetic; in both formations $\mathrm{Cu}$ is closely related to sedimentary facies and only locally affected by structural features.-Author's abs., condensed.

00332 White, W. S. The White Pine copper deposit: Econ. Geology, v. 55, no. 2, p. $402-409,1960$.

Arguments for diagenetic deposition of the $\mathrm{Cu}$ deposits in the Nonesuch Shale of Precambrian age in northern Michigan are presented. The size of the area $(1,000$ square miles) suggests a widespread rather than a local agent of $\mathrm{Cu}$ distribution. The kind of regional movements of connate water that must take place when a large sedimentary prism is compacted would satisfy the implications of both the widespread distribution of $\mathrm{Cu}$ and the evidence that $\mathrm{Cu}$ was present before the copper-bearing carbonaceous beds were compacted or deformed. Most of the $\mathrm{Cu}$ probably arrived after the uppermost cupriferous beds were in place and perhaps covered by several tens or even hundreds of feet of overlying beds. Because both the permeability of the shales and the chemical activity of the organic matter would decrease rapidly with time and burial, the earlier the origin, the more readily it is explained.-EBT

00333 White, W. S.; Wright, J. C. Lithofacies of the Copper Harbor Conglomerate, northern Michigan, in Short papers in the geological sciences: U.S. Geol. Survey Prof. Paper 400-B, p. B5-B8, 1960. 
The Copper Harbor Conglomerate, chiefly arkosic conglomerate and sandstone, cemented with calcite and laumontite, of late Keweenawan age, crops out along the south limb of the Lake Superior syncline in northern Michigan and along its north limb on Isle Royale. It is underlain by a thick sequence of flood basalts and overlain by the Nonesuch Shale and Freda Sandstone. $\mathrm{Cu}$ in the base of the Nonesuch may have been deposited from connate water that was sequeezed out of the Keeweenawan sediments during compaction and diagenesis. The coarse-grained facies of the Copper Harbor may give way to fine-grained sediments in the central part of the basin, far downdip from the $\mathrm{Cu}$ deposits. The thick mass of rhyolite in the Copper Harbor may have acted like a buried hill to intensify the flow of water up into the Nonesuch; this mechanism could explain the unusual concentrations of $\mathrm{Cu}$ close to the rhyolite border.-EBT

00313 Whitney, P. R.; Hurley, P. M. The problems of inherited radiogenic strontium in sedimentary age determinations: Geochim. et Cosmochim. Acta, v. 28, p. 425$436,1964$.

Results of analyses for $\mathrm{Rb}$ and $\mathrm{Sr}$ in samples of the Marcellus Shale of Middle Devonian age in New York and Pennsylvania are reported. Rb content in blackshale samples ranges from 152.5 to $213.7 \mathrm{ppm}$; the $\mathrm{Sr}$ content, from 67.9 to 289.5 ppm.-EBT

Wickman, F. E. See Krejci-Graf, Karl. 00207

00314 Wildeman, T. R.; Haskin, Larry. Rare-earth elements in ocean sediments: Jour. Geophys. Research, v. 70, no. 12, p. 2905-2910, 1965.

Rare-earth element abundances, in ppm, for a composite sample of 40 North American shales and for 8 samples of ocean sediments from the Pacific and Atlantic Oceans are presented. Variation in absolute concentration among the samples did not exceed a factor of 3 for any rare earth. Average relative abundances of rare earths in ocean sediments was the same as that previously reported for limestones, sandstones, and shales. Rare-earth contents in the composite shale sample are (in ppm): Y 35.1, La 39.1, Ce 76.4, Pr 10.3, Nd 37.2, Sm 6.99, Eu 1.96, Gd 6.08, Tb 1.30, Dy --, Ho 1.40, Er 4.01, Tm 0.58, Yb 3.40, and Lu 0.60; and in the ocean sediments (averages; standard deviations in parentheses): Y $26.9( \pm 2.7)$, La 26.1 $( \pm 3.2)$, Ce 55.2 $( \pm 4.7), \operatorname{Pr} 7.34( \pm 1.1)$, Nd $30.0( \pm 3.9)$, Sm $5.59( \pm 0.84)$, Eu 1.60 $( \pm 0.17)$, Gd $6.33( \pm 1.0)$, Tb $1.04( \pm 0.14)$, Ho $1.03( \pm 0.11)$, Er $3.08( \pm 0.34)$, Tm $0.47( \pm 0.05)$, Yb $3.03( \pm 0.45)$ - - EBT

Williams, E. G. See Degens, E. T. 00048

Williams, E. G. See Degens, E. T. 00083

Williams, G. D. See Campbell, F. A. 00060

Williams, K. T. See Byers, H. G. 00063

00315 Williams, K. T.; Lakin, H. W.; Byers, H. G. Selenium occurrence in certain soils in the United States, with a discussion of related topics. Fifth report: U.S. Dept. Agriculture Tech. Bull. 758, 69 p., 1941.

Samples of Bearpaw Shale [of Cretaceous age] from the plains in western Canada contained less than $10 \mathrm{ppm}$ Se. One sample from Alberta, specifically listed as black shale, contained $0.3 \mathrm{ppm}$ Se.-EBT

Wilmarth, V. R. See Warner, L. A. 00339

Wilson, S. R. See King, W. H. 00213

Winchester, J. W. See Coryell, C. D. 00067

Witte, H. See Goldschmidt, V. M. 00086 
Witters, J. See Potter, P. E. 00261

Wollin, Goesta. See Ericson, D. B. 00044

Wright, J. C. See White, W. S. 00320

Wright, J. C. See White, W. S. 00333

00316 Wright, T. L.; Fleischer, Michael. Geochemistry of the platinum metals: U.S. Geol.Survey Bull. 1214-A, p. A1-A24, 1965.

The literature pertaining to the geochemistry of platinum metals is summarized. The platinum metals- Pt, Ir, Os, Pd, Rh, and $\mathrm{Ru}-$ occur as alloys of metals, as intermetallic compounds, as compounds with $\mathrm{O}, \mathrm{S}, \mathrm{Te}, \mathrm{As}, \mathrm{Sb}, \mathrm{Sn}$, and $\mathrm{Bi}$, and in trace amounts (as much as $10 \mathrm{ppm}$, although commonly less than $1 \mathrm{ppm}$ ) in rock-forming minerals. Abundances in igneous rocks, estimated to within an order of magnitude, are (in ppm): ultramafic 0.05 , mafic 0.02 , and silicic and intermediate 0.005 . Data are insufficient to estimate for metamorphic and common sedimentary rocks. Some uncommon sediments-for example, copper-bearing shale, coal ashhave contents as much as $1 \mathrm{ppm}$. Recent estimates of crustal abundances are (in $\mathrm{ppm}$ ): $\mathrm{Pd} 0.01-0.02, \mathrm{Pt} 0.005, \mathrm{Ir}, \mathrm{Os}, \mathrm{Rh}$, and $\mathrm{Ru}$ all $<0.001$; the relative abundances are: $P d>P t>I r \geq O s \geq R h \approx R u$. In black shale the ranges found (in $p p m$ ) are: Pt 0.01-0.05, Ir --, Os -.., Pd 0.05, Rh 0.01-0.02, Ru 0.04-0.08; in the Mansfeld Kupferschiefer: Pt 0.05, Ir 0.004, Os 0.003, Pd 0.02, Rh 0.0002, and Ru 0.003.Authors' abs., modified.

00317 Young, E. J. Trace elements in Recent marine sediments [abs.]: Geol. Soc. America Bull., v. 65 , no. 12 , pt. 2, p. $1329,1954$.

Trace-element distribution in 96 samples of Recent marine sediments and some older sediments was studied spectrographically using $\mathrm{PdCl}_{2}$ as an internal standard. Ba and $\mathrm{Sr}$ were analyzed semiquantitatively, the other elements quantitatively. Precision-expressed as standard deviation-ranged from 5 percent for $\mathrm{Co}_{2} \mathrm{O}_{3}$ to 14 percent for $\mathrm{ZrO}_{2}$. Red clay contained the following (average of 20 samples in ppm): $\mathrm{ZrO}_{2} 230, \mathrm{TiO}_{2} 7,000, \mathrm{~V}_{2} \mathrm{O}_{5} 260, \mathrm{Cr}_{2} \mathrm{O}_{3} 120$, NiO 330, $\mathrm{Co}_{2} \mathrm{O}_{3} 138, \mathrm{Sc}_{2} \mathrm{O}_{3}$ 48, $\mathrm{La}_{2} \mathrm{O}_{3} 260$, SrO 700, $\mathrm{BaO} 9,000$; nearshore sediments contained (average of 20 samples): $\mathrm{ZrO}_{2} 300, \mathrm{TiO}_{2} 6,700, \mathrm{~V}_{2} \mathrm{O}_{5} 230, \mathrm{Cr}_{2} \mathrm{O}_{3} 120, \mathrm{NiO} 60, \mathrm{Co}_{2} \mathrm{O}_{3} 16, \mathrm{Sc}_{2} \mathrm{O}_{3}$ $21, \mathrm{La}_{2} \mathrm{O}_{3} 110$, SrO $350, \mathrm{BaO} 1,700$. The similar amounts of $\mathrm{Zr}, \mathrm{Ti}, \mathrm{V}$, and $\mathrm{Cr}$ in oceanic clay, nearshore sediments, and the average igneous rock indicate a terrigenous origin for red clay.--Author's abs., condensed.

Young, W. A. See Allsman, P. T. 00020

Young, W. A. See Allsman, P. T. 00021

Zalmanzon, E.S. See Strakhov, H. M. 00291

00318 Zangerl, Rainer; Richardson, E. S., Jr. The paleoecological history of two Pennsylvanian black shales: Chicago Nat. History Mus., Fieldiana, Geology Mem., v. 4,372 p., 1963.

The physical, chemical, and biological forces that formed the deposits of black carbonaceous shale containing unusually large concentrations of vertebrate skeletons overlying the Logan Quarry coal and Coal IIIA (Indiana nomenclature) of Middle Pennsylvanian age are analyzed. Two small quarries were excavated and nearby outcrops studied in Parke County, Ind. The Mecca Quarry Shale Member of Linton Formation and Logan Quarry Shale Member of Staunton Formation record the initial stages of marine transgression over a slightly uneven coastal plain. Concentrations of fossils were the result of crowding of animals into residual ponds during dry seasons; water near the top remained inhabitable, but the bottoms of the ponds were quiet and extremely toxic. Ashes of a suite of samples from the Mecca Quarry Shale Member were analyzed spectrographically for minor elements. Quantities are expressed as though the elements were present as oxides; $\mathrm{Ag}, \mathrm{Zn}$, $\mathrm{Cd}, \mathrm{Sb}$, and $\mathrm{Pb}$ are probably present as sulfides. Ranges of content in ash of 7 samples of gray to black shale are (in ppm; $100>\mathrm{X}>50,+=\sim 100$ ): $\mathrm{MnO} 270$ $440, \mathrm{MoO}_{3} 1,200-7,000, \mathrm{Cr}_{2} \mathrm{O}_{3}$ 1,500-2,400, NiO 800-2,600, CuO 450-1,300, $\mathrm{V}_{2} \mathrm{O}_{5}$ 6,000-11,000, $\mathrm{CoO} 20-150, \mathrm{ZrO}_{2} 200-290, \mathrm{Y}_{2} \mathrm{O}_{3} 10-70, \mathrm{Yb}_{2} \mathrm{O}_{3}$ 6-13, $\mathrm{Sc}_{2} \mathrm{O}_{3} 30-35$, 
$\mathrm{La}_{2} \mathrm{O}_{3} 50-120, \mathrm{BaO} 200-500$, SrO 180-300, SnO 3-100, PbO 90-450, $\mathrm{TiO}_{2} 15-110$, $\mathrm{Sb}_{2} \mathrm{O}_{3} \mathrm{X}-220, \mathrm{CdO} \mathrm{X}-+, \mathrm{Ag}_{2} \mathrm{O} 10-30, \mathrm{ZnO} 100-1,000, \mathrm{Ga}_{2} \mathrm{O}_{3} 25-35 ; 1$ sample of black marine shale: $\mathrm{MnO} \mathrm{tr}, \mathrm{MoO}_{3} 350, \mathrm{Cr}_{2} \mathrm{O}_{3} 450, \mathrm{NiO} 450, \mathrm{CuO} \mathrm{tr}, \mathrm{V}_{2} \mathrm{O}_{5} 1,000$, $\mathrm{CoO} 10, \mathrm{ZrO}_{2} 210, \mathrm{Y}_{2} \mathrm{O}_{3} 50, \mathrm{Yb}_{2} \mathrm{O}_{3} 5, \mathrm{Sc}_{2} \mathrm{O}_{3} 22, \mathrm{La}_{2} \mathrm{O}_{3} 77, \mathrm{BaO} 600, \mathrm{SrO} 200$, $\mathrm{SnO} 10, \mathrm{PbO} 50, \mathrm{Ti}_{2} \mathrm{O} 20, \mathrm{Sb}_{2} \mathrm{O}_{3} \mathrm{X}, \mathrm{CdO} \mathrm{X}, \mathrm{Ag}_{2} \mathrm{O} 10, \mathrm{ZnO} 300, \mathrm{Ga}_{2} \mathrm{O}_{3}$ 30.-EBT

Zimmerman, D. O. See Love, L. G. 00164

Zul'fugarly, D. I. See Seidov, A. G. 00305

00319 Zul'fugarly, N. D.; Geydarov, A. S.; Nuriyev, A. N. Radioelementy v glinistykh porodakh sarmatskikh otlozheniy [Radioelements in clayey rocks of Samatian deposits]: Azerbaidzhan Khim. Zhur. 1962, no. 2, p. 119-122, 1962 [As seen in translation by Michael Fleischer, 1963, written commun.]

Th was determined colorimetrically, $U$ by luminescence and $R \mathbf{a}$ by radiochemical methods, in 12 samples of clayey rocks from Sarmatian deposits of oldest late Miocene age in the Nakhichevan Autonomous SSR. U content ranged from 0.7 to $5.91 \mathrm{ppm}$, Th from 0.83 to $2.53 \mathrm{ppm}, \mathrm{Ra}$ from $0.76 \times 10^{-6}$ to $2.5 \times 10^{-6} \mathrm{ppm}$, and total organic matter from 1.81 to 3.24 percent.-EBT 
7 


\section{INDEX}

[The numbers refer to entries in the abstracts]

\section{Adriatic Sea}

Ocean sediment

Chromium, cobalt, molybdenum, nickel,

Africa

vanadium: Seibold, Eugen. 00304

\section{Ocean sediment}

Gold, silver: Goldschmidt, V. M. 00116

Alabama

Precambrian

Titanium, vanadium: Pallister, H. D. 00263

Alaska

Geochemical abundance

Molybdenum: Kuroda, P. K. 00200

Mississippian

Uranium, vanadium: Mayzko, J. J. 00157

Permian and Triassic

Albania

Minor elements: Ugolini, F. C. 00346

Mesozoic

Minor elements: Katchenkov, S. M. 00193

Tertiary

Minor elements: Katchenkov, S. M. 00193

Alberta

Cretaceous

Rubidium, strontium: Campbell, F. A. 00060 Devonian

Rubidium, strontium: Campbell, F. A. 00060

Alkali metals

Geochemical abundance

Gulf of Mexico: Welby, C. W. 00334

Paleozoic

Europe: Goldschmidt, V. M.00117

Alum shale

Element abundance

Boron: Landergren, Sture. 00178

Chromium, cobalt, nickel, zinc: Lundegårdh, P. H. 00160

Cobalt, copper, nickel, molybdenum, uranium, vanadium: Westergard, A. H. 00325

Cobalt, molybdenum, nickel, uranium, vanadium: Westergard, A. H. 00324

Gold, silver: Leutwein, Friedrich. 00139

Lead, uranium: Cobb, J. C. 00054

Manganese, molybdenum, uranium: Strahl, E. O. 00290

Minor elements: Bain, G. W. 00008

Minor elements: Landergren, Sture. 00175

Minor elements: Schneiderhöhn, H. 00235

Minor elements: Vesterberg, K. Alb. 00409

Molybdenum, tungsten, vanadium:

Assarsson, G. O. 00005

Radium, uranium: Strutt, R. J. 00294

Radium, uranium, zinc: Landin, John. 0017

Tantalum: Rankama, Kalervo. 00253

Thorium, uranium: Koczy, F. F. 00406

Uranium: Davidson, C. F. 00078

Uranium: Larsson, Alf. 00174

Uranium: Skjeseth, Steinar. 00303

Uranium: Wells, R.C. 00330

Vanadium: Assarsson, G. 00006

Zinc: Lundegårdh, P. H. 00162

Geochemical distribution

Uranium: Rynninger, Roland. 00228

\section{A lum shale}

Source of the elements

Thuringia: Leutwein, Friedrich. 00138

\section{Antimony}

Geochemical abundance

Sedimentary rocks: Onishi, Hiroshi. 00269

Appalachian coal basin

Carboniferous

Minor elements: Degens, E. T. 00083

Pennsylvanian

Minor elements: Keith, M. L. 00194

\section{Arkansas}

Devonian, Mississippian

Semiquantitative spectrographic analyses, uranium: Landis, E. R. 00173

Semiquantitative spectrographic analyses, uranium: Swanson, V. E. 00277

Ordovician

Molybdenum: Kuroda, P. K. 00200

Arsenic

Cretaceous

South Dakota: Moxon, A. L. 00239

Geochemical abundance

Sedimentary rocks: Onishi, Hiroshi. 00268

Sedimentary rocks: Onishi, Hiroshi. 00269

Oil shale

Scotland: Cadman, W. H. 00072

Permian

Silesia: Harańczyk, C. 00096

Thuringia: Rösler, H. J. 00225

Asia, central

Tertiary

Selenium: Chentsov, I. G. 00073

Atlantic Ocean

Geochemical distribution

Minor elements: Landergren, Sture. 00175

Ocean sedimeni

Barium: Turekian, K. K. 00352

Chromium, copper, lead, nickel, strontium: Turekian, K. K. 00350

Gold, iridium: Baedecker, P. A. 00007

Minor elements: Ericson, D. B. 00044

Minor elements: Wakeel, S. K. El. 00342

Minor elements: Wedepohl, K.H.00336

Rare-earth elements: Wildeman, T. R. 00314

Selenium: Edgington, Glen. 00047

Australia

Geochemical abundance

Osmium, rhenium: Lovering, J. F. 00165

Precambrian

Copper, lead, silver, zinc: Stanton, R. L. 00295

Geochemical origin of sulfides: Love, L. G. 00164

Austria

Geochemical abundance

Minor elements: Brandenstein, M. 00038

Triassic

Uranium: Hecht, Friedrich. 00103

Azerbaidzhan

Cretaceous

Copper: Itkina, E. S. 00220

Tertiary

Copper: Itkina, E. S. 00220

Manganese, vanadium: Seidov, A. G. 00305 


\section{BIBLIOGRAPHY OF MINOR ELEMENTS IN BLACK SHALES}

\section{Azerbaidzhan}

Tertiary

Radium, thorium, uranium: Zul'fugarly, N. D. 00319

\section{Baltic Sea}

Geochemical distribution

Copper, lead, silver, uranium, zinc: Manheim, F. T. 00161

Minor elements: Manheim, F. T. 00159

Uranium: Swanson, V. E. 00289

Ocean sediment

Gold: Leutwein, Friedrich. 00139

Minor elements: Landergren, Sture. 00175

\section{Barium}

Carboniferous

Russian SFSR: Tikhomirova, E. S. 00288

Geochemical abundance

Mediterranean Sea: Joensuu, Oiva. 00185

Ocean sediment: Ericson, D. B. 00044

Ocean sediment: Young, E. J. 00317

Sedimentary rocks: Clarke, F. W. 00074

Geochemical distribution

Atlantic Ocean: Turekian, K. K. 00352

Mesozoic

Japan: Engelhardt, Wolf. 00044

Paleozoic

Europe, Japan: Engelhardt, Wolf. 00044

Russian platform: Katchenkov, S. M. 00188

Pennsylvanian

Illinois, Indiana: Murray, H. H. 00402

Permian

Idaho: Lotspeich, F. B. 00143

\section{Beryllium}

Carboniferous

Russian SFSR: Tikhomirova, E. S. 00288

Devonian

Tennessee, Texas: Warner, L. A. 00339

Eocene

United States: Warner, L. A. 00339

Geochemical abundance

Pacific Ocean: Merrill, J. R. 00148

United States: Warner, L. A. 00339

Ordovician

Norway: Goldschmidt, V. M. 00119

Paleozoic

Europe: Goldschmidt, V. M. 00119

\section{Biogeochemistry}

Organic solubilization

Minor elements: Evans, W. D. 00130

Precambrian

Michigan: Barghoorn, E. S. 00010

Minnesota: Cloud, P. E., Jr. 00075

Source of the elements

Minor elements: Blumer, Max. 00016

Syngenetic ore: Love, L. G. 00145

Syngenetic ore: Temple, K. L. 00286

\section{Bituminous rocks}

Element abundance

Boron, molybdenum, nickel, vanadium: Couderc, J. M. 00076

Chromium, copper, manganese, molybdenum, nickel, vanadium: Leutwein, Friedrich. 00169

Chromium, vanadium: Falke, Horst. 00126

Cobalt, chromium, molybdenum, nickel, tin, vanadium: Goldschmidt, V. M. 00086

Minor elements: Katchenkov, S. M. 00193

Minor elements: Schneiderhöhn, H.00235

Minor elements: Schröder, A. 00236

\section{Bituminous rocks}

Element abundance

Vanadium: Jost, Konrad. 00187

Source of the elements

Minor elements: Blumer, Max. 00016

Black Sea

Geochemical abundance

Rare-earth elements: Ostroyumov, E. A. 00244

Ocean sediment

Chromium, cobalt, copper, manganese, nickel, vanadium: Glagoleva, M. A. 00135

Cobalt, copper, chromium, manganese, nickel, strontium, vanadium: Glagoleva, M. A. 00121

Uranium: Kochenov, A. V. 00405

Vanadium: Ostroyumov, E. A. 00246

Boron

Carboniferous

England: Curtis, C. D. 00077

Europe: Porrenga, D. H. 00260

Europe, western: Ernst, Werner. 00128

Germany: Ernst, Werner. 00129

Great Britain: Spears, D. A. 00300

Geochemical abundance

Ocean sediment: Ericson, D. B. 00044

Ocean sediment: Goldschmidt, V. M. 00112

Ocean sediment: Harder, Hermann. 00099

Ocean sediment: Vinogradov, A. P. 00345

Geochemical distribution

Ocean sediment: Landergren, Sture. 00177

Sedimentary rocks: Harder, Hermann. 00100

Sedimentary rocks: Harder, Hermann. 00101

Sweden: Landergren, Sture. 00178

Geochemical indicator

Sedimentary rocks: Curtis, C. D. 00077

Sedimentary rocks: Degens, E. T. 00048

Sedimentary rocks: Goldschmidt, V. M. 00112

Sedimentary rocks: Landergren, Sture. 00177

Sedimentary rocks: Potter, P. E. 00261

Jurassic

Germany: Couderc, J. M. 00076

Mississippian

Nevada: Moore, D. M. 00149

Paleozoic

Europe: Goldschmidt, V. M. 00087

Europe: Harder, Hermann. 00099

Norway: Goldschmidt, V. M. 00087

Tertiary

Germany: Ernst, Werner. 00131

British Columbia

Fjord sediment

Minor elements: Grant, G. M. 00089

Ocean sediment

Copper, lead, zinc: White, W..H. 00331

Triassic

Copper, manganese, titanium, vanadium:

Gunning, H.C. 00095

Vanadium: Jambor, J. L. 00218

\section{Bromine}

Carboniferous

Russian SFSR, southern: Itkina, E. S. 00222 


\section{Bromine}

Geochemical indicator

Sedimentary rocks: Gulyayeva, L. A. 00106

Mesozoic

Europe: Behne, Walter. 00028

Paleozoic

Europe: Behne, Walter. 00028

Russian SFSR, southern: Itkina, E. S. 00223

\section{Cadmium}

Cretaceous

United States, western: Tourtelot, H. A. 00282

Ocean sediment

Irish Sea: Mullin, J. B. 00152

Permian

Wyoming: Love, J. D. 00144

California

Cretaceous

Selenium: Lakin, H. W. 00179

Tertiary

Radioactive elements: Breger, I. A. 00035

Canada, western

Cretaceous

Selenium: Byers, H. G. 00062

Selenium: Williams, K. T. 00315

\section{Carpathian Mountains}

Tertiary

Uranium: Kita-Bada 1, M. 00214

Cesium

Geochemical abundance

Sedimentary rocks: Canney, F. C. 00064

Sedimentary rocks: Horstman, E. L. 00224

Silurian

Great Britain: Nicholls, G. D. 00273

Chlorine

Devonian

Russian SFSR, southern: Gulyayeva, L. A. 00106

Geochemical abundance

Germany, Japan: Correns, C. W. 00057

Mesozoic

Europe: Behne, Walter. 00028

Paleozoic

Europe: Behne, Walter. 00028

Chromium

Cambrian

Siberia, southern: Pushkina, Z. V. 00259

Carboniferous

Russian SFSR: Tikhomirova, E. S. 00288

Cretaceous

Uzbekistan: Amirkhanov, Sh. Kh. 00022

Uzbekistan: Amirkhanov, Sh. Kh. 00023

\section{Devonian}

Russian platform: Strakhov, H. M. 00291

Geochemical abundance

Adriatic Sea: Seibold, Eugen. 00304

Germany: Schneiderhöhn, H. 00235

Ocean sediment: Ericson, D. B. 00044

Ocean sediment: Young, E. J. 00317

Rumania: Goldschmidt, V. M. 00086

Sedimentary rocks: Leutwein, Friedrich. 00169

Sweden: Lundegảrdh, P. H. 00160

Union of Soviet Socialist Republics:

Tikhomirova, E. S. 00284
Chromium

Geochemical distribution

Black Sea: Glagoleva, M. A. 00121

Black Sea: Glagoleva, M. A. 00135

Ocean sediment: Landergren, Sture. 00177

Ocean sediment: Turekian, K. K. 00350

Geochemical indicator

Sedimentary rocks: Potter, P. E. 00261

Jurassic

Germany: Schröder, A. 00236

Saxony: Krejci-Graf, Karl. 00207

Mesozoic

Europe: Fröhlich, F. 00134

Paleozoic

Europe: Fröhlich, F. 00134

Russian platform: Katchenkov, S. M. 00188

Paleozoic, lower

Sweden: Lundegàrdh, P. H. 00167

Sweden: Vesterberg, K. Alb. 00409

Pennsylvanian

Illinois, Indiana: Murray, H. H. 00402

Permian

Europe: Deans, T. 00051

France: Falke, Horst. 00126

Idaho: Lotspeich, F. B. 00143

Silesia: Harańczyk, C. 00096

Wyoming: Love, J. D. 00144

Precambrian

Finland: Marmo, Vladi. 00146

Silurian

Thuringia: Leutwein, Friedrich. 00138

Tertiary

Clay

Poland: Głogoczowski, J. J. 00136

\section{Element abundance}

Germanium: Wardani, S. A. El. 00338

Minor elements: Katchenkov, S. M. 00181

Minor elements: Katchenkov, S. M. 00190

Cobalt

Cambrian

Siberia, southern: Pushkina, Z. V. 00259

Sweden: Westergard, A. H. 00324

Sweden: Westergard, A. H. 00325

Carboniferous

Russian SFSR: Tikhomirova, E. S. 00288

Devonian

Russian platform: Strakhov, H. M. 00291

Geochemical abundance

Adriatic Sea: Seibold, Eugen. 00304

Ocean sediment: Young, E. J. 00317

Rumania: Goldschmidt, V. M. 00086

Russian platform: Vinogradov, A. P. 00327

Sedimentary rocks: Carr, M. H. 00065

Sweden: Lundegårdh, P. H. 00160

Union of Soviet Socialist Republics:

Tikhomirova, E.S. 00284

Geochemical distribution

Black Sea: Glagoleva, M. A. 00121

Black Sea: Glagoleva, M. A. 00135

Ocean sediment: Landergren, Sture. 00177

Russian platform: Ronov, A. B. 00252

Geochemical indicator

Sedimentary rocks: Potter, P. E. 00261

Jurassic

England: Le Riche, H. H. 00137 
Cobalt

Jurassic

Germany: Sch röder, A. 00236

Saxony: Krejci-Graf, Karl. 00207

Mississippian

Nevada: Moore, D. M. 00149

Paleozoic, lower

Sweden: Lundegårdh, P. H. 00167

Sweden: Vesterberg, K. Alb. 00409

\section{Permian}

Europe: Deans, T. 00051

Silesia: Harańczy I, C. 00096

Precambrian

Finland: Marmo, Vladi. 00146

Triassic

Rumania: Savul, Mircea. 00234

Colorado

Cretaceous

Minor elements: Landis, E. R. 00172

Selenium: Byers, H. G. 00063

Uranium: Landis, E. R. 00172

Tertiary

Nickel, vanadium: Erdman, J. G. 00045

Vanadium: Thorne, H. M. 00287

\section{Columbia}

Geochemical abundance

Selenium: Ancizar-Sordo, Jorge. 00003

\section{Composite sample}

Element abundance

Alkali metals: Goldschmidt, V. M. 00117

Antimony, arsenic: Onishi, Hiroshi. 00269

Antimony, bismuth, cadmium, germanium, indium, mercury, thallium: Preuss, E. 00257

Arsenic, molybdenum: Onishi, Hiroshi. 00268

Barium: Engelhardt, Wolf. 00044

Beryllium: Goldschmidt, V. M. 00119

Boron: Goldschmidt, V. M. 00087

Boron: Harder, Hermann. 00099

Chromium: Fröhlich, F. 00134

Copper, zinc: Sugawara, Ken. 00276

Germanium: Goldschmidt, V. M. 00088

Germanium: Onishi, Hiroshi. 00241

Lead: Wedepohl, K. H. 00328

Lithium: Strock, L. W. 00292

Mercury: Stock, Alfred. 00298

Molybdenum: Kuroda, P. K. 00200

Rare-earth elements: Minami, E. 00180

Rare-earth elements: Wildeman, T. R. 00314

Selenium: Minami, E. 00155

Tin: Onishi, Hiroshi. 00242

Zinc: Wedepohl, K. H. 00337

Paleozoic

Europe: Noll, W. 00270

\section{Copper}

\section{Cambrian}

Siberia, southern: Pushkina, Z. V. 00259

Sweden: Westergard, A. H. 00325

Carboniferous

Russian SFSR: Tikhomirova, E. S. 00288

Russian SFSR, southern: Itkina, E. S. 00221

Cretaceous

Azerbaidzhan: Itkina, E. S. 00220

Uzbekistan: Amirkhanov, Sh. Kh. 00022

Devonian

New Mexico: Barnes, H. L. 00026

Russian platform: Strakhov, H. M. 00291
Copper

Devonian

Union of Soviet Socialist Republics: Katchenkov, S. M. 00189

Geochemical abundance

Ocean sediment: Ericson, D. B. 00044

Russian platform: Vinogradov, A. P. 00327

Sedimentary rocks: Leutwein, Friedrich. 00169

Sedimentary rocks: Sugawara, Ken. 00276

Union of Soviet Socialist Republics: Tikhomirova, E. S. 00284

Geochemical distribution

Black Sea: Glagoleva, M. A. 00121

Black Sea: Glagoleva, M. A. 00135

Ocean sediment: Turekian, K. K. 00350

Ocean sediment: White, W. H. 00331

Russian platform: Ronov, A. B. 00252

Geochemical indicator

Sedimentary rocks: Potter, P. E. 00261

Jurassic

England: Le Riche, H. H. 00137

Germany: Schröder, A. 00236

Switzerland: Bitterli, P. 00030

Mesozoic?

Mexico: Barnes, H. L. 00026

Mississippian

Nevada: Moore, D. M.00149

Ocean sediment

British Columbia: White, W. H. 00331

Ordovician

Wisconsin: Barnes, H. L. 00026

Paleogene

Rumania: Savul, Mircea. 00233

Paleozoic

Europe: Goldschmidt, V. M.00116

Russian platform: Katchenkov, S. M. 00188

Union of Soviet Socialist Republics: Gulyayeva, L. A. 00094

Paleozoic, lower

Sweden: Vesterberg, K. Alb. 00409

Permian

Europe: Deans, T. 00051

Europe: Richter-Bernburg, Gerhard. 00251

Germany: Kautzsch, Eberhard. 00217

Germany: Schuller, Arno. 00237

Germany: Steinbrecher, Bodo. 00297

Germany: White, W. S. 00321

Idaho: Lotspeich, F. B. 00143

New Mexico: Gott, G. B. 00111

Silesia: Eisentraut, Otto. 00042

Silesia: Harańczyk, C. 00096

Silesia: Harańczyk, C. 00097

Silesia: Konstantynowicz, E. 00198

Wyoming: Allsman, P. T. 00020

Permian and Triassic

Morocco: Lombard, J. 00168

Precambrian

Australia: Stanton, R. L. 00295

Finland: Marmo, Vladi. 00146

Michigan: Barghoorn, E. S. 00010

Michigan: White, W.S. 00320

Michigan: White, W. S. 00321

Michigan: White, W. S. 00332

Michigan: White, W. S. 00333 


\section{Copper}

Tertiary

Azerbaidzhan : Itkina, E. S. 00220

Triassic

British Columbia: Gunning, H. C. 00095

\section{Czechoslovakia}

Ordovician

Nickel, titanium, vanadium: Koblic, Josef. 00198

\section{Precambrian}

Spectrographic analyses: Flek, Jindrich. 00122

Silurian

Vanadium: Eckschlagerová, Marcela. 00046 Tertiary

Vanadium: Eckschlagerová, Marcela. 00046

\section{Denmark}

Geochemical distribution

Vanadium: Bøgvad, Richard. 00018

Earth's crust

Element abundance

All elements: Green, Jack. 00090

All elements: Green, Jack. 00109

Barium, lithium, manganese, titanium: Clarke, F. W. 00058

Barium, lithium, manganese, titanium: Clarke, F. W. 00074

Copper, zinc: Sugawara, Ken. 00276

Germanium: Wardani, S. A. El. 00344

Minor elements: Turekian, K. K. 00354

Minor elements: Vinogradov, A. P. 00349

Nickel: Wells, R. C. 00322

\section{Egypt}

Cretaceous

Semiquantitative spectrographic analyses:

Mustafa, Ahmed. 00272

Uranium: Higazy, R. A. 00104

\section{England}

Carboniferous

Boron: Curtis, C. D. 00077

Boron: Spears, D. A. 00300

Manganese, strontium: Greensmith, J. T. 00091

Thorium, uranium: Spears, D. A. 00299

Geochemical abundance

Gallium, germanium: Burton, J. D. 00070

Geochemical origin

Syngenetic ore: Love, L. G. 00145

Jurassic

Cobalt, copper, molybdenum, nickel, vanadium: Le Riche, H. H. 00137

Germanium: Hallam, A. 00105

Minor elements: Dunham, Kingsley. 00041 Syngenetic ore: Dunham, K. C. 00040

Paleozoic

Syngenetic ore: Dunham, K. C. 00040

Permian

Cobalt, copper, lead, molybdenum, nickel,

rubidium, strontium, zirconium, zinc: Hirst, D. M. 00085

\section{Enrichment factors}

Minor elements

Sedimentary rocks: Krauskopf, K. B. 00210

\section{Europe}

Carboniferous

Boron: Ernst, Werner. 00128
Europe

Carboniferous

Boron: Porrenga, D. H. 00260

Geochemical abundance

Bromine, chlorine: Behne, W alter. 00028

Geochemical distribution

Semiquantitative spectrographic analyses: Borchert, Herman. 00031

\section{Holocene}

Vanadium: Jost, Konrad. 00187

Jurassic

Lead: Wedepohl, K. H. 00328

Vanadium: Jost, Konrad. 00187

Zinc: Wedepohl, K. H. 00337

Zirconium: Degenhardt, Heinz. 00082

Paleozoic

Alkali metals: Goldschmidt, V. M. 00117

Antimony: Onishi, Hiroshi. 00269

Arsenic: Onishi, Hiroshi. 00268

Barium: Engelhardt, Wolf. 00044

Beryllium: Goldschmidt, V. M. 00119

Boron: Goldschmidt, V. M. 00087

Boron: Harder, Hermann. 00099

Copper: Goldschmidt, V. M. 00116

Copper, zinc: Sugawara, Ken. 00276

Germanium: Goldschmidt, V. M. 00088

Germanium: Onishi, Hiroshi. 00241

Lead: Wedepohl, K. H. 00328

Lithium: Strock, L. W. 00292

Mercury: Stock, Alfred. 00298

Minor elements: Preuss, E. 00257

Molybdenum: Kuroda, P. K. 00200

Rare-earth elements: Minami, E. 00180

Selenium: Minami, E. 00155

Strontium: Noll, W. 00270

Tantalum: Rankama, Kalervo. 00253

Zinc: Wedepohl, K. H. 00337

Zirconium: Degenhardt, Heinz. 00082

Paleozoic, Mesozoic

Chromium: Fröhlich, F. 00134

Permian

Chromium, cobalt, copper, lead, molybdenum, nickel, vanadium, zinc: Deans, T. 00051

Copper, lead, zinc: Richter-Bernburg, Gerhard. 00251

Geochemical origin: Love, L. G. 00163

Syngenetic ore: Wedepohl, K. H. 00335

Finland

Vanadium: Jost, Konrad. 00187

Precambrian

Cobalt, copper, chromium, molybdenum, nickel, vanadium, zinc: Marmo, Vladi. 00146

Minor elements: Peltola, Esko. 00264

Minor elements: Sahama, Th. G. 00229

Fjord sediment

Element abundance

British Columbia: Grant, G. M. 00089

Minor elements: Landergren, Sture. 00175

Uranium: Strøm, K. M.00293

Uranium: Swanson, V. E. 00289

\section{Fluorine}

Devonian

Germany: Koritnig, Sigmund. 00204 
Fluorine

Geochemical abundance

Germany, Japan: Correns, C. W. 00057

Jurassic

Germany: Koritnig, Sigmund. 00199

Germany: Koritnig, Sigmund. 00204

Ordovician

Germany: Koritnig, Sigmund. 00204

Permian

Germany: Koritnig, Sigmund. 00204

Fore-Caucasus

Tertiary

Minor elements: Pryakhina, YU. A. 00257

Minor elements: Pryakhina, YU. A. 00258

Uranium: Serikov, YU.1.00306

France

Carboniferous

Manganese, molybdenum, uranium: Strahl, E. O. 00290

Uranium: Bates, T. F. 00027

Uranium, spectrographic analyses: Grimbert, A rnold. 00092

Uranium, spectrographic analyses: Grimbert, Arnold. 00107

Jurassic

Minor elements: Maurel, P. 00147

Permian

Chromium, vanadium: Falke, Horst. 00126

Gallium

Carboniferous

Russian SFSR: Tikhomirova, E. S. 00288

Geochemical abundance

England: Burton, J. D. 00070

Mongolia: Vorob'ev, G. G. 00341

Shale: Bell, C. K. 00029

Geochemical indicator

Sedimentary rocks: Borisenko, L. A. 00033

Sedimentary rocks: Degens, E. T. 00048

Sedimentary rocks: Potter, P. E. 00261

Mississippian

Nevada: Moore, D. M. 00149

Ordovician

Norway: Goldschmidt, V. M. 00118

Scandinavia: Goldschmidt, V. M. 00116

\section{Geochemistry}

Abundance data

Alkali metals: Goldschmidt, V. M.00117

Alkali metals: Welby, C. W. 00334

Alum shale: Landergren, Sture. 00175

Antimony, arsenic: Onishi, Hiroshi. 00269

Antimony, bismuth, cadmium, germanium, indium, mercury, thallium: Preuss, E. 00257

Arsenic: Cadman, W. H. 00072

Arsenic, molybdenum: Onishi, Hiroshi. 00268

Arsenic, selenium: Moxon, A. L. 00239

Barium: Engelhardt, Wolf, 00044

Barium, chromium, copper, manganese, nickel, strontium, vanadium: Katchenkov, S. M. 00188

Barium, lithium, manganese, titanium: Clarke, F. W. 00058

Barium, lithium, manganese, titanium: Clarke, F. W. 00074

Beryllium: Goldschmidt, V. M. 00119

Beryllium isotopes: Merrill, J. R. 00148

Bituminous rocks: Leutwein, Friedrich. 00169
Geochemistry

A bundance data

Boron: Ernst, Werner. 00131

Boron: Goldschmidt, V. M. 00087

Boron: Goldschmidt, V. M. 00112

Boron: Harder, Hermann. 00099

Boron: Landergren, Sture. 00178

Boron: Vinogradov, A. P. 00345

Boron, molybdenum, nickel, vanadium: Couderc, J. M. 00076

Bromine, chlorine: Behne, Walter. 00028

Bromine, iodine: Itkina, E. S. 00222

Bromine, iodine: Itkina, E. S. 00223

Cadmium: Mullin, J. B. 00152

Cadmium: Tourtelot, H. A. 00282

Chlorine, fluorine: Correns, C. W. 00057

Chromium, cobalt, copper, manganese, nickel, vanadium: Pushkina, Z. V. 00259

Chromium, cobalt, copper, molybdenum, nickel, vanadium: Schröder, A. 00236

Chromium, cobalt, copper, nickel, vanadium: Strakhov, H. M. 00291

Chromium, cobalt, nickel, vanadium: Lundegárdh, P. H. 00167

Chromium, cobalt, nickel, zinc: Lundegàrdh, P. H. 00160

Chromium, gold, molybdenum, nickel, vanadium: Leutwein, Friedrich. 00138

Chromium, manganese, molybdenum, nickel, titanium, vanadium: Schneiderhöhn, $H$. 00235

Chromium, nickel, vanadium: Amirkhanov, Sh. Kh. 00023

Chromium, vanadium: Falke, Horst. 00126

Cobalt: Carr, M. H. 00065

Cobalt, chromium, molybdenum, nickel, tin, vanadium: Goldschmidt, V. M. 00086

Cobalt, copper, molybdenum, nickel, vanadium: Le Riche, H. H. 00137

Cobalt, copper, nickel, molybdenum, uranium, vanadium: Westergard; A. H. 00325

Cobalt, molybdenum, nickel, uranium, vanadium: Westergard, A. H. 00324

Cobalt, nickel: Savul, Mircea. 00234

Copper: Itkina, E. S. 00220

Copper: Itkina, E. S. 00221

Copper: Lombard, J. 00168

Copper, chromium, nickel, strontium, vanadium: Amirkhanov, Sh. Kh. 00022

Copper, gallium: vanadium: Goldschmidt, V. M. 00116

Copper, lead, manganese, nickel, titanium, vanadium: Engels, Bruno. 00403

Copper, lead, silver, vanadium: Allsman, P. T. 00020

Copper, molybdenum, nickel, vanadium: Bitterli, P. 00030

Copper, zinc; Barnes, H. L. 00026

Copper, zinc: Sugawara, Ken. 00276

Earth's crust: Clarke, F. W. 00058

Earth's crust: Green, Jack. 00090

Earth's crust: Green, Jack. 00109

Earth's crust: Turekian, K. K. 00354

Earth's crust: Vinogradov, A. P. 00349

Fjord sediment: Grant, G. M. 00089

Fjord sediment: Landergren, Sture. 00175

Fluorine: Koritnig, Sigmund. 00204 


\section{Geochemistry}

Abundance data

Gallium: Bell, C. K. 00029

Gallium: Borisenko, L. A. 00033

Gallium: Goldschmidt, V. M. 00118

Gallium: Vorob'ev, G. G. 0034 I

Gallium, germanium: Burton, J. D. 00070

Germanium: Goldschmidt, V. M. 00088

Germanium: Heide, F. 00404

Germanium: Lositskaya, I. F. 00142

Germanium: Onishi, Hiroshi. 00241

Germanium: Wardani, S. A. El. 00338

Germanium, uranium: Breger, I. A. 00037

Gold: Crouse, C. S. 00053

Gold: DeGrazia, A. R. 00049

Gold: Shcherbakov, YU. G. 00312

Gold: Varley, Thomas. 00347

Gold, iridium: Baedecker, P. A. 00007

Gold, silver: Goldschmidt, V. M. 00116

Gold, silver: Lindgren, Waldemar. 00140

Graphitic shale: Janda, I. 00219

Graphitic shale: Marmo, Vladi. 00146

Halogens: Correns, C. W. 00056

Indium: Shaw, D. M. 00308

Iodine: Chilean Iodine Educational Bureau. 00059

Iodine: Gulyayeva, L. A. 00093

Lanthanides, yttrium: Fleischer, Michael. 00124

Lead: Chow, T. J. 00066

Lead, uranium: Cobb, J. C. 00054

Lithium: Strock, L. W. 00292

Lithium, rubidium, cesium: Horstman, E. L. 00224

Manganese, molybdenum, nickel, titanium, vanadium: Blumer, Max. 00017

Manganese, molybdenum, uranium: Strahl, E. O. 00290

Manganese, strontium: Greensmith, J. T. 00091

Manganese, vanadium: Seidov, A. G. 00305

Mercury: Saukov, A. A. 00231

Mercury: Stock, Alfred. 00298

Minor elements: Barnett, P. R. 00011

Minor elements: Borchert, Herman. 00031

Minor elements: Brandenstein, M. 00038

Minor elements: Davidson, D. F. 00079

Minor elements: Davidson, D. F. 00081

Minor elements: Deans, T. 0005I

Minor elements: Głogoczowski, J. J. 00136

Minor elements: Gott, G. B. 00111

Minor elements: Harańczyk, C. 00096

Minor elements: Hirst, D. M. 00085

Minor elements: Katchenkov, S. M. 00181

Minor elements: Katchenkov, S. M. 00190

Minor elements: Katchenkov, S. M. 00191

Minor elements: Katchenkov, S. M. 00193

Minor elements: Katchenkov, S. M. 00215

Minor elements: Ketner, K. B. 00196

Minor elements: Konstantynowicz, E. 00198

Minor elements: Kontorovich, A. E. 00203

Minor elements: Krauskopf, K. B. 00210

Minor elements: K rejci-Graf, K arl. 00207

Minor elements: Landis, E. R. 00172

Minor elements: Landis, E. R. 00173
Geochemistry

A bundance data

Minor elements: Litvin, S. V.00141

Minor elements: Lotspeich, F. B. 00143

Minor elements: Love, J. D. 00144

Minor elements: Manheim, F. T. 00159

Minor elements: Maurel, P. 00147

Minor elements: Mohr, P. A. 00156

Minor elements: Morris, H. T. 00150

Minor elements: Murata, K. J. 00153

Minor elements: Nicholls, G. D. 00274

Minor elements: Noddack, Ida. 00239

Minor elements: Ostrom, M. E. 00243

Minor elements: Peltola, Esko. 00264

Minor elements: Prashnowsky, A. A. 00256

Minor elements: Pryakhina, YU. A. 00257

Minor elements: Pryakhina, YU. A. 00258

Minor elements: Rader, L. F. 00248

Minor elements: Rankama, Kalervo. 00255

Minor elements: Sahama, Th. G. 00229

Minor elements: Shaw, D. M. 00309

Minor elements: Tikhomirova, E. S. 00284

Minor elements: Tikhomirova, E. S. 00285

Minor elements: Tikhomirova, E. S. 00288

Minor elements: Tourtelot, H. A. 00283

Minor elements: Tourtelot, H. A. 00410

Minor elements: Ugolini, F. C. 00346

Minor elements: Vesterberg, K. Alb. 00409

Minor elements: Vine, J. D. 00348

Minor elements: Vinogradov, A. P. 00327

Minor elements: Weber, J. N. 00340

Minor elements: White, W. A. 00326

Minor elements: Zangerl, Rainer. 00318

Minor elements, precious metals, selenium: Tischendorf, Gerhard. 00278

Minor elements, uranium: Hyden, H. J. 00184

Minor elements, uranium: Klemic, Harry. 00205

Minor elements, uranium: Swanson, V. E. 00277

Molybdenum: Korolev, D. F. 00209

Molybdenum: Kuroda, P. K. 00200

Molybdenum, nickel, rare-earth elements, vanadium, zinc: Wells, R. C. 00323

Molybdenum, nickel, selenium, vanadium: Fischer, R. P. 00127

Molybdenum, tungsten, vanadium: Assarsson, G. O. 00005

Molybdenum, vanadium: Gamaleyev, I. E. 00125

Nickel: Pettersson, Hans. 00265

Nickel: Wells, R.C. 00322

Nickel, selenium, vanadium, zinc: Davidson, D. F. 00080

Nickel, titanium, vanadium: Koblic, Josef. 00198

Niobium: Rankama, Kalervo. 00254

Niobium, tantalum: Pachadzhanov, D. N. 00262

Ocean sediment: Glagoleva, M. A. 00135

Ocean sediment: Goldberg, E. D. 00114

Ocean sediment: Katchenkov, S. M. 00192

Ocean sediment: Landergren, Sture. 00175

Ocean sediment: Landergren, Sture. 00176

Ocean sediment: Seibold, Eugen. 00304 


\section{Geochemistry}

Abundance data

Ocean sediment: Wakeel, S. K. El. 00342

Ocean sediment: Young, E. J. 00317

Oil shale: Cadman, W. H. 00072

Oil shale: Fahey, J. J. 00132

Oil shate: Gil-av, E. 00120

Oil shale: Mustafa, Ahmed. 00272

Osmium, rhenium: Lovering, J. F. 00165

Platinum metals: Wright, T. L. 00316

Radioactive elements: Baranov, V. I. 00025

Radioactive elements: Breger, I. A. 00035

Radium, thorium, uranium: Zul'fugarly, N. D. 00319

Radium, uranium: Holland, H. D. 00183

Radium, uranium: Strutt, R. J. 00294

Radium, uranium, zinc: Landin, John. 00171

Rare-earth elements:

Borneman-Starynkevich, I. D. 00034

Rare-earth elements: Haskin, Larry. 00102

Rare-earth elements: Minami, E. 00180

Rare-earth elements: Ostroyumov, E. A. 00244

Rare-earth elements: Vinogradov, A. P. 00345

Rare-earth elements: Wildeman, T. R. 00314

Rubidium, cesium, thallium: Canney, F. C. 00064

Rubidium, strontium: Whitney, P. R. 00313

Scandium: Borisenko, L. F. 00032

Selenium: Ancizar-Sordo, Jorge. 00003

Selenium: Brimhall, W. H. 00069

Selenium: Byers, H. G. 00061

Selenium: Byers, H. G. 00062

Selenium: Byers, H. G. 00063

Selenium: Byers, H. G. 00071

Selenium: Chentsov, I. G. 00073

Selenium: Edgington, Glen. 00047

Selenium: Fleming, G. A. 00123

Selenium: Goldschmidt, V. M. 00110

Selenium: Lakin, H. W. 00179

Selenium: Lakin, H. W. 00201

Selenium: Lakin, H. W. 00202

Selenium: Leutwein, Friedrich. 00170

Selenium: Minami, E. 00155

Selenium: Moxon, A. L. 00154

Selenium: Moxon, A. L. 00238

Selenium: Sindeeva, N. D. 00302

Selenium: Walsh, T. 00343

Selenium: Williams, K. T. 00315

Selenium, uranium, vanadium: Gulbrandsen. R. A. 00108

Selenium, vanadium: Beath, O. A. 00013

Shungite: Marmo, Vladi. 00408

Silver: Crouse, C. S. 00053

Silver: Goldschmidt, V. M. 00115

Strontium: Noll, W. 00270

Strontium: Odum, H. T. 00240

Strontium: Turekian, K. K. 00351

Sulfide ore: Flek, Jindrich. 00122

Tantalum: Rankama, Kalervo. 00253

Thallium: Shaw, D. M. 00307

Thorium: Joly, John. 00186

\section{Geochemistry}

Abundance data

Thorium: Koczy, F. F. 00182

Thorium: Olson, J.C. 00267

Thorium, uranium: Baranov, V. I. 00009

Thorium, uranium: Bloxam, T. W. 00015

Thorium, uranium: Koczy, F. F. 00211

Thorium, uranium: Pliler, R. 00266

Thorium, uranium: Spears, D. A. 00299

Thorium, uranium, vanadium: Ponsford, D. R. A. 00247

Tin: Onishi, Hiroshi. 00242

Titanium, vanadium: Pallister, H. D. 00263

Uranium: Breger, I. A. 00039

Uranium: Conant, L. C. 00055

Uranium: Glover, Lynn. 00113

Uranium: Hecht, Friedrich. 00103

Uranium: Higazy, R. A. 00104

Uranium: Mapel, W. J. 00407

Uranium: Murty, P. S. N. 00271

Uranium: Ostrom, M. E. 00267

Uranium: Sheldon, R. P. 00301

Uranium: Skjeseth, Steinar. 00303

Uranium: Strøm, K. M.00293

Uranium: Wells, R.C. 00330

Uranium, minor elements: Kepferle, R. C. 00195

Uranium, vanadium: Mayzko, J. J. 00157

Vanadium: Allsman, P. T. 00021

Vanadium: Assarsson, G. 00006

Vanadium: Bøgvad, Richard. 00018

Vanadium: Eckschlagerová, Marcela. 00046

Vanadium: Jambor, J. L. 00218

Vanadium: Jost, Konrad. 00187

Vanadium: King, W. H. 00213

Vanadium: McKelvey, V. E. 00158

Vanadium: Ostroyumov, E. A. 00245

Vanadium: Rubey, W. W. 00226

Vanadium: Thorne, H. M. 00287

Zinc: Lundegårdh, P. H. 00162

Zinc: Wedepohl, K. H. 00337

Zirconium: Degenhardt, Heinz. 00082

Geochemical distribution

Arsenic: Rösler, H.J. 00225

Baltic Sea: Manheim, F. T. 00161

Barium: Joensuu, Oiva. 00185

Barium: Turekian, K. K. 00352

Beryllium: Warner, L. A. 00339

Boron: Harder, Hermann. 00100

Boron: Harder, Hermann. 00101

Boron: Spears, D. A. 00300

Cadmium, vanadium, zinc: Tourtelot, H. A. 00282

Cesium, lithium, rubidium: Horstman, E. L. 00224

Chromium: Fröhlich, F. 00134

Cobalt, copper, nickel: Ronov, A. B. 00252

Copper, halogens, nickel, vanadium:

Gulyayeva, L. A. 00094

Copper, lead, zinc: Kautzsch, Eberhard. 00217

Copper, lead, zinc: Konstantynowicz, E. 00198 
Geochemistry

Geochemical distribution

Copper, lead, zinc: Richter-Bernburg, Gerhard. 00251

Copper, lead, zinc: Savul, Mircea. 00233

Copper, lead, zinc: Schüller, Arno. 00237

Copper, lead, zinc: Steinbrecher, Bodo. 00297

Copper, lead, zinc: White, W. H. 00331

Copper, manganese, nickel, strontium, vanadium: Katchenkov, S. M. 00189

Copper, minor elements, uranium, vanadium: Tschanz, C. M. 00281

Copper, silver: Eisentraut, Otto. 00042

Fluorine: Koritnig, Sigmund. 00199

Germanium: Hallam, A. 00105

Germanium: Lositskaya, I. F. 00142

Germanium: Wardani, S. A. El. 00344

Gold: Leutwein, Friedrich. 00139

Gulf of Paria: Hirst, D. M. 00098

Heavy metals: Manheim, F. T. 00159

Indium: Shaw, D. M. 00308

Lead: Wedepohl, K. H. 00328

Manganese, vanadium: Seidov, A. G. 00305

Mercury: Saukov, A. A. 00231

Minor elements: Adyshev, M. M. 00002

Minor elements: Bidzhiyev, R. A. 00014

Minor elements: Cissarz, Arnold. 00068

Minor elements: Deul, Maurice. 00084

Minor elements: Ericson, D. B. 00044

Minor elements: Gulbrandsen, R. A. 00108

Minor elements: Janda, I. 00219

Minor elements: Katchenkov, S. M. 00182

Minor elements: Marmo, Vladi. 00408

Minor elements: Moore, D. M. 00149

Minor elements: Rankama, Kalervo. 00255

Minor elements: Richter, Gerhard. 00250

Minor elements: Shaw, D. M. 00309

Minor elements: Shaw, D. M. 00310

Minor elements: Tourtelot, H. A. 00279

Minor elements: Tourtelot, H. A. 00415

Minor elements: Trask, P. D. 00280

Minor elements: Wedepohl, K. H. 00329

Minor elements: Wedepohl, K. H. 00336

Molybdenum: Joensuu, Oiva. 00185

Molybdenum, vanadium: Razumnaya, E. G. 00249

Nickel, vanadium: Erdman, J. G. 00045

Ocean sediment: Aleksandrov, A. P. 00019

Ocean sediment: Glagoleva, M. A. 00121

Ocean sediment: Landergren, Sture. 00177

Ocean sediment: Seibold, Eugen. 00304

Ocean sediment: Turekian, K. K. 00350

Rare-earth elements: Balashov, Yu. A. 00024

Selenium: Lakin, H. W. 00201

Selenium: Sargent, J. D. 00230

Selenium, vanadium: Davidson, D. F. 00052

Syngenetic ore: Bain, G. W. 00008

Tantalum: Rankama, Kalervo. 00253

Thallium: Shaw, D. M. 00307

Thorium, uranium: Adams, J. A. S. 00001

Thorium, uranium: Koczy, F. F. 00211

Thorium, uranium: Koczy, F. F. 00406

Uranium: Bates, T. F. 00012

Uranium: Bates, T. F. 00027

\section{Geochemistry}

Geochemical distribution

Uranium: Fix, C. E. 00133

Uranium: Kochenov, A. V. 00405

Uranium: Larsson, Alf. 00174

Uranium: Rynninger, Roland. 00228

Vanadium: Ostroyumov, E. A. 00246

Vanadium: Savul, Mircea. 00232

Weathered zone: Lotspeich, F. B. 00143

Geochemical ratios

Copper:Lead:Zinc: Savul, Mircea. 00233

Minor elements: Moore, D. M. 00149

Nickel:Cobalt: Savul, Mircea. 00234

Niobium:titanium, tantalum:niobium:

Pachadzhanov, D. N. 00262

Rare-earth elements: Coryell, C. D. 00067

Rare-earth elements: Tugarinov, A. I. 00353

Rubidium, strontium: Campbell, F. A. 00060

Rubidium:cesium, zirconium:rubidium, cobalt:nickel: Nicholls, G. D. 00273

Strontium:calcium: Odum, H. T. 00240

Strontium calcium: Turekian, K. K. 00351

Thorium, uranium: Bloxam, T. W. 00015

Vanadium:Molybdenum: Seibold, Eugen. 00304

Vanadium:Nickel: Katchenkov, S. M. 00188

Geochemical relations

Carbonaceous rocks: Cloud, P. E., Jr. 00075

Copper: Harańczyk, C. 00097

England: Dunham, Kingsley. 00041

Japan: Kato, Iwao. 00216

Uranium: Grimbert, Arnold. 00092

Uranium: Grimbert, Arnold. 00107

Indicator elements

Barium, strontium, vanadium: Murray, H. H. 00402

Boron: Curtis, C. D. 00077

Boron: Ernst, Werner. 00128

Boron: Ernst, Werner. 00129

Boron: Ernst, Werner. 00131

Boron: Goldschmidt, V. M. 00112

Boron: Harder, Hermann. 00101

Boron: Porrenga, D. H. 00260

Boron: Spears, D. A. 00300

Boron, chromium, cobalt, copper, gallium, lead, nickel, vanadium, zinc: Potter, P. E. 00261

Boron, gallium, rubidium: Degens, E. T. 00048

Copper, halogens, nickel, vanadium: Gulyayeva, L. A. 00094

Gallium: Borisenko, L. A. 00033

Halogens: Gulyayeva, L. A. 00106

Minor elements: Degens, E. T. 00083

Minor elements: Degens, Egon. 00050

Minor elements: Keith, M. L. 00194

Strontium, calcium: Odum, H. T. 00240

Thorium, uranium: Adams, J. A. S. 00001

Source of the elements

Arsenic, copper: Rösler, H. J. 00225

Bituminous rocks: Blumer, Max. 00016

Boron: Harder, Hermann. 00100

Cadmium: Mullin, J. B. 00152

Chromium, cobalt, nickel, zinc: Lundegàrdh, P. H. 00160 


\section{Geochemistry}

Source of the elements

Cobalt, copper, nickel: Ronov, A. B. 00252

Copper: Kautzsch, Eberhard. 00217

Copper: White, W. S. 00320

Copper: White, W.S. 00321

Copper: White, W. S. 00332

Copper: White, W.S. 00333

Copper, lead, silver, zinc: Stanton, R. L. 00295

Copper, lead, zinc: White, W. H. 00331

Copper, uranium: Tschanz, C. M.00281

Copper, vanadium: Gunning, H. C. 00095

Germanium: Wardani, S. A. El. 00338

Heavy metals: Stanton, R. L. 00296

Lead: Chow, T. J. 00066

Lead: Wedepohl, K. H. 00328

Minor elements: Degens, Egon. 00050

Minor elements: Evans, W. D. 00130

Minor elements: Hirst. D. M. 00085

Minor elements: Keith, M. L. 00194

Minor elements: Krauskopf, K. B. 00210

Minor elements: Landergren, Sture. 00176

Minor elements: Leutwein, Friedrich. 00138

Molybdenum: Grant, G. M. 00089

Molybdenum, uranium, vanadium: Schuller, Arno. 00311

Nickel: Pettersson, Hans. 00265

Ocean sediment: Arrhenius, G. O. S. 00004

Ocean sediment: K rauskopf, K. B. 00206

Selenium: Lakin, H. W. 00179

Selenium: Tischendorf, Gerhard. 00278

Strontium, calcium: Odum, H.T. 00240

Sulfide ore: Dunham, Kingsley. 00041

Sulfide ore: Wedepohl, K. H. 00335

Syngenetic ore: Dunham, K. C. 00040

Syngenetic ore: Ekiert, Franciszek. 00043

Syngenetic ore: Love, L. G. 00145

Syngenetic ore: Love, L. G. 00163

Syngenetic ore: Love, L. G. 00164

Syngenetic ore: Lovering, T. S. 00166

Thorium uranium: Adams, J. A. S. 00001

Thorium, uranium: Spears, D. A. 00299

Uranium: Breger, I. A. 00036

Uranium: Breger, I. A. 00039

Uranium: Davidson, C. F. 00078

Uranium: Grimbert, Arnold. 00092

Uranium: Grimbert, Arnold. 00107

Uranium: Kita-Badak, M.00214

Uranium: Serikov, YU. I. 00306

Uranium: Sheldon, R. P. 00301

Uranium: Stadler, Gerhard. 00275

Uranium: Swanson, V. E. 00289

Uranium, vanadium: Muilenburg, G. A. 00151

Vanadium: Ostroyumov, E. A. 00245

\section{Germanium}

\section{Devonian}

Ohio, Tennessee: Breger, I. A. 00037

Geochemical abundance

England: Burton, J. D. 00070

Minnesota, Tennessee, Wisconsin: Wardani, S. A. El. 00344

Pacific Ocean: Wardani, S. A. El. 00338

Sedimentary rocks: Heide, F. 00404

Sedimentary rocks: Onishi, Hiroshi. 00241

\section{Germanium}

Jurassic

England: Hallam, A. 00105

Ordovician

Norway: Goldschmidt, V. M. 00088

Paleozoic

Europe: Goldschmidt, V. M. 00088

Russian SFSR, western: Lositskaya, I. F. 00142

\section{Germany}

Carboniferous

Barium, boron, chromium, copper, gallium, molybdenum, nickel, strontium, titanium, vanadium: Degens, Egon. 00050

Boron: Ernst, Werner. 00129

Devonian

Fluorine: Koritnig, Sigmund. 00204

Minor elements: Prashnowsky, A. A. 00256

Semiquantitative spectrographic analyses: Engels, Bruno. 00403

Geochemical abundances

Chlorine, fluorine: Correns, C. W. 00057

Chromium, manganese, molybdenum, nickel, titanium, vanadium: Schneiderhöhn, $H$. 00235

Halogens: Correns, C. W. 00056

Geochemical distribution

Selenium: Leutwein, Friedrich. 00170

Jurassic

Boron, molybdenum, nickel, vanadium: Couderc, J. M. 00076

Chromium, cobalt, copper, molybdenum, nickel, vanadium: Schröder, A. 00236

Fluorine: Koritnig, Sigmund. 00199

Fluorine: Koritnig, Sigmund. 00204

Liassic

Tantalum: Rankama, Kalervo. 00253

Ordovician

Fluorine: Koritnig, Sigmund. 00204

Paleozoic

Precious metals, selenium, spectrographic analyses: Tischendorf, Gerhard. 00278

Permian

Copper: White, W. S. 00321

Copper, lead, zinc: Kautzsch, Eberhard. 00217

Copper, lead, zinc: Schüller, Arno. 00237

Copper, lead, zinc: Steinbrecher, Bodo. 00297

Fluorine: Koritnig. Sigmund. 00204

Heavy metals: Ekiert, Franciszek. 00043

Minor elements: Cissarz, Arnold. 00068

Minor elements: Knitzschke, Gerhard. 00212

Minor elements: Noddack, Ida. 00239

Minor elements: Richter, Gerhard. 00250

Minor elements: Wedepohl, K. H.00329

Platinum metals: Wright, T. L. 00316

Selenium: Goldschmidt, V. M. 00110

Source of the elements: Schüller. Arno. 00311

Source of the elements: Trask, P. D. 00280

Spectrographic analyses: Noddack, Ida. 00239

Uranium: Bates, T. F. 00027

Tertiary

Boron: Ernst. Werner. 00131

Gold

Uranium: Stadler, Gerhard. 00275

Cretaceous

Kansas: Lindgren. Waldemar. 00140 
Goid

Devonian

Ken tucky: Crouse, C. S. 00053

Geochemical abundance

Atlantic Ocean, Pacific Ocean: Baedecker, P. A. 00007

Ocean sediment: Leutwein, Friedrich. 00169

Sedimentary rock: DeGrazia, A. R. 00049

Ocean sediment

Africa: Goldschmidt, V. M. 00116

Baltic Sea, North Sea: Leutwein, Friedrich. 00139

Ordovician

Scandinavia: Goldschmidt, V. M. 00116

Paleozoic

Union of Soviet Socialist Republics: Shcherbakov, YU. G. 00312

Pennsylvanian

Kansas: DeGrazia, A. R. 00049

Silurian

Thuringia: Leutwein, Friedrich. 00138

Thuringia: Leutwein, Friedrich. 00139

Tertiary

Utah, Wyoming: Varley, Thomas. 00347

Graphitic shale

Element abundance

Finland: Marmo, Vladi. 00146

Minor elements: Janda, 1.00219

Titanium, vanadium: Pallister, H. D. 00263

\section{Great Britain}

Carboniferous

Boron, uranium: Spears, D. A. 00300

Paleozoic

Thorium, uranium, vanadium: Ponsford, D. R. A. 00247

Silurian

Cesium, cobalt, nickel, rubidium, zirconium, ratios: Nicholls, G. D. 00273

\section{Gulf of Mexico}

Ocean sediment

Alkali metals: Welby, C. W. 00334

Gulf of Paria

Ocean sediment

Minor elements: Hirst, D. M. 00098

Halogens

Devonian

Russian SFSR, southern: Gulyayeva, L. A. 00106

Geochemical abundances

Sedimentary rock: Correns, C. W. 00056

Paleozoic

Union of Soviet Socialist Republics: Gulyayeva, L. A. 00094

Heavy metals

Geochemical origin

New Britain: Stanton, R. L. 00296

Ocean sediment: Arrhenius, G. O. S. 00004

Solomon Islands: Stanton, R. L. 00296

Permian

Idaho

Germany: Ekiert, Franciszek. 00043

Devonian(?) and Mississippian

Semiquantitative spectrographic analyses:

Davidson, D. F. 00081

Permian

Arsenic: Onishi, Hiroshi. 00268
Idaho

Permian

Barium, chromium, copper, manganese, nickel, strontium, vanadium, zinc:

Lotspeich, F. B. 00143

Molybdenum: Kuroda, P. K. 00200

Molybdenum, nickel, selenium, vanadium: Fischer, R. P. 00127

Nickel, selenium, vanadium, zinc: Davidson, D. F. 00080

Selenium, vanadium: Davidson, D. F. 00052

Uranium: Sheldon, R. P. 00301

Vanadium: McKelvey, V. E. 00158

Vanadium: Rubey, W. W. 00226

Illinois

Paleozoic

Minor elements: White, W. A. 00326

Uranium: Ostrom, M. E. 00267

Pennsylvanian

Barium, chromium, manganese, nickel, strontium, vanadium: Murray, H. H. 00402

Minor elements: Ostrom, M. E. 00243

Radioactive elements: Krumbein, W. C. 00208

India

Precambrian

Uranium: Murty, P.S. N. 00271

Indian Ocean

Geochemical abundance

Minor elements: Wakeel, S. K. El. 00342

Ocean sediment

Minor elements: Katchenkov, S. M. 00192

Indiana

Devonian

Semiquantitative spectrographic analyses:

Gott, G. B. 00111

Pennsylvanian

Barium, chromium, manganese, nickel,

strontium, vanadium: Murray, H. H. 00402

Minor elements: Zangerl, Rainer. 00318

Rare metals: Vine, J. D. 00348

Indium

Geochemical distribution

lodine

Sedimentary rocks: Shaw, D. M. 00308

Carboniferous

Russian SFSR, southern: Itkina, E. S. 00222

Devonian

Union of Soviet Socialist Republics: Gulyayeva, L. A. 00093

Geochemical abundance

Sedimentary rocks: Chilean Iodine Educational Bureau. 00059

Geochemical indicator

Sedimentary rocks: Gulyayeva, L. A. 00106

Paleozoic

Russian SFSR, southern: Itkina, E. S. 00223

Ireland

Carboniferous

Selenium: Fleming, G. A. 00123

Geochemical abundance

Selenium: Walsh, T. 00343

Iridium

Geochemical abundance

Atlantic Ocean, Pacific Ocean: Baedecker, P. A. 00007 


\section{BIBLIOGRAPHY OF MINOR ELEMENTS IN BLACK SHALES}

\section{Irish Sea}

Geochemical distribution

Cadmium: Mullin, J. B. 00152

Israel

Cretaceous

Uranium, semiquantitative spectrographic analyses: Gil-av, E., Heller, S. 00120

Japan

Geochemical abundances

Chlorine, fluorine: Correns, C. W. 00057

Mesozoic

Antimony: Onishi, Hiroshi. 00269

Arsenic: Onishi, Hiroshi. 00268

Barium: Engelhardt, Wolf. 00044

Copper, zinc: Sugawara, Ken. 00276

Germanium: Onishi. Hiroshi. 00241

Lead: Wedepohl, K. H. 00328

Lithium: Strock, L. W. 00292

Rare-earth elements: Minami, E. 00180

Selenium: Minami, E. 00155

Zinc: Wedepohl, K. H. 00337

Paleozoic

Antimony: Onishi, Hiroshi. 00269

Arsenic: Onishi, Hiroshi. 00268

Barium: Englehardt, Wolf. 00044

Copper, zinc: Sugawara, Ken. 00276

Germanium: Onishi, Hiroshi. 0024 I

Lead: Wedepohl, K. H. 00328

Lithium: Strock, L. W. 00292

Rare-earth elements: Minami, E. 00180

Selenium: Minami, E. 00155

Zinc: Wedepohl, K. H. 00337

Tertiary

Semiquantitative spectrographic analyses: Kato, Iwao. 00216

\section{Kabardin ASSR}

Jurassic

Kansas

Molybdenum: Korolev, D. F. 00209

Cretaceous

Gold, silver: Lindgren, Waldemar. 00140

Minor elements: Landis, E. R. 00172

Selenium: Byers, H. G. 00063

Uranium: Landis, E. R. 00172

Devonian, Mississippian

Semiquantitative spectrographic analyses, uranium: Landis, E. R. 00173

Pennsylvanian

Gold: DeGrazia, A. R. 00049

Qualitative spectrographic analyses: Runnels, R. T. 00227

Rare-earth elements: Haskin, Larry. 00102

Uranium: Bates, T. F. 00027

Uranium, semiquantitative spectrographic analyses: Hyden, H. J. 00184

\section{Kazakhstan}

Tertiary

Rare-earth elements: Tugarinov, A. I. 00353

\section{Kentucky}

Devonian

Gold, silver: Crouse, C. S. 00053

Pennsylvanian

Rare metals: Vine, J. D. 00348

Kupferschiefer

Element abundance

Boron: Harder, Hermann. 00099

\section{Kupferschiefer}

Element abundance

Chromium: Fröhlich, F. 00134

Lithium: Strock, L. W. 00292

Mercury: Stock, Alfred. 00298

Minor elements: Deans, T. 00051

Minor elements: Konstantynowicz, E. 00198

Minor elements: Noddack, Ida. 00239

Platinum metals: Wright, T. L. 00316

Selenium: Goldschmidt, V. M. 00110

Selenium: Leutwein, Friedrich. 00170

Silesia: Eisentraut, Otto. 00042

Silesia: Harańczyk, C. 00096

Tantalum: Rankama, Kalervo. 00253

Vanadium: Jost, Konrad. 00187

Geochemical distribution

Copper, lead, zinc: Richter-Bernburg, Gerhard.00251

Copper, lead, zinc: Schüller, Arno. 00237

Copper, lead, zinc: Steinbrecher, Bodo. 00297

England: Dunham, K. C. 00040

Minor elements: Cissarz, Arnold. 00068

Minor elements: Knitzschke, Gerbard. 00212

Minor elements: Richter, Gerhard. 00250

Minor elements: Trask, P. D. 00280

Minor elements: Wedepohl, K. H. 00329

Silesia: Harańczyk, C. 00097

Source of the elements

Copper: White, W. S. 00321

England: Hirst, D. M. 00085

Europe: Wedepohl, K. H. 00335

Germany: Ekiert, Franciszek. 00043

Minor elements: Richter, Gerhard. 00250

Minor elements: Schuiller, Arno. 00311

Sulfide ore: Kautzsch, Eberhard. 00217

Sulfide ore: Knight, C. L. 00197

Sulfide ore: Love, L. G. 00163

Lanthanides

Geochemical abundance

Sedimentary rocks: Fleischer, Michael. 00124

Lanthanum

Geochemical abundance

Ocean sediment: Young, E. J. 00317

Lead

Cambrian

Sweden: Cobb, J. C. 00054

Geochemical abundance

Ocean sediment: Chow, T. J. 00066

Ocean sediment: Ericson, D. B. 00044

Ocean sediment: Goldschmidt, V. M. 00116

Geochemical distribution

Ocean sediment: Turekian, K. K. 00350

Ocean sediment: White, W. H. 00331

Sedimentary rocks: Wedepohl, K. H. 00328

Geochemical indicator

Sedimentary rocks: Potter, P. E. 00261

Jurassic

Europe: Wedepohl, K. H. 00328

Ocean sediment

British Columbia: White, W. H. 00331

Paleogene

Rumania: Savul, Mircea, 00233

Paleozoic, lower

Sweden: Vesterberg, K. Alb. 00409

Permian

Europe: Deans, T. 00051 


\section{Lead}

Permian

Europe: Richter-Bernburg, Gerhard. 00251

Germany: Kautzsch, Eberhard. 00217

Germany: Schüller, Arno. 00237

Germany: Steinbrecher, Bodo. 00297

Silesia: Konstantynowicz, E. 00198

Wyoming: Allsman, P. T. 00020

Precambrian

Australia: Stanton, R. L. 00295

Minnesota: Cloud, P. E., Jr. 00075

\section{Lithium}

Geochemical abundance

Sedimentary rocks: Clarke, F. W. 00074

Sedimentary rocks: Horstman, E. L. 00224

Mesozoic

Japan: Strock, L. W. 00292

Paleozoic

Europe, Japan: Strock, L. W. 00292

\section{Manganese}

Cambrian

Siberia, southern: Pushkina, Z. V. 00259

Carboniferous

England: Greensmith, J. T.00091

Devonian

Union of Soviet Socialist Republics:

Katchenkov, S. M. 00189

Geochemical abundance

Germany: Schneiderhohn, H. 00235

Ocean sediment: Ericson, D. B. 00044

Sedimentary rocks: Clarke, F. W. 00074

Sedimentary rocks: Leutwein, Friedrich. 00169

Union of Soviet Socialist Republics: Tikhomirova, E. S. 00284

Geochemical distribution

Black Sea: Glagoleva, M. A. 00121

Black Sea: Glagoleva, M. A. 00135

Ocean sediment: Landergren, Sture. 00177

Ocean sediment

Pacific Ocean: Pettersson, Hans. 00265

Paleozoic

France, Sweden, United States: Strahl, E. O. 00290

Russian platform: Katchenkov, S. M. 00188

Paleozoic, lower

Sweden: Vesterberg, K. Alb. 00409

Pennsylvanian

Illinois, Indiana: Murray, H. H. 00402

Permian

Idaho: Lotspeich, F. B. 00143

Tertiary

Azerbaidzhan: Seidov, A. G. 00305

Triassic

British Columbia: Gunning, H. C. 00095

Switzerland: Blumer, Max. 00017

\section{Mediterranean Sea}

Geochemical abundance

Minor elements: Wakeel, S. K. El. 00342

Ocean sediment

Barium, molybdenum: Joensuu, Oiva, 00185

Uranium: Kochenov, A. V. 00405

Mercury

Geochemical distribution

Sedimentary rocks: Saukov, A. A. 00231
Mercury

Paleozoic

Europe: Stock, Alfred. 00298

Mexico

Mesozoic?

Copper, zinc: Barnes, H. L. 00026

\section{Michigan}

Precambrian

Copper: Barghoorn, E. S. 00010

Copper: White, W. S. 00320

Copper: White, W. S. 00321

Copper: White, W.S. 00332

Copper: White, W. S. 00333

Minnesota

Geochemical abundance

Germanium: Wardani, S. A. El. 00344

Ordovician

Antimony: Onishi, Hiroshi. 00269

Precambrian

Lead, uranium, vanadium: Cloud, P. E., Jr. 00075

Minor elements

Cambrian

Scandinavia: Bain, G. W. 00008

Tien-Shan: Adyshev, M. M. 00002

Wales: Mohr, P. A. 00156

Carboniferous

Appalachian coal basin: Degens, E. T. 00083

Germany: Degens, Egon. 00050

Ukrainian SSR: Litvin, S. V. 00141

Wales: Nicholls, G. D. 00274

Cenozoic

Siberia, western: Kontorovich, A. E. 00203 Clay

Union of Soviet Socialist Republics:

Katchenkov, S. M.00181

Cretaceous

Colorado, Kansas: Landis, E. R. 00172

Egypt: Mustafa, Ahmed. 00272

Israel: Gil-av, E., Heller, S. 00120

Montana, South Dakota. Wyoming:

Tourtelot, H. A. 00410

Nebraska, South Dakota: Kepferle, R. C. 00195

United States, western: Barnett, P. R. 00011

United States, western: Rader, L. F. 00248

United States, western: Tourtelot, H. A. 00279

United States, western: Tourtelot, H. A. 00283

United States, western: Tourtelot, H. A. 00415

Devonian

Germany: Engels, Bruno. 00403

Germany: Prashnowsky, A. A. 00256

Indiana, Texas: Gott, G. B. 0011]

New Hampshire: Shaw, D. M. 00309

Ohio, Tennessee: Breger, I. A. 00037

Tennessee, West Virginia: Klemic. Harry. 00205

Devonian. Mississippian

Arkansas: Swanson, V. E. 00277 
Minor elements

Devonian, Mississippian

Arkansas, Kansas, Missouri, Oklahoma:

Landis, E. R. 00173

Fjord sediment

British Columbia: Grant, G. M. 00089

Geochemical abundance

Atlantic Ocean, Indian Ocean, Mediterranean

Sea, Pacific Ocean: Wakeel, S. K. El. 00342

Austria: Brandenstein, M. 00038

Earth's crust: Turekian, K. K. 00354

Graphitic shale: Janda, I. 00219

Indian Ocean: Katchenkov, S. M. 00192

Pacific Ocean: Goldberg, E. D. 00114

Sea of Azov: Aleksandrov, A. P. 00019

Sedimentary rocks: Rankama, Kalervo. 00255

Sedimentary rocks: Vinogradov, A. P. 00349

Union of Soviet Socialist Republics:

Katchenkov, S. M. 00191

United States: Warner, L. A. 00339

Geochemical distribution

Clay, ocean sediment: Katchenkov, S. M. 00190

Europe: Borchert, Herman. 00031

Ocean sediment: Krauskopf, K. B. 00206

Sedimentary rocks: Deul, Maurice. 00084

Sedimentary rocks: Krauskopf, K. B. 00210

Sedimentary rocks: Rankama, Kalervo. 00255

Sedimentary rocks: Shaw, D. M. 00310

Union of Soviet Socialist Republics: Katchenkov, S. M. 00182

Union of Soviet Socialist Republics: Katchenkov, S. M. 00189

Geochemical indicators

Appalachian coal basin: Degens, E. T. 00083

Appalachian coal basin: Keith, M. L. 00194 Jurassic

France: Maurel, P. 00147

Union of Soviet Socialist Republics, west: Tikhomirova, E. S. 00285

Mesozoic

Albania: Katchenkov, S. M. 00193

Siberia, northern: Bidzhiyev, R. A. 00014

Siberia, western: Katchenkov, S. M. 00215

Siberia, western: Kontorovich, A. E. 00203

Mississippian

Missouri: Gott, G. B. 00111

Utah: Morris, H. T. 00150

Ocean sediment

Atlantic Ocean, Pacific Ocean: Wedepohl, K. H. 00336

Gulf of Paria: Hirst, D. M. 00098

Pacific Ocean: Murata, K. J. 00153

Ordovician

New York: Weber, J. N. 00340

Union of Soviet Socialist Republics, northwest: Tikhomirova, E. S. 00285

Paleozoic

Europe: Preuss, E. 00257

Germany: Tischendorf, Gerhard. 00278

Illinois: White, W. A. 00326

Nevada: Ketner, K. B. 00196

United States: Tourtelot, H. A. 00283

United States, western: Davidson, D. F. 00079

United States, western: Davidson, D. F. 00081

\section{Minor elements}

Pennsylvanian

Appalachian coal basin: Keith, M. L. 00194

Illinois: Ostrom, M. E. 00243

Indiana: Zangerl, Rainer. 00318

Indiana, Kentucky: Vine, J. D. 00348

Kansas: Runnels, R. T. 00227

Kansas, Missouri, Oklahoma: Hyden, H. J. 00184

Pennsylvanian and Permian

New Mexico: Tschanz, C. M. 00281

Permian

Germany: Cissarz, Arnold. 00068

Germany: Knitzschke, Gerhard. 00212

Germany: Noddack, Ida. 00239

Germany: Richter, Gerhard. 00250

Germany: Trask, P. D. 00280

Germany: Wedepohl, K. H. 00329

Silesia: Harańczyk, C. 00096

Wyoming: Gulbrandsen, R. A. 00108

Permian and Triassic

Alaska: Ugolini, F. C. 00346

Precambrian

Czechoslovakia: Flek, Jindrich. 00122

Finland: Peltola, Esko. 00264

Finland: Sahama, Th. G. 00229

Shungite: Marmo, Vladi. 00408

Tertiary

Albania: Katchenkov, S. M. 00193

Fore-Caucasus: Pryakhina, YU. A. 00257

Fore-Caucasus: Pryakhina, YU. A. 00258

Japan: Kato, Iwao. 00216

Poland: Głogoczowski, J. J. 00136

Wyoming: Fahey, J. J. 00132

Triassic

Pennsylvania: Klemic, Harry. 00205

Missouri

Devonian, Mississippian

Semiquantitative spectrographic analyses, uranium: Landis, E. R. 00173

Mississippian

Semiquantitative spectrographic analyses: Gott, G. B. 00111

Uranium, vanadium: Muilenburg, G. A. 00151

Pennsylvanian

Uranium, semiquantitative spectrographic analyses: Hyden, H. J. 00184

\section{Molybdenum}

Cambrian

Sweden: Wells, R. C. 00323

Sweden: Westergard, A. H. 00324

Sweden: Westergard, A. H. 00325

Cambrian and Ordovician

Sweden: Assarsson, G. O. 00005

Geochemical abundance

Adriatic Sea: Seibold, Eugen. 00304

Alaska, Arkansas, Idaho, Europe, Tasmania: Kuroda, P. K. 00200

Germany: Schneiderhöhn, H. 00235

Mediterranean Sea: Joensuu, Oiva. 00185

Rumania: Goldschmidt, V. M. 00086

Sedimentary rocks: Leutwein, Friedrich. 00169

Sedimentary rocks: Onishi, Hiroshi. 00268 


\section{Molybdenum}

Geochemical distribution

Sedimentary rocks: Kuroda, P. K. 00200

Union Soviet Socialist Republics: Razumnaya, E. G. 00249

Jurassic

England: Le Riche, H. H. 00137

Germany: Couderc, J. M. 00076

Germany: Schröder, A. 00236

Kabardin ASSR: Korolev, D. F. 00209

Saxony: Krejci-Graf, Karl. 00207

Switzerland: Bitterli, P. 00030

Paleozoic

France, Sweden, United States: Strahl, E. O. 00290

\section{Permian}

Europe: Deans, T. 00051

Idaho, Wyoming: Fischer, R. P. 00127

Silesia: Harańczyk, C. 00096

Wyoming: Love, J. D. 00144

Precambrian

Finland: Marmo, Vladi. 00146

\section{Silurian}

Thuringia: Leutwein, Friedrich. 00138

Uzbekistan: Gamaleyev, I. E. 00125

Triassic

Switzerland: Blumer, Max. 00017

\section{Mongolia}

Geochemical abundance

Gallium: Vorob'ev, G. G. 00341

\section{Montana}

Geochemical abundance

Uranium: Mapel, W. J. 00407

Paleozoic

Semiquantitative spectrographic analyses: Davidson, D. F. 00081

\section{Morocco}

Permian and Triassic

Copper: Lombard, J. 00168

\section{Nebraska}

Cretaceous

Semiquantitative spectrographic analyses, uranium: Kepferle, R. C. 00195

Nevada

Mississippian

Boron, cobalt, copper, gallium, nickel, scandium, vanadium: Moore, D. M. 00149 Paleozoic

Semiquantitative spectrographic analyses: Davidson, D. F. 00079

Semiquantitative spectrographic analyses: Davidson, D. F. 00081

Semiquantitative spectrographic analyses: Ketner, K. B. 00196

Paleozoic, lower

Nickel, selenium, vanadium, zinc: Davidson, D. F. 00080

New Britain

Ocean sediment

Heavy metals: Stanton, R. L. 00296

New Hampshire

Devonian

Spectrographic analyses: Shaw, D. M. 00309
New Mexico

Cretaceous

Selenium: Byers, H. G. 00063

Devonian

Copper, zinc: Barnes, H. L. 00026

Uranium: Bates, T. F. 00027

Pennsylvanian and Permian

Semiquantitative spectrographic analyses: Tschanz, C. M. 00281

Permian

Copper, uranium, vanadium: Gott, G. B. 00111

New York

Devonian

Arsenic: Onishi, Hiroshi. 00268

Rubidium, strontium: Whitney, P. R. 00313

Ordovician

Nickel

Minor elements: Weber, J. N. 00340

Cambrian

Siberia, southern: Pushkina, Z. V. 00259

Sweden: Wells, R. C. 00323

Sweden: Westergard, A. H. 00324

Sweden: Westergard, A. H. 00325

Carboniferous

Russian SFSR: Tikhomirova, E. S. 00288

Cretaceous

Uzbekistan: Amirkhanov, Sh. Kh. 00022

Uzbekistan: Amirkhanov, Sh. Kh. 00023

Devonian

Ohio, Tennessee: Breger, I. A. 00037

Russian platform: Strakhov, H. M. 00291

Union of Soviet Socialist Republics:

Katchenkov, S. M. 00189

Geochemical abundance

Adriatic Sea: Seibold, Eugen. 00304

Germany: Schneiderhöhn, H. 00235

Ocean sediment: Young, E. J. 00317

Rumania: Goldschmidt, V. M. 00086

Russian platform: Vinogradov, A. P. 00327

Sedimentary rocks: Leutwein, Friedrich. 00169

Sedimentary rocks: Wells, R. C. 00322

Sweden: Lundegảrdh, P. H. 00160

Union of Soviet Socialist Republics:

Tikhomirova, E. S. 00284

Geochemical distribution

Black Sea: Glagoleva, M. A. 00121

Black Sea: Glagoleva, M. A. 00135

Ocean sediment: Landergren, Sture. 00177

Ocean sediment: Turekian, K. K. 00350

Russian platform: Ronov, A. B. 00252

United States, Venezuela: Erdman, J. G. 00045

Geochemical indicator

Sedimentary rocks: Potter, P. E. 00261

Jurassic

England: Le Riche, H. H. 00137

Germany: Couderc, J. M. 00076

Germany: Schröder, A. 00236

Saxony: K rejci-Graf, Karl. 00207

Switzerland: Bitterli, P. 00030

Mississippian

Nevada: Moore, D. M. 00149

Ocean sediment

Pacific Ocean: Pettersson, Hans. 00265 


\section{Nickel}

Ordovician

Czechoslovakia: Koblic, Josef. 00198

Paleozoic

Idaho, Nevada, Utah, Wyoming: Davidson, D. F. 00080

Russian platform: Katchenkov, S. M. 00188

Union of Soviet Socialist Republics:

Gulyayeva, L. A. 00094

Paleozoic, lower

Sweden: Lundegårdh, P. H. 00167

Sweden: Vesterberg, K. Alb. 00409

Pennsylvanian

Illinois, Indiana: Murray, H. H. 00402

Permian

Europe: Deans, T. 00051

Idaho: Lotspeich, F. B. 00143

Idaho, Wyoming: Fischer, R. P. 00127

Silesia: Harańczyk, C. 00096

Wyoming: Love, J. D. 00144

Precambrian

Finland: Marmo, Vladi. 00146

Silurian

Thuringia: Leutwein, Friedrich. 00138

Tertiary

Poland: Głogoczowski, J. J. 00136

Triassic

Rumania: Savul, Mircea. 00234

Switzerland: Blumer, Max. 00017

\section{Niobium}

Carboniferous

Russian platform: Pachadzhanov, D. N. 00262

Devonian

Russian platform: Pachadzhanov, D. N. 00262

Geochemical distribution

Sedimentary rocks: Rankama, Kalervo. 00254

North America

Geochemical abundance

Rare-earth elements: Wildeman, T. R. 00314

North Dakota

Cretaceous

Selenium: Lakin, H. W. 00202

North Sea

Ocean sediment

Gold: Leutwein, Friedrich. 00139

\section{Norway}

Cambrian

Uranium: Skjeseth, Steinar. 00303

Uranium: Strøm, K. M. 00293

Fjord sediment

Uranium: Strøm, K. M. 00293

Ordovician

Beryllium: Goldschmidt, V. M.00119

Gallium: Goldschmidt, V. M. 00118

Germanium: Goldschmidt, V. M. 00088

Paleozoic

Boron: Goldschmidt, V. M. 00087

\section{Ocean sediment}

\section{Element abundance}

Adriatic Sea: Seibold, Eugen. 00304

Alkali metals: Welby, C. W. 00334

Barium: Turekian, K. K. 00352

\section{Ocean sediment}

Element abundance

Barium, boron, chromium, copper, lead, manganese, strontium, vanadium: Ericson, D. B. 00044

Beryllium: Merrill, J. R. 00148

Boron: Harder, Hermann. 00099

Boron, chromium, cobalt, manganese, nickel, titanium, vanadium: Landergren, Sture. 00177

Chromium: Fröhlich, F. 00134

Gallium, germanium: Burton, J. D. 00070

Gold: Leutwein, Friedrich. 00139

Gold: Leutwein, Friedrich. 00169

Gold, iridium: Baedecker, P. A. 00007

Gulf of Paria: Hirst, D. M. 00098

Indian Ocean: Katchenkov, S. M. 00192

Lead: Chow, T. J. 00066

Lead: Wedepohl, K. H. 00328

Minor elements: Goldberg, E. D. 00114

Minor elements: Katchenkov, S. M. 00181

Minor elements: Krauskopf, K. B. 00206

Minor elements: Landergren, Sture. 00175

Minor elements: Landergren, Sture. 00176

Minor elements: Murata, K. J. 00153

Nickel: Pettersson, Hans. 00265

Radioactive elements: Baranov, V. I. 00025

Rare-earth elements: Ostroyumov, E. A. 00244

Rare-earth elements: Wildeman, T. R. 00314

Sea of Azov: Aleksandrov, A. P. 00019

Selenium: Edgington, Glen. 00047

Silver: Goldschmidt, V. M. 00115

Thorium: Koczy, F. F. 00182

Uranium: Kochenov, A. V. 00405

Vanadium: Ostroyumov, E. A. 00245

Vanadium: Ostroyumov, E. A. 00246

Geochemical distribution

Barium, beryllium, chromium, copper, manganese, nickel, strontium, vanadium, zirconium: Katchenkov, S. M. 00190

Barium, chromium, cobalt, lanthanum, nickel, scandium, strontium, titanium, vanadium, zirconium: Young, E. J. 00317

Barium, molybdenum: Joensuu, Oiva, 00185

Cadmium: Mullin, J. B. 00152

Copper, lead, silver, uranium, zinc: Manheim, F.T. 00161

Copper, lead, zinc: White, W. H. 00331

Germanium: Wardani, S. A. El. 00338

Minor elements: Manheim, F. T.00159

Minor elements: Turekian, K. K. 00350

Minor elements: Wakeel, S. K. El. 00342

Minor elements: Wedepohl, K. H. 00336

Source of the elements

Heavy metals: Stanton, R. L. 00296

Heavy metals, rare-earth elements: Arrhenius, G. O.S. 00004

Ohio

Devonian

Radioactive elements: Breger, I. A. 00035

Semiquantitative spectrographic analyses: Breger, I. A. 00037

Uranium: Bates, T. F. 00027 
Oil shale

Cretaceous

Semiquantitative spectrographic analyses: Mustafa, Ahmed. 00272

\section{Devonian}

Gold, silver: Crouse, C. S. 00053

\section{Element abundance}

Antimony, arsenic: Onishi, Hiroshi. 00269

Arsenic, uranium, vanadium: Cadman, W. H. 00072

Beryllium: Warner, L. A. 00339

Egypt: Mustafa, Ahmed. 00272

Gold: Varley, Thomas. 00347

Israel: Gil-av, E.; Heller, S. 00120

Minor elements: Fahey, J. J. 00132

Minor elements: Krejci-Graf, Karl. 00207

Minor elements: Warner, L. A. 00339

Nickel, vanadium: Erdman, J. G. 00045

Uranium: Hecht, Friedrich. 00103

Uranium: Kita-Badak, M. 00214

Vanadium: Thorne, H. M. 00287

Tertiary

Gold: Varley, Thomas. 00347

\section{Okhotsk Sea}

Geochemical abundance

Vanadium: Ostroyumov, E. A. 00245

\section{Oklahoma}

Devonian, Mississippian

Semiquantitative spectrographic analyses, uranium: Landis, E. R. 00173

Pennsylvanian

Uranium, semiquantitative spectrographic analyses: Hyden, H. J. 00184

\section{Organic and mineral fractions}

Element abundance

Molybdenum, vanadium: Razumnaya, E. G. 00249

Element distribution

Minor elements: Deul, Maurice. 00084

Osmium

Uranium: Rynninger, Roland. 00228

Geochemical abundance

Australia: Lovering, J. F. 00165

\section{Pacific Ocean}

Geochemical abundance

Minor elements: Wakeel, S. K. El. 00342

Geochemical distribution

Minor elements: Landergren, Sture. 00176

Ocean sediment

Beryllium: Merrill, J. R. 00148

Germanium: Wardani, S. A. El. 00338

Gold, iridium: Baedecker, P. A. 00007

Manganese, nickel: Pettersson, Hans. 00265

Minor elements: Goldberg, E. D. 00114

Minor elements: Murata, K. J. 00153

Minor elements: Wedepohl, K. H. 00336

Radioactive elements: Baranov, V. I. 00025

Rare-earth elements: Wildeman, T. R. 00314

\section{Pennsylvania}

Devonian

Rubidium, strontium: Whitney, P. R. 00313

Paleozoic

Uranium: Bates, T. F. 00027
Pennsylvania

Triassic

Semiquantitative spectrographic analyses, uranium: Klemic, Harry. 00205

\section{Platinum metals}

Geochemical abundance

Sedimentary rocks: W right, T. L. 00316

Permian

Germany: Wright, T. L. 00316

Poland

Tertiary

Chromium, nickel, vanadium: Glogoczowski, J. J. 00136

Minor elements: Głogoczowski, J. J. 00136

\section{Precious metals}

Paleozoic

Germany: Tischendorf, Gerhard. 00278

\section{Radioactive elements}

Cretaceous

United States: Breger, I. A. 00035

\section{Devonian}

Ohio: Breger, I. A. 00035

Geochemical abundance

Pacific Ocean: Baranov, V. I. 00025

United States: Breger, I. A. 00035

Pennsylvanian

Illinois: Krumbein, W. C. 00208

Tertiary

California: Breger, I. A. 00035

\section{Radium}

Cambrian

Sweden: Landin, John. 00171

Sweden: Strutt, R. J. 00294

Geochemical abundance

Ocean sediment: Holland, H. D. 00183

Tertiary

Azerbaidzhan: Zul'fugarly, N. D. 00319

\section{Rare-earth elements}

\section{Cambrian}

Sweden: Wells, R.C. 00323

Geochemical abundance

Black Sea: Ostroyumov, E. A. 00244

North America: Wildeman, T. R. 00314

Pacific Ocean, Atlantic Ocean: Wildeman, T. R. 00314

Sedimentary rocks: Coryell, C. D. 00067

Union of Soviet Socialist Republics:

Vinogradov, A. P. 00345

Geochemical distribution

Ocean sediment: Arrhenius, G. O. S. 00004

Jurassic

Union of Soviet Socialist Republics:

Borneman-Starynkevich. I. D. 00034

Mesozoic

Japan: Minami, E. 00180

Paleozoic

Europe, Japan: Minami, E. 00180

Russian platform: Balashov, Yu. A. 00024

Pennsylvanian

Kansas: Haskin, Larry. 00102

Tertiary

Kazakhstan: Tugarinov, A. I. 00353 


\section{BIBLIOGRAPHY OF MINOR ELEMENTS IN BLACK SHALES}

Rhenium

Geochemical abundance

Australia: Lovering, J. F. 00165

Rubidium

Cretaceous

Alberta: Campbell, F. A. 00060

Devonian

Alberta: Campbell, F. A. 00060

Pennsylvania, New York: Whitney, P. R. 00313

Geochemical abundance

Sedimentary rocks: Canney, F. C. 00064

Sedimentary rocks: Horstman, E. L. 00224

Geochemical indicator

Sedimentary rocks: Degens, E. T. 00048

Silurian

Great Britain: Nicholls, G. D. 00273

Rumania

Cretaceous

Vanadium: Savul, Mircea. 00232

Geochemical distribution

Cobalt, chromium, molybdenum, nickel, tin, vanadium: Goldschmidt, V. M.00086

Paleogene

Copper, lead, zinc: Savul, Mircea. 00233

Triassic

Cobalt, nickel: Savul, Mircea. 00234

Russian platform

Carboniferous

Barium, chromium, copper, manganese, nickel, strontium, vanadium: Katchenkov, S. M. 00191

Niobium, tantalum: Pachadzhanov, D. N. 00262

Devonian

Barium, chromium, copper, manganese, nickel, strontium, vanadium: Katchenkov, S. M. 00191

Chromium, cobalt, copper, nickel, vanadium: Strakhov, H. M. 00291

Niobium, tantalum: Pachadzhanov, D. N. 00262

Geochemical abundance

Cobalt, copper, nickel, thorium, uranium: Vinogradov, A. P. 00327

Thorium, uranium: Baranov, V. I. 00009

Geochemical distribution

Cobalt, copper, nickel: Ronov, A. B. 00252

Paleozoic

Barium, chromium, copper, manganese, nickel, strontium, vanadium: Katchenkov, S. M. 00188

Rare-earth elements: Balashov, Yu. A. 00024

Russian SFSR

Carboniferous

Barium, beryllium, chromium, cobalt, copper, gallium, nickel, titanium, vanadium:

Tikhomirova, E. S. 00288

Russian SFSR, southern

Carboniferous

Bromine, iodine: Itkina, E. S. 00222

Copper: Itkina, E. S. 00221

Devonian

Halogens: Gulyayeva, L. A. 00106
Russian SFSR, southern

Paleozoic

Bromine, iodine: Itkina, E. S. 00223

Russian SFSR, western

Paleozoic

Germanium: Lositskaya, I. F. 00142

Saxony

Jurassic

Chromium, cobalt, molybdenum, nickel, vanadium: Krejci-Graf, Karl. 00207

Seandinavia

Cambrian

Minor elements: Bain, G. W. 00008

Silver: Goldschmidt, V. M. 00116

Ordovician

Gold, silver, gallium, vanadium:

Goldschmidt, V. M. 00116

Silurian and Ordovician

Thorium: Joly, John. 00186

\section{Scandium}

Geochemical abundance

Ocean sediment: Young, E. J. 00317

Sedimentary rocks: Borisenko, L. F. 00032

Mississippian

Nevada: Moore, D. M. 00149

Scotland

Oil shale

Arsenic: Cadman, W. H. 00072

Sea of Azov

Ocean sediment

Spectrographic analyses: Aleksandrov, A. P. 00019

\section{Selenium}

Abundance data

Sulfide ore: Goldschmidt, V. M. 00110

Carboniferous

Ireland: Fleming, G. A. 00123

Utah: Beath, O. A. 00013

Utah: Brimhall, W. H. 00069

Utah: Lakin, H. W. 00202

Cretaceous

California: Lakin, H. W. 00179

Canada: Williams, K. T. 00315

Canada, western: Byers, H. G. 00062

Colorado, Kansas, Montana, South Dakota: Byers, H. G. 00071

North Dakota: Lakin, H. W. 00202

South Dakota: Byers, H. G. 00061

South Dakota: Moxon, A. L. 00154

South Dakota: Moxon, A. L. 00238

United States, western: Byers, H. G. 00063

Wyoming: Beath, O. A. 00013

Geochemical abundance

Atlantic Ocean: Edgington, Glen. 00047

Columbia: Ancizar-Sordo, Jorge. 00003

Ireland: Walsh, T. 00343

United States, western: Byers, H. G. 00061

United States, western: Lakin, H. W. 00201

Geochemical distribution

Germany: Leutwein, Friedrich. 00170

United States: Sargent, J. D. 00230

Mesozoic

Japan: Minami, E. 00155

Paleozoic

Europe, Japan: Minami, E. 00155 
Selenium

Paleozoic

Germany: Tischendorf, Gerhard. 00278

Idaho, Nevada, Utah, Wyoming: Davidson, D. F. 00080

Permian

Germany: Goldschmidt, V. M. 00110

Idaho, Wyoming: Davidson, D. F. 00052

Idaho, Wyoming: Fischer, R. P. 00127

Wyoming: Beath, O.A. 00013

Wyoming: Gulbrandsen, R. A. 00108

Wyoming: Love, J. D. 00144

Silurian

Union of Soviet Socialist Republics, northwest: Sindeeva, N. D. 00302

Tertiary

A sia, central: Chentsov, I. G. 00073

\section{Shungite}

Element abundance

Minor elements: Marmo, Vladi. 00408

Siberia, northern

Mesozoic

Semiquantitative spectrographic analyses:

Bidzhiyev, R. A. 00014

Siberia, southern

Cambrian

Chromium, cobalt, copper, manganese, nickel, vanadium: Pushkina, Z. V. 00259

\section{Siberia, western}

Cenozoic

Minor elements: Kontorovich, A. E. 00203

Mesozoic

Minor elements: Katchenkov, S. M. 00215

Silesia

Minor elements: Kontorovich, A. E. 00203

Permian

Copper: Harańczyk, C. 00097

Copper, lead, zinc: Konstantynowicz, E. 00198

Copper, silver: Eisentraut, Otto. 00042

Silver

Minor elements: Harańczyk, C. 00096

Cretaceous

Kansas: Lindgren, Waldemar. 00140

Devonian

Kentucky: Crouse, C. S. 00053

Geochemical abundance

Ocean sediment: Goldschmidt, V. M. 00115

Ocean sediment

Africa: Goldschmidt, V. M. 00116

Paleozoic, lower

Scandinavia: Goldschmidt, V. M. 00116

Permian

Silesia: Eisentraut, Otto. 00042

Wyoming: Allsman, P. T. 00020

Precambrian

Australia: Stanton, R. L. 00295

Silurian

Thuringia: Leutwein, Friedrich. 00139

\section{Solomon Islands}

Ocean sediment

Heavy metals: Stanton, R. L. 00296

\section{South Dakota}

Cretaceous

Arsenic, selenium: Moxon, A. L. 00239

Selenium: Byers, H. G. 0006
South Dakota

Cretaceous

Selenium: Moxon, A. L. 00154

Selenium: Moxon, A. L. 00238

Semiquantitative spectrographic analyses, uranium: Kepferle, R. C. 00195

Pennsylvanian and Permian

Semiquantitative spectrographic analyses: Davidson, D. F. 00079

\section{Statistical sampling}

Geochemical distribution

Radioactive elements: Krumbein, W. C. 00208

Strontium

Carboniferous

England: Greensmith, J. T. 00091

\section{Cretaceous}

Alberta: Campbell, F. A. 00060

Uzbekistan: Amirkhanov, Sh. Kh. 00022

Devonian

Alberta: Campbell, F. A. 00060

Pennsylvania, New York: Whitney, P. R. 00313

Union of Soviet Socialist Republics: Katchenkov, S. M. 00189

Geochemical abundance

Europe: Noll, W. 00270

Ocean sediment: Ericson, D. B. 00044

Ocean sediment: Young, E. J. 00317

Sedimentary rocks: Odum, H. T. 00240

Sedimentary rocks: Turekian, K. K. 00351

Geochemical distribution

Black Sea: Glagoleva, M. A. 00121

Ocean sediment: Turekian, K. K. 00350

Paleozoic

Russian platform: Katchenkov, S. M. 00188

Pennsylvanian

Illinois, Indiana: Murray, H. H. 00402

Permian

Idaho: Lotspeich, F. B. 00143

Sulfide ore

Element abundance

Arsenic: Rösler, H. J. 00225

Geochemical distribution

Copper, uranium, vanadium: Tschanz, C. M. 00281

Copper, vanadium: Barghoorn, E. S. 00010

Germany: Knitzschke, Gerhard. 00212

Selenium: Goldschmidt, V. M.00110

\section{Jurassic}

England: Dunham, Kingsley. 00041

Source of the elements

Arsenic, copper: Rösler, H. J. 00225

Australia: Stanton, R. L. 00295

Copper: Kautzsch, Eberhard. 00217

Copper: Temple, K. L. 00286

Copper: White, W. S. 00320

Copper: White, W. S. 00321

Copper: White, W. S. 00332

Copper: White, W. S. 00333

Copper, zinc: Barnes, H. L. 00026

England: Dunham, Kingsley. 00041

Morocco: Lombard, J. 00168 


\section{BIBLIOGRAPHY OF MINOR ELEMENTS IN BLACK SHALES}

Sweden

Cambrian

Cobalt, copper, nickel, molybdenum, uranium, vanadium: Westergard, A. H. 00325

Cobalt, molybdenum, nickel, uranium, vanadium: Westergard, A. H. 00324

Lead, uranium: Cobb, J. C. 00054

Manganese, molybdenum, uranium: Strahl, E. O. 00290

Molybdenum, nickel, vanadium, rare-earth elements, zinc: Wells, R. C. 00323

Radium, uranium: Strutt, R. J. 00294

Radium, uranium, zinc: Landin, John. 0017

Uranium: Bates, T. F. 00027

Uranium: Davidson, C. F. 00078

Uranium: Larsson, Alf. 00174

Uranium: Rynninger, Roland. 00228

Uranium: Wells, R. C. 00330

Vanadium: Assarsson, G. 00006

Zinc: Lundegårdh, P. H. 00162

Cambrian and Ordovician

Molybdenum, tungsten, vanadium: Assarsson, G. O. 00005

Geochemical distribution

Boron: Landergren, Sture. 00178

Oil shale

Uranium, vanadium: Cadman, W. H. 00072 Ordovician

Zinc: Lundegårdh, P. H. 00162

Paleozoic

Chromium, cobalt, nickel, zinc: Lundegårdh, P. H. 00160

Paleozoic, lower

Chromium, cobalt, copper, lead, manganese, nickel, titanium, vanadium, zinc, zirconium: Vesterberg, K. Alb. 00409

Chromium, cobalt, nickel, vanadium:

Lundegàrdh, P. H. 00167

Thorium, uranium: Koczy, F. F. 00406

Precambrian

Chromium, cobalt, nickel, zinc: Lundegårdh, P. H. 00160

Zinc: Lundegårdh, P. H. 00162

\section{Switzerland}

Jurassic

Copper, molybdenum, nickel, vanadium: Bitterli, P. 00030

Triassic

Manganese, molybdenum, nickel, titanium, vanadium: Blumer, Max. 00017

Syngenetic ore

Permian

Europe: Wedepohl, K. H. 00335

Germany: Wedepohl, K. H. 00329

Precambrian

Australia: Love, L. G. 00164

Source of the elements

England: Dunham, K. C. 00040

England: Love, L. G. 00145

Heavy metals: Ekiert, Franciszek. 00043

Minor elements: Bain, G. W. 00008

Ocean sediment: Stanton, R. L. 00296

Sedimentary rocks: Knight, C. L. 00197

Sulfide ore: Lovering, T. S. 00166
Syngenetic ore

Source of the elements

Sulfide ore: Temple, K. L. 00286

\section{Tantalum}

Carboniferous

Russian platform: Pachadzhanov, D. N. 00262

Devonian

Russian platform: Pachadzhanov, D. N. 00262

Jurassic

Germany: Rankama, Kalervo. 00253

Paleozoic

Europe: Rankama, Kalervo. 00253

Tasmania

Permian

Antimony: Onishi, Hiroshi. 00269

Arsenic: Onishi, Hiroshi. 00268

Molybdenum: Kuroda, P. K. 00200

Tatar ASSR

Carboniferous

Barium, beryllium, chromium, copper, manganese, nickel, strontium, vanadium, zirconium: Katchenkov, S. M. 00190

Tennessee

Devonian

Beryllium, minor elements: Warner, L. A. 00339

Germanium: Wardani, S. A. El. 00344

Semiquantitative spectrographic analyses: Breger, I. A. 00037

Semiquantitative spectrographic analyses: Klemic, Harry. 00205

Uranium: Bates, T. F. 00027

Uranium: Breger, I. A. 00036

Uranium: Breger, I. A. 00039

Texas

Uranium: Conant, L. C. 00055

Devonian

Beryllium: Warner, L. A. 00339

Semiquantitative spectrographic analyses: Gott, G. B. 00111

Thallium

Geochemical abundance

Sedimentary rocks: Canney, F. C. 00064

Geochemical distribution

Sedimentary rocks: Shaw, D. M. 00307

Thorium

Cambrian

Great Britain: Ponsford, D. R. A. 00247

Carboniferous

England: Spears, D. A. 00299

Wales: Bloxam, T. W. 00015

Cretaceous

United States, southwestern: Pliler, R. 00266

Devonian

United States, southeastern: Olson, J. C 00267

Geochemical abundance

Ocean sediment: Koczy, F. F. 00182

Russian platform: Baranov, V. I. 00009

Russian platform: Vinogradov, A. P. 00327

Sedimentary rocks: Joly, John. 00186

United States: Adams, J. A. S. 00001 
Thorium

Geochemical distribution

Ocean sediment: Koczy, F. F. 00211

Paleozoic, lower

Sweden: Koczy, F. F. 00406

Silurian and Ordovician

Scandinavia: Joly, John. 00186

Tertiary

Azerbaidzhan: Zul'fugarly, N. D. 00319

\section{Thuringia}

Permian

Arsenic: Rösler, H. J. 00225

Silurian

Chromium, gold, molybdenum, nickel, vanadium: Leutwein, Friedrich. 00138

Gold, silver: Leutwein, Friedrich. 00139

\section{Tien-Shan}

Cambrian

Qualitative spectrographic analyses: Adyshev, M. M. 00002

Tin

Geochemical abundance

Rumania: Goldschmidt, V. M. 00086

Sedimentary rocks: Onishi, Hiroshi. 00242

Titanium

Carboniferous

Russian SFSR: Tikhomirova, E. S. 00288

Geochemical abundance

Germany: Schneiderhöhn, H. 00235

Ocean sediment: Landergren, Sture. 00177

Ocean sediment: Young, E. J. 00317

Sedimentary rocks: Clarke, F. W. 00074

Ordovician

Czechoslovakia: Koblic, Josef. 00198

Paleozoic, lower

Sweden: Vesterberg, K. Alb. 00409

Permian

Wyoming: Love, J. D. 00144

Precambrian

Alabama: Pallister, H. D. 00263

Triassic

British Columbia: Gunning, H. C. 00095

Switzerland: Blumer, Max. 00017

\section{Tungsten}

Cambrian and Ordovician

Sweden: Assarsson, G. O. 00005

\section{Ukrainian SSR}

Carboniferous

Minor elements: Litvin, S. V. 00141

\section{Union of Soviet Socialist Republics}

Clay

Minor elements: Katchenkov, S. M. 00181

Devonian

Copper, manganese, nickel, strontium, vanadium: Katchenkov, S. M. 00189

Iodine: Gulyayeva, L. A. 00093

Geochemical abundance

Minor elements: Katchenkov, S. M. 00191

Rare-earth elements: Vinogradov, A. P. 00345

Geochemical distribution

Distribution patterns: Katchenkov, S. M. 00182

Minor elements: Katchenkov, S. M. 00189
Union of Soviet Socialist Republics

Geochemical distribution

Molybdenum, vanadium: Razumnaya, E. G. 00249

Jurassic

Chromium, cobalt, copper, manganese, nickel, vanadium: Tikhomirova, E. S. 00284

Copper, manganese, molybdenum, nickel, silver, titanium: Tikhomirova, E. S. 00285

Rare-earth elements: Borneman-Starynkevich, I. D. 00034

Ordovician

Arsenic, copper, lead, manganese, molybdenum, nickel, silver, titanium: Tikhomirova, E. S. 00285

Chromium, cobalt, copper, manganese, nickel, vanadium: Tikhomirova, E. S. 00284

Paleozoic

Gold: Shcherbakov, YU. G. 00312

Halogens, copper, nickel, vandium: Gulyayeva, L. A. 00094

Silurian

Selenium: Sindeeva, N. D. 00302

United States

Cretaceous

Radioactive elements: Breger, I. A. 00035

Devonian

Manganese, molybdenum, uranium: Strahl, E. O. 00290

Eocene

Beryllium, minor elements: Warner, L. A. 00339

Geochemical distribution

Selenium: Sargent, J. D. 00230

Thorium, uranium: Adams, J. A. S. 00001

Uranium: Fix, C. E. 00133

Paleozoic

Semiquantitative spectrographic analyses:

Tourtelot, H. A. 00283

United States, eastern

Devonian

Uranium: Bates, T. F. 00012

United States, southeastern

Devonian

Thorium: Olson, J. C. 00267

Uranium: Glover, Lynn. 00113

United States, southwestern

Cretaceous

Thorium, uranium: Pliler, R. 00266

United States, western

Cretaceous

Cadmium, vanadium, zinc: Tourtelot, H. A. 00282

Minor elements: Rader, L. F. 00248

Minor elements: Tourtelot, H. A. 00279

Selenium: Byers, H. G. 00063

Selenium: Byers, H. G. 00071

Semiquantitative spectrographic analyses: Tourtelot, H. A. 00283

Semiquantitative spectrographic analyses: Tourtelot, H. A. 00410

Semiquantitative spectrographic analyses: Tourtelot, H. A. 00415 


\section{BIBLIOGRAPHY OF MINOR ELEMENTS IN BLACK SHALES}

\section{United States, western \\ Cretaceous}

Spectrographic analyses: Barnett, P. R. 00011

Geochemical abundance

Selenium: Byers, H. G. 00061

Selenium: Lakin, H. W. 00201

Paleozoic

Selenium, vanadium: Beath, O. A. 00013

Semiquantitative spectrographic analyses: Davidson, D. F. 00079

Semiquantitative spectrographic analyses: Davidson, D. F. 00081

\section{Uranium}

\section{Cambrian}

Norway: Skjeseth, Steinar. 00303

Norway: Strøm, K. M. 00293

Sweden: Cobb, J. C. 00054

Sweden: Davidson, C. F. 00078

Sweden: Landin, John, 00171

Sweden: Larsson, Alf. 00174

Sweden: Rynninger, Roland. 00228

Sweden: Strutt, R. J. 00294

Sweden: Wells, R. C. 00330

Sweden: Westergard, A. H. 00324

Sweden: Westergard, A. H. 00325

Carboniferous

England: Spears, D. A. 00299

France: Grimbert, Arnold. 00092

France: Grimbert, Arnold. 00107

Wales: Bloxam, T. W. 00015

Cretaceous

Colorado, Kansas: Landis, E. R. 00172

Egypt: Higazy, R. A. 00104

Israel: Gil-av, E.; Heller, S. 00120

Nebraska, South Dakota: Kepferle, R. C. 00195

United States, southwestern: Pliler, R. 00266

Devonian

Alabama, Georgia, Tennessee: Glover, Lynn. 00113

Ohio, Tennessee: Breger, I. A. 00037

Tennessee: Breger, I. A. 00036

Tennessee: Breger, I. A. 00039

Tennessee: Conant, L. C. 00055

United States, eastern: Bates, T. F. 00012

West Virginia: Klemic, Harry. 00205

Devonian, Mississippian

Arkansas: Swanson, V. E. 00277

Arkansas, Kansas, Missouri, Oklahoma: Landis, E. R. 00173

Fjord sediment

Norway: Strøm, K. M. 00293

Geochemical abundance

Black Sea, Mediterranean Sea: Kochenov, A. V. 00405

Idaho, Montana, North Dakota, Oregon, Utah: Mapel, W. J. 00407

Ocean sediment: Holland, H. D. 00183

Russian platform: Baranov, V. I. 00009

Russian platform: Vinogradov, A. P. 00327

United States: Adams, J. A. S. 00001

Geochemical distribution

Ocean sediment: Koczy, F. F. 00211
Uranium

Geochemical distribution

Sedimentary rocks: Swanson, V. E. 00289

United States: Fix, C. E. 00133

Mississippian

Alaska: Mayzko, J. J. 00157

Missouri: Muilenburg, G. A. 00151

Oil shale

Sweden: Cadman, W. H. 00072

Paleozoic

France, Germany, Sweden, Kansas, New Mexico, Ohio, Pennsylvania, Tennessee: Bates, T. F. 00027

France, Sweden, United States: Strahl, E. O. 00290

Great Britain: Ponsford, D. R. A. 00247

Illinois: Ostrom, M. E. 00267

Paleozoic, lower

Sweden: Koczy, F. F. 00406

Pennsylvanian

Kansas, Missouri, Oklahoma: Hyden, H. J. 00184

Permian

Idaho, Wyoming: Sheldon, R.P. 00301

New Mexico: Gott, G. B. 00111

Wyoming: Gulbrandsen, R. A. 00108

Precambrian

India: Murty, P. S. N. 00271

Minnesota: Cloud, P. E., Jr. 00075

Tertiary

Azerbaidzhan: Zul'fugarly, N. D. 00319

Carpathian Mountains: Kita-Badak, $M$. 00214

Fore-Caucasus: Serikov, YU. I. 00306

Germany: Stadler, Gerhard. 00275

Triassic

Austria: Hecht, Friedrich. 00103

Utah

Pennsylvania: Klemic, Harry. 00205

Carboniferous

Selenium: Beath, O. A. 00013

Selenium: Brimhall, W. H. 00069

Selenium: Lakin, H. W. 00202

Semiquantitative spectrographic analyses:

Davidson, D. F. 00081

Vanadium: King, W. H. 00213

Cretaceous

Selenium: Byers, H. G. 00063

Geochemical abundance

Uranium: Mapel, W. J. 00407

Mississippian

Molybdenum, nickel, selenium, vanadium:

Fischer, R. P. 00127

Nickel, selenium, vanadium, zinc: Davidson, D. F. 00080

Semiquantitative spectrographic analyses: Davidson, D. F. 00079

Semiquantitative spectrographic analyses: Morris, H. T. 00150

Tertiary

Gold: Varley, Thomas. 00347

\section{Uzbekistan}

Cretaceous

Chromium, nickel, vanadium: Amirkhanov, Sh. Kh. 00023 


\section{Uzbekistan}

Cretaceous

Copper, chromium, nickel, strontium, vanadium: Amirkhanov, Sh. Kh. 00022

Silurian

Molybdenum, vanadium: Gamaleyev, I. E. 00125

Vanadium

Cambrian

Siberia, southern: Pushkina, Z. V. 00259

Sweden: Assarsson, G. 00006

Sweden: Wells, R. C. 00323

Sweden: Westergard, A. H. 00324

Sweden: Westergard, A. H. 00325

Cambrian and Ordovician

Sweden: Assarsson, G. O. 00005

Carboniferous

Russian SFSR: Tikhomirova, E. S. 00288

Utah: King, W. H. 00213

Cretaceous

Rumania: Savul, Mircea. 00232

United States, western: Tourtelot, H. A. 00282

Uzbekistan: Amirkhanov, Sh. Kh. 00022

Uzbekistan: Amirkhanov, Sh. Kh. 00023

Devonian

Ohio, Tennessee: Breger, I. A. 00037

Russian platform: Strakhov, H. M. 00291

Union of Soviet Socialist Republics: Katchenkov, S. M. 00189

Geochemical abundance

Adriatic Sea: Seibold, Eugen. 00304

Black Sea: Ostroyumov, E. A. 00246

Europe: Jost, Konrad. 00187

Germany: Schneiderhöhn, H. 00235

Ocean sediment: Ericson, D. B. 00044

Ocean sediment: Landergren, Sture. 00177

Ocean sediment: Young, E. J. 00317

Okhotsk Sea: Ostroyumov, E. A. 00245

Rumania, : Goldschmidt, V. M. 00086

Sedimentary rocks: Jost, Konrad. 00187

Sedimentary rocks: Leutwein, Friedrich. 00169

Union of Soviet Socialist Republics: Tikhomirova, E. S. 00284

Geochemical distribution

Black Sea: Glagoleva, M. A. 00121

Black Sea: Glagoleva, M. A. 00135

Denmark: Bøgvad, Richard. 00018

Union Soviet Socialist Republics: Razumnaya, E. G. 00249

United States, Venezuela: Erdman, J. G. 00045

Geochemical indicator

Sedimentary rocks: Potter, P. E. 00261

Jurassic

England: Le Riche, H. H. 00137

Germany: Couderc, J. M. 00076

Germany: Schröder, A. 00236

Saxony: Krejci-Graf, Karl. 00207

Switzerland: Bitterli, P. 00030

Mississippian

Alaska: Mayzko, J. J. 00157

Missouri: Muilenburg, G. A. 00151

Nevada: Moore, D. M. 00149

\section{Vanadium}

Mississippian, Permian

Idaho, Wyoming, Utah: Fischer, R. P. 00127

Oil shale

Sweden: Cadman, W. H. 00072

Ordovician

Czechoslovakia: Koblic, Josef. 00198

Scandinavia: Goldschmidt, V. M. 00116

Paleozoic

Great Britain: Ponsford, D. R. A. 00247

Idaho, Nevada, Utah, Wyoming: Davidson, D. F. 00080

Russian platform: Katchenkov, S. M. 00188

Union of Soviet Socialist Republics: Gulyayeva, L. A. 00094

Paleozoic, lower

Sweden: Lundegårdh, P. H. 00167

Sweden: Vesterberg, K. Alb. 00409

Pennsylvanian

Illinois, Indiana: Murray, H. H. 00402

Permian

Europe: Deans, T. 00051

France: Falke, Horst. 00126

Idaho: Lotspeich, F. B. 00143

Idaho: McKelvey, V. E. 00158

Idaho, Wyoming: Davidson, D. F. 00052

Idaho, Wyoming: Rubey, W. W. 00226

New Mexico: Gott, G. B. 00111

Silesia: Harańczyk, C. 00096

Wyoming: Allsman, P. T. 00020

Wyoming: Allsman, P. T. 00021

Wyoming: Beath, O. A. 00013

Wyoming: Gulbrandsen, R. A. 00108

Wyoming: Love, J. D. 00144

Precambrian

Alabama: Pallister, H. D. 00263

Finland: Marmo, Vladi. 00146

Minnesota: Cloud, P. E., Jr. 00075

Silurian

Czechoslovakia: Eckschlagerová, Marcela. 00046

Thuringia: Leutwein, Friedrich, 00138

Uzbekistan: Gamaleyev, I. E. 00125

Tertiary

Azerbaidzhan: Seidov, A. G. 00305

Colorado: Thorne, H. M. 00287

Czechoslovakia: Eckschlagerová, Marcela. 00046

Poland: Głogoczowski, J. J. 00136

Triassic

British Columbia: Gunning, H. C. 00095

British Columbia: Jambor, J. L. 00218

Switzerland: Blumer, Max. 00017

Venezuela

Cretaceous

Nickel, vanadium: Erdman, J. G. 00045

Wales

Cambrian

Minor elements: Mohr, P. A. 00156

Carboniferous

Minor elements: Nicholls, G. D. 00274

Thorium, uranium: Bloxam, T. W. 00015 


\section{BIBLIOGRAPHY OF MINOR ELEMENTS IN BLACK SHALES}

\section{West Virginia}

Devonian

Semiquantitative spectrographic analyses, uranium: Klemic, Harry. 00205

\section{Wisconsin}

Geochemical abundance

Germanium: Wardani, S. A. El. 00344

Ordovician

Copper, zinc: Barnes, H. L. 00026

\section{Wyoming}

Cretaceous

Selenium: Beath, O. A. 00013

\section{Permian}

Cadmium, chromium, molybdenum, nickel, selenium, titanium, vanadium, zinc: Love, J. D. 00144

Copper, lead, silver, vanadium: Allsman, P. T. 00020

Molybdenum, nickel, selenium, vanadium: Fischer, R. P. 00127

Nickel, selenium, vanadium, zinc: Davidson, D. F. 00080

Selenium, vanadium: Beath, O. A. 00013

Selenium, vanadium: Davidson, D. F 00052

Selenium, vanadium, uranium: Gulbrandsen, R. A. 00108

Semiquantitative spectrographic analyses: Davidson, D. F. 00079

Uranium: Sheldon, R. P. 00301

Vanadium: Allsman, P. T. 00021

Vanadium: Rubey, W. W. 00226

Tertiary

Gold: Varley, Thomas. 00347

Minor elements: Fahey, J. J. 00132

\section{Yttrium}

Geochemical abundance

Sedimentary rocks: Fleischer, Michael. 00124

Zinc

Cambrian

Sweden: Landin, John. 00171

Sweden: Lundegårdh, P. H. 00162

Sweden: Wells, R. C. 00323

Cretaceous

United States, western: Tourtelot, H. A. 00282

Devonian

New Mexico: Barnes, H. L. 00026

Geochemical abundance

Sedimentary rocks: Sugawara, Ken. 00276

Sweden: Lundegärdh. P. H. 00160

Geochemical indicator

Sedimentary rocks: Potter, P. E. 00261

Mesozoic

Europe, Japan: Wedepohl, K. H. 00337

Mexico: Barnes, H. L. 00026

Ocean sediment

British Colum bia: White, W. H. 00331

\section{Ordovician}

Sweden: Lundegårdh, P. H. 00162

Wisconsin: Barnes, H. L. 00026

Paleogene

Rumania: Savul, Mircea. 00233

Paleozoic

Europe, Japan: Wedepohl, K. H. 00337
Zinc

Paleozoic

Idaho, Nevada, Utah, Wyoming: Davidson,

D. F. 00080

Paleozoic, lower

Sweden: Vesterberg, K. Alb. 00409

Permian

Europe: Deans, T. 00051

Europe: Richter-Bernburg, Gerhard. 00251

Germany: Kautzsch, Eberhard. 00217

Germany: Schüller, Arno. 00237

Germany: Steinbrecher, Bodo. 00297

Idaho: Lotspeich, F. B. 00143

Silesia: Konstantynowicz, E. 00198

Wyoming: Love, J. D. 00144

\section{Precambrian}

Australia: Stanton, R. L. 00295

Finland: Marmo, Vladi. 00146

Sweden: Lundegårdh, P. H. 00162

\section{Zirconium}

Geochemical abundance

Ocean sediment: Young, E. J. 00317

Sedimentary rocks: Degenhardt, Heinz. 00082

Jurassic

Europe: Degenhardt, Heinz. 00082

Paleozoic

Europe: Degenhardt, Heinz. 00082

Paleozoic, lower

Sweden: Vesterberg, K. Alb. 00409 


